\title{
O AGENTE PENITENCIÁRIO AOS OLHOS DO JUDICIÁRIO PAULISTA
}

Dissertação de Mestrado

Orientador: Professor Associado Alvino Augusto de Sá

Faculdade de Direito da Universidade de São Paulo 


\section{VIVIAN CALDERONI}

\section{O AGENTE PENITENCIÁRIO AOS OLHOS DO JUDICIÁRIO PAULISTA}

Dissertação apresentada à Banca Examinadora da Faculdade de Direito da Universidade de São Paulo, como exigência parcial para obtenção do título de Mestre na área de concentração: Direito Penal, Medicina Forense e Criminologia, sob a orientação do Professor Associado Alvino Augusto de Sá

Faculdade de Direito da Universidade de São Paulo 


\section{O AGENTE PENITENCIÁRIO \\ AOS OLHOS DO JUDICIÁRIO PAULISTA}

VIVIAN CALDERONI

DATA:

BANCA EXAMINADORA:

$1^{\circ}$ Examinador

Orientador: Professor Associado Alvino Augusto de Sá

$2^{\circ}$ Examinador(a)

$3^{\circ}$ Examinador(a) 
Aos meus avós, לעילוי נשמת - in memoriam Luisa $^{\mathrm{zl}}$ e Moisés ${ }^{\mathrm{zl}}$; Ester ${ }^{\mathrm{zl}}$ e Nathan ${ }^{\mathrm{zl}}$ 


\section{AGRADECIMENTOS}

Ao Professor Doutor Alvino Augusto de Sá, meu orientador, por ter sempre acreditado no meu potencial como pesquisadora e ter me auxiliado, de modo generoso e presente, a transformar um projeto em realidade. Agradeço especialmente por toda sua doação durante o processo de construção desta dissertação. Por sua leitura atenta e aos seus comentários precisos. Sua experiência, seu conhecimento e seu pioneirismo são inspiradores.

Ao Professor Titular Sérgio Salomão Shecaira e ao Professor Doutor Marcus Orione por suas lições transformadoras e por terem feito do meu exame de qualificação um inestimável momento de compartilhamento e desenvolvimento.

Aos meus mestres, Professora Doutora Ana Lucia Pastore Schritzmeyer, Professor Doutor Fernando Salla e Professor Doutor Marcos César Alvarez, com muito carinho, por me ajudarem a desenvolver a curiosidade científica alinhada com o rigor metodológico.

Aos Prezados Magistrados, a quem entrevistei, que acreditaram na relevância desta pesquisa e, com generosidade, me concederam a oportunidade de realizá-la.

À Professora Doutora Ana Elisa Bechara, pelo auxílio na construção de um instrumental de coleta de dados e de um projeto de pesquisa que respeitasse os limites éticos.

À Dra. Fernanda Afonso, pelo carinhoso e fundamental apoio que me deu na fase final da construção desta dissertação.

A Dalva Veramundo Bizerra de Souza, Secretária do Departamento de Direito Penal, Medicina Forense e Criminologia, e a Marcela Moreira de Oliveira, técnica acadêmica do mesmo departamento, por todo suporte ao longo dessa caminhada.

Aos amigos da Conectas Direitos Humanos, por compartilharem a crença de que um mundo mais justo é possível e por me propiciarem um cotidiano pleno de aprendizado.

A Vanessa Faullame, pelo afetuoso olhar sempre atento aos meus escritos. 
Aos queridos Norton Thomé Zardo e Bruno Amábile Bracco, grandes amigos que me apoiaram incondicionalmente no desenvolvimento desta dissertação e ainda me auxiliaram na busca de dados fundamentais. A Flávia Annenberg, por todo apoio, suporte e comentários ao texto original.

Aos presos e acadêmicos companheiros dos encontros de diálogo em unidades prisionais no desenvolvimento do trabalho do Grupo de Diálogo Universidade Cárcere ComunidadeGDUCC, durante os anos de 2010, 2011 e 2012, por compartilharem suas experiências de vida que me transformaram a cada encontro.

Aos meus colegas de pós-graduação, Adriana Britto, Ana Gabriela Braga, Bruno Shimizu, Maria Emília Bretan, Jorge Chade, Jovacy Peter Filho, por terem compartilhado um caminhar permeado por tropeços e conquistas. E, em especial, a Bruno Amábile Bracco e a Luis Carlos Valois, pela leitura crítica dos originais desta dissertação, pelas conversas de amigos, pelas viagens e pelo extraordinário aprendizado que o convívio com eles me proporciona.

Às minhas queridas Amanda Oi, Aninha Blaser, Bruna Angotti, Caroline Landau, Gorete Marques e Muriel Soares, pelas conversas e discussões sobre esta e muitas outras pesquisas, projetos, planos, sonhos...

À minha querida família.

Ao meu irmão Ricardo, pelos cuidados e por acrescentar a arte em meu cotidiano com suas belíssimas melodias.

Com todo meu amor, à minha mãe, Sila, e ao meu pai, Sabetai, grandes exemplos de pessoas que norteiam suas vidas pessoal e profissional em prol da coletividade. Pelo apoio incondicional e compreensão infinita. Pela revisão mais do que atenta dos originais e pelas ponderações e discussões sobre os dados coletados. Mas, muito mais importante, pelas reflexões sobre planos e projetos de vida.

Ao Sami, por toda paciência, compreensão, companheirismo, e, principalmente, por me demostrar, cotidianamente, o verdadeiro significado da expressão “amor ao próximo”. 
CALDERONI, Vivian. O Agente Penitenciário aos Olhos do Judiciário Paulista. 2012. 246 f. Dissertação (Mestrado em Criminologia). Departamento de Direito Penal, Medicina Forense e Criminologia da Faculdade de Direito da Universidade de São Paulo.

RESUMO

O objetivo do presente trabalho consistiu na identificação de elementos valorativos e perceptivos que o Poder Judiciário tem em relação ao agente de segurança penitenciária (ASP), discriminando temas, ênfases e tendências. Para a sua consecução, foram realizadas oito entrevistas semidirigidas com juízes atuantes em Varas de Execução Criminal do Estado de São Paulo. A apresentação do estado da arte demonstrou a pluralidade de ângulos sob os quais a temática relativa aos agentes penitenciários vem sendo estudada. $\mathrm{O}$ levantamento bibliográfico revelou ser escassa a literatura sobre a percepção do Poder Judiciário acerca dos ASPs. Foram criadas, a partir das entrevistas realizadas, dez categorias de análise: preparo, papel e formas de atuação do ASP; relacionamento entre os ASPs e o Poder Judiciário; relacionamento entre ASP e preso; relacionamento entre ASP e a direção da unidade prisional em que trabalham; probidade dos ASPs; vulnerabilidade e segurança do ASP no exercício da sua profissão; valorização, por parte do Poder Judiciário, do depoimento do ASP; condições de trabalho do ASP; fatores emocionais relacionados ao trabalho do ASP; impacto do crime organizado na atuação do ASP. Da apresentação e análise dos dados resultaram 18 súmulas analítico-descritivas. No capítulo destinado às conclusões, foram apresentadas as principais contribuições desta pesquisa, as quais consistiram na identificação dos principais temas que premeiam a visão do Judiciário sobre os ASPs e dentro deles as tendências e as ênfases prevalecentes. Estes temas foram agrupados em cinco linhas perceptivas: função do ASP: ressocializadora vs. disciplinar ênfase sobre a valorização da ressocialização; poder do ASP - tendência dos juízes em respaldar o ASP para aumentar seu poder e ênfase no rearranjo no equilíbrio de poder em face da atuação das facções criminosas; influência da facção criminosa no trabalho do ASP - ênfase sobre o atentado à probidade do agente e ao aumento de vulnerabilidade dos ASPs; impactos psicossociais do trabalho do ASP - ênfase no adoecimento decorrente da prática profissional e no processo de prisionalização; e contexto de atuação do ASP ênfase na insalubridade e nos aspectos relativos à carreira do ASP. A seguir, é apresentado um conjunto de reflexões críticas com base nos resultados da pesquisa, na análise da literatura estudada e em diálogo com as vivências profissionais da pesquisadora. Em seguida, foram sugeridos temas para novas pesquisas e, por fim, propostas de interação envolvendo os principais especialistas e atores no processo de execução penal.

Palavras-chave: Agentes Penitenciários - percepção do Judiciário - Poder Judiciário Administração Penitenciária - prisões - Vara de Execução Criminal. 


\begin{abstract}
The Penitentiary Correctional Officers in the Eyes of the Judiciary of the State of São Paulo

The objective of this work is to identify the perceptions and value attributed to Penitentiary Correctional Officers (PCOs) by the Judiciary, pointing out themes, emphases, and trends. This work was accomplished through eight semi-directed interviews conducted with judges active in the Criminal Court on the Enforcement of Sentences of the State of Sao Paulo. The execution of this work has demonstrated the wide array of ways in which correctional officers are studied. The bibliographical search has revealed a scarcity of literature referring to the Judiciary's perception of the PCOs. Ten categories of analysis emerged from the interviews conducted: the preparation, role and work of the PCOs; the relationship between the PCOs and the Judiciary; the relationship between the PCO and the incarcerated; the relationship between the PCOs and the management of the prison unit in which they work; probity of the PCOs; vulnerability and security of the PCOs in the workplace; credit of the PCOs testament, as perceived by the Judiciary; work conditions of the PCOs; emotional factors related to the work of the PCOs; and the impact of organized crime in the work of the PCOs. The presentation and analysis of the data resulted in 18 descriptive-analytic summaries. The concluding chapter presents the main contributions of this research, consisting in the identification of the main themes that inform the vision of the Judiciary regarding PCOs and its prevailing emphases and trends. These themes were grouped into five lines of thought: the function of the PCO: resocializing vs. disciplinary emphasis on the value of resocialization: the power of the PCO - the tendency of the judges in supporting PCOs to increase their power and the emphasis in the rearrangement of the balance of power vis-a-vis criminal factions; the influence of the criminal faction in the work of the PCO -- emphasis on the attempts to discredit PCOs and increasing vulnerability of the PCOs; psycho-social impact of the work of the PCO - emphasis on illness associated with the work and imprisonment; and context of the work of the PCO emphasis on the unhealthfulness relative to the career of the PCO. Next follow critical reflections based on research results, the analysis of the literature review, and in dialogue with the professional experiences of the researcher. Following that is a presentation of themes for future research and, finally, a proposal for the evolving interaction of the primary specialists and actors in the process of penal execution.
\end{abstract}

Keywords: Penitentiary Correctional Officers (PCOs) - the perception of the Judiciary Judicial Power - Penitentiary administration - Prisons - Criminal Court on the Enforcement of Sentences 
APRESENTAÇÃO................................................................................................................. 12

CAPÍTULO 1 - EM BUSCA DO OLHAR: INTRODUÇÃO........................................................ 17

1.1 DESAFIOS NO PERCURSO ............................................................................................. 26

CAPÍTULO 2 - O OLHAR DA LITERATURA ACADÊMICA: ESTADO DA ARTE .......... 29

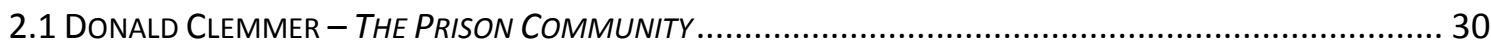

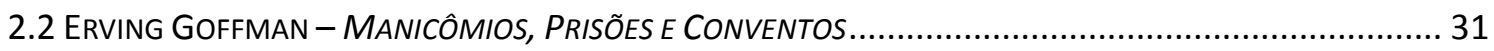

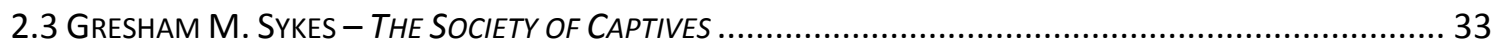

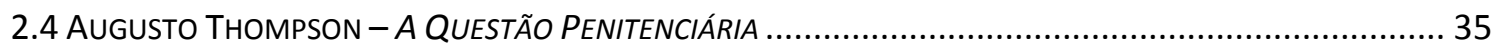

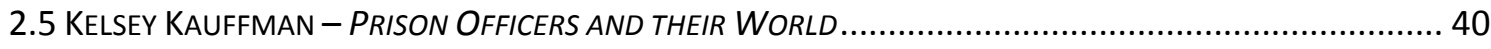

2.6 Antoinette Chauvenet, Françoise Orlic E Georges Benguigui - Le Monde des SURVEILlaNtS DE

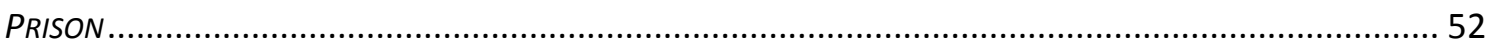

2.7. LUIZ ANTÔNIO BOGO CHIES - A PRISIONALIZAÇÃO do AGENTE PENITENCIÁRIO:

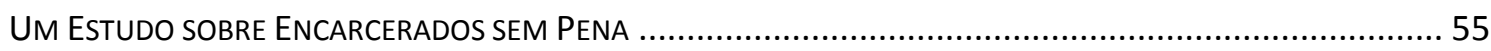

2.8. Pedro Rodolfo BodÊ de Moraes - Punição, EnCARCERAMENTO E ConstruÇão da IDENTIDAdE

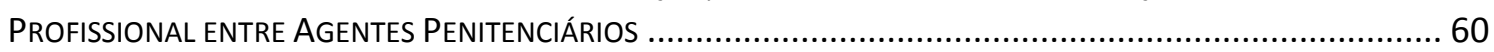

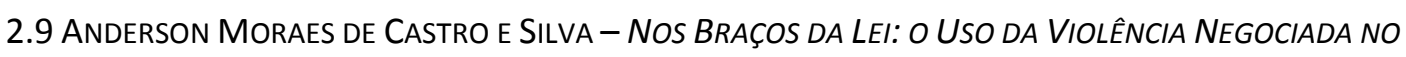

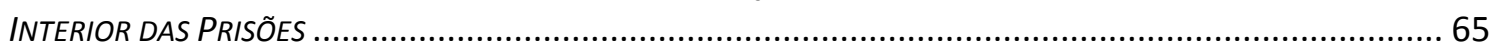

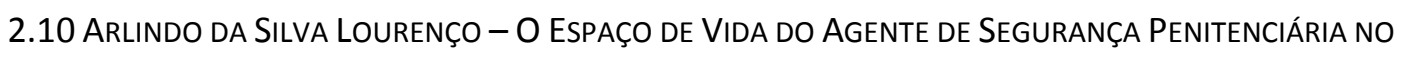

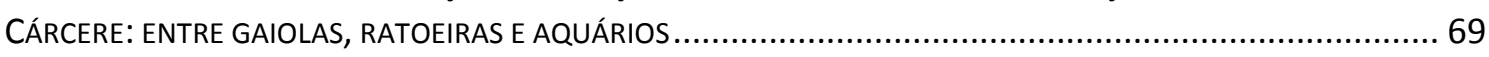

2.11 ADRIANA REZENDE FARIA TAETS - ABRINDO E FECHANDO CELAS: NARRATIVAS, EXPERIÊNCIAS E

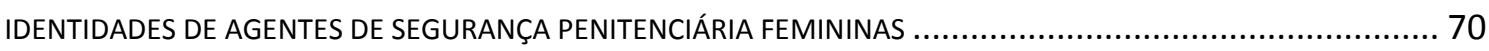

2.12 Raphael SabainI - Uma Cidade entre Presídios: Ser Agente Penitenciário em ItiRapina - SP ... 74

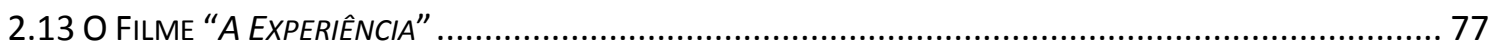

CAPÍTULO 3 - CAPTANDO O OLHAR DO JUDICIÁRIO: METODOLOGIA.................... 79

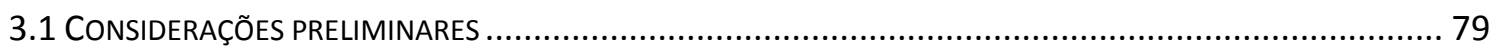

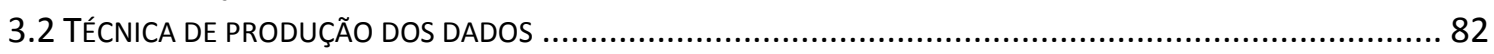

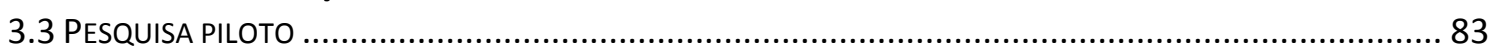

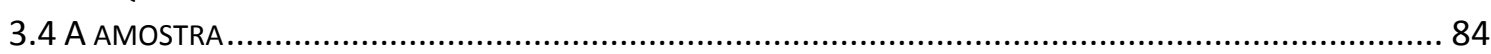

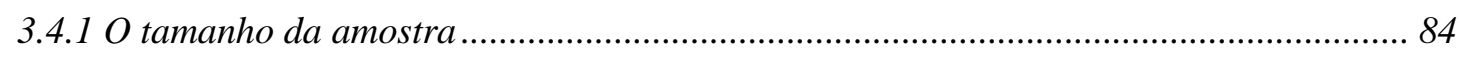

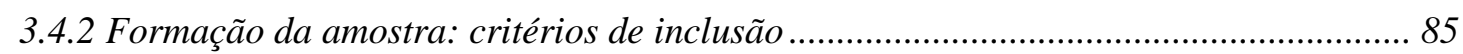

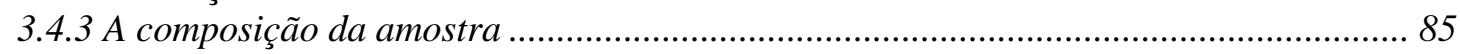

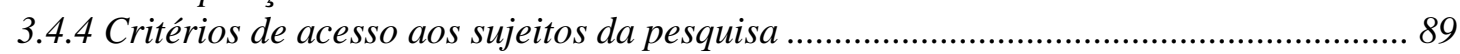

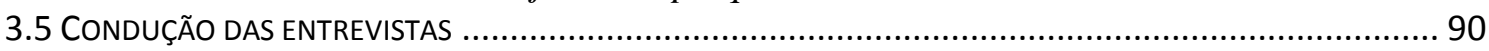

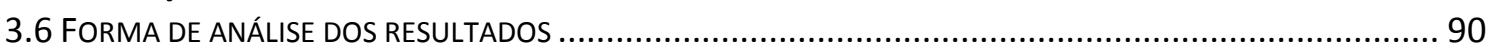

CAPÍTULO 4 - O OLHAR DO JUDICIÁRIO: APRESENTAÇÃO E ANÁLISE DOS

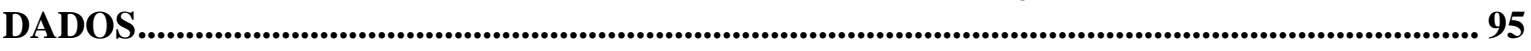

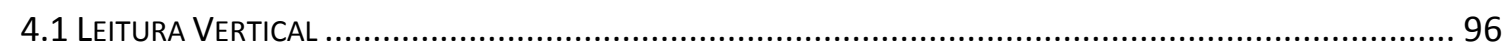

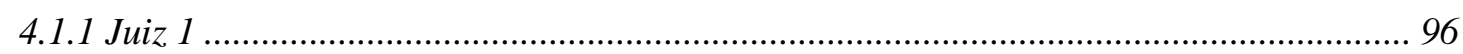

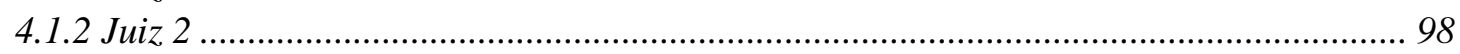

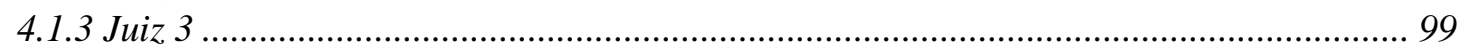

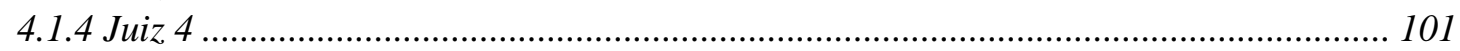

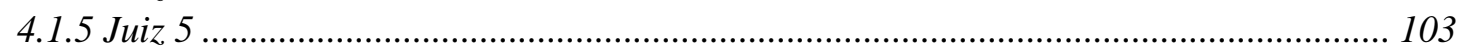

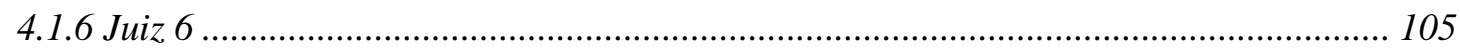

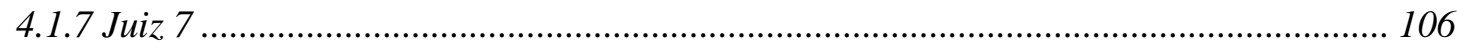

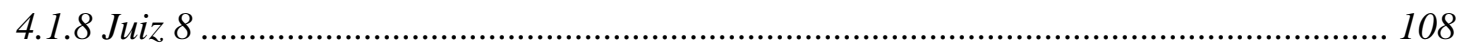




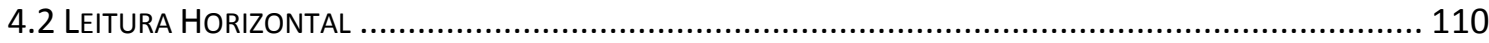

4.2.1 Categoria 1: Preparo, papel e formas de atuação do ASP .......................................... 111

4.2.2 Categoria 2: Relacionamento entre os ASPs e o Poder Judiciário.................................. 114

4.2.3 Categoria 3: Relacionamento entre os ASPs e os presos............................................ 117

4.2.4 Categoria 4: Relacionamento entre os ASPs e a direção da unidade prisional

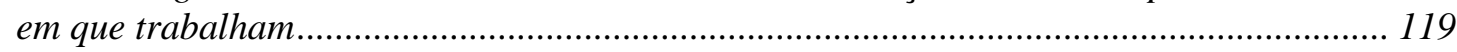

4.2.5 Categoria 5: Probidade dos ASPs...................................................................... 120

4.2.6 Categoria 6: Vulnerabilidade e segurança do ASP no exercício da sua profissão ..... 122

4.2.7 Categoria 7: Valorização, por parte do Poder Judiciário, do depoimento do ASP .... 124

4.2.8 Categoria 8: Condições de trabalho do ASP ......................................................... 125

4.2.9 Categoria 9: Fatores emocionais relacionados ao trabalho do ASP............................. 126

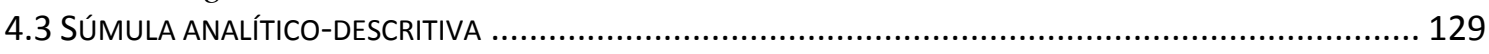

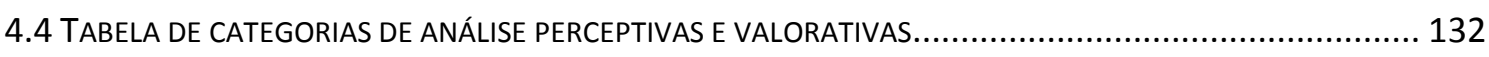

\section{CAPÍTULO 5 - OLHARES CONVERGENTES E DIVERGENTES: DISCUSSÃO E}

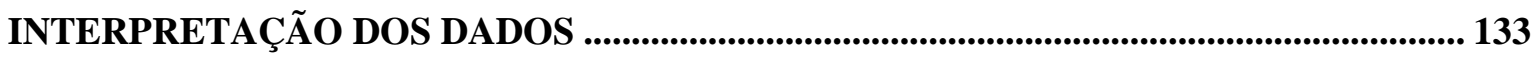

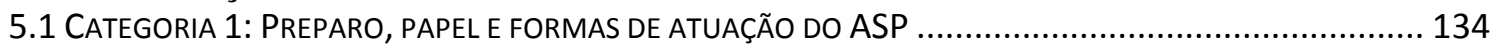

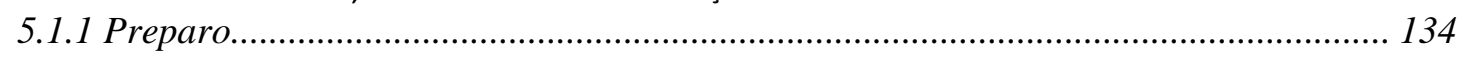

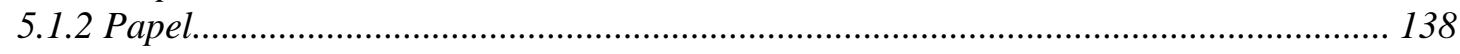

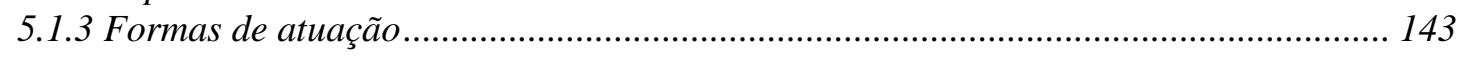

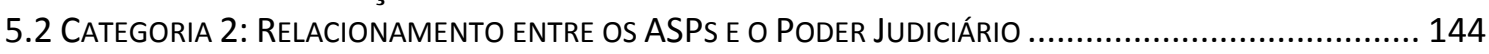

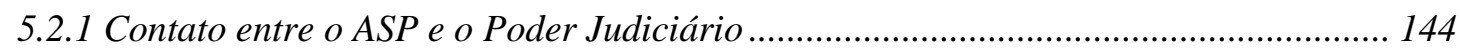

5.2.2 Irregularidades cometidas nos presídios ………......................................................... 145

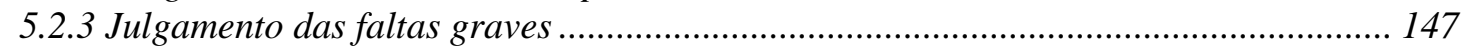

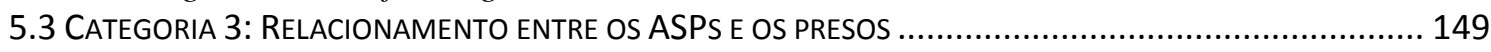

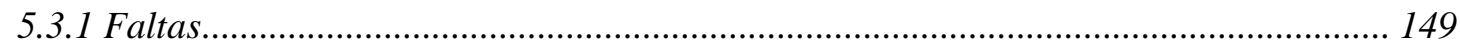

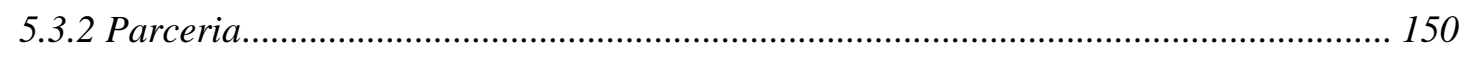

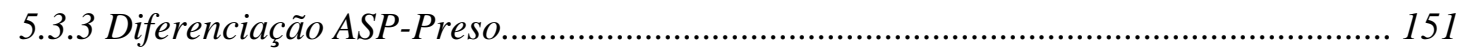

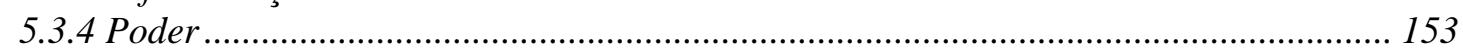

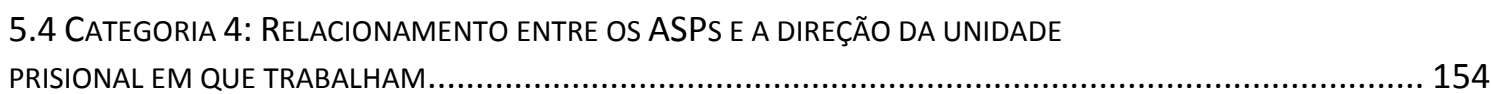

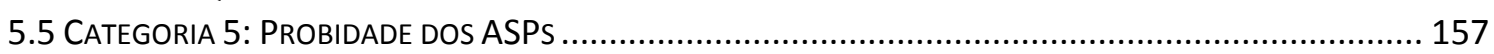

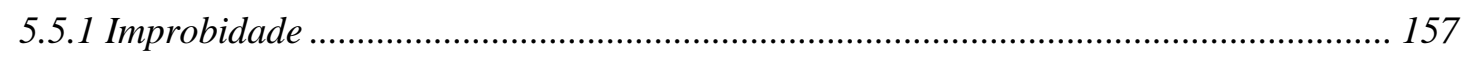

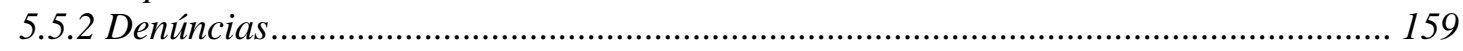

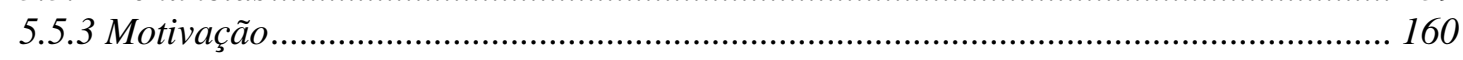

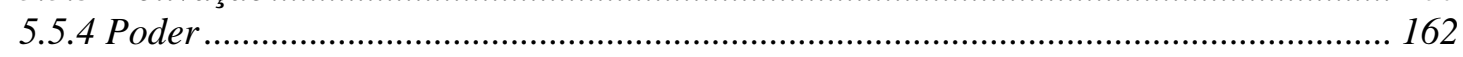

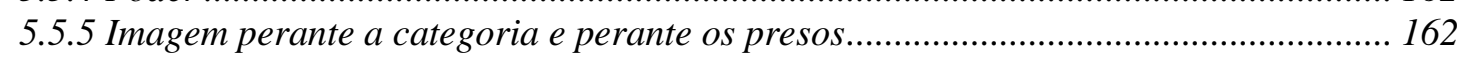

5.6 CATEGORIA 6: VULNERABILIDADE E SEGURANÇA DO ASP NO EXERCÍCIO DA SUA

5.7 CATEGORIA 7: VALORIZAÇÃO, POR PARTE DO PODER JUDICIÁRIO, DO DEPOIMENTO

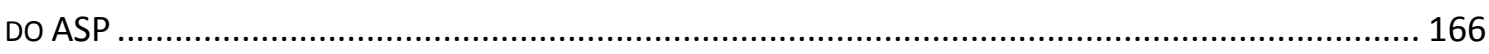

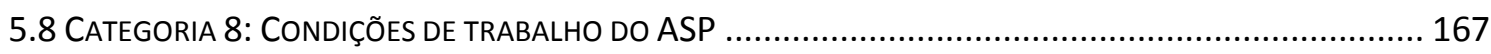

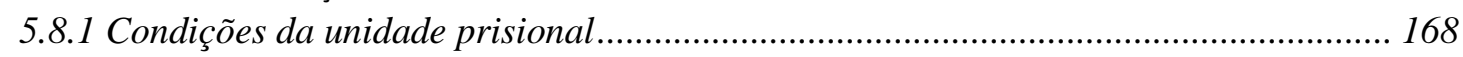

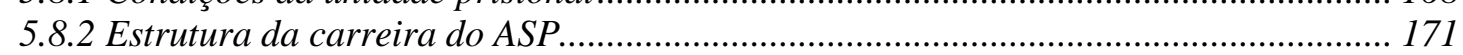

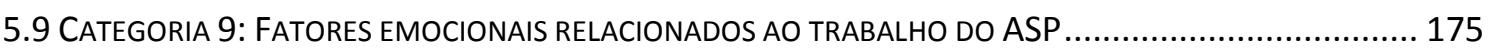

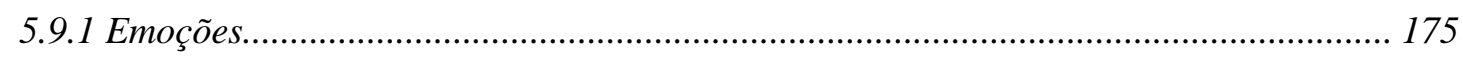

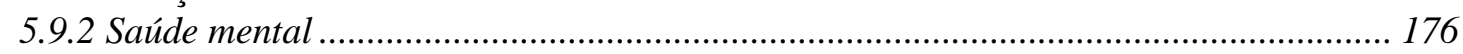

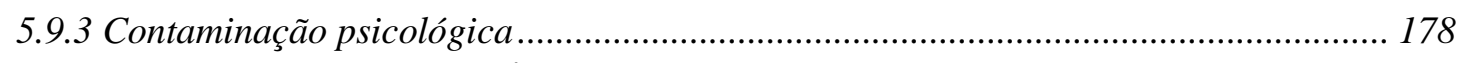

5.10 CATEGORIA 10: IMPACTO DA EXISTÊNCIA DO CRIME ORGANIZADO NA ATUAÇÃO

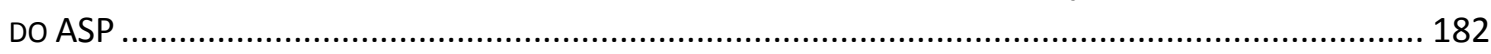

5.10.1 Algumas características sobre as facções criminosas no Estado de São Paulo ......... 182

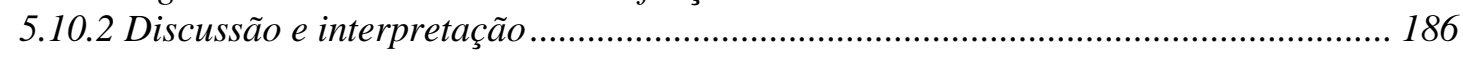




\section{CAPÍTULO 6 - UM OLHAR REFLEXIVO: CONCLUSÕES}

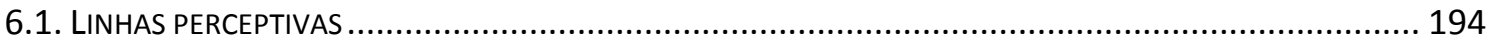

6.1.1 Função do ASP: ressocializadora vs. disciplinar ........................................................ 195

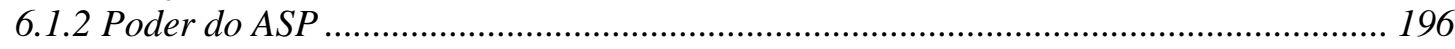

6.1.3 Influência da faç̧ão criminosa no trabalho do ASP ..................................................... 196

6.1.4 Impactos psicossociais do trabalho do ASP ................................................................. 197

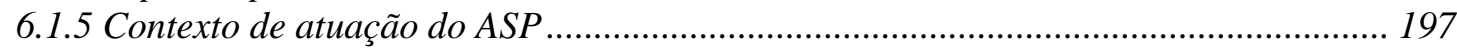

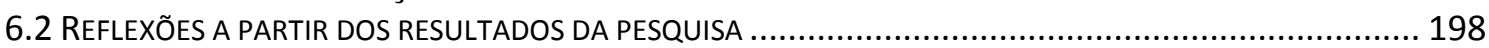

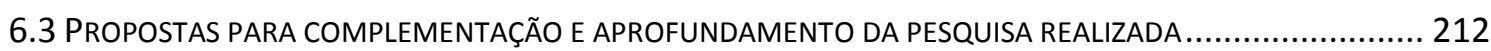

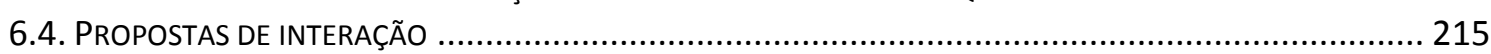

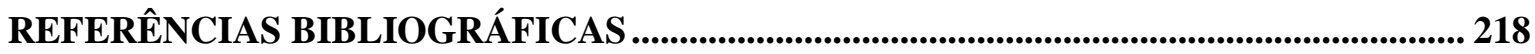

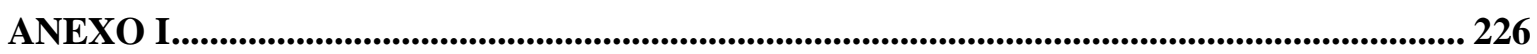

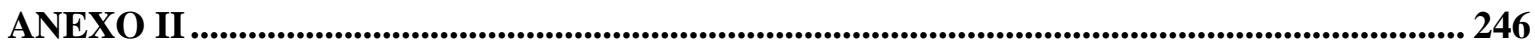




\section{APRESENTAÇÃO}

\section{A pesquisadora}

É importante apresentar ao leitor o local de onde o pesquisador parte para a realização de seu estudo, e é isso que faço aqui, antes que se dê início à leitura do trabalho propriamente dito. Aqui é a única parte em que falarei na primeira pessoa.

O sofrimento humano sempre exerceu sobre mim forte impacto emocional e as lutas contra a opressão sempre me mobilizaram. Como armas para essas batalhas contra a violência, venho desenvolvendo habilidades ligadas à pesquisa, à litigância jurídica e à militância pela defesa dos Direitos Humanos.

Correm em minhas veias histórias de sobreviventes e de bravos guerreiros da justiça, como de um avô fugitivo de um campo de concentração no período da $2^{\mathrm{a}}$ Guerra Mundial e de um bisavô que trocou toda sua fortuna por livros para trazer ao Brasil em sua fuga, ao se sentir ameaçado pela Revolução Russa de 1917. Soma-se a isso a educação construtivista a que tive acesso durante os ensinos fundamental e médio, que começaram a me dar réguas e compassos para enfrentar os combates.

Cursar um ano da Faculdade de História da USP me fez refletir sobre o fio condutor da história e seus tropeços. Percebi que a história contada “oficialmente” esconde as singularidades das trajetórias e do sofrimento dos vencidos.

O ingresso na Faculdade de Direito da USP permitiu que eu começasse a desenvolver habilidades jurídicas, as quais têm grande potencial para a promoção da Justiça, se bem usadas.

Após a formatura, a experiência como pesquisadora no Núcleo de Estudos da Violência da USP me permitiu conhecer pessoas fortes, competentes e generosas que me ensinaram, sobretudo, a enxergar a ferramenta científica como poderoso instrumento impulsionador de transformações. 
Tenho participado do Grupo de Diálogo Universidade Cárcere Comunidade GDUCC $^{1}$ - desde 2010 como coordenadora adjunta, sendo que já havia participado de grupo semelhante em 2008. Esses encontros de diálogo na prisão me permitiram conhecer muitas pessoas que estão presas e também conversar com diversos agentes penitenciários e entrar em contato, através de palavras e olhares, com algumas das mais agudas feridas de nosso momento histórico.

Desde o início de 2011, atuo como advogada no Programa de Justiça ${ }^{2}$ na Organização Não Governamental Conectas Direitos Humanos ${ }^{3}$. Minha atuação, especificamente, está muito voltada para os temas relacionados ao sistema carcerário e de justiça criminal ${ }^{4}$.

Pelo projeto de advocacy frente aos Poderes Legislativo e Executivos federais em temas de justiça criminal - desenvolvido em parceria com outras importantes ONGs - tive oportunidade de me reunir com deputados, senadores e membros do Poder Executivo para tratar tais questões.

Além disso, a possibilidade de trocar informações e experiências com outros ativistas sobre o sistema prisional, inclusive em fóruns internacionais, é enriquecedora e fonte de informação e de renovação da energia para continuar a lutar.

Por ter status consultivo junto às Nações Unidas, a Conectas participa de modo ativo nas discussões e tenta influenciar as decisões tomadas neste âmbito no que diz respeito aos Direitos Humanos, com muita ênfase sobre as questões relativas ao sistema prisional. Já representei a instituição em Consulta Regional com o Relator Especial das Nações Unidas sobre a Tortura, Juan Méndez, no Chile ${ }^{5}$ e em encontro do Grupo

1 O GDUCC iniciou suas atividades em 2006, no âmbito do Departamento de Direito Penal, Medicina Forense e Criminologia da Faculdade de Direito da USP, sob a coordenação do Professor Doutor Alvino Augusto de Sá e do Professor Titular Sergio Salomão Shecaira. O grupo tem por objetivo o alcance da reintegração social e os encontros são pautados pelo diálogo entre os participantes presos e não presos. Vide SÁ, Alvino Augusto de. Criminologia Clínica e Execução Penal: proposta de um modelo de terceira geração. São Paulo: RT, 2011, p. 318-346; SÁ, Alvino Augusto de. GDUCC Grupo de Diálogo Universidade, Cárcere, Comunidade- - experiência que está dando certo. Boletim IBCCRIM, v. 198, p. 11-12, 2009; BRAGA, Ana Gabriela Mendes; BRETAN, Maria Emília. Teoria e prática da reintegração social: o relato de um trabalho crítico no âmbito da execução penal. In: SÁ, Alvino Augusto de; SHECAIRA, Sérgio Salomão (Org.). Criminologia Aplicada aos Problemas da Atualidade. São Paulo: Atlas, 2008, p. 255-275.

${ }^{2}$ Vide <http://www.conectas.org/artigo-1>. Acesso em: 21 dez. 2012.

${ }^{3}$ Vide <www.conectas.org $>$. Acesso em: 21 dez. 2012.

${ }^{4}$ Vide < http://www.conectas.org/artigo-1/sistema-prisional>. Acesso em: 21 dez. 2012.

${ }^{5}$ Vide <http://www.conectas.org/politica-externa/onu-undefinedum-impulso-extremamente-necessario-paraerradicar-a-tortura-na-america-latina-e-no-caribeundefined. ; http://www.conectas.org/politicaexterna/resultados-da-consulta-regional-latino-americana-com-relator-da-onu-para-tortura>. Acesso em: 21 dez. 2012. 
Intergovernamental de Especialistas para a revisão das Regras Mínimas de Tratamento do Preso $^{6}$, em Buenos Aires, o que me permitiu ter uma visão panorâmica da condição prisional no mundo.

É este o locus de onde parto para a construção e desenvolvimento desta pesquisa, que é mais um passo na busca por respostas e, mais do que isso, por novas perguntas sobre o contexto do cárcere, local de sofrimento humano e opressão, em uma perspectiva criminológica.

\section{O trabalho}

O objetivo do presente trabalho consiste na identificação de elementos valorativos e perceptivos que o Poder Judiciário tem em relação ao agente de segurança penitenciária (ASP ou agente).

O primeiro capítulo destina-se a expor a relevância, as justificativas e as limitações da pesquisa, bem como os desafios vividos no percurso.

O segundo capítulo busca resumir o estado da arte no que diz respeito à temática relativa aos agentes penitenciários no contexto bibliográfico consultado. Autores que trabalharam a questão sob diferentes ângulos e perspectivas são apresentados ao leitor. Tais obras serão de especial relevância para a discussão e a interpretação dos dados realizadas mais adiante, no capítulo 5.

O terceiro capítulo discorre sobre a metodologia adotada na pesquisa. Para a consecução dos objetivos do estudo, foram realizadas oito entrevistas semidirigidas com juízes atuantes em Varas de Execução Criminal do Estado de São Paulo. A técnica da coleta dos dados é descrita nesse capítulo, bem como a pesquisa piloto realizada, a apresentação da amostra e sua composição, a forma de abordagem dos entrevistados, o contexto em que se realizaram as entrevistas e o caminho adotado para analisar os resultados.

\footnotetext{
${ }^{6}$ Vide <http://www.conectas.org/politica-externa/conectas-participa-de-debate-sobre-tratamento-de-presosna-onu-em-viena>; <http://www.conectas.org/artigo-1/conectas-participa-de-debate-sobre-tratamento-depresos-na-onu-em-viena>. Acesso em: $21 \mathrm{dez} .2012$.
} 
O capítulo 4 dedica-se a apresentar e analisar os dados coletados nas entrevistas, de acordo com a divisão em categorias de análise realizada - conforme explicado no capítulo sobre metodologia.

Foram criadas dez categorias de análise que são estruturadoras de todo o trabalho. São elas:

1. Preparo, papel e formas de atuação do ASP;

2. Relacionamento entre os ASPs e o Poder Judiciário;

3. Relacionamento entre ASP e preso;

4. Relacionamento entre ASP e a direção da unidade prisional em que trabalham;

5. Probidade dos ASPs;

6. Vulnerabilidade e segurança do ASP no exercício da sua profissão;

7. Valorização, por parte do Poder Judiciário, do depoimento do ASP;

8. Condições de trabalho do ASP;

9. Fatores emocionais relacionados ao trabalho do ASP;

10. Impacto do crime organizado na atuação do ASP.

Ao final do capítulo são elaboradas 18 súmulas analítico-descritivas derivadas da apresentação e da análise dos dados.

O capítulo 5 discute e interpreta os dados, segundo a divisão em categorias de análise utilizada no capítulo anterior. Busca-se discernir as diferenças e semelhanças entre, por um lado, a percepção do Judiciário exposta nas entrevistas realizadas e, por outro, os achados dos autores focalizados no capítulo 2. São, ainda, levantadas hipóteses sobre as implicações que a percepção e os aspectos valorativos do Judiciário sobre os agentes penitenciários poderiam produzir.

No capítulo 6, destinado às conclusões, são colocadas em relevo as principais contribuições da pesquisa, em especial, a identificação dos temas de destaque que premeiam a visão do Judiciário sobre os ASPs e as tendências e as ênfases prevalecentes em cada um deles. Os temas são agrupados em cinco linhas perceptivas:

1. Função do ASP: ressocializadora vs. disciplinar;

2. Poder do ASP;

3. Influência da facção criminosa no trabalho do ASP;

4. Impactos psicossociais do trabalho do ASP; 
5. Contexto de atuação do ASP.

Em seguida, no mesmo capítulo, é realizado um conjunto de reflexões críticas com base nos resultados da pesquisa, na análise da literatura estudada e em diálogo com as vivências profissionais da pesquisadora.

Por fim, foram sugeridos temas para novas pesquisas a partir dos achados desta e apresentadas propostas de interação entre os principais especialistas e atores no processo de execução penal. 


\section{Capítulo 1}

EM BUSCA DO OLHAR:

INTRODUÇÃO

O tema da presente dissertação se insere na problematização da profissão do agente de segurança penitenciária (ASP ou agente ou agente penitenciário), do papel que desempenha e do valor atribuído a esta profissão.

A relação que se constitui entre os agentes de segurança penitenciária e o cárcere é complexa, fruto de múltiplos elementos, dentre eles os fatores institucionais características da Instituição em que trabalham, seus objetivos, normas, recursos humanos, relacionamento com o Poder Judiciário, aspectos ambientais, econômicos etc. - que interagem com os fatores individuais e subjetivos de cada agente - familiar, psicológico, social, financeiro etc. - e que são influenciados pelas características da população carcerária específica.

A pesquisa que ora se apresenta tem por objetivo a identificação de elementos valorativos e perceptivos que o Poder Judiciário tem do ASP.

Tais questões são de extrema valia para a compreensão mais aprofundada do papel desempenhado pelo agente no contexto carcerário, já que acaba por impactar diretamente o desempenho de suas funções profissionais. Nesse sentido, dentre outros, a visão que o Poder Judiciário tem dos ASP se reflete na dinâmica carcerária.

A interferência se dá em algumas esferas distintas: a percepção que o Poder Judiciário tem do ASP produz efeitos na autoimagem destes - a imagem que os grupos formam do ASP, por sua vez, produz reflexos diretos na autoimagem destes, o que acarreta efeitos no seu desempenho profissional e também nas demais esferas de sua vida; o grau de valorização conferido aos ASPs pelo Judiciário influencia, mesmo que indiretamente, as decisões judiciais; os ASPs passam a incorporar no seu exercício profissional a valorização do Judiciário em relação a eles etc.

Para se atingir o objetivo proposto foi necessário compreender e captar o fenômeno estudado a partir da perspectiva das pessoas envolvidas. O que implicou, portanto, uma necessidade de se desenhar uma metodologia de pesquisa de campo em que os elementos 
pudessem ser colhidos na própria fala dos representantes do Poder Judiciário. A pesquisa empírica, neste caso, mostrou-se imperiosa para a consecução do objetivo da investigação. Para se alcançar saber e, posteriormente, discutir e interpretar os elementos valorativos e perceptivos do Poder Judiciário sobre os agentes penitenciários foi fundamental ouvir o que os juízes tinham a dizer sobre o tema.

O estudo que agora se apresenta almeja ampliar a compreensão sobre o universo do agente penitenciário e, como consequência, do sistema prisional, e, assim, possibilitar uma maior reflexão sobre a prática carcerária, a partir de uma perspectiva criminológica.

Pesquisas de campo não são comuns em trabalhos de pós-graduação nas faculdades de Direito do Brasil, porém, constituem uma ferramenta essencial para a descoberta e compreensão das consequências da aplicação do Direito, tal qual é realizada contemporaneamente, no mundo real, no mundo do ser e não apenas em teoria no mundo do dever $\operatorname{ser}^{7}$.

O Direito é uma ciência humana que interfere na realidade e, por reação, a realidade responde e promove alterações nos mundos legislativo, jurisprudencial e doutrinário. Sendo assim, é inegável a importância dos trabalhos que envolvem as pesquisas de campo. Já na Criminologia, ciência em que este trabalho está inserido, as pesquisas de campo são comuns e constituem ferramenta essencial para o seu desenvolvimento.

A Criminologia é uma ciência que permite o trânsito entre as demais ciências humanas e se utiliza de ferramentas típicas destas na análise e na coleta de dados que digam respeito aos objetos da própria Criminologia.

\footnotetext{
${ }^{7}$ Atualmente há um movimento para o aumento das pesquisas empíricas em Direito. Um exemplo disso é a Rede de Estudos Empíricos em Direito (REED). “A REED é uma iniciativa de professores e pesquisadores envolvidos com pesquisa empírica em Direito e interessados em melhor compreender e disseminar metodologias e ferramentas adequadas. A REED visa a articulação horizontal e acêntrica dos pesquisadores no Brasil e no exterior, a divulgação de trabalhos e informações relacionadas e a difusão e capacitação em métodos de pesquisa empírica em Direito.” Disponível em: <http://reedpesquisa.org/>. Acesso em: 10 nov. 2012.

A Rede de Estudos Empíricos em Direito (REED) foi formada após o I Encontro de Pesquisa Empírica em Direito, ocorrido em setembro de 2011, na Faculdade de Direito de Ribeirão Preto da USP. A Rede é composta por pesquisadores de diversas instituições e áreas do conhecimento que "compartilham a visão de que é preciso aprimorar o empirismo nas Ciências Jurídicas, modificando o foco de análise dos 'direitos nos livros’ para o 'direito em ação’ (a velha distinção entre law in books e law in action promovida pela Sociologia Jurídica estadunidense)”. Disponível em: <http://www.direito.ufg.br/pages/37266>. Acesso em: 10 nov. 2012.
} 
Esse trânsito por disciplinas e pelas fronteiras disciplinares não significa negar suas delimitações próprias, pelo contrário, a existência dessas disciplinas depende dos objetos de estudos, de sua delimitação e do referencial analítico e teórico utilizado. Significa, isso sim, assumir que os temas e os métodos podem ser compartilhados e (re) significados. ${ }^{8}$

A Criminologia tem como objetos de estudo o delito, o delinquente, a vítima e o controle social do delito; "e, para tanto, lança mão de um objeto empírico e interdisciplinar” ${ }^{9}$. De acordo com a definição dada por SUTHERLAND e citada por ANITUA, a Criminologia é o "corpo de conhecimentos que observa o delito como um fenômeno social. Inclui, dentro de seus objetos, os processos de elaborar leis, de descumprir leis e de reagir contra quem descumpriu as leis” ${ }^{10}$.

A Criminologia se debruça sobre a realidade para compreendê-la e explicá-la, utilizando-se de recursos interdisciplinares, ou seja, aproveitando-se de outras ciências como a Sociologia, a Antropologia, a Psicologia, a Medicina e o Direito. "Diferentemente do Direito Penal, a Criminologia pretende conhecer a realidade para explicá-la, enquanto aquela Ciência valora, ordena e orienta a realidade, com o apoio de uma série de critérios axiológicos”11.

Segundo ANITUA,

\begin{abstract}
essa trans, pluri ou interdisciplinaridade é levada a cabo quando um complexo integrado de disciplinas acadêmicas discorre sobre o objeto "questão criminal", e cria um novo discurso que seleciona e organiza resultados provenientes de outras disciplinas acadêmicas, mas, ao mesmo tempo, mantém a autonomia estratégica e a hegemonia do discurso específico em relação àquelas. ${ }^{12}$
\end{abstract}

A pesquisa está inserida na problematização do controle social do desvio - não apenas de práticas de crimes, mas também de infrações a outras determinações legais, como as faltas graves - ao estudar a visão que o Poder Judiciário tem dos ASPs, ou seja, a visão que um órgão responsável pelo controle social formal do desvio nutre pelos funcionários responsáveis por executar a punição formal ao desvio.

\footnotetext{
${ }^{8}$ Angotti, Bruna. Entre as leis da ciência, do Estado e de Deus: o surgimento dos presídios femininos no Brasil.,São Paulo: IBCCrim, 2012. (Monografias IBCCRIM n. 62). p. 37.

${ }^{9}$ SHECAIRA, Sérgio Salomão. Criminologia. São Paulo: RT, 2004. p. 38.

10 AnituA, Gabriel Ignacio. Histórias dos pensamentos criminológicos. Rio de Janeiro: Revan, 2008. (Coleção Pensamento Criminológico v. 15). p. 20.

${ }^{11}$ SHECAIRA, Sérgio Salomão. Op. cit., p. 38.

12 AnITUA, Gabriel Ignacio. Op. cit., p. 19.
} 
A intenção é se debruçar sobre a imagem que o Poder Judiciário, enquanto instância formal de controle (que possui grande influência no sistema penitenciário e é um dos protagonistas do sistema de Justiça) tem em relação ao agente penitenciário.

O Poder Judiciário tem a função de sanar os conflitos sociais que não podem, não puderam ou não foram resolvidos em outros campos da vida social, como o da negociação informal e/ou da esfera administrativa. As partes recorrem a um terceiro, supostamente neutro, e investido por lei de poder para solucionar o impasse que as perturba.

Quando se fala da atuação do Poder Judiciário na esfera criminal, estamos diante de situações e de conflitos que a lei considera de extrema gravidade e, por isso, transfere para os magistrados, terceiros neutros devidamente habilitados, o poder-dever de julgar as condutas tipificadas criminalmente - podendo resultar até na repressão máxima prevista no ordenamento jurídico brasileiro, a privação da liberdade.

Os casos de desrespeito às normas administrativas, que não configurem crimes e que ocorrem dentro dos presídios, são apreciados pelos juízes das Varas de Execução Criminal. São tais juízes os primeiros a julgarem o conflito judicializado ocorrido no interior das prisões.

Esses juízes lidam cotidianamente com situações que tiveram como cenário as penitenciárias, centros de detenção provisória, locais de cumprimento de pena em regime semiaberto, colônias penais agrícolas etc.; ou seja, estabelecimentos penais ${ }^{13}$ destinados ao cumprimento de pena por adultos.

Assim, o objetivo do trabalho é identificar, por meio de entrevistas com juízes, elementos perceptuais e valorativos acerca do agente penitenciário.

Neste sentido, por opção metodológica ${ }^{14}$, a pesquisa versará sobre a valorização e percepção que os juízes que atuam nas Varas de Execução Criminal do Estado de São Paulo têm sobre os ASPs.

\footnotetext{
${ }^{13}$ Aqui, faz-se uma importante ressalva terminológica. Os termos "penitenciária”, “cadeia”, "prisão”, "cárcere”, "estabelecimento prisional”, "estabelecimento penitenciário", "unidade prisional” e outros semelhantes serão utilizados na presente dissertação como sinônimos, já que no Estado de São Paulo as diferenças estabelecidas em lei entre estes estabelecimentos não se verificam na prática. Portanto, os termos serão utilizados com o fim de se referir a locais de privação de liberdade de adultos.

${ }^{14}$ Vide infra capítulo 3.
} 
Ao mesmo tempo em que o Poder Judiciário está distante da vida prisional, ele desempenha papel fundamental nela. Cabe ao Poder Judiciário decidir quem ficará preso e, portanto, quem passará a compor a dinâmica intramuros.

O Poder Judiciário é o responsável por solucionar demandas e conflitos presentes nas cadeias que não foram resolvidos por outros meios. O Poder Judiciário não está sujeito à contaminação do cotidiano do cárcere, por não vivenciar as experiências corriqueiras e habituais, mas como suas decisões têm força máxima de imposição e devem ser cumpridas, esse Poder exerce influência direta na dinâmica carcerária.

Além de exercer influência direta no mudo prisional por meio de decisões sobre progressão de regime, transferência de presos para o Regime Disciplinar Diferenciado, julgamento sobre o cometimento de faltas graves, e determinando que pessoas devem ou não ser mantidas presas - na fase de prisão provisória e/ou por via das sentenças criminais condenatórias definitivas, o Poder Judiciário é responsável, também, pelo controle externo das prisões. Nesse sentido, para exercer seu poder de modo mais consistente com a realidade e, assim, influenciar de modo mais incisivo e intencional a dinâmica carcerária, é importante que o Judiciário conheça a realidade do universo prisional.

O Poder Judiciário se aproxima do sistema carcerário por meio das visitas de inspeção realizadas pelo juiz da Vara de Execução Criminal - que deve realizá-la mensalmente - e pelos relatos de terceiros, nos casos de processos de conhecimento que versem sobre um crime ocorrido dentro das prisões ou nos casos de procedimentos para apuração de falta grave.

Deste modo, as informações que atingem o Poder Judiciário já foram anteriormente filtradas. Nos processos constam apenas as versões dos envolvidos, que deixam transparecer apenas o que consideram importante, interessante ou adequado fazer naquele momento específico. Nas visitas de inspeção existe um grau de informações que são aferidas pela percepção do próprio juiz, mas a maioria das informações advém dos relatos dos presos, do diretor da unidade prisional e, eventualmente, dos agentes penitenciários.

Faz-se essencial que a Academia aprofunde o seu conhecimento sobre os agentes penitenciários, já que constituem um grupo fundamental para o estabelecimento das relações no interior das penitenciárias. Contudo, estudos acerca dos agentes penitenciários parecem ter sido deixados em segundo plano. Tal elemento não é por acaso, ele é sintomático de uma situação de subvalorização da carreira de agente penitenciário e de seu 
papel ativo na construção das dinâmicas penitenciárias. A valorização desta classe de profissionais como essencial para a formação do cotidiano prisional também não é realizada pelos órgãos públicos que atuam na temática. Para tal constatação basta verificar o plano de carreira ${ }^{15}{ }_{-}^{16}$.

Assim, não se trata de um estudo sobre o cotidiano prisional, ou seja, não se tem a intenção de estudar os conflitos e desentendimentos que acontecem nas prisões, mas como os juízes das Execuções Criminais do Estado de São Paulo percebem e valorizam o ASP.

Os dados coletados foram categorizados de forma a permitir uma análise criminológica dos elementos encontrados na pesquisa.

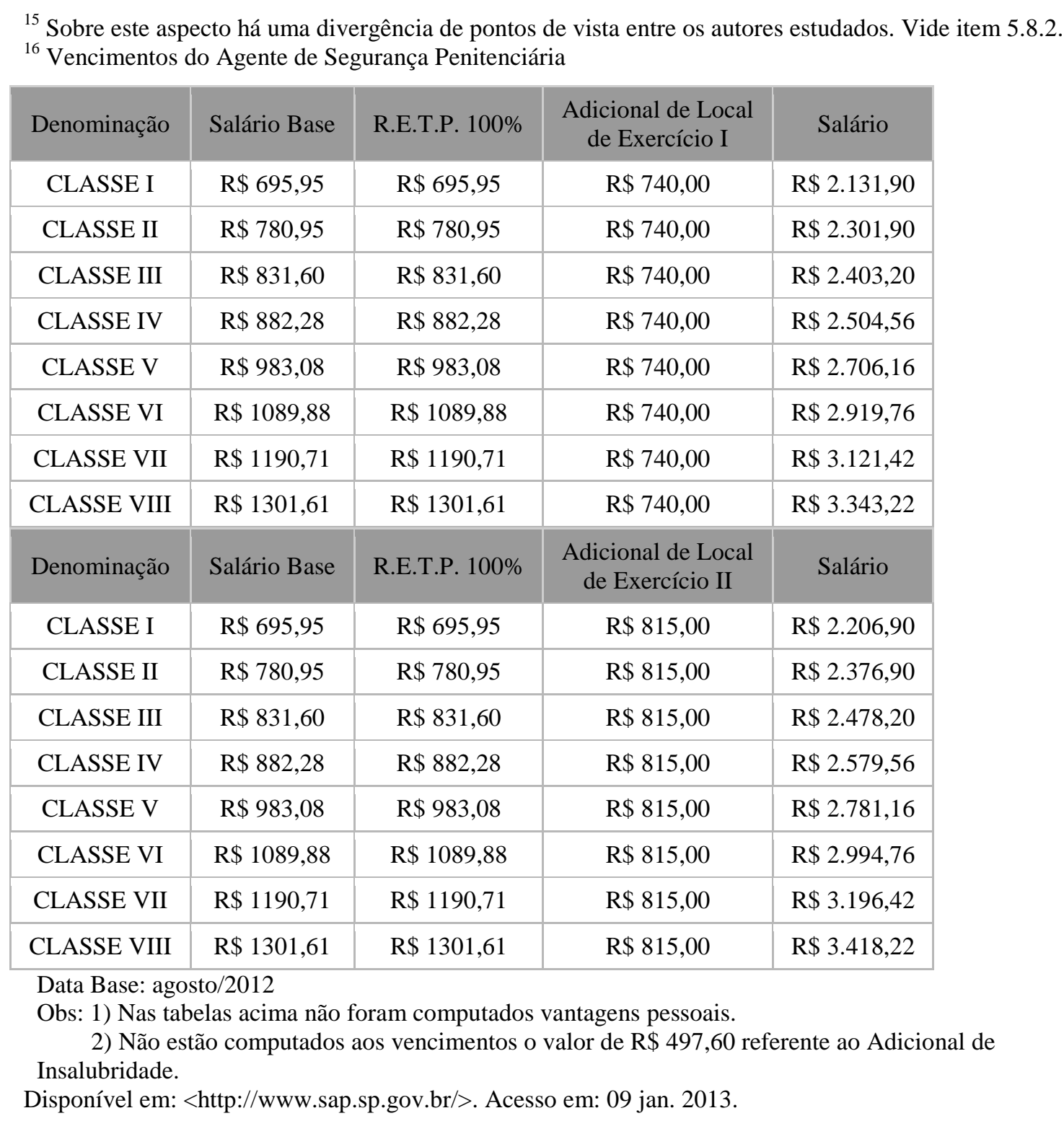


Optou-se por entrevistar apenas juízes atuantes nas Varas de Execução Penal, pois a Lei de Execução Penal as considera como Órgão da Execução Penal ${ }^{17}$. Deste modo, como se trata de Órgão que está próximo dos conflitos, os capta quando ainda estão permeados das emoções dos acontecimentos.

Além disso, estes juízes têm a obrigação legal de visitar mensalmente as unidades prisionais $^{18}$, o que faz com que tenham um conhecimento, ao menos em tese, mais aprofundado do que é o universo existente dentro dos muros.

No contexto da análise, é importante destacar que a Lei de Execução Penal determina, em seu artigo 48, parágrafo único, que "nas faltas graves, a autoridade representará ao juiz de execução (...)” para os fins de regressão de regime e revogação de benefício quando o preso tiver cometido crime doloso ou falta grave, e para perda de tempo remido quando o preso tiver cometido falta grave.

Ou seja, nos casos acima mencionados o conflito deverá obrigatoriamente, de acordo com a legislação, ser levado para a apreciação do juiz da execução.

A lei determina que sejam apreciados pelo juiz, o que não significa dizer que isso é o que realmente acontece em todos os casos; aliás, segundo diversos autores, como CASTRO E SILVA $^{19}$ e KAUFFMAN ${ }^{20}$, ocorre o contrário: há uma negociação anterior entre as personagens que convivem nas prisões, que atua como um primeiro filtro, fazendo com que diversos casos não sejam levados nem ao conhecimento da Administração Penitenciária e, menos ainda, ao conhecimento do Poder Judiciário, por mais que assim determine a lei.

A pouca produção acadêmica acerca dos agentes penitenciários é na realidade uma lacuna que não deveria existir, já que o papel exercido por esses profissionais é de extrema importância, e seu estudo pode contribuir para uma análise mais aprofundada do sistema prisional. Poucos trabalhos acadêmicos são destinados a tal problemática.

\footnotetext{
${ }^{17}$ Lei 7.210/84 - Lei de Execução Penal: “Art. 61. São órgãos da execução penal: (...) II - o Juízo da Execução. (...)”.

${ }^{18}$ Lei 7.210/84 - Lei de Execução Penal: “Art. 66. Compete ao Juiz da execução: (...) VII - inspecionar, mensalmente, os estabelecimentos penais, tomando providências para o adequado funcionamento e promovendo, quando for o caso, a apuração de responsabilidade. (...)”.

${ }^{19}$ CAstro e Silva, Anderson Moraes de. Nos braços da lei: o uso da violência negociada no interior das prisões. Rio de Janeiro: e+a, 2008.

${ }^{20}$ KauffMAn, Kelsey. Prison officers and their world. Massachusetts: Harvard University Press, 1988.
} 
PedRo BodÊ De Moraes dedicou seu doutorado a essa temática e, ao descrever suas dificuldades, relatou que "ao procurarmos material sobre os agentes penitenciários (...) observamos que era muito pequena a produção de pesquisas, trabalhos e reflexões sobre o sistema penitenciário, no caso dos agentes penitenciários, ela é quase inexistente" ${ }^{21}$.

A mesma dificuldade é relatada por ElAine CRAWLEY, na Inglaterra, ao escrever sua tese de doutorado sobre a mesma temática:

\begin{abstract}
Como resultado da grande quantidade de trabalhos focados na vida dos presos, nós sabemos bastante sobre o impacto da prisão neles, sobre as maneiras pelas quais cada preso tenta se ajustar para viver na prisão e as formas pelas quais eles lidam com (e às vezes são incapazes de lidar com) a rotina, demandas e pressões da vida na prisão. Em contraste, sabe-se muito pouco sobre o impacto da prisão nos funcionários uniformizados. ${ }^{22}$
\end{abstract}

Conclui-se, portanto, que, embora o tema seja importante, a produção científica voltada para a questão está longe de o ter esgotado.

Além disso, a maioria dos trabalhos que coloca os agentes penitenciários como grupo central em suas análises o faz a partir de entrevistas com os próprios ASPs ou observações participantes. Pretende-se aqui fazer uma análise criminológica que diga respeito ao ASP sob outra perspectiva.

As entrevistas com os agentes permitem uma interessante e rica análise a partir do olhar do próprio ASP. As observações participantes permitem que o pesquisador acompanhe o cotidiano do ASP e o descreva em detalhes, a partir do seu próprio olhar sem desconsiderar a interferência que o próprio pesquisador gera no ambiente e nas relações que ali se desenvolvem.

A presente dissertação se estrutura a partir da realização de entrevistas com juízes das Varas de Execução Criminal. Deste modo, a análise será feita a partir do olhar externo

\footnotetext{
${ }^{21}$ MorAES, Pedro Rodolfo Bodê de. Punição, encarceramento e construção de identidade profissional entre agentes penitenciários. São Paulo: IBCCRIM, 2005. (Monografias IBCCRIM n. 33). ${ }^{\text {p. } 74 .}$

${ }^{22}$ Tradução livre da autora. Do original: "As a result of the large body of work focusing on the lives of prisoners (...) we now know a good deal about the impact of prison on its prisoners, about the ways in which prisoner attempt to adjust to living in prison and the ways in which they cope with (and sometimes are unable to cope with) the routines, demands and pressures of prison life. In contrast, very little is generally known about the impact of the prison on uniformed staff”. CRAWLEY, Elaine. Doing prison work: the public and private lives of prison officers. Portland: Willan Publishing, 2006. p. xi-xii.
} 
de outras personagens fundamentais para a constituição e manutenção da dinâmica carcerária e que não são abarcados nas demais pesquisas já realizadas sobre os ASPs.

Foi utilizado, como fonte de dados, o olhar externo à rotina do cárcere, a fim de recolher materiais importantes que possam se somar aos demais estudos pautados em outras fontes, para que todas essas pesquisas, compondo-se e somando-se, facilitem a compreensão mais abrangente das conflitivas relações que permeiam o mundo dos agentes penitenciários e, por consequência, que permeiam a vida no cárcere.

A relevância da pesquisa proposta se fundamenta, ainda, na situação especial do Estado de São Paulo, se comparada aos demais Estados da Federação, no que se refere à execução penal.

Isso se deve, em primeiro lugar, ao fato de que aproximadamente $35 \%$ da população carcerária do Brasil está concentrada no Estado de São Paulo, segundo dados de dezembro de 2011. De acordo com os dados divulgados pelo Sistema Nacional de Informação Penitenciária - InfoPen - do Departamento Penitenciário Nacional - DEPEN o total da população carcerária naquele período, em todo Brasil, correspondia a 549.577 presos, enquanto só no Estado de São Paulo esse número chegava a $190.818^{23}{ }^{24}$.

Sendo assim, a realização desta pesquisa em um Estado que concentra sozinho em torno de 35\% da população carcerária e tinha, no mesmo período, 462,56 presos/100 mil habitantes ${ }^{25}$, ao passo que o Brasil tinha uma média de 288,14 presos/100 mil habitantes, é de especial interesse ${ }^{26}$.

23 MinistÉRIO DA JustiçA. Departamento Penitenciário Nacional. Sistema integrado de informações penitenciárias - InfoPen. Todas UF’s. Referência 06/2012. Disponível em: <http://portal.mj.gov.br/main.asp?View=\%7BD574E9CE-3C7D-437A-A5B6-

22166AD2E896\%7D\&Team=\&params=itemID=\%7BC37B2AE9-4C68-4006-8B16-

24D28407509C\%7D;\&UIPartUID=\%7B2868BA3C-1C72-4347-BE11-A26F70F4CB26\%7D>. Acesso em: 23 dez. 2012.

24 MinistÉRIO DA JUSTIÇA. Departamento Penitenciário Nacional. Sistema integrado de informações penitenciárias - InfoPen. São Paulo/SP. Referência 06/2012. Disponível em: $<$ http://portal.mj.gov.br/main.asp?View=\%7BD574E9CE-3C7D-437A-A5B6-

22166AD2E896\%7D\&Team=\&params=itemID=\%7BC37B2AE9-4C68-4006-8B16-

24D28407509C\%7D;\&UIPartUID=\%7B2868BA3C-1C72-4347-BE11-A26F70F4CB26\%7D>. Acesso em: 23 dez. 2012.

De acordo com a Secretaria de Administração Penitenciária, no mês de outubro de 2012, o Estado de São Paulo tinha 182.581 presos. Disponível em: <www.sap.sp.gov.br>. Acesso em: 21 dez. 2012.

${ }^{25}$ Ibidem.

26 MinistÉRIO DA JUSTIÇA. Departamento Penitenciário Nacional. Sistema integrado de informações penitenciárias- InfoPen. Todas UF’s. Referência 06/2012. Disponível em: $<$ http://portal.mj.gov.br/main.asp?View=\%7BD574E9CE-3C7D-437A-A5B6-

22166AD2E896\%7D\&Team=\&params=itemID=\%7BC37B2AE9-4C68-4006-8B16- 
A relevância da pesquisa reside, enfim, na integração de todos os fatores abordados acima e na importante constatação de que para podermos pensar e repensar o modelo repressivo brasileiro é fundamental conhecer e compreender o grupo profissional dos ASP, que exerce influência direta sobre o sistema penitenciário, além de ser influenciado por esse sistema também.

\subsection{Desafios no Percurso}

O percurso até a formulação da metodologia adotada na presente pesquisa foi tortuoso. De início, o projeto apresentado para ingresso no programa de pós-graduação consistia na realização de entrevistas com os agentes penitenciários com o objetivo de captar a percepção que estes profissionais têm de sua própria atuação profissional.

Porém, para a aplicação da metodologia desenhada, se fazia necessária a autorização de algum Comitê de Ética em pesquisa, por se tratar de pesquisa com seres humanos. À época, a Secretaria de Administração Penitenciária estava no processo de dar início à operacionalização do seu Comitê de Ética em Pesquisa - CEPSAP ${ }^{27}$. O tempo que iria levar para sua instalação e início de análise dos projetos já apresentados constituiu-se em uma barreira real à realização da pesquisa no prazo imposto pelo programa de pósgraduação a que está vinculada.

Tentou-se, então, submeter o projeto ao Comitê de Ética em Pesquisa com Seres Humanos do Instituto de Psicologia da Universidade de São Paulo - CEPH-IPUSP. O projeto foi protocolado, porém, justamente naquele período, o Comitê estava em processo de renovação do cadastro frente à Comissão Nacional de Ética em Pesquisa (CONEP). Mais uma vez, o prazo que demoraria para retomar o seu regular funcionamento impossibilitaria a realização da pesquisa no prazo estipulado para a conclusão do programa de mestrado.

24D28407509C\%7D;\&UIPartUID=\%7B2868BA3C-1C72-4347-BE11-A26F70F4CB26\%7D>. Acesso em: 23 dez. 2012.

${ }^{27}$ Resolução SAP 83/2010: “Todas as pesquisas a serem realizadas no âmbito do sistema prisional paulista, que envolvam seres humanos, deverão ser analisadas pelos membros do Comitê de Ética. A iniciativa visa garantir que as pesquisas científicas realizadas junto às pessoas que cumprem penas ou àquelas que trabalhem nesses locais sejam desenvolvidas sob a ótica do indivíduo e da coletividade e incorporem os quatro referenciais básicos da bioética, quais sejam: autonomia, não maleficência, beneficência e justiça”. Trecho extraído do sítio eletrônico da Secretaria de Administração Penitenciária do Estado de São Paulo. Disponível em: <http://www.sap.sp.gov.br/>. Acesso em: 21 dez. 2012. 
Todo o processo acima brevemente relatado foi permeado por tentativas de alterar o projeto para obter autorização em tempo hábil para a realização da pesquisa ou para não mais necessitar da autorização. Neste interim, foi proposto à Escola de Administração Penitenciária - EAP - um estudo sobre os currículos e cursos ministrados para os agentes penitenciários recém-ingressados na carreira e também nos cursos de formação continuada que são ministrados para fins de promoção.

Mas, por se tratar de temas atinentes ao sistema carcerário, essa pesquisa também necessitava de autorização do Comitê de Ética. De acordo com a SAP, todas as pesquisas que se relacionam com o sistema carcerário devem ser autorizada pela Administração Penitenciária.

Sendo assim, com o prazo correndo e ficando cada vez mais exíguo, foi apresentada, para fins de exame de qualificação, uma pesquisa de análise jurisprudencial, como será explicado no capítulo 3, quando será retratada a metodologia utilizada. Em discussão durante a banca de qualificação, os professores presentes concordaram que para melhor se alcançar o objetivo pretendido pela pesquisa seria mais interessante entrevistar os juízes de execução do que analisar decisões judiciais. Para tanto, por envolver seres humanos, seria necessária uma autorização do Comitê de Ética, o que inviabilizaria a pesquisa em razão do prazo. Deste modo, os professores presentes consignaram em ata que a pesquisa estava dispensada da autorização do Comitê de Ética, uma vez que não seriam investigados temas pessoais e nem seria exposta a identidade de nenhum dos entrevistados. Os temas que seriam abordados pertencem ao âmbito profissional do juiz e, portanto, são temas de caráter público por excelência. Ademais, não se fariam perguntas pessoais aos juízes nas entrevistas e apenas perguntas sobre a percepção e valoração do Poder Judiciário sobre os agentes penitenciários.

Logo após o exame de qualificação, deu-se início à construção do roteiro de entrevistas semidirigidas a ser utilizado na pesquisa. Os passos seguidos a partir de então estão pormenorizados no capítulo 3.

Contudo, se faz importante uma pequena análise do percurso: nota-se um evidente fechamento do sistema penitenciário para o mundo exterior. Isso se dá em diversos ângulos. Apenas juízes das Varas da Execução Penal, membros do Ministério Público, membros da Defensoria Pública, membros do Conselho da Comunidade, membros do Conselho Nacional de Política Criminal Penitenciária, membros das entidades que prestam 
assistência religiosa e familiar em dias de visita podem ingressar nas unidades prisionais do Estado. Organizações de defesa de Direitos Humanos têm seu ingresso impedido. A imprensa tem sua entrada proibida. Até mesmo o Conselho Nacional de Política Criminal Penitenciária teve suas inspeções restringidas, sob alegação de falta de segurança ${ }^{28}$.

A criação do Comitê de Ética da SAP pode também ser utilizado como mais uma forma de controle das informações que podem se tornar públicas sobre o sistema penitenciário paulista. A tendência ao fechamento não é exclusividade do sistema penitenciário paulista e sim da instituição Prisão por excelência. Contudo, tal fechamento pode também ser utilizado para legitimar abusos e esconder irregularidades.

O sistema penitenciário é uma instituição pública e deve estar sujeito às regras da transparência típicas das instituições republicanas. Não se pode violar, sob o argumento da disciplina e da segurança, os princípios mais caros à democracia e ao Estado Democrático de Direito. Tais princípios são conquistas sociais que custaram muito caro à nossa sociedade e não podem ser ignorados por nenhum órgão público, principalmente pelo responsável por custodiar aqueles que estão temporariamente excluídos do convívio social, por terem rompido, ao menos em tese, o contrato social, ao ferir normas de alto valor ${ }^{29}$.

\footnotetext{
${ }^{28}$ Conselho Nacional de Política Criminal Penitenciária. Relatório sobre inspeção nos estabelecimentos penais do Estado de São Paulo. 2011. Disponível em: <http://portal.mj.gov.br>. Acesso em: 21 nov. 2012.

29 ADRIANA TAETS se propôs a entrevistar agentes penitenciárias para sua dissertação de mestrado apresentada em 2012, no Departamento de Antropologia Social da USP. Ela apresentou uma análise similar a esta: “A recusa de muitas mulheres em participar da pesquisa aponta, também, para uma instituição que se mantém fechada, permanecendo opaca e impedindo a construção de um saber sobre si”. TAETS, Adriana Rezende Faria. Abrindo e fechando celas: narrativas, experiências, e identidades de agentes de segurança penitenciária femininas. 2012. Dissertação (Mestrado em Antropologia Social) - Faculdade de Filosofia, Letras e Ciências Humanas, Universidade de São Paulo, São Paulo. 2012. p. 33.
} 
Capítulo 2

\section{O OLHAR DA LITERATURA ACADÊMICA:}

\section{ESTADO DA ARTE}

Este capítulo destina-se a colocar em relevo a bibliografia de referência que se dedicou à temática dos agentes penitenciários e que serviu de base tanto para a construção do roteiro de entrevista ${ }^{30}$ quanto para a discussão e interpretação dos dados desta pesquisa $^{31}$.

Apresentam-se, aqui, o estado da arte a partir da exposição das ideias centrais de algumas das principais obras que tratam do tema. Serão focalizados, em ordem cronológica, a obra de Donald Clemmer; Erving Goffman; Gresham M. Sykes; Augusto Thompson; Kelsey Kauffman; Antoinette Chauvenet, Françoise Orlic e Geroges Benguigui; Luiz Antônio Bogo Chies; Pedro Rodolfo Bodê de Moraes; Anderson Moraes de Castro e Silva; Adriana Taetz e a obra cinematográfica "A Experiência”, baseada no experimento de Zimbardo.

\footnotetext{
${ }^{30}$ Vide infra capítulo 3.

${ }^{31}$ Foram lidos, também, para auxiliar a compreensão do complexo mundo do sistema prisional e dos agentes penitenciários, bem como para fundamentar criminologicamente o trabalho, as seguintes obras: ALVAREZ, Marcos César; SAlLA, Fernando; GAUTO, Maitê. A contribuição de David Garland: a sociologia da punição. Tempo Social, São Paulo, FFLCH/USP, v. 18, n. 1, p. 329-350, jun. 2006. Disponível em: <http://www.fflch.usp.br/sociologia/temposocial/edicoes.php>. Acesso em: 22 set. 2010. BARATTA, Alessandro. Criminologia crítica e crítica do direito penal: introdução à sociologia do direito penal. 3 ed. Rio de Janeiro: Revan, 2002. (Coleção Pensamento Criminológico v. 1). BECKER, Howard S. Outsiders: studies in the sociology of deviance. New York: The Free Press, 1991. CoELHO, Edmundo Campos. A oficina do diabo e outros estudos sobre criminalidade. Rio de Janeiro/São Paulo: Record, 2005. CORRÊA JUNIOR, Alceu; SHECAIRA, Sérgio Salomão. Teoria da pena: finalidades, direito positivo, jurisprudência e outros estudos de ciência criminal. São Paulo: RT, 2002. LEMGruber, Julita; PAIVA, Anabela. A dona das chaves: uma mulher no comando das prisões do Rio de Janeiro. Rio de Janeiro/São Paulo: Record, 2010. MATTOS, Virgilio de. De uniforme diferente: o livro das agentes. Belo Horizonte: Fundação MDC, 2010. DE GIORGI, Alessandro. A miséria governada através do sistema penal. Rio de Janeiro: Revan, 2008. (Coleção Pensamento Criminológico v. 12). GARLAND, David. Punishment in modern society: a study in social theory. Oxford: The University of Chicago Press, 1993. GARLAND, David. The culture of control: rime and social order in contemporary society. Chicago: The University of Chicago Press, 2001. JESUS, Maria Gorete Marques de. O crime de tortura e a justiça criminal: um estudo dos processos de tortura na cidade de São Paulo. São Paulo: IBCCRIM, 2010. (Monografias IBCCRIM n. 55). KIRCHHEIMER, Otto; RusCHE, Georg. Punição e estrutura social. 2. ed. Rio de Janeiro: Revan, 2004. (Coleção Pensamento Criminológico v. 3). SÁ, Alvino Augusto de. Direitos humanos e execução penal. In: BITTAR, Eduardo C. B. (org.). Educação e metodologia para os direitos humanos. São Paulo: Quartier Latin, 2008.
} 


\subsection{DonAld CLEMMER - The Prison Community ${ }^{32}$}

The Prison Community é um dos livros clássicos e essenciais para a compreensão da Instituição Prisão. Apesar de ter sido escrito na década de 1930, nos EUA, ele nos diz muito sobre a estrutura social prisional que ainda persiste. Claro que muito mudou - como as taxas de encarceramento e as justificativas para a utilização da pena privativa de liberdade -, porém, a obra de CLEMMER ainda diz muito sobre a Instituição Prisão, que não deixou de existir, pelo contrário, passou a ser cada vez mais fortalecida e utilizada.

DONALD CLEMMER ${ }^{33}$ foi um dos primeiros pesquisadores a estudar, do ponto de vista sociológico, a efetividade e a eficiência da Organização Prisão. Ele apresenta o conceito de organização formal e organização informal de uma prisão. Ademais, ele traz a noção de que os eventos que ocorrem nas fábricas, hospitais e prisões só ocorrem porque existe um local organizacional para $\operatorname{tal}^{34}$.

Clemmer aborda a questão do fenômeno que denomina de assimilação ou prisionalização ${ }^{35}$. Segundo ele, a assimilação implica um processo de aculturação, ou seja, que um grupo adquira características similares a um outro. Em suas palavras, "o termo assimilação descreve um processo lento, gradual, mais ou menos inconsciente, durante o qual a pessoa aprende o bastante sobre a cultura de uma unidade social em que foi alocada para fazer parte característica dela”36. De acordo com ele, todos que entram nas prisões sofrem o processo de prisionalização por serem submetidos aos fatores universais de prisionalização $^{37}$.

\footnotetext{
${ }^{32}$ Clemmer, Donald. The prison community. 2 ed. New York: Holt, Rinehart \& Winston, 1958.

33 CLEMMER trabalhou como sociólogo na equipe de saúde mental. Essa equipe era composta por um psiquiatra, um psicólogo, um médico e um sociólogo. Idem, p. XVI.

${ }^{34}$ Idem, p. VII.

${ }^{35}$ Idem, p. 298-304.

${ }^{36}$ Do original: “(...) the term assimilation describes a slow, gradual, more or less unconscious process during which a person learns enough of the culture of a social unit into which he is placed to make him characteristic of it”. Idem, p. 299.

${ }^{37}$ Do original: “Universal factors of prisonization". Idem, p. 300.
} 


\title{
2.2 Erving GoffMAn - Manicômios, Prisões e Conventos ${ }^{38}$
}

Para compreender melhor os agentes penitenciários, é necessário considerar as características de instituição total das penitenciárias, de que nos fala GOFFMAN, em sua obra de 1961. Este conceito está presente, direta ou indiretamente, em diversas teses e dissertações brasileiras que tratam de questões relacionadas ao cárcere ${ }^{39}$.

O autor apresenta logo no primeiro parágrafo do livro a definição de instituição total:

\begin{abstract}
Uma instituição total pode ser definida como um local de residência e trabalho onde um grande número de indivíduos com situação semelhante, separados da sociedade mais ampla por considerável período de tempo, levam uma vida fechada e formalmente administrada. ${ }^{40}$
\end{abstract}

Ou ainda: “Característica central das instituições totais é o fato de que 'todos os aspectos da vida são realizados no mesmo local e sob uma única autoridade’,41.

GOFFMAN, ao analisar as características gerais dessa espécie de instituição, assevera que "toda instituição tem tendência de 'fechamento","42, porém quanto às instituições totais:

seu ‘fechamento’ ou seu caráter total é simbolizado pela barreira à relação social com o mundo externo e por proibições à saída que muitas vezes estão incluídas no esquema físico - por exemplo, portas fechadas, paredes altas, arame farpado, fossos, água ou pântanos. ${ }^{43}$

Tais instituições, por terem regras muito peculiares de funcionamento, propiciam a formação de comportamentos padronizados dentre aqueles que estão submetidos a elas, operando-se o efeito denominado de mortificação do eu.

\footnotetext{
${ }^{38}$ Goffman, Erving. Manicômios, prisões e conventos. 7. ed. São Paulo: Perspectiva, 2005.

${ }^{39}$ Contudo, atualmente, no Brasil, pode-se problematizar a aplicação direta e irrestrita deste conceito para as unidades prisionais por conta da presença das facções criminosas, ao menos nos Estados de São Paulo e do Rio de Janeiro; da corrupção dos agentes públicos e das constantes negociações que ocorrem extraoficialmente no cotidiano prisional. Porém, de forma alguma este conceito deve ser descartado ou está superado: ele é fundamental para a compreensão de diversos aspectos da Instituição Prisão.

${ }^{40}$ GOFFMAN, Erving. Op. cit., p. 11.

${ }^{41}$ Idem, p. 17.

${ }^{42}$ Idem, p. 16.

${ }^{43}$ Ibidem.
} 
São diversos os processos de mortificação do eu descritos na obra de GOFFMAN: as cerimônias de ingresso na instituição, perda do nome - substituído por apelidos que ganha da equipe técnica e dos outros que já estão ali -, submissão, perda da disponibilidade de decidir quando e como atuar mesmo em atos corriqueiros do cotidiano, perda da aparência usual e dos utensílios com os quais mantém essa aparência, adoção de posturas físicas e verbais humilhantes, dentre outros. Para sobreviver, o internado cria mecanismos de adaptação: táticas de enfrentar a tensão entre o mundo original e o mundo institucional ${ }^{44}$.

Por serem instituições totais, deve-se considerar que não apenas os encarcerados são submetidos aos seus efeitos - talvez eles o sejam em maior grau, por não saírem em nenhum momento da vida intramuros -, porém, os agentes penitenciários também sofrem influência desta instituição. A instituição total opera efeitos sobre os agentes e eles reagem operando efeitos sobre a instituição, constituindo-se uma relação dialética.

GOFFMAN descreve que "o pessoal da equipe dirigente precisa enfrentar a hostilidade e as exigências dos internados, e geralmente precisa apresentar aos internados a perspectiva racional defendida pela instituição" 45 , de tal sorte que a maneira pela qual eles desempenham tal função complexa e ambígua se relaciona com os demais elementos presentes na instituição, já que existe uma contradição entre as finalidades declaradas e o que a instituição realmente alcança. Tal contradição está muito presente no cotidiano profissional dos $\mathrm{ASPs}^{46}$.

Além disso, cada grupo social que convive na instituição total "tende a conceber o outro através de estereótipos limitados e hostis” ${ }^{47}$, principalmente pelo fato de terem contato restrito ao mínimo necessário para desempenharem suas funções. Deste modo, acabam por se desenvolver dois mundos sociais distintos e marcados entre os presos e os guardas $^{48}$. Estes dois mundos se cruzam, porém não se interpenetram ${ }^{49}$.

GOFFMAN acrescenta um elemento bastante interessante para a compreensão do mundo da equipe dirigente: a questão de terem que seguir alguns padrões humanitários. Para ele, “a obrigação da equipe dirigente quanto à manutenção de alguns padrões humanitários de tratamento para os pacientes apresenta problemas específicos, mas

\footnotetext{
${ }^{44}$ Idem, p. 23-49.

45 Idem, p. 77.

${ }^{46}$ Idem, p. 70-71.

${ }^{47}$ Idem, p. 19.

${ }^{48}$ Idem, p. 20.

49 Mais uma vez aqui cabe questionar a dimensão desta afirmação nas prisões brasileiras do século XXI, em razão dos elementos da corrupção, facções criminosas e negociações extraoficiais.
} 
encontramos outro conjunto de problemas característicos no constante conflito entre padrões humanitários, de um lado, e eficiência da instituição, de outro” ${ }^{50}$.

GOFFMAN também apresenta as divergências entre os guardas e os técnicos nas instituições totais. São contratados especialistas para a realização dos objetivos declarados e oficiais do estabelecimento, porém assevera que uma queixa clássica destes é de que não podem desempenhar seu trabalho de forma adequada. Deste modo, acabam por chancelar os objetivos da segurança e disciplina ao não conseguirem realizar suas tarefas e terem seus títulos de especialistas utilizados para dar a falsa ideia, para a sociedade, de que os aprisionados podem contar com essa assistência técnica ${ }^{51}$.

\subsection{GRESHAM M. SYKES - The Society of Captives}

SYKES realiza seu estudo, publicado pela primeira vez em 1971, na Penitenciária Estadual de New Jersey (New Jersey State Prison), nos Estados Unidos.

O autor apresenta as dificuldades enfrentadas pelos custodiadores (custodians) no seu exercício profissional. Um dos pontos levantados é a dificuldade em definir quais meios podem ser utilizados para manter a ordem e evitar atos desviantes nas unidades prisionais $^{52}$.

Além disso, a atividade mais ambígua enfrentada pelos agentes de segurança é a de transformar “criminosos” em “não criminosos”. Em seus dizeres temos que:

\footnotetext{
De todas as tarefas que cabe à prisão realizar, nenhuma é mais ambígua do que a tarefa de transformar criminosos em não criminosos. O objetivo em si está longe de ser claro e, mesmo quando se chega a um acordo sobre ele, como mencionamos anteriormente, os meios para alcançá-lo continuam incertos. ${ }^{53}$
}

\footnotetext{
${ }^{50}$ GOFFMAN, Erving. Op. cit., p. 73.

${ }^{51}$ Idem, p. 83.

52 SYKES, Gresham. The society of captives: a study of a maximum security prison. New Jersey: Princeton University Press, 1974. p. 17.

53 Tradução livre da autora. Do original: "Of all the tasks which the prison is called upon to perform, none is more ambiguous than the task of changing criminals into noncriminals. The goal itself is far from clear and even when agreement can be reached on this point, as we have mentioned before, the means to achieve remain uncertain”. Ibidem.
} 
O autor apresenta e discute as contradições dentre as finalidades da pena de prisão e assevera que os custodiadores têm clareza de que, em primeiro lugar, devem garantir que não ocorram fugas e nem rebeliões ${ }^{54}$. Neste sentido, além de ter que estar sempre atento para prevenir qualquer ação que possa resultar em fuga, o guarda deve auxiliar na construção de muros psicológicos que desestimulem o preso (cativo - captives) de fugir.

Somado às medidas de prevenção consideradas mais óbvias, como revistar celas em busca de objetos ilícitos; contar, com frequência, os presos para checar se estão todos presentes nas celas que deveriam estar; censurar correspondências que possam se relacionar com planos de fuga e inspecionar as grades e outras possíveis rotas de fuga; os custodiadores devem preocupar-se com ações que possam parecer inocentes. São exemplos dados pelo autor: pimenta roubada do refeitório pode ser uma arma ao ser jogada nos olhos do guarda, um preso que deixa crescer um bigode pode estar querendo se disfarçar melhor quando estiver do outro lado do muro etc. ${ }^{55}$

Com relação à manutenção da ordem interna, o autor acrescenta que as dificuldades estão relacionadas com as condições de vida impostas aos presos. Condições de vida, estas, que cabem aos agentes impor.

Ademais, os guardas devem assegurar o cumprimento das leis que são válidas nas sociedades livres - como a proibição de matar, roubar etc. - e, somado a isso, devem assegurar que as regras peculiares das prisões também sejam cumpridas. Estas normas internas dizem respeito às regras de convivência e de comportamento dentro das prisões, como a proibição de andar em determinados setores das unidades, ter que andar com as mãos para trás e a cabeça para baixo etc. ${ }^{56}$

É interessante a observação do autor de que os presos são colocados nas prisões não para serem punidos, mas como forma de punição. Por detrás desta afirmação está a noção de que os custodiadores não devem infligir mais dor ou sofrimento aos presos, além daqueles inerentes ao fato de estarem privados de liberdade ${ }^{57}$. Se isso for verdadeiro, por que as regras que devem ser seguidas dentro das prisões são tão estritas? SYKES diz que de acordo com diversos presos, os custodiadores gostariam de puni-los e de infligir

\footnotetext{
${ }^{54}$ Idem, p. 18.

${ }^{55}$ Idem, p. 21.

${ }^{56}$ Idem, p. 22-23.

57 No original: "It is sometimes said that criminals are placed in prison not for punishment but as punishment; presumably, stress is being placed on the idea that the officials of the custodial institution are determined not to hurt their captives either physically or mentally beyond the pain involved in confinement itself.” Idem, p. 31.
} 
sofrimento aos presos, porém não podem fazer isso de uma maneira declarada. Por isso, criam e aplicam regras muito rígidas e utilizam o argumento de que o fazem em nome da segurança e da ordem interna, quando na verdade esta é a forma que encontraram de punir os cativos $^{58}$.

O autor salienta, no entanto, que não se pode afirmar que o desejo de retribuição é a motivação primeira para que sejam aplicadas essas regras restritivas, já que o objetivo de garantir a ordem interna e a segurança é realmente a prioridade dos custodiadores ${ }^{59}$.

Mais adiante, analisa a tarefa de reformar os presos. Segundo ele, apesar das unidades contarem com psicólogos, professores e outros profissionais, esse objetivo mantém-se apenas no discurso e não é realmente colocado em prática por meio de um programa coerente. Trata-se de uma expressão de esperança, apenas ${ }^{60}$.

SYKES afirma que os funcionários da penitenciária de segurança máxima de New Jersey criaram uma ordem social que deveria, ao menos em teoria, minimizar as possibilidades de fugas e de confusão dentro dos muros.

A retribuição proporcional ao delito cometido está muito abaixo na lista de prioridades e a tarefa de reformar é, talvez, a última da lista, ao menos, é claro, se o melhor caminho para a reabilitação for o cumprimento das normas internas ${ }^{61}$.

\subsection{Augusto Thompson - A Questão Penitenciária}

Em 1976, Augusto Thompson escreveu A Questão Penitenciária. Em 2000 publicou uma edição revista e ampliada da obra. O autor teve vasta experiência de trabalho em penitenciárias, como advogado e como diretor de estabelecimento prisional no Estado do Rio de Janeiro.

Nessa obra, THOMPSON afirmou que no interior das penitenciárias surgem conflitos advindos da interação entre a ordem oficial e a ordem interna informal e que é por meio de

\footnotetext{
${ }^{58}$ Idem, p. 32.

${ }^{59}$ Idem, p. 33.

${ }^{60}$ Do original: "But allegiance to the goal of rehabilitation tends to remain at the verbal level, an expression of hope for public consumption rather than a coherent program with an integrated, professional staff." Idem, p. 34.

${ }^{61}$ Idem, p. 39.
} 
um processo de acomodação que os conflitos são solucionados ${ }^{62}$. A privação de liberdade como forma de punição penal acabou por gerar um sistema social próprio, uma vez que são criadas comunidades com um grande número de pessoas. De acordo com o autor, o convívio nessas comunidades acaba por gerar regras de convivência próprias, informais, resultantes da interação entre essas pessoas diante das peculiaridades do ambiente em que se encontram ${ }^{63}$.

O autor afirma que uma das características mais marcantes das penitenciárias enquanto sistema social é sua estrutura voltada para ser totalitária. As regulações minuciosas, a vigilância constante e a concentração de poder nas mãos de poucos são elementos que se relacionam diretamente com a característica de um regime de controle total - ou quase total ${ }^{64}$.

THOMPSON destaca as finalidades da prisão - ao menos as declaradas - e afirma que são incongruentes. Ele salienta como finalidades: o confinamento, a ordem interna, a punição, a intimidação particular e geral e a regeneração ${ }^{65}$. O que torna as coisas ainda mais complexas é o fato da estrutura ser limitada pela lei, custodiadores e opinião pública $^{66}$. Mais uma vez, é pertinente aqui acrescentar a questão em torno das facções criminosas e como tal elemento pode contribuir para a reorganização da estrutura que THOMPSON descreveu.

Afirma, ainda, que não é a solidão o que perturba a população penitenciária composta pelos guardas, técnicos, membros da direção e presos - mas, sim, a vida em massa, uma vez que passam a compartilhar uma proximidade estreita com diversas pessoas até então desconhecidas ${ }^{67}$.

O autor traz a presença do processo de assimilação, chamado de prisionalização por DONALD CLEMMER, como fundamental para a vida prisional. De acordo com ele,

\footnotetext{
${ }^{62}$ ThOMPSON, Augusto. A questão penitenciária. 5 ed. Rio de Janeiro: Forense, 2002. p. 20.

${ }^{63}$ Idem, p. 21.

${ }^{64}$ Idem, p. 22. Pode-se questionar se este pensamento de THOMPSON aplica-se com perfeição ao atual sistema penitenciário brasileiro. A presença marcante das facções criminosas, ao menos nos Estados de São Paulo e do Rio de Janeiro, agregam elementos para a discussão do contexto do estabelecimento da ordem totalitária. A forte presença das facções atua na redistribuição do poder, influenciando este equilíbrio de forma intensa. Além disso, há o elemento da corrupção. Não temos dados sobre a quantidade de agentes penitenciários e demais funcionários da administração prisional envolvidos com a corrupção; porém, com a existência desta entre os agentes públicos do poder totalitário e o equilíbrio de forças e de submissão, as regras se alteram.

${ }^{65}$ Ibidem.

66 Ibidem.

${ }^{67}$ Idem, p. 23.
} 
o termo prisionalização indica a adoção, em maior ou menor grau, do modo de pensar, dos costumes, dos hábitos - da cultura geral da penitenciária. Prisionalização é semelhante à assimilação, pois todo homem que é confinado ao cárcere sujeita-se a prisionalização, em alguma extensão. ${ }^{68}$

THOMPSON coloca os fatores universais da prisionalização, que formam a base da pesquisa que será a seguir exposta, realizada sob a coordenação de LUIS BoGo CHIES ${ }^{69}$. Esses fatores universais de prisionalização, deixa claro o autor, não são incorporados em sua totalidade e no mesmo grau por todas as pessoas, mas, certamente, todos sofrem influência de tais elementos.

Os fatores universais de prisionalização são: aceitação de um papel inferior; acumulação de fatos concernentes à organização da prisão; o desenvolvimento de novos hábitos no comer, vestir, trabalhar, dormir; adoção do linguajar local; o reconhecimento de que nada é devido ao meio ambiente quanto à satisfação de necessidades; eventual desejo de arranjar uma "boa ocupação"70.

Argumenta que, provavelmente, a personalidade do preso se desorganiza de tal sorte que torna difícil a adaptação à vida livre em sociedade novamente ${ }^{71}$.

O autor acrescenta que os guardas também sofrem, em algum grau, o processo de prisionalização, sendo que se tentassem "carregar os valores da sociedade livre para a comunidade prisional, tentando impô-los ali, entrariam em choque com a instituição e, provavelmente, ou a levariam ao caos ou seriam ejetados do sistema”72. Essa é uma possível explicação, bastante interessante, para algumas atitudes do corpo dirigente que não seriam aceitáveis no mundo fora das prisões, mas são permitidas, e talvez até corriqueiras, no mundo dentro das prisões ${ }^{73}$. A pesquisa coordenada por CHIES trata exatamente de investigar a ocorrência, ou não, desse processo de prisionalização dentre os agentes penitenciários.

O relacionamento entre presos e membros da administração prisional proporcionado pelo convívio estreito e pela interação, em alguns casos intensa, dentro das

\footnotetext{
${ }^{68}$ Ibidem.

${ }^{69}$ CHIES, Luiz Antônio Bogo et al. A prisionalização do agente penitenciário: um estudo sobre encarcerados sem pena. Pelotas: Educat, 2001.

${ }^{70}$ ThOMPSON, Augusto. Op. cit., p. 24.

${ }^{71}$ Idem, p. 25.

${ }^{72}$ Idem, p. 27.

${ }^{73}$ Ibidem.
} 
prisões, faz com que haja influência recíproca entre essas pessoas com papéis distintos a cumprir $^{74}$.

No que diz respeito à direção da penitenciária, THOMPSON assevera que o primeiro passo fundamental que demonstra o processo de prisionalização sofrido pelo diretor é quando esse escolhe a lista de prioridades no que concerne aos fins visados pela instituição que está sob seu comando. Com a escolha das prioridades, a prisionalização do grupo dirigente se consuma, de acordo com ele. Sendo que, a partir de então, suas ações e, também sua equipe, serão orientadas substancialmente para esses fins eleitos como prioritários $^{75}$.

As prioridades elencadas pelo autor são:

As metas sérias da prisão são evitar fugas e manter a ordem interna. As demais, sobretudo a referente à recuperação ficam em plano inferior, ou abandonadas ou adiadas para quando aquelas forem definitivamente resolvidas (o que na prática significa adiá-las ad eternum). Cumpre manter um equilíbrio entre guardas e internos, através de uma justiça impessoal, padronizada e objetiva - onde impessoal quer dizer igualitária, no sentido mais grosseiro do termo; padronizada significa assunção dos padrões fornecidos pela comunidade carcerária; e objetiva implica atender aos princípios regulamentares ao pé da letra. ${ }^{76}$

No que diz respeito aos guardas, THOMPSON afirma que estão inseridos no sistema hierárquico, sendo uma peça chave da representação do poder, apesar de não possuírem poder decisório, devendo se submeter à direção. Por outro lado, não adotam a postura descompromissada dos condenados, já que são responsáveis pelo bom funcionamento das prisões. Dessa maneira, cabe aos agentes obedecer às ordens e fazer com que os presos obedeçam a elas, para assim conseguir manter a prisão "tranquila"77. Do ponto de vista formal, cabe à direção o papel de "legislar” e “julgar” e, aos agentes penitenciários, o papel de "executar" 78 .

Segundo THOMPSON, a inferioridade numérica dos guardas e a pressão, que parte tanto da equipe dirigente quanto da sociedade, faz com que seus objetivos passem a ser: i)

\footnotetext{
${ }^{74}$ Idem, p. 25-26.

${ }^{75}$ Idem, p. 33.

${ }^{76}$ Idem, p. 38-39.

${ }^{77}$ Idem, p. 40.

${ }^{78}$ Ibidem.
} 
punir; ii) intimidar e iii) regenerar ${ }^{79}$. Esse ponto específico foi objeto de investigação da pesquisa coordenada por CHIES, que perguntou aos agentes qual era a função da cadeia, na visão deles e na visão da sociedade ${ }^{80}$.

O objetivo de manter a cadeia sem rebeliões e motins, sem se preocupar com as finalidades da pena relativas à reinserção social do condenado se transforma em prioritário. Essa preocupação primeira de garantir a ordem na prisão é legitimada, também, pelas incongruências entre as finalidades da pena e o aparato repressivo. Essas incongruências são vivenciadas pelo grupo de profissionais, que passam a se sentir legitimados a adotar as posturas que lhes forem mais convenientes ${ }^{81}$. Deste modo, os meios se tornam os fins, “passando os fins a servir, tão-somente, para justificar as medidas julgadas necessárias para a realização daqueles meios-que-se-tornaram-fins" ${ }^{\text {82 }}$.

De acordo com Thompson, o fato de serem inferiores numericamente e de trabalharem desarmados faz com que os agentes tenham dificuldade em impor violência corporal contra os presos. Neste sentido, o instrumento mais eficaz para a consecução desse objetivo é a influência que exercem na distribuição de punições e recompensas ${ }^{83}$.

Em razão da falta de pessoal e da necessidade de contar com o trabalho dos presos para conseguirem cumprir todas as suas atribuições, se cria uma relação de dependência entre os ASPs e os internos. Neste sentido, os favores de caráter omissivo são fundamentais para conseguir manter a cadeia "mansa" ${ }^{84}$.

De acordo com Thompson, os elementos abordados em sua pesquisa podem explicar porque a tendência dos ASPs não é de se tornarem "tiranos brutais”, mas sim “servidores corruptos" 85 .

Outro ponto interessante para a compreensão do papel do ASP na complexidade da estrutura social das penitenciárias é a sua relação com os técnicos, em especial com os psicólogos. A finalidade primeira do trabalho dos dois grupos é distinta: como já foi dito, a do ASP é a manutenção da ordem na cadeia; a do psicólogo é a regeneração do preso ${ }^{86}$.

\footnotetext{
${ }^{79}$ Idem, p. 41.

${ }^{80}$ CHIES, Luis Bogo et al. Op.cit., p. 56-59.

${ }^{81}$ ThOMPSON, Augusto. Op. cit., p. 43.

${ }^{82}$ Ibidem.

${ }^{83}$ Idem, p. 46.

${ }^{84}$ Idem. p. 51.

${ }^{85}$ Idem, p. 52.

${ }^{86}$ Idem, p. 54.
} 
Desta forma, existe uma desconfiança entre os dois grupos. Para os psicólogos, eles não conseguem atingir os resultados que almejam sem uma atmosfera mais permissiva. Para os ASPs, a instituição se transformará em um caos se o ritmo que se impõe for quebrado, nos dizeres do próprio autor:

\begin{abstract}
Aqueles requerem tratamento especial para cada paciente sob seus cuidados, de acordo com a psicologia particular de cada um; estes respondem que, se a rotina prisional for perturbada, com a adoção de regimes diversos para cada indivíduo, a disciplina ficará irremediavelmente comprometida. ${ }^{87}$
\end{abstract}

\title{
2.5 KelSEY KAUfFMAN - Prison Officers and their World ${ }^{88}$
}

KeLSEy KaUfFMAn foi, ela própria, agente penitenciária na unidade feminina de Niantic, em Connecticut, nos EUA, na década de 1970. Neste período, em que a pesquisadora trabalhou nesta prisão, ela era atípica, pois era regida por regras democráticas em que se faziam reuniões entre as presas e os funcionários para definir as regras do presídio. Todos tinham direito a voto e cada voto tinha o mesmo peso no cômputo final ${ }^{89}$. Era uma unidade pequena, que tinha 30 presas e seis funcionários ${ }^{90}$.

Contudo, de acordo com a autora, mesmo sendo uma unidade considerada atípica, os funcionários - incluindo ela - tinham os mesmo problemas dos agentes penitenciários de outras unidades.

A autora chegou à conclusão, após ter trabalhado como ASP, que os funcionários dos presídios são mal interpretados pela população em geral. Esse foi um dos fatores de motivação para que realizasse a pesquisa.

Ela entrevistou 60 agentes penitenciários que trabalhavam nas quatro maiores penitenciárias masculinas dos EUA: a penitenciária de segurança máxima Walpole; a penitenciária de segurança média Norfolk; o reformatório Concord para jovens adultos e o hospital estadual para “criminosos loucos" ${ }^{91}$ Bridgewater.

\footnotetext{
${ }^{87}$ Ibidem.

${ }^{88}$ KaUfFMAN, Kelsey. Op. cit.

${ }^{89}$ Tradução livre da autora. Do original: “One person (inmate or officer), one vote”. Idem, p. 3.

90 Ibidem.

91 Tradução livre da autora. Do original: “Criminally insane”. Idem, p. 1.
} 
As entrevistas foram realizadas no período compreendido entre os anos 1976 e 1980, com o intuito de analisar a vida dentro do sistema prisional, durante uma década, a partir da perspectiva dos agentes penitenciários, um grupo chave dentro do sistema penitenciário, de acordo com a autora ${ }^{92}$.

Em sua análise, os ASPs são, ao mesmo tempo, agentes e vítimas do sistema penitenciário desumano, mas não seus arquitetos ${ }^{93}$.

A pesquisadora chega à interessante conclusão de que os ASPs entendem que seu trabalho tem por objetivo evitar fugas e manter a ordem interna. A "porta giratória”94, termo usado para se referir à alta reincidência dos presos e seu consequente retorno às prisões, fez com que perdessem a ilusão de que estavam ali para deter crimes ou reduzir a criminalidade $^{95}$.

Para conseguir esses dois objetivos, o ASP dispõem de seis maneiras de expressar e impor seu poder ${ }^{96}$ frente aos presos: autoridade, persuasão, induzimento, manipulação, força e coerção.

A autoridade é a forma de exercício de poder mais econômica e mais desejada, exatamente pelo fato da observância ser automática. Na penitenciária de Norfolk, com o exercício da autoridade, apenas quatro agentes faziam a vigilância de mais de 700 presos soltos no jardim. Os presos reconheciam a autoridade daqueles ASPs e por isso seguiam as regras impostas por eles e obedeciam suas ordens ${ }^{97}$. Um agente entrevistado por KAUFFMAN aborda diretamente essa questão do exercício do poder “via autoridade” ao dizer que, quando um conflito surge com algum preso, "99\% deles iriam retirar-se do conflito, não por mim, mas pela autoridade que estava por trás de mim»98.

A segunda forma de exercício de poder identificada por KAUFFMAN é a persuasão. A persuasão se dá através da utilização de argumentos racionais como forma de convencer os presos a seguirem o que lhes foi dito pelo ASP. Em geral, os argumentos mais utilizados faziam referência às sanções que não estavam no controle do agente aplicar. Nos casos em

\footnotetext{
92 Idem, p. 1-2.

${ }^{93}$ Idem, p. 3.

94 Tradução livre da autora. Do original: “Revolving door”. Idem, p. 46.

95 Ibidem.

${ }^{96}$ A autora define poder como: a habilidade de conseguir que um individuo faça o que se quer, sendo que de outro modo ele não faria. Tradução livre da autora. Do original: "Power is the ability to get an individual to do as one wants when the individual otherwise would not do so.” Ibidem.

${ }^{97}$ Idem, p. 47-52.

${ }^{98}$ Idem, p. 50.
} 
que a sanção estava no âmbito de domínio do agente, aí se tem outra forma de exercício de poder, a coerção ${ }^{99}$.

A indução ou o induzimento dá-se pelo sistema de recompensas. Se o preso obedecer à regra, ganha um pedaço de bolo a mais na refeição, ou uma porção extra de leite, um rolo de papel higiênico ou outras coisas que estão ao alcance do agente fornecer. Mas a indução também pode se dar através de trocas de bens mais valiosos e complexos, como ignorar ofensas cometidas pelos presos, permitir ou auxiliar na entrada de bens proibidos na cadeia (como drogas, por exemplo) e auxiliar na troca de informações entre os presos.

A indução funciona como uma via de mão dupla, as duas partes ganham o que querem. Mas o risco está sempre presente. Um preso que recebeu um pedaço de bolo ou teve a entrada de drogas facilitada hoje, pode denunciar o ASP que possibilitou isso amanhã. Sendo assim, como decorrência direta dessa técnica de exercício de poder, tem-se a chantagem.

Como a prisão é um local onde o equilíbrio é muito frágil, o oferecimento de "favores" em troca de bom comportamento dos presos é muito perigosa, pois os demais presos podem entender aquelas ações como injustas, resultando em mais instabilidade e menos controle, ao contrário do pretendido.

Além disso, os agentes devem tomar cuidado para não serem denunciados por seus colegas ou pelos “favores” realizados aos presos não serem percebidos pelos colegas. Isso pode resultar em expulsão da carreira ou represálias físicas por parte dos próprios colegas $^{100}$.

A manipulação é uma faceta muito importante da vida prisional. Ela ocorre através da utilização de informações enganosas e falsas. Contudo, quando a mentira é revelada, ela resulta em uma grande perda de poder para o $\mathrm{ASP}^{101}$.

Outra forma de imposição do poder é a força. O uso da força está presente em todas as prisões, de acordo com a autora, e é fundamental para limitar a mobilidade e a capacidade de resistência dos presos. Uma forma mais moderna de uso da força apresentado pela autora é a utilização, sem controle médico, de medicamentos fortes e de

\footnotetext{
${ }^{99}$ Idem, p. 52-54.

${ }^{100}$ Idem, p. 54-56.

${ }^{101}$ Idem, p. 56-58.
} 
uso controlado para os presos. Contudo, o uso da força apenas é capaz de fazer com que os presos realizem tarefas simples. Já as tarefas complexas que não são obtidas por meio do uso da força, podem ser garantidas pelo uso da coerção ${ }^{102}$.

A coerção nada mais é do que a utilização de ameaças para a aplicação de sanções. Tais sanções podem ser oficiais - prescritas em lei ou regulamentos - como também podem ser informais - violentas e não violentas.

Existe uma percepção por parte dos ASPs de que os tribunais não podem solucionar os problemas e conflitos que existem dentro de unidade prisional entre os agentes e os presos. Uma fala transcrita pela autora de uma das entrevistas evidencia esse elemento: “ $\mathrm{O}$ tribunal não vai fazer nada. Nada. Nada!”103. Baseados e motivados por essa crença, os ASPs passam a depositar sua confiança em um sistema interno de sanções.

De acordo com os entrevistados, o ASP que segue com frequência o procedimento formal fica mal visto, pois esse seria um indicativo de que ele não consegue manter o controle.

Nota-se que há não apenas uma descrença nas soluções dadas pelo Poder Judiciário: mais do que isso, há uma visão de que optar por soluções oficiais é desmoralizante e significa que o ASP é fraco e não consegue alcançar seus objetivos.

As sanções informais não violentas consistem em deixar o preso trancado na cela por mais tempo que os demais ${ }^{104}$, corte da água quente e da luz elétrica, racionamento de papel higiênico ou de comida.

De acordo com a literatura citada pela pesquisadora, as crueldades e as práticas de tortura cometidas pelos ASPs contra os presos eram regra no século XIX e início do século $\mathrm{XX}$, tendo sua utilização reduzida de modo brutal ao longo do século XX.

Contudo, em duas das penitenciárias estudadas por KAUfFMAN, a prática de violência física manteve-se constante e habitual. Os ASPs entrevistados relataram que se não utilizassem da violência física, seriam os presos que estariam controlando a unidade.

A autora apresenta uma análise interessante de que a coerção é um método de imposição do poder muito falha, uma vez que existe uma escalada constante na gravidade

\footnotetext{
102 Idem, p. 58-61.

103 Idem, p. 62.

${ }^{104}$ Segundo os ASPs entrevistados pela autora, quinze dias de isolamento - sanção prevista na ordem formal - não é nada para os presos.
} 
das punições. Uma sanção usada muitas vezes perde o efeito. Porém, o problema toma uma proporção muito grande quando não existem mais degraus a serem subidos na escala das gravidades das sanções aplicadas ${ }^{105}$.

Ao mesmo tempo em que os ASPs utilizam essas seis formas de exercício do poder para controlar os presos, os presos também utilizam essas técnicas para controlar os agentes penitenciários. Além disso, os presos também exercem o poder contra os outros presos. Em geral, os presos têm mais medo das sanções aplicadas por outros presos do que pelos agentes de segurança penitenciária ${ }^{106}$.

O que a autora demonstra em sua obra é que as seis formas de imposição do poder de que os ASPs lançam mão para alcançar seus objetivos - de evitar rebeliões e manter a “casa em ordem” - são muito falhas e não atingem a meta de manutenção do controle ${ }^{107}$.

A partir das entrevistas realizadas, a autora pode captar o “Código de Conduta” dos $\operatorname{ASPs}^{108}$.

De acordo com ela, os agentes penitenciários possuem uma subcultura diversa daquela adotada pelos presos. Nessa subcultura, existem regras e punições para o seu descumprimento. Todas as normas se fundamentam na solidariedade entre o grupo e estão baseadas na noção de que, sozinho, o ASP não conseguirá realizar seu trabalho e alcançar seu objetivo, mas, mais do que isso, não irá sobreviver ${ }^{109}$.

Ela apresenta nove normas, em ordem da importância que exercem naquela subcultura, extraídas das entrevistas realizadas. Abaixo, estão as normas resumidas:

1) Sempre ir ao auxílio de outro ASP quando esteja em situação de perigo ${ }^{110}$.

Essa norma foi identificada como a mais importante dentro da subcultura dos agentes penitenciários. É nessa regra que a solidariedade entre os agentes é baseada e constrói o senso de fraternidade entre eles. Para os ASPs que trabalhavam em Walpole, o trabalho era bastante perigoso, mas pelo menos estavam unidos.

\footnotetext{
${ }^{105}$ KaUfFMAN, Kelsey. Op. cit., p. 61-71.

${ }^{106}$ Idem, p. 71-76.

107 No item intitulado "O problema do lixo” (Do original: “The garbage problem”), a autora descreve uma situação muito concreta na penitenciária de Walpole, que deixa evidente a não efetividade das formas utilizadas para exercer o poder. Idem, p. 81-84.

${ }^{108} \mathrm{Na}$ realidade, ela optou por realizar esta análise baseada nas entrevistas com os agentes que trabalhavam na penitenciária de Walpole.

109 KaUfFMAN, Kelsey. Op. cit., p. 85-117.

${ }^{110}$ Tradução livre da autora. Do original: “Always go to the aid of an officer in distress". Idem, p. 86.
} 
Essa norma é tão importante que o agente que descumprir outras normas, mas cumprir esta, será perdoado das outras falhas ${ }^{111}$.

2) Não levar droga para dentro da unidade para um preso usar ${ }^{112}$.

A razão para essa norma ser tão importante é o perigo que levar droga para dentro da unidade para uso dos presos pode gerar para os demais ASPs. As reações dos presos, sob efeito de drogas ou álcool, tornam-se mais imprevisíveis e mais difíceis de serem controladas.

A sanção para o descumprimento dessa norma é severa e pode levar à expulsão do responsável da categoria de agente de segurança penitenciária. A regra três (que será abaixo abordada) proíbe a ação de delatar o companheiro. Porém, a regra dois é tão importante que ela constitui uma exceção à norma três e não há punição para aquele que delatar um companheiro que tenha ingressado com droga para que um preso consuma ${ }^{113}$.

3) Não delatar um ASP para um preso ${ }^{114}$.

Essa regra, comum na grande maioria dos grupos que tem a solidariedade interna como ponto fundamental, tem dois desdobramentos específicos na subcultura dos ASPs de Walpole.

Não delatar um ASP para um preso e não cooperar em uma investigação, ou, mais importante, não testemunhar contra um ASP em algum processo ou procedimento oficial que esteja apurando uma atitude cometida pelo ASP contra um preso.

Em essência esses dois desdobramentos estão muito alinhados e seguem a lógica de não trair um parceiro para o inimigo.

Outro elemento embutido nessa norma é não falar sobre um ASP para um preso. O ideal é que os presos saibam o mínimo possível sobre a identidade e a vida pessoal e profissional dos ASPs ${ }^{115}$.

\footnotetext{
${ }^{111}$ Idem, p. 86-90.

112 Tradução livre da autora. Do original: “Don't 'lug' drugs”. Idem, p. 90.

${ }^{113}$ Idem, p. 90-93.

114 Tradução livre da autora. Do original: “Don’t rat”. Idem, p. 93.

${ }^{115}$ Idem, p. 93-99.
} 
4) Nunca fazer um colega ASP “ficar mal” na frente de um preso ${ }^{116}$.

Um agente não pode ser criticado ou ficar em uma situação embaraçosa na frente dos presos, mesmo que esteja agindo de modo incorreto ou que o outro agente discorde.

As consequências do descumprimento dessa norma são sérias, pois deixa transparecer para os presos (inimigos) que não há solidariedade entre o grupo de agentes e isso leva ao aumento da vulnerabilidade dos ASPs enquanto grupo.

Essa norma não vale apenas para situações mais simples, como se o preso pode ou não fazer um telefonema, por exemplo, mas também para situações de imposição de violência física ou psicológica.

A noção de reciprocidade é inerente a essa norma, pois nenhum ASP gostaria de ser criticado por um colega na frente dos presos e, portanto, ficar desmoralizado ${ }^{117}$.

5) Sempre apoie um ASP em uma disputa com um preso ${ }^{118}$.

Os ASPs devem dar apoio incondicional aos colegas de profissão. Essa norma tem um alcance bem amplo, sendo que os demais ASPs devem se prontificar a testemunhar no mesmo sentido da versão apresentada pelo colega mesmo nas situações em que não tenha presenciado o ocorrido ${ }^{119}$.

6) Sempre apoie as sanções impostas por agentes aos presos ${ }^{120}$.

Essa é uma versão mais específica da norma $n^{0}$ 5, porém, envolve não apenas uma atitude passiva, mas também ativa na aplicação das sanções aos presos. O ponto sensível dessa norma reside na aplicação da força física e da coerção.

Sem a existência dessa norma, a violência praticada pelos presos contra os agentes não poderia ser evitada de forma sustentável, como ocorria em Walpole.

Os ASPs mais novos se sentem impelidos a praticarem violência física para serem aceitos pelo grupo de agentes ${ }^{121}$.

\footnotetext{
${ }^{116}$ Tradução livre da autora. Do original: “Never make a fellow officer look bad in front of inmates”. Idem, p. 99. 
7) Não atue como um preso $^{122}$.

Essa norma proíbe que os ASPs demonstrem empatia ou se identifiquem com os presos. Além de trazer riscos para o grupo de agentes, tal postura demonstra que o ASP está negando a sua identidade de agente de segurança penitenciária e está mudando para o grupo inimigo de presos. Também existem aqueles que agem como se fossem assistentes sociais. Estes também estão descumprindo a regra ao se identificarem com outro grupo que não o seu, de agentes penitenciários ${ }^{123}$.

8) Mantenha a solidariedade entre os ASPs em detrimento dos grupos externos ${ }^{124}$.

A subcultura dos ASPs é basicamente definida pela oposição ao grupo de presos, porém a solidariedade entre os agentes é esperada contra todos aqueles que não são agentes, o que inclui a administração da unidade e a administração penitenciária, representantes da mídia e até mesmo a família dos $\operatorname{ASPs}^{125}$.

Uma frase que apareceu em uma entrevista ilustra bem essa norma: "uma coisa que você aprende é nunca falar sobre a instituição para uma pessoa de fora. Você deve apenas falar com outros agentes” ${ }^{\prime 26}$.

9) Demonstre preocupação por um colega agente ${ }^{127}$.

Essa norma de conduta se desdobra em outras duas, quais sejam: (i) nunca deixe um problema para outro ASP; e (ii) ajude um colega agente com problemas fora da instituição.

Mesmo essa norma tendo sido identificada em teoria, ela é frequentemente desrespeitada, em especial entre os agentes de um turno e os de outro, como se o verdadeiro dever de solidariedade e lealdade não fosse entre os agentes penitenciários da unidade de Walpole, mas, tão somente, entre os agentes penitenciários do mesmo turno ${ }^{128}$.

\footnotetext{
122 Tradução livre da autora. Do original: “Don’t be a white hat”. Idem, p. 108.

123 Idem, p. 108-110.

${ }^{124}$ Tradução livre da autora. Do original: “Maintain officers solidarity versus all outside groups”. Idem, p. 110.

${ }^{125}$ Idem, p. 110-112.

126 Tradução livre da autora. Do original: "One of the things you learn is never talk about the institution to outsiders. You should only talk to the other officers”. Idem, p. 111.

${ }^{127}$ Tradução livre da autora. Do original: "Show positive concern for fellow officers". Idem, p. 112.

${ }^{128}$ Idem, p. 112-114.
} 
Mais adiante a autora aborda os efeitos que o trabalho como agente de segurança penitenciária tem na esfera pessoal desses funcionários. Os impactos são severos ${ }^{129}$.

A maioria dos ASPs entrevistados que estavam em um casamento de poucos anos tiveram seus relacionamentos destruídos. Eles passaram a viver em uma situação de “nervos à flor da pele” tão extrema que não conseguiam mais realizar tarefas simples como ir ao supermercado ou levar os filhos para um passeio no zoológico. Outros passaram a ser viciados em drogas, alguns chegaram ao ponto de ter que se embriagar antes de ir para o trabalho, às sete horas da manhã.

Alguns outros viviam tão nervosos que davam socos nas paredes da sua casa até fazer furos e tratavam mal aqueles que amavam. Além disso, passaram a sofrer de dores físicas, como dores de cabeça muito intensas, hipertensão e a ter pesadelos frequentes. A grande maioria disse se sentir extremamente infeliz e sem ver saída para retomar uma vida boa novamente. Em resumo, o trabalho na prisão afetou todas as facetas da vida dessas pessoas, a saúde, suas personalidades e suas famílias.

O ambiente dentro da prisão, em especial Walpole, era permeado de tensão e ansiedade. Um dos entrevistados relatou que todos os dias os ASPs se envolviam em quatro ou cinco discussões e que "ninguém precisa disso"130.

Entretanto, o que mais chama atenção realmente é que todos relataram sentir medo o tempo todo durante o trabalho, mesmo quando a cadeia estava calma. Não apenas aqueles vítimas de alguma agressão, mas todos aqueles que presenciaram fatos assustadores.

Um dos entrevistados disse:

Eu tinha medo. Todos os dias eu tinha medo de ir para o trabalho. Eu realmente tinha medo. Eu ficava petrificado. À noite, eu tinha insônia e tinha pesadelos preocupado com o que poderia acontecer... Apenas entrar lá todas as manhãs, você não sabe o que esperar, de verdade. Você não sabe o que iria acontecer... Eu ficava extremamente infeliz e com muito medo. ${ }^{131}$

\footnotetext{
${ }^{129}$ Idem, p. 212-243.

${ }^{130}$ Idem, p. 214.

131 Tradução livre da autora. Do original: "I was scared. Every day I was scared to go to work. I really was. I was petrified. At night I had sleepless nights and I had nightmares worrying what would happen...Just walking in there in the morning, you didn't know what to expect, really. You didn't know what was going to happen... I was really miserable and I was scared”. Idem, p. 217.
} 
Além disso, eles relataram não poder demonstrar seus sentimentos, em particular, o medo.

No que diz respeito aos impactos físicos, além dos machucados provocados pelos presos, os ASPs relataram terem adquirido, após o ingresso na carreira, problemas de pressão alta, problemas cardíacos, dores de cabeça intensas e persistentes e vista embaçada.

Ainda segundo a pesquisa, o trabalho é extremamente fatigante e consome todas as energias. Muitos agentes acham que a única forma de esquecer o mundo da prisão quando não se está em serviço é beber ou usar outras drogas. Muitos têm consciência dessa situação, mas não conseguem imaginar como alterar essa realidade enquanto trabalharem em prisões.

Ademais, ainda existem os dilemas morais que devem ser sanados todos os dias. Os agentes entrevistados identificaram um antagonismo entre os valores individuais e o que era esperado de um agente penitenciário. Com o passar do tempo e com o aumento do envolvimento com o mundo prisional, os agentes começam a neutralizar seus próprios sentimentos de culpa ao compreender a prisão como um mundo à parte regido por outros valores e, também, percebem os presos como indivíduos que estão fora da esfera de proteção das regras da moral. “Isso é uma prisão, não é a sociedade. Quando você pisa aqui dentro, você pisa em um mundo diferente”, disse um dos agentes entrevistados pela autora $^{132}$.

As pessoas que nunca haviam presenciado cenas de violência e foram trabalhar nas prisões sofrem um choque muito grande, sendo indiferente quem era a vítima e quem era o perpetrador. "A última expressão no rosto de um homem assassinado, o choque quando vê um corpo mutilado: essas são imagens que os agentes carregam com eles”133.

O que, no início, era assustador, passa a ser rotina e as pessoas aceitam como um elemento que compõe seu trabalho. Por um lado, passam a naturalizar com mais facilidade as violências cometidas por parte de um preso contra outro. Mas eles demoram bastante para naturalizar o seu papel neste cenário de sofrimento. KAUFFMAN afirma que os agentes

\footnotetext{
132 Tradução livre da autora. Do original: “This is a prison and it is not society. When you step in here you step into a different world”. Idem, p. 229.

${ }^{133}$ Tradução livre da autora. Do original: "The lasting imprint of a murdered man's face, the shock at the sight of a mutilated body: these were images officers carried with them”. Idem, p. 223.
} 
precisam colocar na cabeça que os ASPs são seres humanos, bons seres humanos, ao passo que os presos são ou animais ou seres humanos maus.

De acordo com um entrevistado, a única forma de lidar com o medo é bater em alguém. Deste modo, se sente valorizado e mais forte ao criar a cultura de que os guardas são melhores do que os presos ${ }^{134}$.

Alguns agentes evitam usar violência dentro da prisão, mas acabam usando fora dela. Pessoas que nunca brigaram antes passam a ser protagonistas frequentes de brigas de bar. Ademais, efeitos nos relacionamento sociais também foram relatados. Ao aprender a agir segundo as regas da prisão, desaprendiam a seguir as regras do mundo exterior.

Um ASP contou que precisava se esforçar para não agir em casa como agia na prisão. O senso de que apenas aqueles que conhecem o mundo dentro dos muros podem compreender o que lá ocorre, faz com que os ASPs acabem se afastando mais e mais de suas famílias e amigos próximos. Muitos sentem que perdem a capacidade de se socializar e que não têm assuntos a tratar com pessoas que não conhecem de perto seu trabalho, acabam utilizando apenas gírias e metáforas que se aplicam ao mundo prisional.

Pelos motivos expostos, a rotatividade entre os ASPs é muito grande e são poucos os que suportam o trabalho por muito tempo. Porém, após deixarem o trabalho - o que exige grande coragem -, dificilmente conseguem outro emprego devido ao estereótipo criado em torno dos agentes penitenciários.

KAUFFMAN criou também uma tipologia de agentes penitenciários. Essa tipologia é formada por cinco categorias - os "Polianas", os "Esgotados”, os “Durões”, os "Vira Casaca” e os “Ambivalentes” - que demonstram o grau de identificação com o grupo de agentes e com o grupo de presos ${ }^{135}$.

Os “Polianas”136 e os "Esgotados"137 seriam os dois extremos. Os "Polianas" seriam aqueles ASPs que têm atitudes positivas para com os agentes e para com os presos, já os “Esgotados” apresentam atitudes negativas com relação aos dois grupos.

\footnotetext{
${ }^{134}$ Idem, p. 231.

${ }^{135}$ Idem, p. 244-263.

136 Tradução livre da autora. Do original: “Pollyannas”. Idem, p. 249.

137 Tradução livre da autora. Do original: “Burnouts”. Ibidem.
} 
Os “Durões”"138 são aqueles que apresentam condutadas positivas com relação ao grupo de agentes e atitudes negativas com relação ao grupo de presos. Os “Vira Casaca”"139 teriam atitude negativa para com os agentes e atitude positiva para com os presos.

Por fim, tem-se a categoria dos “Ambivalentes”140, que adotam posturas ambivalentes com relação aos dois grupos.

Em geral, o que a pesquisadora observou é que os agentes penitenciários ingressam na carreira apresentando atitudes positivas com relação aos presos e aos demais agentes e, com o passar do tempo, passam por mudanças e adotam posturas negativas primeiramente contra os presos e em seguida contra os agentes - e esse processo culmina com a exaustão física e psicológica. Claro que existem variações nesse padrão, mas ela pôde extrair essa regra geral.

\begin{abstract}
Poucos homens nesse estudo começaram a carreira como "Polianas", ou "Vira Casaca", ou como "Durões" (ou, menos frequente, como "Ambivalentes" ou "Esgotados"), e mantiveram sua orientação inicial pela duração de sua carreira na prisão. Mais comumente, os agentes desse estudo começaram como "Polianas", "Vira Casaca" ou "Durões" (aproximadamente nessa ordem de frequência), se tornaram "Esgotados" (alguns "Polianas" e "Vira Casacas" se tornaram "Durões" no caminho para se tornar "Esgotados"), após o que eles adotaram a postura de "Ambivalentes" ou se demitiram. ${ }^{141}$
\end{abstract}

Para concluir sua obra, KELSEY KAUFFMAN afirma que os problemas de interação que se apresentam nas prisões não têm suas raízes nas identidades e nas características dos agentes penitenciários e nem dos presos. Segundo ela, o problema é muito mais profundo e reside na base da Instituição Prisão. Eles estão inseridos nas raízes dos objetivos da prisão.

Muito mais importante do que o fracasso no ideal reabilitador dos presos, é o acentuado sucesso em desabilitar praticamente todos os que estão dentro daqueles muros. Segundo ela, o sistema prisional acaba por gerar um estímulo para o cometimento de crimes pelos funcionários do Estado dentro das prisões. Neste sentido, a responsabilidade

\footnotetext{
138 Tradução livre da autora. Do original: “Hard Asses”. Ibidem.

139 Tradução livre da autora. Do original: "White Hats”. Ibidem.

140 Tradução livre da autora. Do original: "Functionaries”. Ibidem.

141 Tradução livre da autora. Do original: "A few men in this study came into prison work as a Pollyanna, or a White Hat, or a Hard Ass (or, less frequently, as a Functionary or Burnout), and retained their initial orientation for the duration of their prison carreer. More commonly, officers in this study started out as Pollyannas, White Hats, or Hard Asses (in approximately that order of frequency), became Burnouts (some Pollyannas and White Hats became Hard Asses along the way to becoming Burnouts), following which they either settled into the role of Functionary or resigned”. Idem, p. 260.
} 
da sociedade e do Estado nesse processo é substancial e é necessário que se reconheça isso $^{142}$.

\subsection{Antoinette Chauvenet, Françoise Orlic e Georges Benguigui - Le}

\section{Monde des Surveillants de Prison ${ }^{143}$}

A pesquisa desses autores abordou muitos aspectos sobre o mundo do trabalho dos agentes de segurança penitenciária, sob uma perspectiva da Sociologia do Trabalho.

Para a realização desse estudo, ChAUVEnEt, ORLiC e BENGUIGUI realizaram 1.300 horas de observação em cinco unidades prisionais distintas na França ${ }^{144}$, entrevistaram mais de 300 pessoas (sendo 269 agentes penitenciários), por aproximadamente 3h30min cada um, e analisaram documentos oficiais da Administração Penitenciária ${ }^{145}$.

De acordo com os autores, no período pós $2^{\mathrm{a}}$ Guerra Mundial, na França, teve início um movimento por reformas no sistema prisional, mas ele continuou sendo a instituição total apresentada por GofFMAN, apesar de ter sofrido algumas alterações. O aumento nos direitos dos presos e o ingresso de profissionais técnicos no sistema - como os professores, assistentes sociais, psiquiatras - fez com que fosse aumentada a burocracia.

As leis e os regulamentos aumentaram em quantidade para regular os novos direitos e garantir o cumprimento destes. Tal burocratização e aumento de regras afetou substancialmente o trabalho dos agentes penitenciários. Contudo, as funções dicotômicas e paradoxais da prisão relevaram aos agentes penitenciários as funções de segurança e disciplina. Neste sentido, o aumento de atividades dos presos fez com que o foco do trabalho dos ASPs fosse movido pela ideologia da segurança.

Ademais, as contradições que se apresentam na função do agente não são resultantes apenas da dicotomia entre as funções opostas da prisão: de um lado, dissuasão, punição, defesa da sociedade, e de outro, reeducação, reabilitação, tratamento e reinserção ${ }^{146}$. São resultantes também da contradição existente nas novas regras e

\footnotetext{
142 Idem, p. 264-269.

${ }^{143}$ Chauvenet, Antoinette; OrLic, Françoises; Benguigui, Georges. Le monde des surveillantes de prison. Paris: Presses Universitaires de France, 1994.

${ }^{144}$ Idem, p. 210-212.

145 Idem, p. 209-212.

${ }^{146}$ De acordo com os pesquisadores, a reinserção é uma missão residual e utópica. Idem, capítulo 2.
} 
regulamentos e os meios que utilizavam para manter a ordem. As regras de segurança podem contradizer uma política de controle mais flexível da população carcerária e a obrigação de reportar de modo formal os atos de indisciplina dos presos contradiz as exigências da profissão de manutenção da ordem por via informal.

De acordo com os pesquisadores, a função do ASP está definida nos regulamentos como uma função meramente instrumental e de execução das normas. Mas a realização da função de agente penitenciário exige um grau de discricionariedade: as intervenções são decididas em razão da oportunidade e da circunstância específica de tempo e de lugar em cada caso. A manutenção da ordem não pode ser definida a priori. Ao passo que existem regras e procedimentos a ser seguidos, a forma com que controlam a população carcerária e são mantidas a segurança e a disciplina não são objeto de doutrinas ou teorias. A atuação cotidiana determina a forma de atuação dos $\operatorname{ASPs}^{147}$.

Para que possam conseguir a cooperação dos presos, evitar os incidentes e assegurar a ordem e a disciplina cotidiana é necessário que haja uma relação de respeito para com os presos, manutenção e cumprimento das promessas realizadas, a escuta e o diálogo.

Além disso, outra ferramenta importante no trabalho é a distribuição de tarefas para os presos. Esse é um aspecto fundamental identificado na pesquisa francesa. $O$ oferecimento de postos de trabalho para os presos pode ser utilizado como forma de recompensa ou para garantir a cooperação, mas também foi importante para reduzir a formação de coalizões entre os presos, já que os ASPs destacam para os postos de trabalho quem acham pertinente para a obtenção de seus objetivos.

Isso permite que se crie uma condição onde o ASP possa ter o controle da população carcerária e garantir a disciplina interna. Porém, tal atitude está em contradição com os regulamentos oficiais. Então, o ASP se vê em uma situação muito complicada e sem saber qual caminho seguir: se por um lado ele cumpre todas as regras, ele gerará uma situação de tensão em que não conseguirá manter a disciplina da unidade, mas, por outro lado, se não cumprir todas as regras e acontecer algum incidente, ele será responsabilizado por não ter seguido o regulamento à risca.

Ademais, a regra informal de reciprocidade que rege as relações pessoais entre presos e agentes é mantida em sigilo e confiança. Essa regra é fundamental para se garantir

\footnotetext{
${ }^{147}$ Idem, capítulo 1.
} 
a ordem na unidade, mas apesar de ser muito útil na perspectiva dos agentes - e dos presos - é uma atitude de risco.

A autoridade legítima dos ASPs é construída por meio de recursos ilegais, mas que são tolerados enquanto não geram qualquer desordem ou atitude indisciplinar. Essa ambiguidade está sempre presente no trabalho do agente penitenciário. Isso influencia diretamente a imagem que o ASP tem de seu próprio trabalho ${ }^{148}$.

Os pesquisadores puderam notar que há uma cisão entre o discurso que o agente tem sobre sua profissão, seu trabalho cotidiano, e sobre sua prática. O que também afeta a percepção que os presos têm dos agentes e da prisão em si.

O discurso público adotado pelos ASPs é um discurso ácido, contrário aos presos e à administração, ao passo que o discurso privado é organizado a partir da prática individual de cada agente que se fundamenta nas normas informais e principalmente na reciprocidade. Não há um espaço de troca entre os agentes e, assim sendo, eles não sabem o que seus colegas pensam ou como eles agem.

Há uma sensação de que estão sozinhos e realizando seu trabalho solitariamente, mas, ao mesmo tempo, a pesquisa identificou que a forma de trabalho adotada é muito similar, bem como os discursos empregados. Além de não terem um compartilhamento das dificuldades do dia a dia e a possibilidade de trocarem experiência com seus colegas, eles também acabam guardando para si o que fazem e, por esse motivo, não são avaliados e nunca ficam sabendo se estão realizando um bom ou mau trabalho.

Isso é um fator de angústia expressado por eles. Outro fator associado é o de que as satisfações que relataram sentir com relação à profissão, que são todas relativas aos fatores externos, como estabilidade e horários, mas não relacionadas ao conteúdo do desempenho profissional.

O fato da profissão de agente penitenciário ser rejeitada pela sociedade e até mesmo desprezada faz com que os agentes tenham que estar sempre "na posição defensiva”. Ademais, toda a força do discurso público - baseado na missão de segurança pública, ordem e disciplina, além de ter que incluir o fator reinserção social dos presos, aliada à

\footnotetext{
${ }^{148}$ As formas de controle da população carcerária, segundo os autores, passa pela fundamental tarefa de construção da autoridade. Eles identificaram como principais formas da obtenção de cooperação por parte dos presos: a conversa, a manutenção de um certo distanciamento entre ASP e preso, a descontração, as regras de etiqueta e de boa educação, o oferecimento de trabalho aos presos e os princípios profissionais construídos segundo a moral e a experiência dos agentes. Idem, p. 77-106.
} 
falta de segurança para o desempenho profissional e à falta de condições para o desenvolvimento de suas funções - é mais um fator de angústia que impacta diretamente o trabalho do ASP. As inseguranças vivenciadas pelos ASPs em seu cotidiano são de ordem moral, física, mental e psíquica.

De acordo com um dos entrevistados: “nós estamos em um jogo de fingimentos (...) nós estamos toda hora em um dualismo, em contradição (...) nós somos os atores e espectadores desse dualismo"149.

\title{
2.7. Luiz Antônio Bogo Chies - A Prisionalização do Agente Penitenciário:
}

\section{Um Estudo sobre Encarcerados sem Pena}

Obra de referência para o estudo mais detido sobre agentes penitenciários é a pesquisa, já citada acima, coordenada por LUIZ ANTÔNIO BOGO CHIES no âmbito do Grupo Interdisciplinar de Trabalho e Estudos Penitenciários da Universidade Católica de Pelotas - GITEP/UCPel, no período de julho de 1999 a julho de 2001, intitulada “O processo de prisionalização no exercício da função de agente penitenciário: um estudo no Presídio Regional de Pelotas”. ${ }^{150}$

Ao final do relatório da pesquisa há a afirmação de que:

\begin{abstract}
Cabe entretanto aqui, com o reforço da pesquisa realizada pelo GITEP, que se reivindique um espaço privilegiado dentro das pautas de interesse da(s) Ciência(s) Penitenciária(s) para a questão dos funcionários de presídios, vez que sensivelmente demonstrado pelos dados coletados os efeitos de afetação (e porque não perversos) que o Sistema Penitenciário dirige aos membros desse grupo social, em suas dinâmicas de inserção nas instituições totais penitenciárias. $^{151}$
\end{abstract}

\footnotetext{
149 Tradução livre da autora. Do original: “Ont est dans um jeu de faux-semblants. (...) On est toujours em dualisme, em contradiction. (...) On est des acteurs-spectateurs de ce dualisme.” Idem, p. 208.

${ }^{150}$ A pesquisa, que veio a ser publicada posteriormente, recebeu o título de "A prisionalização do agente penitenciário: um estudo sobre encarcerados sem pena”.

${ }^{151}$ CHIES, Luiz Antônio Bogo et al. Op. cit., p. 113.
} 
O GITEP realizou a pesquisa no Presídio Regional de Pelotas "Hamilton Cunha Gonçalves”152 e teve como objeto de estudo os agentes penitenciários. O objetivo da pesquisa era

\begin{abstract}
identificar e analisar o processo social de inserção e assimilação dos agentes penitenciários na estrutura institucional e organizacional carcerária, mais especificamente em termos de uma hipótese especial e característica forma de socialização daqueles por parte do ambiente e sistema oficial penitenciário. ${ }^{153}$
\end{abstract}

A pesquisa buscou, portanto, constatar, ou não, se esse grupo profissional sofre processo de prisionalização. Definiu-se esse conceito como um processo em que ocorre uma “especial socialização através da assimilação de hábitos, padrões de comportamento e valores sociais específicos do ambiente carcerário, eis que produzidos no sistema social que é gerado a partir das características organizacionais da instituição”154.

De acordo com o grupo que realizou a pesquisa, as respostas esteriotipantes e vindas do senso comum, que entendem que o agente penitenciário tem uma "maldade" intrínseca, que a função se constitui como mero exercício de poder com grande tendência à corrupção e, ainda, que este nutre um sentimento de inveja com relação aos presos, que receberiam melhor tratamento do que os próprios agentes, não foram consideradas como suficientes pelos pesquisadores para responder à questão formulada ${ }^{155}$, de modo a rejeitar “a superficialidade das respostas esteriotipantes que o senso comum, e mesmo a academia e a tradicional cultura jurídica, política e social, oferecem como verdades a priori”156.

Por considerarem que não se pode avançar na compreensão do estudo das questões penitenciárias sem que se atue no entendimento completo da complexidade de suas características, suas estruturas, seus processos e suas dinâmicas, é necessário voltar a atenção científica para os vínculos que os atores sociais possuem e estabelecem ${ }^{157}$, o que inclui, com relevância, o corpo de funcionários, em especial o agente penitenciário.

\footnotetext{
${ }^{152}$ Esta unidade era um presídio municipal até 1994, quando passou a ser uma unidade estadual. Em 1997 foi concluída a última reforma até a data da realização da pesquisa e a unidade passou a contar com 215 vagas. Importante destacar que esta unidade, apesar de ser destinada a presos do sexo masculino, também abrigava, na época da realização da pesquisa, presas do sexo feminino, constituindo não mais do que $5 \%$ do total de presos. A superlotação também era uma marca da unidade quando da realização da pesquisa. Idem, p. 37-38.

${ }_{153}^{15}$ Idem, p. 15.

154 Idem, p. 29.

155 Idem, p. 18.

156 Idem, p. 21.

157 Idem, p. 25.
} 
Nada se poderá conseguir num ambiente carcerário sem que se atue na compreensão total da complexidade de suas estruturas, processos e dinâmicas, enquanto elementos de um sistema social peculiar, do qual os funcionários do presídio compõem um grupo integrante que está a exigir a atenção de um olhar científico sobre os vínculos que seus membros possuem e estabelecem com tal sistema. $^{158}$

A pesquisa partiu da hipótese preliminar que vislumbrava a existência de um processo especial de socialização, especificamente o processo de prisionalização similar ao vivenciado pelo preso. Ou seja, a pesquisa teve como pressuposto a ocorrência da prisionalização do grupo de agentes penitenciários similar àquele vivenciado pelos reclusos.

O conceito utilizado na pesquisa é o “inicialmente nominado por Donald Clemmer de prisionalização, que se assemelha ao significado sociológico da assimilação e também ao de processo de socialização" ${ }^{159}$. Além deste conceito, as contribuições de Goffman, em especial aquelas sobre a instituição total, formam a base teórica da pesquisa. Para tanto, foram utilizados os fatores universais de prisionalização apresentados por Thompson, sendo que os enfoques dados foram: aceitação de um papel inferior; acumulação de fatores concernentes à organização da prisão; o desenvolvimento de novos hábitos para comer, se vestir, trabalhar, dormir; bem como a adoção do linguajar do local de trabalho ${ }^{160}$.

A metodologia adotada para a realização do estudo foi a aplicação de questionários aos agentes daquele presídio ${ }^{161}$. Inicialmente, o universo da pesquisa foi constituído por todos os agentes penitenciários que estavam lotados naquela unidade prisional, ou seja, trinta e três, porém, não foi possível realizar a pesquisa com três deles. Deste modo, o universo da pesquisa foi constituído por trinta agentes penitenciários que trabalharam naquela unidade durante o segundo semestre de $2000^{162}$.

O formulário aplicado era dividido em quatro blocos: o primeiro tinha a intenção de coletar dados gerais (idade, sexo, estado civil, escolaridade etc.); o segundo se destinou a buscar elementos para a discussão do papel social do agente penitenciário, focando na

\footnotetext{
${ }^{158}$ Ibidem.

${ }^{159}$ Idem, p. 28.

${ }^{160}$ Idem, p. 92.

${ }^{161}$ Foi desenvolvida uma pesquisa empírica, a partir do método indutivo, utilizando um formulário que teve como prioridade questões fechadas e escaladas. Idem, p. 36.

${ }^{162}$ Idem, p. 37-39.
} 
autopercepção acerca da expectativa social e acerca da expectativa de valorização do agente penitenciário; o terceiro destinou-se a verificar se ocorreu a alteração de hábitos e comportamentos após o ingresso na carreira; e o quarto bloco buscou aferir a intensidade da absorção que o ambiente penitenciário produz em relação ao agente penitenciário ${ }^{163}$.

O relatório final do estudo elaborado pelo GITEP trouxe diversos elementos interessantes para uma discussão aprofundada do tema e da problemática, porém, foi optado por apresentar aqui apenas alguns elementos que podem embasar diretamente a pesquisa que ora se apresenta.

Para tal, é importante a compreensão dos dados apresentados na Tabela 16 do relatório de pesquisa coordenada por CHIES, cuja pergunta era sobre o "grau de valorização que recebe o Agente Penitenciário: dos Juízes”, ou seja, cabia ao pesquisado responder como ele próprio percebe o grau de valorização que recebe dos juízes. Sendo assim, 10\% respondeu que "valoriza muito”; 26,67\% responderam que “valoriza”; 50\% responderam que “não valoriza, nem desvaloriza”; 13,33\% responderam que “desvaloriza”; e 0\% respondeu que "desvaloriza muito" 164 .

Logo na pergunta seguinte, os pesquisados eram convidados a emitir sua própria opinião sobre o objetivo da pena de prisão e 46,67\% apontaram a recuperação do preso como sendo o principal objetivo. Apenas o menor porcentual respondeu que a finalidade da pena de prisão seria o castigo ${ }^{165}$.

Em seguida, os pesquisados foram indagados sobre a sua própria atuação. Com relação a este aspecto, 56,67\% responderam que suas atividades se dirigem prioritariamente à manutenção da disciplina e da segurança. Os demais 43,33\% disseram que suas atividades se dirigem à recuperação do preso ${ }^{166}$.

$\mathrm{Na}$ questão seguinte, $70 \%$ do universo pesquisado apontou que sua atividade contribui pouco, ou muito pouco, para que o sistema penitenciário alcance seu objetivo prioritário. O que demonstra que os ASPs se percebem como profissionais com pouco valor para a instituição da qual fazem parte ${ }^{167}$.

\footnotetext{
${ }^{163}$ Idem, p. 39-41.

${ }^{164}$ Idem, p. 56-57.

165 Ibidem.

${ }^{166}$ Idem, p. 58-59.

${ }^{167}$ Ibidem.
} 
Pode-se, pois, já a partir destes dados cogitar-se da demonstração de uma afetação, em sentido negativo, na autoestima profissional dos agentes penitenciários enquanto inseridos na estrutura e dinâmicas da organização penitenciária, vez que relativa seria sua contribuição aos objetivos maiores da organização.

Nesse sentido não raras vezes os Agentes Penitenciários são comparados a meros 'cães de guarda', como se tal grosseira metáfora lhes fosse imputado tão somente a tarefa de contenção física e disciplinar do apenado. ${ }^{168}$

No que diz respeito ao grau de valorização, na percepção dos pesquisados, que os agentes penitenciários recebem de diversos grupos, notou-se que nenhum grupo superou o percentual de $50 \%$ de valorização. Somando as resposta para os itens "valoriza” e "valoriza muito”, obteve-se a seguinte escala no grau de valorização indicado pelos pesquisados: Promotores de Justiça, advogados e agentes penitenciários (cada um dos três grupos com 50\%); presos (40\%); juízes e equipes técnicas (ambos com 36,67\%); sociedade (26,67\%, sendo que neste item não houve nenhuma resposta que indicasse que a sociedade valoriza muito o ASP); SUSEPE $(16,66 \%)^{169}$.

A análise apresentada no relatório final da pesquisa é interessante e pode constituirse em importante fonte para a pesquisa que se pretende desenvolver. De acordo com os pesquisadores do GITEP, os agentes penitenciários se sentem mais valorizados pelos grupos que mais dependem deles, como é o caso da Administração Penitenciária, dos Promotores de Justiça, dos advogados e dos próprios presos ${ }^{170}$.

Sobre a SUSEPE, deve-se acrescentar que é o órgão "patronal” com o qual os ASPs entram em conflito no que diz respeito às reivindicações salariais e relativas às condições de trabalho ${ }^{171}$.

Por outro lado, o agente penitenciário se sente menos valorizado quanto mais distante do ambiente prisional está o grupo, como é o caso dos juízes, que, na estrutura do Poder Judiciário, estão mais distantes do que os Promotores de Justiça ${ }^{172}$.

Como o estudo que se pretende realizar neste trabalho está permeado pela relação entre os agentes penitenciários e o Poder Judiciário, serão reproduzidos os dados apresentados na Tabela 16 do Relatório de Pesquisa coordenada por Chies, cuja pergunta foi sobre o "grau de valorização que recebe o agente penitenciário: dos juízes”, ou seja,

\footnotetext{
${ }^{168}$ Idem, p. 59.

${ }^{169}$ Idem, p. 60-66.

${ }^{170}$ Idem, p. 64.

${ }^{171}$ Ibidem.

172 Ibidem.
} 
cabia ao pesquisado responder como ele próprio percebe o grau de valorização que recebe dos juízes. 10\% responderam que "valoriza muito"; 26,67\% responderam que "valoriza”; $50 \%$ responderam que "não valoriza, nem desvaloriza”; 13,33\% responderam que “desvaloriza”; e $0 \%$ responderam que “desvaloriza muito"173.

Ao final da pesquisa foi constatada “a existência de um 'processo especial de socialização’, similar àquele denominado de prisionalização, ao qual são submetidos os agentes penitenciários” ${ }^{\text {"174 }}$, em decorrência do seu ambiente de trabalho.

De acordo com a pesquisa apresentada pelo GITEP,

\begin{abstract}
nas instituições totais "os processos especiais de socialização” se tendem (sic) a apresentar como dessocializadores dos padrões de socialização exteriores à instituição. E, no caso das instituições penitenciárias, que este "processo especial de socialização”, a prisionalização, resulta em nociva dessocialização, vez que pautado e balizado pela negação de valores sociais superiores, como a liberdade, no conflito irresolvível dos objetivos organizacionais, e no antagonismo das dinâmicas possíveis e dos conteúdos dos papéis atribuídos aos seus participantes. $^{175}$
\end{abstract}

\title{
2.8. Pedro Rodolfo Bodê De Moraes - Punição, Encarceramento e
}

\section{Construção da Identidade Profissional entre Agentes Penitenciários}

Uma obra particularmente importante para a compreensão do sistema carcerário sob a ótica do agente penitenciário é o livro, resultado de pesquisa de doutorado, de PEDRO Rodolfo BodÊ DE Moraes, intitulado "Punição, Encarceramento e Construção da Identidade Profissional entre Agentes Penitenciários”176.

O autor dedicou-se a realizar entrevistas com agentes penitenciários, no Estado do Paraná, tendo como questão principal a percepção do universo prisional do ponto de vista dos próprios agentes. O fio condutor do livro é a noção de que o trabalho é indutor de identidade profissional, social e cultural. A partir disto, o autor propõe-se a discutir quais são os efeitos das instituições prisionais nessa construção de identidades ${ }^{177}$.

\footnotetext{
${ }^{173}$ Idem, p. 61.

${ }^{174}$ Idem. p. 108.

175 Idem, p. 111.

${ }^{176}$ Ibidem.

${ }^{177}$ Idem, p. 33.
} 
Contudo, o autor relata dificuldades metodológicas, entre elas o fato da sociedade ter uma imagem formada sobre esse grupo profissional, extremamente negativa, o que, de certo modo, dificulta o trabalho do pesquisador, já que há uma grande carga de preconceito incutida. Em suas palavras, esse elemento fica evidenciado: “Os agentes penitenciários um grupo pouco conhecido cientificamente, mas absolutamente antipatizado e visto como composto por indivíduos 'maus', 'torturadores', ‘corruptos', enfim, piores do que aqueles que eles guardam e vigiam”, 178 .

Ele continua descrevendo suas dificuldades metodológicas e esbarra na escassez de material bibliográfico sobre o assunto. “Ao procurarmos material sobre os agentes penitenciários (...) observamos que era muito pequena a produção de pesquisas, trabalhos e reflexões sobre o sistema penitenciário, no caso dos agentes penitenciários, ela é quase inexistente" 179 .

BodÊ DE MorAes acrescenta, ainda, que, na maioria das vezes, esse grupo, quando citado nos trabalhos sobre as prisões, aparece de maneira estereotipada, como corrupto e violento $^{180}$.

Para a compreensão deste grupo, seria preciso entender que ele é composto, em geral, por pessoas oriundas da mesma classe social que os presos. A questão de fundo aqui é que a prisão tem como clientes preferenciais os pobres, o que reforça o estigma sobre essa classe social, fazendo com que seja prova inconteste da periculosidade dos pobres. A prisão, além disso, confirma a periculosidade das classes pobres para os próprios pobres, que veem seu grupo social representado na população carcerária ${ }^{181}$.

O autor extrai, das entrevistas que realiza com ASPs, elementos fundamentais para a compreensão do universo dos agentes penitenciários e das complexas tramas que se desenvolvem na prisão.

BoDÊ destaca que, por serem os ASPs e os presos oriundos da mesma classe social, os ASPs veem a prisão como "parte possível do seu destino"182.

\footnotetext{
${ }^{178}$ Idem, p. 43.

${ }^{179}$ Idem, p. 74.

180 “os responsáveis pela guarda e vigilância de presos, que possuem várias denominações diferentes, aparecem apenas de forma secundária nos trabalhos sobre a prisão e o sistema penitenciário, no entanto, a forma que aparecem é sempre a mesma, destacando-se entre as suas características a corrupção e a violência.” Idem, p. 160.

${ }^{181}$ Idem, p. 93.

${ }^{182}$ Idem, p. 94.
} 
No que diz respeito à violência física, BoDÊ identificou que parte desta empregada pelos ASPs contra os presos é uma tentativa de "quebrar o espelho", de reforçar as diferenças entre os dois grupos, como se os ASPs estivessem demarcando que a identidade de trabalhador está distante da identidade de preso, vagabundo e bandido ${ }^{183}$.

O autor chama atenção para a construção da identidade de trabalhador e da importância que isso tem na formação social dos ASP. Com o ingresso no sistema penitenciário, no papel de agente da lei, o indivíduo forma ou reforça sua identidade de trabalhador, que se distancia da identidade dos bandidos e vagabundos ${ }^{184}$.

Sobre tal ponto, a pesquisa da CASTRO E SILVA, que será explorada mais adiante, aborda a questão de um modo distinto, enunciando os conceitos de “código da cela”; de “ser sujeito homem” e da "violência negociada”.

Neste aspecto, podemos incluir o que o autor colocará mais para frente em seu livro, que o ASP, logo no primeiro dia de trabalho, se distancia do papel que desempenhava como civil, passando a ser um agente penitenciário. A transformação de civil para ASP é acompanhada de um ritual de passagem. Em geral, os novatos são colocados para desempenhar alguma atividade que exigiria mais experiência logo no seu primeiro dia de trabalho, como uma forma de batismo na nova profissão. Muitos relataram ao autor que nunca esquecerão tal evento, fazendo referência à situação chocante que vivenciaram $^{185}$.

\footnotetext{
Assim, o primeiro dia torna-se para o agente penitenciário que está entrando, iniciando seu trabalho, uma fronteira que delimita a vida do cidadão comum e a de agente penitenciário. Essa delimitação, por sua vez, é marcada por um duro ritual por parte dos agentes penitenciários mais velhos que permitem que estes “já tenham uma idéia (sic) de como o cara é. ${ }^{186}$
}

Outro elemento destacado é a impossibilidade dos ASPs e presos se “misturarem”. Isso porque "as fronteiras entre presos e agentes penitenciários são frágeis ou movediças” ${ }^{187}$. É necessário que o ASP aprenda muito rapidamente a dinâmica da prisão: ele precisa entender como pensa o preso para poder garantir a ordem e a disciplina.

\footnotetext{
183 Ibidem.

${ }^{184}$ Idem, p. 95.

185 Idem, p. 234-237.

186 Idem, p. 237.

${ }^{187}$ Idem, p. 96.
} 
Contudo, o aprendizado tem um custo alto com relação à identidade do agente, o que gera também grandes conflitos psíquicos, "uma vez que significa para o agente penitenciário mimetizar-se naquilo que ele percebe como a sua antítese”" ${ }^{188}$, sendo que "o perigo deste tipo de relação é o de sempre: a 'aproximação excessiva', a 'identificação com o preso' e o ‘contágio moral’”,189.

Assim, o agente está em uma posição ambígua, em que há uma cisão entre o mundo da lei e da ordem e o mundo do crime e da desordem. Contudo, tal posição conflitante e ambígua gera um estresse contínuo. Tanto que, como tentativa de garantir sua higidez psíquica, é necessário que o ASP passe a naturalizar, a internalizar e a se familiarizar com essas situações $^{190}$.

Algumas vezes, essa mistura pode levar o ASP a desempenhar o papel do bandido, não mais de trabalhador. Por vezes, este “passar para o outro lado” é visto pelos ASPs como uma tentação, inclusive por, comumente, acharem que os presos são mais bem tratados do que eles pelo sistema prisional, fazendo com que se sintam diminuídos e preteridos $^{191}$. Neste ponto, o autor coloca que o ASP está utilizando um argumento que tem sua carga de verdade, de que “ele também é passível de ser 'vítima' da sociedade e constitutivo da profecia auto-cumprida, que já atingiu os presos que ele vigia e pune”192.

Além disso, os agentes acabam assimilando comportamentos típicos da cadeia e levando-os consigo para a vida fora dela. Isso é algo que, quando se dão conta, os incomoda $^{193}$.

Neste contexto está, segundo o autor, o fato dos ASPs também denunciarem as injustiças da prisão, se compadecendo dos presos. Neste ponto, o autor identificou que os ASPs têm a compreensão de que existe um grupo típico e vulnerável que é selecionado pela prisão e integrar esse grupo é mais importante do que o fato de ter cometido algum crime na determinação de quem será e quem não será preso. Assim, BoDÊ esclarece que os ASPs deixaram claro em diversas entrevistas que existem muitos inocentes e laranjas presos, ao passo que muito criminosos estão "viajando por aí”"194. Ou seja, as injustiças da

\footnotetext{
188 Idem, p. 221.

189 Idem, p. 251.

190 Idem, p. 222.

191 Idem, p. 248.

192 Idem, p. 96.

193 Idem, p. 231.

${ }^{194}$ Idem, p. 96.
} 
prisão e a forma de recrutamento dos presos e dos profissionais responsáveis pela guarda e vigilância estão diretamente vinculadas à classe social.

As questões sobre a saúde mental dos agentes penitenciários são extremamente sérias. O ASP aprende que deve ficar o tempo todo atento e vigilante, além de ter que identificar em quem pode, ou não, confiar. Então, passa a identificar os sinais de que algo está por vir. Quando a cadeia, por exemplo, está muito silenciosa, quieta, é porque, de acordo com falas coletadas pelo pesquisador, os presos estão "armando alguma coisa". Neste sentido, “o silêncio e as calmarias tornam-se um verdadeiro tormento"195.

Nas entrevistas realizadas, BoDÊ pôde constatar que os ASPs costumam falar das doenças físicas e também das psíquicas que os seus colegas tiverem em decorrência do trabalho na prisão, ou de um modo coletivo, porém, têm muita dificuldade em falar dos seus próprios desequilíbrios, já que tal forma de sofrimento é associada à fraqueza e fragilidade $^{196}$. E os ASPs precisam a todo tempo se distanciar destas imagens para conseguir manter sua autoridade.

Um outro ponto colocado em relevo pela pesquisa é a associação entre contágio moral, imobilidade e a distribuição e organização dos espaços dentro da cadeia ${ }^{197}$.

Neste sentido, quanto mais portões se adentre na cadeia, mais se está próximo dos piores presos e, também, mais imobilizado se fica. As solitárias, celas de castigo, não por coincidência, ficam no chamado fundão, no ponto mais distante do portão de entrada. Ficou claro para o pesquisador que

\footnotetext{
o fundo diz respeito a uma dicotomia moral-imoral-amoral; ali estariam os piores presos, os mais moralmente questionáveis. Assim o que observamos é que quanto mais criminoso, mais no fundo, quanto mais imoral ou amoral, mais imóvel. Por isso é que quanto mais dentro da cadeia, maior a possibilidade de contágio moral do agente penitenciário porque em contato com esse tipo de preso. $^{198}$
}

\footnotetext{
195 Idem, p. 225.

196 Idem, p. 229.

${ }^{197}$ Idem, p. 243-245.

198 Idem, p. 245.
} 
2.9 Anderson Moraes de Castro e Silva - Nos Braços da Lei: o Uso da Violência Negociada no Interior das Prisões

Outra pesquisa muito interessante realizada sobre o assunto foi a de ANDERSON Moraes de Castro e Silva, intitulada Nos Braços da Lei: O Uso da Violência Negociada no Interior das Prisões. Esta obra, publicada em livro, foi sua dissertação de mestrado, defendida em 2006, na UFRJ.

O autor foi agente penitenciário e, depois disso, policial civil no Estado do Rio de Janeiro. Quando realizou sua pesquisa não mais exercia nenhuma das duas funções, porém, certamente sua biografia influenciou seu estudo.

Versou sobre os códigos não escritos, informais - extralegais como o autor coloca que estão presentes na relação entre preso e ASP. Ele demonstrou que a estabilidade da prisão, mesmo que com uma estabilidade frágil, só é mantida por conta dos acordos, acertos e negociações entre os personagens envolvidos. Em diversos casos, tais negociações não estão de acordo com a Lei de Execução Penal, porém, de acordo com o código extralegal que vigora nas Penitenciárias.

A pesquisa teve como foco a ótica do agente penitenciário e "foi pensada no sentido de pluralizar as interpretações existentes sobre o cotidiano do sistema penal fluminense" ${ }^{199}$. O objetivo do autor era buscar as autoexplicações que os agentes penitenciários dão para o uso da força física dentro das unidades penitenciárias, a partir da escuta de suas falas.

Ele destaca a força do eixo vigilância-segurança na condução da administração prisional e das ações institucionais na prisão ${ }^{200}$.

CASTRO E SiLva pôde identificar três categorias de violência física aplicada pelo ASP contra o preso: violência legal, extraoficial e negociada.

A violência legal é aquela prevista em lei e nos códigos de conduta oficiais e escritos. Ou seja, quando todas as outras alternativas já tiverem se esgotado, a força física

\footnotetext{
${ }^{199}$ CASTRO E Silva, Anderson Moraes de. Op. cit., p. 1.

${ }^{200}$ Idem, p. 9.
} 
pode ser usada em determinadas situações, como em caso de legítima defesa, em caso de tentativa de fuga e/ou para a manutenção da segurança e da ordem dentro da unidade ${ }^{201}$.

A violência extraoficial é aquela que tem a intenção de ser corretiva e disciplinadora $^{202}$. Já a violência negociada é antecedida por uma conversa entre as partes e resulta de um acordo entre elas. Ou seja, a aplicação da violência negociada está legitimada pela ética local, o que dá a entender que há um consenso sobre as situações em que se deve usar a violência física como forma de castigo legítimo. Porém, do ponto de vista jurídico, ela é tão extraoficial, portanto tão criminosa, quanto a que o autor denominou de violência “extraoficial”.

Para compreender a violência física negociada é necessário entender dois outros conceitos trazidos pelo autor: código da cela e ser sujeito homem.

O código da cela é composto pelas regras marginais - que estão à margem da lei - e que regem a vida dentro das unidades prisionais. De acordo com o autor, os presos passam pelo processo de mortificação do eu - conceito de GOFFMAN - e, paralelamente, são socializados na ética da cadeia, ou seja, apreendem o código da cela: esse código que orientará sua vida dentro da prisão.

Para além da socialização dos presos no código da cela, o autor acrescenta que os próprios ASPs também passam por esse processo de socialização que inclui o aprendizado do código da cela. Isso porque, ao se tornar agente penitenciário, é necessário que o indivíduo deixe de ser “civil”. "Desta forma, tanto guardas quanto internos são socializados a partir dos valores vigentes no interior das prisões, no 'código da cela', 203 .

O código da cela inclui desde questões simples como regras de etiqueta - usar camisa, fazer a barba etc. - quanto regras de resolução de conflitos.

Sendo assim, tanto os presos quanto os agentes adquirem uma nova identidade e passam a ser regidos por um novo conjunto de regras. Para o autor, integrando essa nova identidade está a noção de ser sujeito homem. Ser sujeito homem inclui aspectos associados à masculinidade - virilidade, coragem e honra, por exemplo - e também ao poder - autoridade, hierarquia, disciplina etc.

\footnotetext{
${ }^{201}$ Idem, p. 114-117.

${ }^{202}$ Idem, p. 117-120.

${ }^{203}$ Idem, p. 107.
} 
Dentre as características presentes no fato de ser sujeito homem está a utilização do uso da força física como forma de solução dos conflitos.

\begin{abstract}
Como a violência negociada era "parada de homem”, essas agressões físicas jamais chegavam ao conhecimento das autoridades competentes, portanto, essas condutas não eram criminalizadas nem os guardas incriminados. Os guardas diziam que o preso assumia o risco de ser castigado desta forma no momento em que decidia cometer uma ação cuja punição prevista, na ética da cadeia, era o castigo físico. Desta forma, se fosse pego, o interno deveria "ser sujeito homem! E arcar com as conseqüências (sic) de sua conduta. ${ }^{204}$
\end{abstract}

Ser sujeito homem é algo muito forte, de acordo com a pesquisa de CASTRO E SILVA, e isso passa a ser uma forma de diferenciação entre os agentes penitenciários e os demais civis: o fato de que os ASPs são mais homens do que os demais ${ }^{205}$.

Sugiro aqui que não é apenas a socialização do agente penitenciário no "mundo do crime" o elemento que o faz legitimar o uso da força física em substituição à punição formal, mas também o próprio self que lhe fora “esculpido” após a iniciação profissional como operador da lei. Acredito que a noção do "ser sujeito homem”, comum a ambos os grupos, seja um dos fatores que possibilita a identificação e o compartilhamento do uso da força física na resolução de conflitos intra e intergrupos. ${ }^{206}$

Para o preso, muitas vezes, o castigo físico era a forma mais branda de punição que poderia receber naquele momento. De acordo com CASTRO E SILVA, não há a presença de um elemento de prazer pela própria dor, mas sim uma busca pela sobrevivência. Os trâmites formais de punição lhe acarretariam um prejuízo maior, pois aumentariam seu tempo de pena. Além disso, a punição física, por vezes, poderia livrar o preso de ser castigado pelo próprio coletivo de presos.

Existem duas regras para que a violência física decorrente da categoria de violência negociada seja válida: não se pode bater no rosto e também a agressão deve usar a mão fechada, “pois quem apanha de mão aberta é 'mulher”,207. Sendo assim, apenas ocorreria insulto moral se essas duas regras fossem desrespeitadas.

\footnotetext{
${ }^{204}$ Idem, p. 120.

205 Idem, p. 109.

${ }^{206}$ Idem, p. 107.

${ }^{207}$ Idem, p. 127.
} 
Após a aplicação do castigo físico, o conflito estava resolvido e não se dava andamento à situação. Na pesquisa, ficou claro que nenhum dos dois grupos tinha interesse em seguir o procedimento legal para solucionar os impasses.

Por um lado, para o preso, o uso da violência física negociada não prejudicaria o andamento do cumprimento da sua pena. Por outro lado, "além de livrar o agente estatal das malhas da burocracia e de possíveis constrangimentos nas instituições de ordem, permitiria que os acontecimentos do cárcere não interferissem em suas atividades na segurança privada (o dito 'bico'),"208, já que os depoimentos perante a autoridade policial e judicial ocorrem, em geral, nos dias de folga, para não atrapalhar a rotina da penitenciária em que atua.

Ademais, o autor coloca que não é apenas o ser sujeito homem que explica a presença da violência física dentro das penitenciárias, mas acredita que somado a tal elemento estão outros fatores: a falta de investimento de recursos financeiros no sistema penitenciário e a força do eixo vigilância-segurança, em detrimento de qualquer outro ideal que o cumprimento da pena pudesse ter, faz com que as condições prisionais sejam precárias.

Dentre os elementos de precariedade encontramos a ausência de pessoal suficiente para realizar todas as funções necessárias. Por isso, é extremamente comum que presos realizem tarefas que competiriam à Administração Penitenciária, como as ligadas à limpeza, à cozinha e até mesmo às administrativas. O fato do trabalho do preso ser essencial para que a cadeia continue equilibrada, faz com que haja certa cumplicidade, em razão da dependência e da convivência, entre os atores.

Desta forma, não é conveniente para o ASP recorrer a procedimentos legais para a punição do preso. Isto é visto como extremamente prejudicial para o preso, trabalhoso e custoso para o próprio agente, sendo assim, o código de ética da cadeia, o código da cela, seria a melhor forma de resolver o problema. Como todos os envolvidos precisam mostrar serem sujeitos homens, a força física acaba sendo utilizada como forma de solução negociada do conflito.

Assim, as duas partes saem ganhando com a aplicação dos castigos físicos, na lógica da violência negociada.

${ }^{208}$ Idem, p. 136. 
Ao final, o autor conclui que

raramente estes profissionais [agentes penitenciários] recorrem a este recurso [trâmites legais], preferindo negociar com o interno uma solução local, baseada na violência física ou na corrupção. A sujeição do servidor prisional à burocracia do sistema de justiça criminal só teria sentido para ele nas ocasiões em que fosse a intenção do guarda "prejudicar” o interno. Nessa interpretação, a punição legal perde o seu caráter disciplinador e passa a ser utilizada como um mecanismo personalíssimo de "vingança" contra o apenado. Por outro lado, ao interno disciplinado restava o perdão ou a violência negociada. Existe ainda um grupo de servidores que pouco se importava com o que estava ocorrendo na cadeia, e esqueciam que, ao se omitirem, também agiam criminosamente. ${ }^{209}$

\subsection{Arlindo da Silva Lourenço - O Espaço de Vida do Agente de Segurança} Penitenciária no Cárcere: entre gaiolas, ratoeiras e aquários ${ }^{210}$

O autor dedicou sua tese de doutorado ao estudo do espaço de vida dos agentes penitenciários na perspectiva da teoria de Lewin. Segundo ele, o espaço de vida pode ser entendido como “a interdependência dinâmica entre pessoa e ambiente”211. Além do espaço do trabalho, há outros espaços importantes para a composição do espaço de vida de cada um, mas no trabalho as pessoas buscam a realização pessoal da coletividade e a satisfação das suas expectativas e necessidades. Por isso, o ambiente do trabalho é fundamental para a constituição do espaço de vida das pessoas ${ }^{212}$.

Ele era psicólogo de uma das duas unidades prisionais em que realizou suas observações participantes.

Nas prisões, de acordo com LOURENÇO, vivem dois grupos de pessoas que são obrigadas a conviver com ambientes escuros e úmidos, em espaço ínfimos e precários, a seguir ordens arbitrárias. Esses dois grupos

aprendem e se acostumam com a violência, com o isolamento e a distância social, assim como a barbárie, a opressão e a morte. Agentes de segurança

\footnotetext{
${ }^{209}$ Idem, p. 140.

${ }^{210}$ LOURENÇO, Arlindo da Silva. O espaço de vida do agente de segurança penitenciária no cárcere: entre gaiolas, ratoeiras e aquários. 2010. Tese (Doutorado em Psicologia) - Instituto de Psicologia, Universidade de São Paulo, São Paulo. 2010.

${ }^{211}$ Idem, p. 37.

${ }^{212}$ Ibidem.
} 
penitenciária e presos são esses dois grupos que mantêm entre si relações de sistemática e limítrofe intimidades e conflitos. ${ }^{213}$

O autor aponta para o fato de que é difícil construir qualquer projeto de vida pessoal, familiar ou profissional quando se sabe dos altos riscos que a sua profissão compreende ${ }^{214}$.

LOURENÇO dedica grande parte de sua obra para os impactos emocionais e psicológicos que o trabalho no cárcere produz na saúde dos ASPs.

2.11 ADRIANA REZENDE FARIA TAETS - Abrindo e Fechando Celas: narrativas, experiências $e$ identidades de agentes de segurança penitenciária femininas ${ }^{215}$

ADRIANA TAETS faz parte dos pesquisadores brasileiros que recentemente tem se dedicado a compreender com mais profundidade os agentes penitenciários. Dedicou sua pesquisa de mestrado à temática das agentes penitenciárias femininas e buscou compreender a forma como tais mulheres interpretam suas trajetórias e a maneira como se relacionam com o sistema prisional ${ }^{216}$.

A pesquisadora entrevistou agentes penitenciárias que trabalham no Estado de São Paulo. Acabou centrando sua dissertação na trajetória profissional de duas agentes, Solange e Léo ${ }^{217}$. A partir das narrativas destas agentes, a autora traça análises.

Ao final, afirma que “a instituição prisional informa as trajetórias profissionais das agentes penitenciários, ao mesmo tempo em que as escolhas pessoais de tais indivíduos modificam a instituição" ${ }^{218}$. A instituição faz um esforço para formatar a visão de mundo de seus funcionários de modo a estabelecer uma diferenciação entre os ASPs e os presos, o que acaba por justificar a pena de prisão.

Sobre o trabalho dos agentes penitenciários, TAETS destaca que o regime de turnos é visto como positivo por permitir um respiro em razão da atividade estressante desenvolvida dentro das unidades prisionais. As entrevistadas não associaram os turnos

\footnotetext{
213 Idem, p. 32.

${ }^{214}$ Idem, p. 50.

215 TAETS, Adriana Rezende Faria. Op. cit.

${ }^{216}$ Idem, p. 16.

${ }^{217}$ Nomes fictícios dado pela autora da pesquisa, ADRIANA REZENDE FARIA TAETS.

${ }^{218}$ TAETS, Adriana Rezende Faria. Op. cit., p. 28.
} 
com a possibilidade de realizar os afazeres domésticos e cuidar dos filhos e, para os homens, fazer "bicos" para aumentar a renda ${ }^{219}$.

A autora destaca o medo e a ansiedade como fatores presentes de modo intenso no trabalho das ASPs. A necessidade de estar sempre em estado de alerta e atenta a qualquer coisa que possa acontecer, são fatores geradores de muito estresse e cansaço. Além disso, o medo sempre presente também produz impactos negativos sobre o físico e o emocional das agentes.

Outro aspecto destacado pela autora é a falta de produtividade no serviço de agente penitenciário. Por não ser uma atividade produtiva e tampouco uma prestação de serviço, ao final do dia o profissional não consegue perceber o resultado do seu trabalho. Uma das agentes entrevistadas por ela afirmou que todos os dias são iguais na penitenciária: "Não existe segunda, terça, ou quarta, é sempre igual, e não importa a Penitenciária, é tudo igual, a rotina é sempre igual”220.

Ademais, segundo a pesquisadora, a separação entre o mundo intramuros e o extramuros não é evidente. Mas o problema não reside em levar o que se passa fora dos muros para dentro, mas exatamente o contrário. A família se queixa da maneira de se portar das agentes fora de serviço. É comum o relato de agressividade, de gritaria e da forma de falar ${ }^{221}$.

No que diz respeito à formação para ser ASP, a Escola de Administração Penitenciária fornece cursos demasiadamente teóricos e a crítica que recebem é que os agentes penitenciários vão aprender o que é a sua profissão apenas no exercício prático cotidiano. É destacado que seria interessante ter um curso baseado em “conselhos” sobre a prática $^{222}$.

Um dos aspectos bastante destacados é a dificuldade que as agentes sofrem para se diferenciar das presas, especialmente por serem da mesma origem social e terem adotado condutas similares ao longo de suas vidas, como o uso de drogas.

Apesar de percorrer trajetórias parecidas às das pessoas que foram presas, guardas e outros trabalhadores das instituições de controle encontram-se a salvo

\footnotetext{
${ }^{219}$ Idem, p. 61-62.

${ }^{220}$ Idem, p. 65.

${ }^{221}$ Idem, p. 65-68.

${ }^{222}$ Idem, p. 141-147.
} 
dos recursos punitivos, já que se dispõem a trabalhar em favor de tais instituições e, consequentemente, a favor da punição. ${ }^{223}$

Interessante o elemento apresentado por TAETS de que as agentes, além de controlarem as atividades propriamente ditas das presas, tentam, também, controlar seu imaginário e sensações. O exemplo apresentado é o controle das cartas amorosas que as presas recebem. Caso a carta descrevesse uma relação sexual considerada "indecente" pelas ASPs, as presas receberiam castigo na solitária. Esta é uma forma de expressão de poder intensa por parte das agentes, o que geraria um grande prazer. Esse é um dos motivos explicativos para que agentes prisionais - masculinos e femininos - se mantenham na profissão mesmo identificando esta como insalubre, tensa e perigosa ${ }^{224}$.

Tal prazer pode levar ao que Léo classificou como "síndrome do pequeno poder”, em que as agentes abusam do poder de disciplina ou do poder de atrapalhar o cumprimento de pena das presas e dificultar que passem a ter direito à progressão de regime e outros benefícios. Léo chama esse poder de "poder da caneta"225.

A visão que a ASP tem da sua profissão no presente é de que cabe a ela vigiar as presas e que a punição seja aplicada no momento presente. Não se pensa no futuro, em uma possível ressocialização. A profissão está voltada para o presente ${ }^{226}$.

Qualquer ação que pudesse ser interpretada como uma forma de proximidade entre as presas e as agentes era mal vista e a ASP correria o risco de ter suas condutas interpretadas como traição ou corrupção. Mesmo que essas condutas fossem apenas para cuidar da “dor das presas”, como está muito presente na história de Léo apresentada pela autora $^{227}$.

A pesquisadora coloca em sua dissertação que é impossível não adoecer estando dentro do sistema prisional. Agentes que agem de modo muito rígido e não se compadecem da dor do preso acabam sendo afetados psicologicamente e até fisicamente. E aqueles, como Léo, que se compadecem do sofrimento dos presos também adoecem ${ }^{228}$.

\footnotetext{
223 Idem, p. 103.

${ }^{224}$ Idem, p. 104-107.

225 Idem, p. 139.

${ }^{226}$ Idem, p. 108-109.

${ }^{227}$ Idem, p. 130-131.

${ }^{228}$ Idem, p. 140.
} 
TAETS esboça análises sobre o impacto da presença do PCC ${ }^{229}$. As entrevistas que realiza apontam para uma alteração profunda na dinâmica prisional e na função exercida pelos agentes penitenciários ${ }^{230}$. Antes da presença do PCC as agentes controlavam as unidades, mas essa dinâmica se alterou significativamente. Interessante destacar que o cotidiano passou a ser permeado por medo já que ameaças de que as famílias das agentes podem sofrer são constantes. Este medo se apresenta de modo mais intenso quando a agente está fora do presídio, pois é lá que sua família pode sofrer alguma represália e ela própria pode ser vítima de alguma emboscada.

Ao mesmo tempo em que o medo quando se está fora da unidade prisional aumenta, o medo quando se está dentro diminui. “A guarda justa não precisa temer. Quem teme é a guarda violenta e corrupta: aquelas que de alguma maneira abusam do poder, ou então, são consideradas, na visão do coletivo de presas, tão criminosas como as presas e por isso deveriam elas estar reclusas também.”231

TAETS destaca que a presença do PCC modifica o jogo de identidades, produzindo uma inversão no caráter espacial: a agente sente medo na rua e sente-se segura no presídio. “O PCC, de certa forma, prende os guardas no presídio, enquanto controla a dinâmica da cidade $^{232}$.

Antes do fortalecimento do PCC, as ASPs se sentiam diferentes das presas em vários sentidos, mas o principal motivo de diferenciação era de que as presas estavam do "lado de lá” das grades, possuindo um número de matrícula, enquanto as agentes estavam do "lado de cá". Mas, com a presença do PCC isso se altera, pois as presas passam a ter controle do que acontece fora da prisão.

Outro fator que modifica o jogo de identidades é que as ASPs deveriam ser responsáveis por assegurar a ordem e a disciplina, mas com a presença do PCC são as lideranças da facção que se tornam responsáveis por isso. Não se tendo mais a possibilidade de manter relações de proximidade com as presas - tanto porque as ASPs podem ser acusadas de corrupção, quanto porque as presas podem ser acusadas de estar se

\footnotetext{
${ }^{229}$ PCC é sigla utilizada para se referir ao Primeiro Comando da Capital, facção criminosa mais numerosa do Estado de São Paulo. Vide infra categoria 10, capítulo 5, item 5.10.1.

${ }^{230}$ TAETS, Adriana Rezende Faria. Op. cit., p. 109-111; 153-157; 170-173.

${ }^{231}$ Idem, p. 110.

232 Ibidem.
} 
associando à polícia ${ }^{233}$ - “o que resta é abrir e fechar grades”"234, ou seja, a facção retirou o poder dos agentes.

\subsection{Raphael Sabaini - Uma Cidade entre Presídios: Ser Agente Penitenciário}

em Itirapina - SP 235

Raphael Sabaini se dedicou ao estudo das dinâmicas que se desenvolvem em uma pequena cidade do interior paulista em razão da existência de duas penitenciárias ${ }^{236}$. Itirapina tem 15 mil habitantes e o cotidiano e as relações que se estabelecem na cidade são muito marcados pela presença das unidades prisionais. A construção da segunda unidade prisional se deu no contexto de implantação da política de interiorização das prisões. ${ }^{237}$

A pesquisa de Sabaini vem complementar o conhecimento sobre os agentes penitenciários, ao analisar uma cidade de interior fortemente marcada pela presença das unidades prisionais. Lá, segundo o autor, a dinâmica social desenvolvida no interior das penitenciárias se comunica com a dinâmica social da cidade de modo muito intenso. A grande maioria dos moradores da cidade conhecem, são amigo, parentes ou são eles mesmos funcionários das prisões ${ }^{238}$.

Ao discutir dois aspectos principais o autor mostra como as dinâmicas dentro e fora adotam uma fluidez maior do que nas grandes cidades: o prestígio dos agentes penitenciários e as gírias típicas da cadeia que são utilizadas do lado de fora dos muros, não apenas por agentes, mas por moradores da cidade. Um comerciante entrevistado por ele verbaliza a sua percepção da cidade:

Uma coisa eu te digo: todo mundo nessa cidade tá condenado. Os presos porque roubaram e estão cumprindo sua pena; os agentes que ficam presos

\footnotetext{
${ }^{233}$ Polícia é a forma pejorativa que os presos se referem aos ASPs. A polícia é considerada pelos presos como inimigo.

${ }^{234}$ TAETS, Adriana Rezende Faria. Op. cit., p. 157.

235 SABAINI, Raphael. Uma cidade entre presídios: ser agente penitenciário em Itirapina - SP. 2012. Dissertação (Mestrado em Antropologia Social) - Faculdade de Filosofia, Letras e Ciências Humanas, Universidade de São Paulo, São Paulo. 2012.

${ }^{236}$ Penitenciária Dr. Antônio de Queiroz Filho, construída em 1978 (P I) e Penitenciária João Batista de Arruda Sampaio, construída em 1998 (P II). Idem, p.16.

237 “A política de interiorização das prisões tem como objetivo dar resposta rápida a um déficit crônico de vagas prisionais, além de ser, em curto espaço de tempo, uma tentativa (pouco eficaz) de contenção dos índices de violência.” Idem, p. 18.

238 Ibidem.
} 
nesse trabalho porque acham que ganham bem, e a gente, como comerciante, depende do dinheiro dos parentes de preso e do salário dos agentes. A gente que é do comércio acaba se sentindo preso, cada um à sua maneira. (comerciante). ${ }^{239}$

Sobre o uso das gírias típicas da cadeia na cidade $^{240}$, SABAINI desenvolve a argumentação no sentido de que os demais moradores acabam aprendendo algumas palavras típicas do ambiente prisional em razão do convívio próximo com os ASPs. Os agentes utilizam a linguagem da cadeia quando estão fora de serviço conversando uns com os outros e os parentes, amigos e vizinhos acabam aprendendo um pouco deste linguajar e utilizando-o. Contudo, algumas outras palavras continuam restritas ao ambiente interno da prisão. Segundo ele,

\begin{abstract}
A maneira de conversar na cidade, assim como também o conteúdo das conversas que circulam entre os diferentes tipos de pessoas de Itirapina, é modificada pela influência das cadeias. Este diferente jeito de se comunicar também cria diferentes tipos de sociabilidade, e a interação entre os agentes e seus amigos, parentes, moradores e comerciantes de Itirapina se reconfigura. ${ }^{241}$
\end{abstract}

Sobre o prestígio que os ASPs gozam na cidade ${ }^{242}$, SABAINI faz uma importante discussão acerca da política de interiorização das unidades prisionais. De acordo com ele, os agentes nas cidades grandes são estigmatizados.

\footnotetext{
O agente penitenciário é retratado em todas as obras utilizadas nesta pesquisa, como um funcionário mal remunerado, que habita bairros de periferia das grandes cidades, tendo que se proteger se o reconheçam, escondendo o uniforme e omitindo a profissão. O estigma (GOFFMAN, 1988) do agente penitenciário estabelece uma relação de diferença na identidade social do indivíduo, trata-se de um predicado que pode atribuir certo descrédito à pessoa do agente, assim como inferioriza seus valores de conduta em relação aos grupos com os quais se relaciona. O agente penitenciário estigmatizado fica à margem das demais pessoas, e os atributos do seu cotidiano se sujeitam ao julgamento depreciativo e à reprovação por parte das pessoas que não participam no universo intramuros. ${ }^{243}$
}

Já em Itirapina, o que o autor identifica é o oposto: os ASPs são prestigiados e são conhecidos por todos na cidade.

\footnotetext{
${ }^{239}$ Idem, p. 78.

${ }^{240}$ Idem, p. 85-114.

${ }^{241}$ Idem, p.85-86.

${ }^{242}$ Idem, p.115-148.

${ }^{243}$ Idem, p.116.
} 
Os salários são considerados altos para a qualificação exigida para o cargo e o padrão da cidade. Além disso, as garantias do funcionalismo público, em especial a estabilidade, facilitam o acesso a crédito e financiamento para os ASPs. Nas palavras do autor:

\begin{abstract}
O prestígio do Agente de Segurança Penitenciária que trabalha em Itirapina repousaria, primeiramente, nos "privilégios" dos salários e na estabilidade financeira do cargo de funcionário púbico, já que a cidade mostra-se como um lugar de poucas ofertas e opções de ocupação e a média salarial é inferior à remuneração de um guarda. As vantagens financeiras proporcionadas pelo emprego e observadas pela maioria da população em relação aos ASPs os colocam numa posição privilegiada dentro das redes de sociabilidade de Itirapina. O crédito facilitado no comércio, a aquisição de bens como eletroeletrônicos e automóveis são atrativos almejados por quem ainda não é agente, ao mesmo tempo em que são ostentados pelos que já conseguiram o emprego, sendo, portanto, sinônimo de ascensão econômica, colocando o agente penitenciário numa posição social privilegiada. ${ }^{244}$
\end{abstract}

Um agente entrevistado por ele traça a comparação entre ser ASP em São Paulo e no interior e destaca a diferença no custo de vida entre as duas cidades como um grande atrativo para seguir a carreira em cidade pequenas. De acordo com esse entrevistado por SABAINI,

Pra Itirapina é um salário excelente. Onde você vai ganhar o que se ganha no presídio? Quem não tem nível, ganha uns $\mathrm{R}$ \$ 2.200. O pessoal mais antigo chega a ganhar R\$ 3.000 por mês. Para São Paulo, é um salário pequeno, o custo de vida lá é muito alto. Mas para Itirapina... Que emprego vai pagar mais de R 2.000 só com colegial? Eu acho que a profissão de agente é bem vista pela maioria da população de Itirapina; eles não sabem o que a gente passa lá dentro, mas sabem que a gente ganha bem, ainda mais porque é difícil perder o emprego. (ASP). ${ }^{245}$

Outro ASP entrevistado por ele trata da questão da insegurança de ser agente em São Paulo como uma das desvantagens de seguir a profissão na capital. Ele também destaca a diferença no custo de vida entre as duas cidades e a oportunidade de emprego:

Se alguém disser que ser agente penitenciário em São Paulo é bom emprego, é porque está mentindo, porque a opção de empregos lá é maior. E tem mais: é complicado ser agente em uma cidade como São Paulo. É tudo muito caro e

\footnotetext{
244 Idem, p.125.

245 Idem, p.123.
} 
perigoso também. Graças a Deus que Itirapina é uma cidade pequena e tranquila, eu acho que isso ajuda na nossa profissão ser bem aceita por aqui. (ASP). ${ }^{246}$

A questão do prestígio do agente penitenciário e a comunicação entre a vida da cidade e a vida intramuros são os principais elementos discutidos pelo autor em sua dissertação, que apresenta caminhos interessantes de análise e agrega elementos para a compreensão do complexo universo do agente penitenciário.

\subsection{O Filme “A Experiência”}

O filme “A Experiência" ${ }^{247}$, lançado em 2004, relata a história do experimento realizado na Universidade de Standford, pelo professor Zimbardo, em 1971.

Inicialmente, uma equipe de cientistas arregimentou vinte pessoas, que nunca tiverem qualquer contato com a prisão, para uma vivência psicológica, em troca de um prêmio em dinheiro. Foram selecionados oito pessoas para assumirem o papel de guardas e outras doze pessoas para assumirem o papel de internos, em uma penitenciária isolada e monitorada pelos cientistas.

Esse retrato do filme é extremamente impactante e demonstra que o ambiente carcerário gera alterações profundas nas reações daqueles expostos aos estímulos que estão presentes em uma cadeia. Os que desempenharam a função de guardas realmente assumiram esse papel e o empenharam, inclusive com o emprego de violência física e moral, para manter a ordem e o poder. Aqueles que ficaram com o papel de presos resistiram de todas as formas.

A violência passou a imperar e, como se esquecessem de que aquilo era apenas uma “experiência” e de que poderiam alterar as regras do jogo, passaram a lidar com a situação como se fosse real.

\footnotetext{
${ }^{246}$ Idem, p.124.

247 Do original “Das Experiment”. HiRsChBIEGEL, Oliver. A Experiência. Direção de Oliver Hirschbiegel. Alemanha, 2001. $114 \mathrm{~min}$.
} 
Um dos elementos que mais chama atenção é a alteração do comportamento daqueles que representam os guardas, que se modifica em uma crescente agressividade.

A conclusão de Augusto Thompson e da pesquisa coordenada pelo Luiz Bogo CHIES, de que "o processo de prisionalização não se restringe, tão apenas, à massa carcerária”"248 é evidenciado nessa obra cinematográfica.

${ }^{248}$ ThOMPSON, Augusto. Op. cit., p. 52. 
Capítulo 3

CAPTANDO O OLHAR DO JUDICIÁRIO:

METODOLOGIA

Este capítulo apresenta a metodologia adotada na elaboração desta dissertação. Será relatada toda a construção metodológica, que teve como marco essencial o exame de qualificação e se baseou nos seguintes autores: Martin BAUER e George GASKELL ${ }^{249}$, Salo de CARVALHO ${ }^{250}$, Eva Maria LAKATOS e Marina de Andrade MARCONI ${ }^{251}$, Antônio Macena de FigueIREDo e Soraia Riva Goudinho SouzA ${ }^{252}$ e Nébia Maria Almeida de FIGUEIREDO ${ }^{253}$.

\subsection{Considerações preliminares}

A pesquisa proposta no exame de qualificação consistiu em uma análise jurisprudencial. A intenção era analisar como o Judiciário responde ao discurso e à posição assumida pelo ASP nos processos (como testemunha, vítima ou réu), discutir quais tipos de situação-conflito chegam ao conhecimento do Poder Judiciário e o seu posicionamento diante de problemas desenrolados no cárcere.

\footnotetext{
${ }^{249}$ BAUER, Martin W; GASKell, George. Pesquisa qualitativa com texto, imagem e som. Petrópolis: Vozes, 2002.

${ }^{250}$ CARvalho, Salo. Como (não) se faz um trabalho de conclusão: provocações úteis para orientadores e estudantes de direito (Especialmente das ciências criminais). Rio de Janeiro: Lumen Juris, 2011.

${ }^{251}$ LAKATOS, Eva Maria; MARCONi, Marina de Andrade. Metodologia do trabalho científico: procedimentos básicos, pesquisa bibliográfica projetos e relatório, publicações e trabalhos científicos. 7 ed. São Paulo: Atlas, 2008.

252 Figueiredo, Antônio Macena de; SouZA, Soraia Riva Goudinho. Projetos, monografias, dissertações e teses: da redação científica à apresentação do texto final. Rio de Janeiro: Lumen Juris, 2008.

253 FIGUEIREDO, Nébia Maria Almeida de. Método e metodologia na pesquisa científica. 3 ed. São Caetano do Sul/SP: Yendis Editora, 2008.
} 
A fonte escolhida para aquela análise foram os acórdãos proferidos pelo Tribunal de Justiça do Estado de São Paulo, ou seja, a análise se centraria nos elementos presentes nas decisões, de segunda instância, entre os anos de 1998 e 2010.

As decisões do Poder Judiciário, o que inclui os acórdãos, são registros oficiais, legais e públicos, que lhes confere uma especificidade única e que é bastante rica para a análise. Tal riqueza reside, dentre outras, no fato dos registros oficiais conterem o que os homens, por meio de uma instituição legal e oficial, decidiram transformar em registro do seu tempo e de sua atuação histórica. Por esse motivo, é bastante interessante analisar essas decisões oficiais, públicas e que são representações, exercício e expressões de Poder.

A intenção da pesquisa apresentada era fazer uma análise das representações oficiais, que seria realizada por meio do estudo da jurisprudência do Tribunal de Justiça do Estado de São Paulo, nas quais se pudesse aferir a forma como nelas é aceito, interpretado e valorizado o discurso do ASP, já que "tão importante quanto saber o que as pessoas fazem para além da lei e 'por baixo do pano' é saber o que elas elegem como legal e oficial: o que escolhem para deixar de registro de si mesmas e de seu tempo" 254 .

Durante o exame de qualificação propriamente dito, a banca composta pelo orientador desta pesquisa, Alvino Augusto de Sá, por Sergio Salomão Shecaira e Marcus Orione considerou, em discussão com a pesquisadora, mais interessante produzir um leve deslocamento do foco da pesquisa e, consequentemente, alterar a metodologia.

Deste profícuo debate resultou a alteração do objeto da pesquisa e, consequentemente, da fonte de dados. A nova etapa da pesquisa foi dedicada a entrevistar os próprios magistrados para saber qual a visão do Poder Judiciário sobre os agentes penitenciários; deste modo, não seria mais objeto da pesquisa o que os juízes ou desembargadores optaram por registrar nas decisões judiciais.

A necessidade de ir a campo, aliada à falta de literatura especializada sobre a temática, foram o norte no desenhar da metodologia do trabalho.

A pesquisa realizada é do tipo exploratória e, por essa razão, não foram estabelecidas hipóteses. A pesquisadora não teve contato com pesquisas feitas especificamente sobre esse assunto, não havendo, portanto, base empírica para se levantar

\footnotetext{
${ }^{254}$ SchritZMeYER, Ana Lúcia Pastore. Sortilégios de saberes: curandeiros e juízes nos tribunais brasileiros (1900-1990). São Paulo: IBCCrim, 2004. (Monografias IBCCRIM n. 29). p. 124.
} 
e se especificar hipóteses. Este é um trabalho, que poderá, no futuro, ensejar outras pesquisas ampliadas.

Para tanto, a metodologia desenhada foi a da realização de entrevistas semidirigidas com oito ${ }^{255}$ juízes que estivessem, à época em que as entrevistas foram realizadas, atuando em alguma das Varas de Execução Criminal do Estado de São Paulo.

Tal recorte foi adotado uma vez que os juízes da execução são aqueles que têm contato mais próximo com os agentes penitenciários, bem como com o sistema prisional propriamente dito. Lidam com o drama da Instituição Prisão e sua atuação profissional está direcionada ao dia a dia carcerário. São eles os responsáveis por julgar os procedimentos relativos à execução da pena e são também responsáveis por realizar visitas de inspeção às unidades prisionais para verificar e regular o funcionamento e as condições de detenção a que estão submetidos os presos.

O primeiro passo metodológico na construção da presente dissertação foi a realização de um cuidadoso levantamento bibliográfico. Neste momento, ficou claro que a literatura havia se dedicado pouco ao estudo da figura do agente penitenciário, além disso não se teve contato com nenhuma obra que tenha se dedicado, especificamente, ao olhar do Poder Judiciário sobre os ASPs. Deste modo, utilizou-se a bibliografia sobre a relação dos agentes penitenciários e o mundo do cárcere.

\footnotetext{
${ }^{255}$ Na realidade, a metodologia foi desenhada para a realização de dez entrevistas. Contudo, apenas oito foram realizadas; isso porque muitos juízes se recusaram a participar da pesquisa. Não se pode estabelecer a razão para essas recusas, mas talvez o momento sensível em matéria de Segurança Pública vivida no Estado de São Paulo, no segundo semestre de 2012, quando policiais militares e um número grande de civis foram assassinados, pode ter servido como uma barreira para a participação de juízes atuantes nas Varas de Execução Criminais do Estado na pesquisa. Este momento da história de São Paulo pode também ter influenciado as respostas dadas pelos juízes que participaram, que podem ter dado respostas mais precavidas, por estarem receosos. Para saber mais sobre este período, Vide RODRIGUES, Artur, et al. Violência em SP. Notícias, fotos e vídeos sobre "violência em SP". Estado de S. Paulo, 3 dez. 2012, 4 dez. 2012, 9 dez. 2012, 12 dez. 2012, 17 dez. 2012, 22 dez. 2012. Disponível em: <http://topicos.estadao.com.br/violencia-em-sp . Acesso em: 15 dez. 2012.

DONATO, Veruska. Onda de violência interrompe longo período de queda nos índices de SP. Jornal Hoje. Edição de: 27 nov. 2012. Disponível em: <http://g1.globo.com/jornal-hoje/noticia/2012/11/onda-deviolencia-interrompe-longo-periodo-de-queda-nos-indices-de-sp.html $\geq$. Acesso em: 15 dez. 2012.

SeCRETÁRIO de Segurança Pública de São Paulo deixa o cargo. G1. 21 nov. 2012. Disponível em: $<$ http://g1.globo.com/sao-paulo/noticia/2012/11/secretario-de-seguranca-de-sao-paulo-deixa-o-cargo.html $>$. Acesso em: 15 dez. 2012.

COM 4 HOMICíDIOS por dia, SP sofre com banalização da 'cultura do confronto'. Conectas Direitos Humanos, 26 out. 2012. Disponível em: <http://www.conectas.org/artigo-1/com-4-homicidios-por-dia-sp-sofre-combanalizacao-da-cultura-do-confronto?pg=4 $\geq$. Acesso em: 15 dez. 2012.
} 
Também foi importante para a fundamentação da pesquisa a bibliografia que se debruçou sobre a temática penitenciária e suas implicações, bem como a leitura de autores clássicos da Criminologia.

Além de fornecer as bases teóricas em uma perspectiva multidisciplinar para o trabalho, a leitura e a análise de textos foram importantes para a definição, com mais precisão, dos limites da pesquisa de campo. Ademais, foram essenciais para a discussão dos dados produzidos.

Apenas após a leitura bibliográfica pode-se traçar as questões que foram enfocadas na formulação das entrevistas com os juízes atuantes nas Varas de Execução Criminal.

\subsection{Técnica de produção dos dados}

A técnica de produção dos dados adotada foi a entrevista semidirigida.

O roteiro de entrevista semidirigida é composto por temas que devem guiar o entrevistador na condução da conversa de modo fluido e mais informal. Tais temas não podem servir de amarras para o entrevistador engessar a entrevista, ao contrário, eles funcionam como um norteador para que não se fuja da persecução do objetivo da pesquisa; mas sem impedir que novos elementos apareçam ou sejam abordados por outros ângulos. O entrevistado não precisa abordar todos os temas.

Durante as entrevistas, anotações pontuais foram realizadas e, posteriormente, complementadas pela pesquisadora logo após o término de cada entrevista.

O roteiro da entrevista, após as pequenas alterações sofridas a partir da experiência de três entrevistas piloto ${ }^{256}$, passou a conter os seguintes tópicos que nortearam as oito entrevistas realizadas:

- A visão da magistratura de Execução Penal sobre a figura do ASP no âmbito da execução penal.

- O posicionamento do Poder Judiciário diante dos conflitos ocorridos no cárcere que envolveram ASPs.

\footnotetext{
${ }^{256}$ Vide infra item 3.3.
} 
- A visão da magistratura sobre o discurso dos ASPs.

- O significado das falas dos ASPs nos processos e o que elas dizem sobre os acontecimentos dentro do cárcere.

- A existência de filtros aos conflitos ocorridos no cárcere, anteriores ao Judiciário.

- Percepções do Poder Judiciário sobre o ASP em seu papel de testemunha.

- Percepções do Poder Judiciário sobre o ASP em seu papel de vítima.

- A impressão que o Judiciário tem sobre a percepção que o ASP tem sobre o Judiciário.

- A valoração do depoimento do ASP pela magistratura.

- A visão do Poder Judiciário sobre o trabalho do ASP.

- A percepção do Poder Judiciário sobre corrupção e violência dos ASPs.

- A visão do Poder Judiciário sobre a relação que se estabelece entre o ASP e o cárcere, entre o ASP e o diretor da unidade prisional e entre o ASP e o preso.

\subsection{Pesquisa piloto}

Inicialmente foi construído um roteiro de entrevista semidirigida, após a leitura da base bibliográfica desta dissertação. Tal roteiro foi utilizado na realização de três entrevistas piloto.

Essa etapa inicial é fundamental para a realização de pesquisas de campo estruturadas e consistentes do ponto de vista metodológico. Nessa fase foi possível testar o roteiro produzido e fazer alguns pequenos ajustes antes da realização das oito entrevistas que se seguiram. A fase piloto serviu para testar o instrumental de produção de dados: sua compreensibilidade e sua eficácia para a consecução do objetivo da pesquisa.

Na pesquisa piloto foram entrevistados três juízes, dois deles já tiveram experiência nas Varas de Execução Criminal; e o terceiro juiz é atuante em uma Vara de Execução Criminal, mas fora do Estado de São Paulo. 
Com a pesquisa piloto realizada, foi possível fazer ajustes no roteiro de entrevista semidirigidas e criar as categorias de análise dos dados que seriam posteriormente produzidos. Tais categorias só foram consolidadas após a realização de algumas entrevistas, com o conhecimento do material já produzido.

\subsection{A amostra}

\subsubsection{O tamanho da amostra}

Foram entrevistados oito juízes que, na data da entrevista, estavam trabalhando nas Varas de Execução Criminal do Estado de São Paulo.

Por dever de sigilo e ética em pesquisa, não serão identificados os entrevistados e nem serão fornecidas informações que possam colocá-los em alguma situação de exposição ou que permita sua identificação. Para tanto, os juízes entrevistados serão identificados por números.

Esta amostra é bastante reduzida se for considerado o universo de juízes atuantes nas Varas de Execução Criminal no Estado inteiro. Somando-se às Varas que são exclusivamente de execução, com as demais que cumulam funções que incluem a execução criminal, são mais de 200 em todo o Estado ${ }^{257}$. Contudo, a amostra desta pesquisa é suficiente para possibilitar a formulação de hipóteses que poderão ser confirmadas ou refutadas por outras pesquisas no futuro.

A distribuição geográfica pelo Estado dos entrevistados favorece a construção de hipóteses mais consistentes, ao evitar que os dados produzidos sofram influência apenas da realidade peculiar de uma determinada região, ou seja, que sejam enviesados apenas em razão do contexto local ${ }^{258}$.

A amostra reduzida faz com que as conclusões desta dissertação não possam ser generalizadas - a análise que foi feita é qualitativa e não quantitativa - possibilita, tão somente, a formulação de hipóteses a serem, posteriormente, confirmadas por outras

${ }^{257}$ Esses dados foram obtidos a partir de contato telefônico e por email com o Tribunal de Justiça de São Paulo. Para mais detalhes, vide anexo 1.

${ }^{258}$ Vide infra item 3.4.4. 
pesquisas. Como já dito acima, a pesquisa é do tipo exploratória, ou seja, não partiu de hipóteses; contudo, novas pesquisas sobre a temática poderão partir das hipóteses que foram formuladas em sede de conclusão a partir da realização da presente pesquisa.

\subsubsection{Formação da amostra: critérios de inclusão}

Os critérios para inclusão de juízes na amostra da pesquisa foi baseado no fato de estarem atuando em Varas de Execução Criminal do Estado de São Paulo, à época da realização da entrevista, e estarem distribuídos nas regionais - de acordo com o critério adotado pela Secretaria de Administração Penitenciária (SAP) - para se evitar que as respostas pudessem ser enviesadas em razão da realidade de uma regional específica.

Foram entrevistados dois juízes que atuam na regional metropolitana de São Paulo, dois juízes que atuam na região central, um juiz atuante na região do Vale do Paraíba e Litoral, dois juízes responsáveis por processos e unidades prisionais da regional oeste e um da região noroeste.

\subsubsection{A composição da amostra}

No que diz respeito ao recorte espacial, os oito juízes entrevistados atuam nas cinco regiões administrativas utilizadas pela Secretaria de Administração Penitenciária. Portanto, as entrevistas permitiram uma cobertura ampla do Estado de São Paulo, não tendo se localizado em uma região específica. Desta forma, os dados levantados tendem a não ser enviesados em razão de peculiaridades específicas de uma ou outra região.

Abaixo será traçada uma pequena descrição de cada região para que se possa contextualizar a pesquisa.

Foi adotado como critério a divisão utilizada pela SAP e não por outros órgãos, exatamente por ser esta a secretaria responsável pela administração do sistema penitenciário no Estado de São Paulo e, portanto, ter relação direta com o objeto da pesquisa. 


\subsubsection{Regiões administrativas da Secretaria de Administração Penitenciária}

O Estado de São Paulo é a unidade da federação campeã em número de presos. De acordo com dados de 25 de outubro de 2012, da Secretaria de Administração Penitenciária, o Estado possuía 182.581 pessoas presas, distribuídas em 149 unidades prisionais ${ }^{259}$. Além destas 149 unidades, a SAP também gerencia três hospitais de custódia e tratamento ${ }^{260}$.

O número de agentes penitenciários no Estado de São Paulo é de 23.199. De acordo com a resposta ao pedido de acesso à informação pública realizado, em cada Penitenciária do Estado trabalham 180 ASPs; e, em cada Centro de Detenção Provisória, trabalham 165 $\operatorname{ASPs}^{261}$.

Isso representa, no Estado de São Paulo, a proporção de um ASP para cada oito presos. Mas, para compreender melhor esta proporção é preciso levar em consideração que os agentes penitenciários trabalham em regimes de plantão e que o número total de agentes inclui aqueles que estão de licença, em desvio de função, em férias e, talvez, até os aposentados.

Abaixo serão apresentados os dados desagregados disponíveis para cada uma das cinco regiões da $\mathrm{SAP}^{262}$. É importante destacar a dificuldade em ter acesso aos dados referentes ao sistema prisional, aos agentes penitenciários ${ }^{263}$ e até mesmo sobre a organização do Tribunal de Justiça. Por esta razão, foi necessário utilizar a lei de acesso à informação pública para conseguir acesso a mais dados sobre os agentes penitenciários.

259 Dados divulgados no Portal da Secretaria da Administração Penitenciária do Estado de São Paulo. Disponível em: <www.sap.sp.gov.br>. Acesso em: 1 nov. 2012.

${ }^{260}$ Idem.

${ }^{261}$ Para ter acesso a este dado foi realizado um pedido formal de acesso à informação pública endereçado à Secretaria de Administração Penitenciária. Tal pedido foi realizado utilizando-se o Serviço de Informação ao Cidadão - SIC, e teve como base a Lei de Acesso à Informação Pública - Lei 12.527/2011. O dado que foi requisitado referia-se a quantos agentes penitenciários trabalham em cada unidade prisional do Estado. Porém, a resposta recebida foi reunida por “tipo” de unidade. Vide anexo III. O dado público disponível é referente a junho de 2012 e, de acordo com essa informação, eram 23.323 agentes penitenciários em todo o Estado. MinistÉRIO DA JusTiÇA. Departamento Penitenciário Nacional. Sistema integrado de informações penitenciárias - InfoPen. São Paulo/SP. Referência 06/2012. Disponível em: $<$ http://portal.mj.gov.br/main.asp?View=\%7BD574E9CE-3C7D-437A-A5B6-

22166AD2E896\%7D\&Team=\&params=itemID=\%7BC37B2AE9-4C68-4006-8B16-

24D28407509C\%7D;\&UIPartUID=\%7B2868BA3C-1C72-4347-BE11-A26F70F4CB26\%7D>. Acesso em: 23 dez. 2012.

${ }^{262}$ Todas as informações das regiões citadas a seguir estão disponíveis em <http://www.sap.sp.gov.br>. Acesso em: 21 dez. 2012.

${ }^{263}$ A mesma questão foi constatada por ADRIANA REZENDE FARIA TAETS, em sua pesquisa, quando afirmou que “construir um panorama voltado para a profissão da agente de segurança penitenciária no Estado de São Paulo não é tarefa simples, já que dados referentes ao sistema prisional do Estado são, como um todo, de difícil acesso.” Op. cit., p. 46. 


\section{Região Metropolitana de São Paulo}

A região metropolitana de São Paulo tem oito Penitenciárias, 17 Centros de Detenção Provisória (CDP) e três Centros de Progressão Penitenciária (CPP), totalizando 28 unidades prisionais.

A capacidade das oito Penitenciárias somadas é de 8.039 vagas, porém, 14.140 pessoas estão presas nelas. A capacidade de vagas em todos os Centros de Detenção Provisória desta região é de 10.182. O número de pessoas presas nestas unidades chega a 28.282. Já nos Centros de Progressão Penitenciária, a capacidade total da região é para 2.100 pessoas, mas 2.732 estão ali custodiadas. No total, a Secretaria de Administração Penitenciária dispõe de 20.321 vagas para as 45.154 pessoas privadas de liberdade na região metropolitana de São Paulo.

Foram entrevistados dois juízes atuantes nesta região.

\section{Região do Vale do Paraíba e Litoral}

A região do Vale do Paraíba e Litoral conta com oito Penitenciárias, sete Centros de Detenção Provisória, dois Centros de Progressão Penitenciária e um Centro de Ressocialização (CR), totalizando 18 unidades prisionais.

As oito Penitenciárias juntas têm capacidade para 3.441 e contam com 4.765 presos. Já nos CDPs, estão privados de liberdade 11.673 pessoas e a capacidade é de 4.864 vagas. Nos CPPs existem 2.020 vagas, sendo que 3.270 pessoas estão custodiadas nestas duas unidades. No único CR da região, 100 pessoas estão presas, sendo que a capacidade da unidade é de 174. Na região do Vale do Paraíba e Litoral estão presas 19.808 pessoas dispostas em 10.499 vagas.

Foi entrevistado um juiz atuante nesta região. 


\section{Região Noroeste}

A região noroeste possui 36 unidades prisionais, sendo 20 Penitenciárias, seis Centros de Detenção Provisória, três Centros de Progressão Penitenciária e sete Centros de Ressocialização (CR).

Nas 20 penitenciárias, a SAP disponibiliza 16.504 vagas, mas 28.043 pessoas estão presas nestas unidades. O número de vagas nos CDPs é 4.396 e estão custodiados 6.058 presos nestas unidades. Nos CPPs estão 3.434 pessoas em 1.792 vagas. Já os Centros de Ressocialização da região possuem mais vagas do que pessoas presas. A capacidade é para 1.266 e ali estão 1.225 pessoas. No total, 38.760 pessoas estão presas na Região Noroeste, que possui capacidade para abrigar 23.958 pessoas.

Foi entrevistado um juiz atuante nesta região.

\section{Região Central}

A região central tem 31 unidades prisionais, sendo 13 Penitenciárias, oito Centros de Detenção Provisória, dois Centros de Progressão Penitenciária e dez Centros de Ressocialização.

As Penitenciárias abrigam 20.509 presos em 10.379 vagas. Os CDPs também operam acima de sua capacidade, são 9.441 presos custodiados para 4.004 vagas. Os CPPs possuem 1.498 vagas e ali estão 3.092 presos. Nos CRs a situação é contrária, existem mais vagas do que presos. São 1.932 vagas para 1.753 presos. No total, a Região Central do Estado dispõe de 17.813 vagas e possui 34.795 presos.

Foram entrevistados dois juízes atuantes nesta região.

\section{Região Oeste}

São 36 unidades prisionais na Região Oeste. Destas 36 unidades, 26 são Penitenciárias, dois são Centros de Detenção Provisória, três são Centros de Progressão 
Penitenciária, quatro são Centros de Ressocialização e uma unidade é de Regime Disciplinar Diferenciado (RDD).

Estão presas nas Penitenciárias da Região Oeste 36.854 pessoas em 21.880 vagas. São 2.754 pessoas em um espaço planejado para 1.536, nos CDPs da região. Os três CPPs têm capacidade total para 2.392, porém estão custodiados ali 3.588 pessoas. Os CRs e a única unidade de RDD não estão com excesso de pessoas: os CRs têm capacidade para 840 presos e abrigam 830. No mesmo sentido, a unidade de RDD tem 38 presos e foi projetada para 160 pessoas. A Região Oeste possui 44.064 presos para 26.808 vagas.

Foram entrevistados dois juízes atuantes nesta região.

\subsubsection{Critérios de acesso aos sujeitos da pesquisa}

A forma de agendamento das entrevistas foi, em geral, sem apresentação por parte de um terceiro. Eram realizados telefonemas para os números disponíveis no site do Tribunal de Justiça e a pesquisadora apresentava-se, bem como apresentava o objetivo da pesquisa para o magistrado ou para seu assessor ou para o chefe de gabinete. A partir de então, eram agendados uma data e um horário. As entrevistas foram realizadas presencialmente - na sala de audiência ou no gabinete do magistrado -, no fórum em que o juiz atua. Em outros casos, a facilidade de acesso ou de contato com o juiz foi utilizada como critério de acesso.

A dificuldade maior residiu em conseguir encontrar a pessoa responsável pelo agendamento da entrevista no telefone disponível na internet. Eram necessárias muitas tentativas por telefone, em diferentes dias, até conseguir-se chegar à pessoa responsável e diversas vezes fez-se necessário conversar com o próprio magistrado para apresentar os objetivos da pesquisa. Após o contato, a dificuldade residia na disponibilidade de agenda do juiz. 


\subsection{Condução das entrevistas}

É conveniente que, em pesquisas exploratórias, o pesquisador faça as perguntas da maneira mais aberta possível, a fim de não induzir as respostas e possibilitar que os entrevistados respondam de forma livre.

Na presente pesquisa algumas questões foram aprofundadas em função do que o entrevistado tinha a dizer e mostrou-se disposto a aprofundar e outras foram abordadas de forma mais breve, sem forçar uma manifestação do entrevistado e, também, para não tornar a entrevista demasiadamente longa, já que os entrevistados estavam em seu horário de trabalho. Por estas razões, nem todas as categorias de análise estiveram presentes em todas as entrevistas.

Em alguns casos, apenas a apresentação do título da pesquisa foi suficiente para que o entrevistado discorresse sobre o tema. Nesses casos, deixava-se a palavra livre para o entrevistado e depois, a pesquisadora fazia indagações com o intuito de complementar itens que foram espontaneamente abordados pelos sujeitos e indagando-lhes sobre o que ainda não havia sido explorado.

Mas, em outros casos, apenas a apresentação do título da pesquisa não era suficiente para estimular a fala do entrevistado. Nestes casos, o roteiro de entrevista era seguido.

\subsection{Forma de análise dos resultados}

A metodologia adotada foi aquela compatível com pesquisas qualitativas - e não quantitativas. Portanto, a metodologia possibilitou traçar elementos aferidos qualitativamente a partir da análise detida dos dados. Não se podendo chegar a conclusões generalizantes, já que não se realizou uma pesquisa com uma amostra suficiente para tal e nem uma pesquisa quantitativa com caráter estatístico.

Deste modo, por ser uma pesquisa qualitativa, é possível identificar percepções e entendimentos sobre a questão colocada, a partir da interpretação dada pela pesquisadora no cotejamento entre os dados produzidos e a bibliografia estudada. Podendo-se 
desenvolver conceitos e hipóteses explicativas, e não teorias que sejam aplicáveis a todo universo.

Foi realizada uma discussão e uma análise mais detida e interpretativa sobre os elementos que apareceram nas entrevistas, não se buscando elementos quantificáveis, mas sim passíveis de serem considerados em sua dimensão qualitativa. Como não se teve a intenção de projetar resultados para todo o universo do Poder Judiciário, o número de entrevistas foi pequeno, permitindo, assim, uma análise mais cuidadosa de todos os elementos.

\title{
De acordo com NÉBIA MARia AlMEIDA DE FigueIREDO,
}

\begin{abstract}
As pesquisas qualitativas trabalham com dados não quantificáveis, coletam e analisam materiais pouco estruturados e narrativos, que não necessitam tanto de uma estrutura, mas em compensação, requerem o máximo de envolvimento por parte do pesquisador. Dessa forma, esse tipo de pesquisa produz grandes quantidades de dados narrativos, dispensando grandes amostras, visto que o pesquisador qualitativo tem de evitar controlar a pesquisa, para que o estudo permaneça no contexto naturalista. ${ }^{264}$
\end{abstract}

Deve-se ressaltar que a presença da subjetividade daquele que pesquisa sempre influencia tanto a coleta de dados quanto a discussão e interpretação destes. A pesquisa em Criminologia não está isenta de contaminações com as concepções, trajetória e escolhas do próprio pesquisador. A mesma pesquisa realizada por pesquisadores diferentes poderiam resultar em análises diversas. Aí reside a riqueza e a complexidade da pesquisa em ciências humanas e deve estar presente no radar do leitor ao ter acesso aos resultados alcançados e às interpretações dadas a esses resultados ${ }^{265}$. Para ANITUA isso fica ainda mais aflorado no âmbito da Criminologia.

\footnotetext{
${ }^{264}$ Figueiredo, Nébia Maria Almeida de. Op. cit.,. p. 96-97.

265 “Os papéis de entrevistador e entrevistado compartilham certa não reversibilidade pragmática, ou seja, o direito - e o afã - quase unilateral de perguntar, que dá lugar ao desdobramento (ou recuo) da resposta esperada. Em ambos os casos, o produto obtido será de autoria conjunta, indissociável da cena da interação, da subjetividade colocada em jogo, da marca do jornalista/pesquisador - que propõe um percurso mais ou menos delimitado - da confrontação discursiva dos respectivos esquemas valorativos. Nada do que ocorrer no transcurso do encontro terá uma existência independente em outro lugar, por mais que remeta a 'fatos' verdadeiramente ocorridos.” ARFUCH, Leonor. O espaço bibliográfico. Dilemas da subjetividade contemporânea. Rio de Janeiro: Eduerj, 2010. Apud TAETS, Adriana Rezende Faria. Op. cit., p. 36.
} 
Para ele, “a 'Criminologia' e a 'Política Criminal', como toda atividade essencialmente política, não constituem uma atividade neutra e inocente”266.

Foram dez as categorias de análise criadas a partir da realização das três entrevistas piloto e que foram sedimentas e reformuladas a partir do material obtido nas oito entrevistas subsequentes.

Tais categorias de análise surgiram da verificação de temas que apareceram recorrentemente nas entrevistas. Os diversos temas foram estruturados de modo a fornecer uma noção geral dos dados, mas deixando espaço, também, para a discussão das singularidades - exatamente por se tratar de pesquisa qualitativa.

Para que se pudesse analisar as entrevistas, o conteúdo de cada uma delas foi classificado de acordo com as categorias, sendo lançados os trechos das entrevistas que se encaixavam nas categorias. Quando nada da entrevista se encaixava em determinada categoria, essa ficava em branco para aquele entrevistado.

As categorias de análise criadas serão apresentadas abaixo, juntamente com uma pequena súmula explicativa.

- Preparo, papel e formas de atuação do ASP:

Nesta categoria foram incluídas as falas que diziam respeito à formação dos agentes penitenciários, aos requisitos necessários para ser ASP, ao papel na execução penal e na condução do dia a dia carcerário, às funções que exercem e de que forma desempenhamnas, na visão do Poder Judiciário.

- Relacionamento entre os ASPs e o Poder Judiciário:

Nesta categoria foram englobados os elementos que surgiram nas entrevistas que dizem respeito à relação que se estabelece entre os agentes penitenciários e o Poder Judiciário e a figura do juiz - enquanto representante do Poder Judiciário.

\footnotetext{
266 ANITUA, Gabriel Ignacio. Op. cit., p. 27-28. "Não pretendo aqui, pois, colocar-me no lugar do politicamente 'neutro', nem negar meus próprios conceitos sobre o que é bom ou mau. Quem escreve estas linhas sabe que não se atua a partir do lugar da 'neutralidade' (inexistente na atividade humana - desconfie, amigo leitor, de quem defende, pois não só pode ser 'medíocre', como também pode estar 'mal intencionado’).” ANITUA, Gabriel Ignacio. Op. cit., p. 23.
} 
- Relacionamento entre os ASPs e os presos:

Esta categoria diz respeito ao relacionamento que é estabelecido entre os agentes penitenciários e os presos na unidade prisional em que atuam, na perspectiva do Poder Judiciário.

- Relacionamento entre os ASPs e a direção da unidade prisional em que trabalham:

Aqui foram incluídos os elementos que tratam da relação estabelecida entre os agentes penitenciários e a direção da unidade prisional em que trabalham, no olhar do Judiciário.

- Probidade dos ASPs:

Esta categoria inclui os elementos que surgiram nas entrevistas e se relacionam com a honestidade, abuso no exercício profissional, corrupção e violência praticados, ou não, por agentes penitenciários.

- Vulnerabilidade e segurança do ASP no exercício da sua profissão:

Este item aborda as questões relativas aos fatores de insegurança que envolvem o exercício profissional do agente penitenciário, na visão do Poder Judiciário.

- Valorização, por parte do Poder Judiciário, do depoimento do ASP:

Aqui são alocados os trechos das entrevistas que dizem respeito à forma que o Poder Judiciário valoriza o depoimento prestado por um agente penitenciário em um processo disciplinar contra um preso, em geral, procedimento de apuração de cometimento de falta grave. 
- Condições de trabalho do ASP:

Esta categoria aborda as condições de trabalho às quais estão submetidos os agentes penitenciários, na visão do Poder Judiciário.

- Fatores emocionais relacionados ao trabalho do ASP:

Esta categoria trata dos elementos e dos impactos emocionais implicados no exercício da profissão de agente penitenciário, de acordo com o Poder Judiciário.

- Impacto da existência do crime organizado na atuação do ASP:

Aqui são abordados os elementos que o Poder Judiciário percebe no que diz respeito à existência de grupos de presos organizados e a influência que exercem no desempenho da função do ASP.

A partir da organização do conteúdo das entrevistas nas categorias de análise acima descritas, os resultados obtidos foram apresentados e analisados ${ }^{267}$. Após, passou-se à discussão e à interpretação dos resultados ${ }^{268}$ obtidos à luz da bibliografia utilizada como referência ${ }^{269}$. A discussão e interpretação permitiu a extração de cinco grandes linhas perceptivas do Poder Judiciário acerca dos agentes penitenciários. Estas grandes linhas são: a função do ASP - ressocializadora vs. disciplinar -; o poder do ASP perante os presos; a influência da facção criminosa no trabalho do ASP; os impactos psicossociais do trabalho do ASP e o contexto de atuação do $\mathrm{ASP}^{270}$.

\footnotetext{
${ }^{267}$ Vide infra capítulo 4.

${ }^{268}$ Vide infra capítulo 5.

${ }^{269}$ Vide supra capítulo 2.

${ }^{270}$ Vide infra capítulo 6.
} 
Capítulo 4

O OLHAR DO JUDICIÁRIO:

\section{APRESENTAÇÃO E ANÁLISE DOS DADOS}

Este capítulo destina-se a apresentar e a analisar os dados produzidos nas oito entrevistas realizadas com os juízes atuantes nas Varas de Execução Criminal do Estado de São Paulo ${ }^{271}$, acerca das percepções e valorações que o Poder Judiciário tem da categoria profissional dos agentes penitenciários.

A tabela que será apresentada ao final deste capítulo é uma síntese dos dados produzidos a partir das entrevistas. Os trechos das entrevistas foram alocados nas categorias pertinentes. Nos casos em que determinado trecho se encaixava em mais de uma categoria, a afirmação foi reproduzida nas categorias pertinentes.

A tabela deve ser lida vertical e horizontalmente. À leitura vertical compete a demonstração dos elementos que apareceram em cada entrevista, separadamente, permitindo ao leitor conhecer como foram cada uma delas. Tal leitura faz com que se acompanhe o raciocínio desenvolvido por cada entrevistado.

Já a leitura horizontal possibilita a visualização de todos os elementos que dizem respeito a cada uma das dez categorias de análise. Permite comparações entre os dados coletados em cada uma das entrevistas e a compreensão da categoria de forma mais completa e direta; uma vez que em uma linha estão aglutinados todos os elementos que dizem respeito àquela temática que foram desenvolvidos pelos entrevistados.

Abaixo serão apresentadas ambas as leituras, começando pela vertical e, em seguida, pela horizontal.

\footnotetext{
${ }^{271}$ Para garantir o sigilo da identidade dos entrevistados, como já detalhado no capítulo 3, os juízes foram numerados e não serão fornecidas informações sobre a comarca e tampouco a região do Estado em que atuam. Além disso, com a mesma finalidade, todos os entrevistados serão tratados pelo gênero masculino, apesar de terem feito parte da pesquisa magistrados homens e mulheres. Também não serão apresentadas informações sobre a biografia e/ou o currículo dos entrevistados.
} 


\subsection{Leitura Vertical}

Foram realizadas oito entrevistas. Cada uma delas perpassou praticamente todas as categorias de análise.

\subsubsection{Juiz 1}

O conteúdo colhido nesta entrevista se aplicou às dez categorias.

De acordo com o juiz, no Estado do Rio de Janeiro é preciso ter nível superior para ser agente penitenciário. Em São Paulo, há falta de preparo intelectual por parte dos agentes para que atendam aos objetivos da execução penal. Os ASPs não recebem capacitação em primeiros socorros, psicologia, pedagogia e idiomas - o que seria importante para atender aos presos estrangeiros - e deveriam receber.

Nesta entrevista foi afirmado que os ASPs têm um papel fundamental na execução penal, já que desenvolvem dois papéis principais: (i) orientação e acompanhamento na ressocialização ${ }^{272}$; (ii) monitoramento da disciplina e do cumprimento das normas. Nesse sentido, o ASP é o parceiro do Estado no objetivo da recuperação do preso, uma vez que o objetivo da execução penal é a recuperação.

Por esse motivo, o termo “carcereiro” é impróprio para denominar esta profissão. Os ASPs atuam na ponta, sendo o elo de ligação entre o Estado e o preso. Fazem a mediação no dia a dia, entre os presos e a Administração da Unidade Prisional. E, ao mesmo tempo, exercem uma função de fiscalização. Sendo assim, cabe ao ASP fiscalizar, monitorar e auxiliar os presos.

Os ASPs não têm contato com os juízes, uma vez que o contato que se estabelece é entre os juízes e os diretores das unidades prisionais. Contudo, apesar do pouco contato, a

\footnotetext{
${ }^{272}$ Não serão feitas distinção e nem problematização entre os termos "ressocialização", "reintegração social" e "recuperação". Serão utilizados como sinônimos ao longo da dissertação. Para mais informações sobre essa discussão, vide BARATTA, Alessandro. Por Un Concepto Crítico de Reintegración Social del Condenado. In: OLIVEIRA, E. (Coord.) Criminologia Crítica (Forum Internacional de Criminologia Crítica). Belém: CEJUP, 1990. BARATTA, Alessandro. Ressocialização ou Controle Social: Uma abordagem crítica da "reintegração social” do sentenciado. Disponível em: <http://www.juareztavares.com/textos/baratta_ressocializacao.pdf>. Acesso em: 15 jan. 2012. SÁ, Alvino Augusto de. Criminologia Clínica e Execução Penal: proposta de um modelo de terceira geração. São Paulo: RT, 2011.
} 
relação entre o Poder Judiciário e os ASPs é muito boa; é uma relação de respeito e não de temor. É muito boa a recepção do ASP para com o juiz que visita a unidade prisional.

O Poder Judiciário recebe denúncias e representações feitas pelos ASPs contra a direção da unidade prisional e também feita pelo preso contra os ASPs.

A profissão possui alto grau de risco para o ASP e para sua família. Este fator - alto grau de risco - é gerador de impacto psicológico sobre os ASPs, que possuem temor em razão de tal alto risco.

Sobre as condições das unidades prisionais, elas são negativas para os funcionários e para os presos. Para os funcionários, porque deixa-os expostos à violência e, para os presos, por conta da superlotação. As condições de trabalho são ruins, devido à carência de recursos humanos e materiais e ao excesso de demanda - superlotação.

O Poder Judiciário confere presunção relativa de veracidade ${ }^{273}$ ao depoimento do ASP em processos no âmbito da execução penal. Não é estabelecida diferença no peso conferido à palavra do ASP, no processo, - ou de qualquer outro agente público - com relação a qualquer outro depoente que não exerça a função pública.

A presença de facções criminosas produz impacto no trabalho do ASP, além de impactar a ordem pública e o cotidiano prisional. As facções dificultam a reinserção social dos presos. Existe uma oposição entre as lideranças dos presos e a atividade disciplinar da administração. A liderança do preso é um poder paralelo e é altamente negativa: as facções intimidam alguns servidores e cooptam outros, através do dinheiro ou de imposição do temor e das ameaças.

Existe uma minoria de agentes penitenciários que é corrupta ou que comete desvios no desempenho da função, mas o entrevistado deixa claro que não se pode estigmatizar o servidor penitenciário por causa de uma minoria.

\footnotetext{
${ }^{273}$ A regra processual penal é de que a parte que alega determinado fato deve prová-lo. O Direito fixa espécies de presunções que geram exceções a essa regra geral. As entrevistas apresentadas na dissertação abordam duas destas espécies: a presunção relativa e a presunção absoluta. A presunção absoluta é chamada de jure et de jure. É aquela em que o juiz não considera outras provas, dando como verdadeiro o fato narrado. A presunção absoluta é uma ficção jurídica. Já a presunção relativa, chamada de juris tantum, é aquela que admite contraprova. Nesta situação, cabe ao interessado ou ao acusado - e não a quem fez a alegação, como é a regra processual penal - comprovar que o fato alegado não é verdadeiro.
} 


\subsubsection{Juiz 2}

Nesta entrevista não foram identificados dados relativos a três categorias de análise: categoria 4: Relacionamento entre os ASPs e a direção da unidade prisional em que trabalham; categoria 5: Probidade; e categoria 10: Impacto da existência do crime organizado na atuação do ASP.

Aparece como importante que os agentes penitenciários recebessem preparo sociológico para o exercício de sua função. Foi abordado o assunto que não são realizados investimentos suficientes na capacitação e nem na remuneração destes profissionais. Estes investimentos poderiam, inclusive, afastar tendências à “facilidade”, ou seja, poderiam reduzir o risco de que os agentes penitenciários acabassem agindo de modo corrupto.

A função do ASP é muito importante no dia a dia da vida prisional, é de altíssima relevância para a ressocialização. Os ASPs são responsáveis pelo processo de ressocialização e também pelo aspecto disciplinar. Antes eram apenas guardas de presídios, mas isso mudou. São considerados como a primeira trincheira que o sentenciado tem ao ingressar no sistema prisional. Os ASPs identificam os problemas de disciplina e de grupos. São as principais testemunhas do que ocorre no presídio. São responsáveis pelo funcionamento completo do presídio, inclusive auxiliam os técnicos ${ }^{274}$.

Ser agente penitenciário não é uma tarefa fácil e nem estimulante, é necessário ter vocação.

Os ASPs são testemunhas das faltas que os presos cometem, também é comum serem vítimas de ameaças e agressões. O Poder Judiciário supõe que seja comunicado de todas as faltas graves que ocorrem, para poder exercer o seu papel.

Os ASPs recebem bem o juiz nas inspeções que realizam nas unidades prisionais, até porque a tarefa do juiz é a de verificar a regularidade do presídio e não fiscalizar o trabalho dos ASPs. Não existe uma relação de temor hierárquico. Essa inspeção mensal é muito importante para o juiz saber do dia a dia do ASP, da pressão que está sofrendo.

Os ASPs têm a mesma percepção que os demais cidadãos têm sobre o Poder Judiciário - percebem os méritos e também as mazelas.

\footnotetext{
${ }^{274}$ Técnicos são os psicólogos, médicos e assistentes sociais que são contratados pelo Estado para realizar o acompanhamento e atendimento dos presos.
} 
Os ASPs estão submetidos ao risco de contaminação por doenças, a situações de violência e de crimes. Não é positivo que o ASP porte arma dentro do presídio.

No que diz respeito à valoração do depoimento do ASP, o Tribunal de Justiça de São Paulo tem o entendimento de que cada caso deve ser analisado individualmente, sendo, portanto, a fé pública ${ }^{275}$ relativa.

Por fim, as condições de trabalho são ruins em função da superlotação das unidades prisionais, o que é uma realidade em todo o Estado de São Paulo.

\subsubsection{Juiz 3}

Esta entrevista deixou de apresentar material para a análise de duas categorias: categoria 7: Valorização, por parte do Poder Judiciário, do depoimento do ASP e categoria 10: Impacto da existência do crime organizado na atuação do ASP.

De acordo com este entrevistado, a maioria dos ASPs é melhor profissional do que se pode imaginar. Existem ASPs que são vocacionados para o exercício da função.

Eles são comumente testemunhas de porte de drogas e de celular por parte dos presos. Mas presenciar presos portando armas é raro.

Os ASPs fazem de tudo dentro da unidade prisional, são responsáveis pela “tranca”276, "banho de sol”,277, escolta para audiências e para hospitais.

\footnotetext{
${ }^{275}$ A fé pública é um conceito jurídico que representa a credibilidade conferida aos agentes públicos no exercício de suas funções. A fé pública inverte o ônus da prova e opera como a presunção relativa, explicada acima, porém apenas para alguns agentes do Estado. Sendo assim, presumem-se verdadeiras as declarações destes funcionários públicos até que se prove o contrário.

276 "Tranca" é o termo utilizado para se referir ao momento e ao processo de trancar e destrancar as celas no horário determinado, de acordo com as regras da direção da unidade. Além de trancar e destrancar as celas no horário previsto, é necessário fazer a contagem dos presos, para checar se houve fuga ou morte. Em geral, o horário de destrancar as celas é às $8 \mathrm{~h}$ e o horário de trancar é às $16 \mathrm{~h}$.

277 "Banho de sol” é o momento em que os presos não estão trancados em suas celas, ficando todos soltos em um espaço aberto, comumente denominado de pátio (normalmente das $8 \mathrm{~h}$ às $16 \mathrm{~h}$ ). Em geral, cada raio das unidades prisionais tem um pátio e os presos têm direito a desfrutar do banho de sol no seu próprio raio, não tendo comunicação ("trânsito") com os presos dos outros raios. Em muitas unidades masculinas, o pátio é ocupado por uma quadra de futebol. Nas unidades de segurança máxima ou de Regime Disciplinar Diferenciado, o banho de sol se dá em um espaço aberto anexo à cela individual em que o preso está ocupando. Nestas unidades o banho de sol é individual, não havendo contato com outros presos e a duração do banho de sol é muito restrita, apenas de uma a duas horas por dia.
} 
Os juízes tem pouco contato com os ASPs. O contato é mais intenso com os diretores gerais e com os diretores de área, em especial com o de disciplina ${ }^{278}$. Nas visitas de inspeção, os juízes conversam com os diretores e com os presos.

O juiz não fica sabendo de tudo o que acontece no presídio, são poucos casos de irregularidade e abusos praticados por ASPs que chegam ao conhecimento do Poder Judiciário.

As faltas graves cometidas pelos presos sempre chegam ao conhecimento do Poder Judiciário que, em alguns casos, cancela-as, por exemplo, quando a gravidade do xingamento proferido pelo preso contra um ASP é pequena. Não é comum que os ASPs forjem faltas cometidas pelos presos. Isso depende do estabelecimento prisional e também da forma como o diretor conduz a unidade, mas em muitos lugares a relação de convivência entre os presos e os ASPs é tranquila, não de inimigos, já que os ASPs fazem o possível para ajudar os presos.

O diretor sabe tudo o que acontece na unidade, mas em geral não faz questão de apurar os abusos cometidos por ASPs. A posição da chefia reflete nas ações dos subordinados e a relação é fluida. A relação de confiança que existe entre o diretor e os ASPs depende tanto do perfil do diretor quanto dos agentes que atuam naquela unidade, não é possível generalizar. Nos Centros de Ressocialização a relação entre diretor e ASP é de proximidade e de confiança, por serem unidades menores.

A questão da probidade dos agentes varia em razão da unidade prisional, algumas tem maior tolerância à prática de abusos - em termos de violência e corrupção. Isso depende bastante da posição assumida pelo diretor, já que, segundo o entrevistado, a conduta da chefia reflete nas ações dos subordinados.

A instituição da Polícia Civil tem cultura de tolerância a abusos, a carreira de agente penitenciário tem menos. São poucos os casos de abusos praticados por ASPs que são denunciados pelos presos, e quando o fazem é sem a indicação de nomes ou datas, o

\footnotetext{
${ }^{278}$ Em regra, nas unidades prisionais há um diretor geral da unidade e diretores responsáveis por áreas específicas, como disciplina, educação e trabalho. Os diretores gerais são escolhidos e nomeados pelo Secretario de Administração Penitenciária e os diretores de área são escolhidos e nomeados pelo diretor geral. Usualmente, os diretores de área são agentes penitenciários que se destacaram em seu trabalho e são da confiança do diretor geral. É necessário ter nível superior completo para ser diretor de unidade prisional.
} 
que dificulta a apuração. Os agentes não denunciam seus colegas. Os advogados da FUNAP $^{279}$ não fazem vista grossa para irregularidades cometidas pelos ASPs.

Os ASPs seguem o princípio da legalidade em suas ações, mas ainda existe certa tolerância a abusos. Está ocorrendo uma mudança de cultura, mas ainda está longe do ideal. Certamente há ASPs que facilitam entrada de celular no presídio. Ocorre mais desrespeito aos presos nos Centros de Detenção Provisória. Nestas unidades há estrutura ainda mais deficiente do que em outras e os diretores são menos profissionais.

Os ASPs não têm condições ideais de trabalho, em especial, no que diz respeito à remuneração e ao salário percebido. Eles são desvalorizados, porém, se fossem mais valorizados seriam melhores profissionais.

Os ASPs são vítimas de xingamento e de desobediência.

No que diz respeito aos fatores emocionais, o trabalho desenvolvido pelos agentes não é muito tenso.

\subsubsection{Juiz 4}

Esta entrevista abordou elementos que dizem respeito a todas as dez categorias de análise.

De acordo com esse juiz, o ASP é a figura do Estado mais próxima ao preso.

Sobre a relação existente entre o Poder Judiciário e os agentes penitenciários, ele afirmou que os juízes não tem contato direto com o ASP. Durante as visitas de inspeção o contato é com o diretor geral e com os presos. A relação entre o Poder Judiciário e o ASP constitui-se por meio das sindicâncias de faltas graves, mais especificamente pelos depoimentos prestados pelos agentes nestes procedimentos. Os agentes são testemunhas

\footnotetext{
${ }^{279}$ FUNAP é a Fundação Prof. Dr. Manoel Pedro Pimentel. É uma fundação vinculada à Secretaria de Administração Penitenciária que tem como missão "contribuir para a inclusão social de presos e egressos, desenvolvendo seus potenciais como indivíduos, cidadãos e profissionais. Para isso, planeja, desenvolve e avalia, no âmbito Estadual, programas sociais nas áreas da assistência jurídica, da educação, da cultura, da capacitação profissional e do trabalho para as pessoas que se encontrem privadas de liberdade, contribuindo para a inclusão social dos mesmos”. Desde 1977, a FUNAP presta assistência jurídica a presos carentes de recursos financeiros para contratar um advogado particular. Atualmente, conta com 271 advogados em todo o Estado de São Paulo. Estes advogados são lotados nas unidades prisionais e realizam atendimento jurídico dos presos. Disponível em: <http://www.funap.sp.gov.br/sobre.html>. Acesso em: 21 dez. 2012.
} 
das faltas graves, apreendem celulares, drogas, e também verificam a ocorrência de danos à cela.

Eles são vítimas de desrespeito, desobediência e ameaças. Para o desempenho da profissão do ASP seria positivo que tivessem câmeras nos presídios, assim ficariam mais seguros, especialmente porque são vítimas de muitas ameaças.

A existência de facções criminosas nas unidades prisionais produz um impacto positivo para o trabalho do ASP, isso porque o líder da facção mantém "tudo em dia”, fazendo com que a unidade prisional funcione de acordo com as regras da direção. Por outro lado, é um fator de ameaça, principalmente porque a facção também está fora do presídio. Deste modo, o dia a dia é mais tranquilo, mas, ao mesmo tempo, é mais perigoso.

A superlotação dificulta muito o trabalho do agente, pois quanto mais pessoas presas, mais problemas o ASP terá que enfrentar.

O trabalho do ASP é muito tenso, é ainda mais tenso nas penitenciárias de segurança máxima. Contudo, nestas unidades, por não estarem superlotadas, a proporção entre presos e ASPs facilita o trabalho.

Os ASPs sentem medo, vivem muita tensão, e acabam se "endurecendo". O nível de estresse é muito alto. Passa a ocorrer uma naturalização dos conflitos. Além disso, levam a tensão para casa.

Quanto mais próximo se está dos presos, maior é a tensão. O diretor fica um pouco mais afastado, apesar de que o bom diretor é aquele que está presente nos raios ${ }^{280}$. O “clima”281 é ainda pior nas unidades de segurança máxima.

Para este entrevistado, a possibilidade dos agentes portarem arma em serviço traria maior risco para eles próprios, porque em um acontecimento dentro da unidade eles poderiam tornar-se vítimas de suas próprias armas.

\footnotetext{
280 "Raio” é o local dos presídios em que ficam as celas e o pátio, ou seja, é a parte da unidade em que a maioria dos presos fica por mais tempo. As celas destinadas ao seguro e ao castigo, em geral, não ficam nos raios. A ala destinada à educação, ao trabalho, ao atendimento médico, ao atendimento odontológico e ao atendimento psicológico - quando existentes - também não ficam nos raios. As unidades prisionais têm mais de um raio e o tamanho e a disposição variam em função do projeto arquitetônico.

281 “Clima” é uma expressão muito utilizada para descrever a situação nas cadeias. Diz-se, por exemplo, “o clima está calmo”, “o clima está para virar”. "Para virar” significa que está para ter uma rebelião.
} 
Quando são realizadas as visitas de inspeção pelos juízes, os ASPs ficam apreensivos porque muda a rotina, a dinâmica e a organização. É necessário que realizem a “tranca” dos presos em outro horário, por exemplo.

O diretor é o corregedor do ASP, "está de olho" em suas atitudes. O ASP facilita a entrada de celular e de drogas, mas os juízes não ficam sabendo qual ASP especificamente adotou tal conduta ilegal.

O valor da palavra do ASP em um procedimento de falta grave é semelhante ao que a Polícia Militar tem no processo criminal de conhecimento. Em regra, dá-se crédito à fala do ASP, porém, quando o ASP não sabe o que aconteceu (aproximadamente em metade dos casos), não se pode utilizar apenas o seu depoimento para decidir.

\subsubsection{Juiz 5}

O conteúdo colhido nesta entrevista encaixou-se em todas as categorias de análise.

A maior parte dos ASPs é séria, desenvolve seu trabalho com seriedade. O ASP está em contato com a divergência que surge no calor do momento, está lá diariamente, sendo a "linha de frente”. São responsáveis por fazer a intermediação entre os presos e o diretor. O ASP tem uma boa visão do que acontece no presídio e possui informações importantes para que o juiz fique a par da realidade daquela unidade. Trabalham com questões muito delicadas, em atividades de grande risco. A facção também produz impacto no trabalho do ASP e por isso em cada unidade é diferente, pois depende da facção e do perfil dos presos que ali se encontram.

Garantir que não haja rebeliões é um dos principais objetivos dos ASPs. Contudo, também participam do processo de reintegração social dos presos, em especial no regime semiaberto.

O contato entre os agentes e o Poder Judiciário é rotineiro: o ASP leva procedimentos e notícias de falta grave para o juiz e também estabelecem contato durante as visitas de inspeção.

A relação que é estabelecida entre o Poder Judiciário e os agentes é de respeito e confiança. Estabelecer contato com os agentes penitenciários permite ao juiz ter uma visão 
geral do que acontece no presídio, uma vez que o juiz não está lá todos os dias. Tal contato é importante para entender as dificuldades do presídio, a situação do "clima" da unidade.

Nos procedimentos de falta grave e denúncias sobre a conduta dos ASPs, a análise deve ser cuidadosa por parte do Poder Judiciário, porque no cotidiano existem divergências e desgastes. Quando os ASPs são testemunhas, as faltas graves são analisadas com cuidado.

Para serem compreendidos pelos presos, respeitados e conquistarem a confiança deles, os ASPs utilizam linguagem diferenciada, de gírias. Porém tomam cuidado com a linguagem que utilizam em casa, porque no trabalho utilizam gírias próprias do sistema prisional.

A relação entre os agentes e os presos é de troca e de confiança. A visão do ASP ajuda a conseguir benefícios para a população carcerária (ex.: contrato com o Clube Corinthians para presos trabalharem nas obras do estádio teve importante papel dos $\mathrm{ASPs}^{282}$ ). Os ASPs não são inimigos dos presos, além da disciplina e da segurança, também fazem conscientização. Um exemplo do trabalho de conscientização é o que realizam na época da saída temporária, em que abordam a necessidade de retorno à prisão na data estipulada e de cumprimento das regras para que possam obter benefícios mais amplos.

Os ASPs são parceiros do diretor. Mas os diretores "estão de olho" na corrupção cometida pelos agentes. Existem ASPs corruptos e estes casos são apurados pela corregedoria. A maioria não é corrupta, pois a estrutura busca retirar os corruptos do sistema.

A palavra do servidor público tem peso grande nos processos judiciais. A oposição que existe entre a palavra do ASP e do preso é semelhante a do policial militar e do réu no processo de conhecimento. A palavra do ASP tem grande valor, mas a confiança não é cega.

\footnotetext{
282 Presos vão ser contratados para trabalhar no Corinthians. G1. 2 abr. 2012. Disponível em: <http://g1.globo.com/sao-paulo/noticia/2012/04/presos-vao-ser-contratados-para-trabalhar-nocorinthians.html>. Acesso em: 09 dez. 2012. EX-DETENTOS erguerão o estádio do Itaquerão. Folha de São Paulo, São Paulo, 5 ago. 2011. Disponível em: <http://www1.folha.uol.com.br/esporte/954932-ex-detentoserguerao-o-estadio-do-itaquerao.shtml>. Acesso em: 9 dez. 2012. CONSTRUTORA vai empregar detentos em obras do estádio do Corinthians. Globo Esporte, São Paulo, 30 jan. 2012. Disponível em: $<$ http://globoesporte.globo.com/futebol/copa-do-mundo/noticia/2012/01/construtora-vai-empregar-detentosem-obras-do-estadio-do-corinthians.html>. Acesso em: 9 dez. 2012.
} 
Os ASPs precisam de respaldo, precisam ser respaldados em sua atividade profissional. Respeitar o ASP é fundamental, por isso é importante que o juiz valorize a palavra do agente no processo. O trabalho que os agentes desenvolvem é muito insalubre, sendo que alguns já foram reféns em motins; o dia a dia é muito tenso e sentem medo por estarem muito expostos.

\subsubsection{Juiz 6}

Este entrevistado referiu-se às temáticas pertinentes a todas as categorias.

Segundo ele, os agentes penitenciários são "a linha de frente do sistema prisional”, já que estão em contato direto com os presos. São fundamentais para manutenção do sistema prisional, ajudam a conter o sistema. Evitam, inclusive, rebeliões ao conversarem com os presos. Os agentes ajudam os presos; fazem a ponte entre o preso e a direção da unidade.

Os ASPs têm uma rotina de trabalho estabelecida, cada um trabalha em um setor, têm procedimentos de segurança a realizar.

A escola de formação do ASP fornece preparação psicológica.

Alguns ASPs são vocacionados.

O Poder Judiciário não tem muito contato com o ASP, os juízes falam pouco com eles nas visitas de inspeção, sendo que o contato é mais intenso com o diretor da unidade. O agente que trabalha no interior do Estado é mais próximo do Poder Judiciário do que aqueles que trabalham na capital. No interior do Estado, o diretor conhece todos os ASPs e sabe onde moram, já na capital a relação é mais impessoal.

O Poder Judiciário deve interferir o mínimo possível na parte administrativa das prisões, deve dar apoio para conter a disciplina na unidade, por isso deve julgar com rigor as faltas graves, sendo que, apenas excepcionalmente, deve desconsiderá-las. É dada uma força grande à palavra do ASP, exatamente por ser preciso respaldar o ASP, é necessário presumir sua boa-fé no desempenho da função e no processo disciplinar.

Os agentes são vítimas de indisciplinas, como ofensa verbal (que também ocorrem contra outros presos) e desacato. Ocorrem mais casos do que são levados ao conhecimento 
do Poder Judiciário. Muitos destemperos e verbalizações desrespeitosas acabam não sendo registradas oficialmente.

Comumente os agentes são testemunhas de faltas graves como: porte de celular e de droga, fuga e dano ao patrimônio.

O trabalho é de risco constante, o clima é muito tenso nas penitenciárias. Todos os agentes sentem medo. Nas unidades em que os agentes não têm contato direto com os presos, a segurança do funcionário é maior. A prisão é um depósito de gente, o que também é negativo para os ASPs, pois a pessoa desocupada tem tempo para pensar "besteira".

O ASP corre maior risco em função da presença de facções criminosas no interior das unidades, pois a facção corrompe os funcionários e, ao mesmo tempo, oprime os presos. A Polícia Militar e os ASPs lutam contra as facções.

O número de profissionais é reduzido para realizar todo o trabalho necessário. Por isso o ASP que tira muita licença ou falta muito dá mais trabalho do que os próprios presos.

Existe corrupção por parte dos agentes, a facção corrompe os funcionários. Por outro lado, atos de violência praticados por ASPs são apenas fatos isolados. Por isso, os presos não reclamam para os juízes durante as visitas de inspeção e nem pelos familiares. Provavelmente, tortura não ocorre, há um ou outro destempero.

\subsubsection{Juiz 7}

Esta entrevista apresentou conteúdo que se encaixa em oito categorias de análise. As categorias que não contaram com conteúdos expressados por este entrevistado foram a categoria 6: Vulnerabilidade e segurança do ASP no exercício da sua profissão e a categoria 10: Impacto da existência do crime organizado na atuação do ASP.

De acordo com o que foi dito por este juiz, a grande maioria dos agentes é formada por bons profissionais. Eles realizam o curso da Secretaria de Administração Penitenciária e treinamento com outros ASPs antes de serem designados para a função propriamente dita. 
Os agentes possuem contato direto com os presos. Eles precisam assegurar que os presos cumpram as regras da execução penal. Além disso, são responsáveis por preservar a integridade física, entendida como saúde e direitos dos presos. Somado a estas duas tarefas ainda desenvolvem atividades administrativas e burocráticas.

Os agentes realizam apreensão de drogas, celulares, manuscritos da contabilidade do crime e também têm o papel de evitar e de testemunhar fugas. Por outro lado, são vítimas de desacato, desobediência e xingamentos.

A relação entre os agentes e o diretor da unidade é respeitosa e tranquila, sendo que os ASPs reportam os problemas que vivenciam ou que verificam para o diretor que, por sua vez, reporta ao Poder Judiciário.

O contato pessoal entre os juízes e os agentes é pequeno. Dá-se quando os ASPs acompanham os presos para as audiências. Os agentes mandam e-mails para a Vara de Execuções Criminais e o juiz dá encaminhamento às demandas.

Nas visitas de inspeção nos presídios, os ASPs não conversam com os juízes. Os ASPs procuram o Ministério Público para denunciar as irregularidades que presenciam e este órgão fica responsável por judicializar as questões.

A grande maioria é formada por bons profissionais, mas há aqueles que se envolvem com a criminalidade, segundo o entrevistado, talvez por estarem em contato direto com criminosos. Algumas agentes femininas envolvem-se amorosamente com os $\operatorname{presos}^{283}$.

Ocorrem casos de corrupção e de agressões físicas cometidas por agentes. Nestes casos, é instaurado procedimento disciplinar. Se alguns casos são abafados, o entrevistado não sabe dizer. Chegam poucos fatos mais sérios cometidos por ASPs para apreciação do Poder Judiciário e os casos que chegam não levam à autoria por falta de provas, e são, em geral, denúncias anônimas, o que dificulta, ainda mais, a apuração dos fatos.

A relação que se estabelece entre os agentes e o Poder Judiciário é de respeito e educação. Mas existe uma percepção por parte dos ASPs de que o juiz “pode tudo” e está “acima de tudo”, então alguns agentes fazem demandas que não estão na esfera de atuação dos juízes e ficam frustrados com o fato de não serem atendidos.

\footnotetext{
${ }^{283}$ Essa observação foi feita de forma pejorativa.
} 
A valorização da palavra do ASP nos processos judiciais é idêntica a de qualquer outro agente público, presume-se que o ASP está falando a verdade. É prestigiada a palavra do ASP em detrimento da palavra do preso. Cabe ao preso provar que não foi aquilo que aconteceu.

Os agentes têm grande sobrecarga de trabalho com a superlotação das unidades prisionais, que em geral estão 100\% acima da capacidade. O número de servidores contratados para trabalhar na unidade é baseado na capacidade máxima prevista para cada unidade.

O trabalho dos agentes é muito estressante, eles estão em contato direto com os criminosos, com os condenados. Por este motivo, alguns ASPs desenvolvem, inclusive, problemas emocionais.

\subsubsection{Juiz 8}

Esta entrevista deixou de abordar elementos que dissessem respeito a apenas uma das categorias: categoria 6: Vulnerabilidade e segurança do ASP no exercício da sua profissão.

A carreira de agente penitenciário é semelhante à carreira de qualquer outro agente público: existem os profissionais que fazem um trabalho excepcional, mas há outros que não cumprem o papel e agem de maneira arbitrária; há os excelentes, os médios e os ruins; existem os bons e os maus profissionais. Os maus profissionais são arbitrários, pois sabem que têm um poder muito grande dentro da prisão.

O ASP recebe a função de exercer uma atividade que envolve as pessoas que são tidas pela sociedade como as piores, são profissionais que trabalham com estas pessoas. Neste sentido, os ASPs foram doutrinados pelo próprio sistema para ter uma visão e uma filosofia disciplinar. A disciplina é uma das funções do ASP.

Existe um conflito entre a disciplina de um lado e a visão humanitária, de direitos humanos e de ressocialização, de outro. Não se pode ofender direitos em nome da disciplina, mas muitos ASPs entendem que o valor “disciplina” deve ser sobreposto. A disciplina é semelhante à arbitrariedade, ela naturaliza, normaliza e valida, por meio da repetição, atos violadores de direitos. 
Os agentes veem os juízes como profissionais que não conhecem a realidade carcerária e, por vezes, o ASP está certo nesta avaliação. Neste sentido, o ASP vê o Poder Judiciário com desconfiança.

Os ASPs e os presos usam uma linguagem homogênea, um código que só eles compreendem (ex.: "bonde" ${ }^{284}$, "pote" ${ }^{285}$ ). Às vezes, o ASP leva essa linguagem para casa.

Atualmente tem-se maior respeito no chamamento do preso do que antigamente, evita-se chamar o preso de "ladrão" 286.

Relação do ASP com o preso é de troca, sendo que o ASP capta coisas do preso e vice-versa. Os agentes e os presos são, em geral, da mesma classe social. Neste sentido, a prisão é um retrato homogêneo no aspecto da classe e da origem social.

De acordo com o entrevistado, a prisão foi feita para miseráveis e são pobres que trabalham com esses miseráveis. A relação de poder dentro das prisões é muito grande e pode ser usada de forma positiva ou negativa. A forma negativa pode levar à corrupção. Um exemplo de poder exercido pelo ASP é com relação à punição, em âmbito administrativo, decorrente de falta grave. Em geral, as punições aplicadas pelos ASPs são mantidas administrativamente ${ }^{287}$. O diretor não a “cancela” e não a apura, para não desmoralizar o ASP: em nome da disciplina considera melhor manter a falta em vez de verificar o ocorrido.

O poder dentro da prisão é potencializado. O ASP, na relação de poder, pratica atos arbitrários, como, por exemplo, aplica falta grave em casos em que estas não ocorreram, para prejudicar um preso, pratica violência sem deixar marcas - mas, caso aconteça de forma a deixar marcas, alega que foi o preso quem "partiu pra cima".

Os outros ASPs não denunciam porque têm medo de represálias. Mesmo estando em número inferior aos presos, os ASPs conseguem exercer o poder ao gerar situações em que estejam presentes mais agentes do que presos.

\footnotetext{
284 "Bonde” é o transporte do preso, seja para ir a uma audiência, para ser levado a um atendimento médico hospitalar fora da unidade prisional ou para ser transferido de presídio.

285 "Pote" é a cela utilizada para o castigo dos presos. Neste lugar os presos ficam em solitária e as condições desta cela são sempre as piores no que diz respeito à limpeza, ao saneamento, à iluminação e à aeração. Em geral, estas celas ficam na parte mais distante da entrada da cadeia, no chamado "fundão".

${ }^{286}$ Esse "chamamento" era utilizado para todo e qualquer preso, ou seja, os agentes penitenciários chamavam todos os presos de "ladrão".

${ }^{287}$ O procedimento de justificação de falta grave está previsto no art. 118, §2 ${ }^{\circ}$ da LEP. O procedimento judicial é uma espécie de oportunidade de justificação, onde, mesmo a falta grave tendo ocorrido, o juiz pode decidir que não resulte em consequências ainda maiores para o preso, como a regressão de regime e a perda dos dias remidos.
} 
O diretor às vezes silencia sobre atos de corrupção praticados pelos ASPs por medo de represálias. Ele também é pressionado pelos funcionários. O diretor "humanista” é mal visto, pois está protegendo o “ladrão”. Ele está na corda bamba e sofre pressão da política da “velha guarda” que não é nada humanista.

Existem ASPs muito bons, que adoram o que fazem, vibrando com seu trabalho, atuam sem arbitrariedades e com respeito. O ASP corrupto fica logo conhecido e perde o respeito que os outros ASPs nutriam por ele. Alguns desrespeitam os direitos dos presos por "ruindade”. O Estado não entra na prisão, o ASP está escondido da sociedade dentro do presídio, o que facilita que cometam ilegalidades e prática de abusos.

Sobre a valorização da palavra do agente público nos processos, a fé pública não é absoluta no campo dos direitos fundamentais. Não se pode considerar tudo como verdade, para não se correr o risco de chegar a um regime totalitário, como foi o nazismo.

O ambiente de trabalho do ASP é muito carregado. Em alguns casos, ele leva valores daquele ambiente. O ambiente é muito forte, deixa as pessoas, que entram em contato, impregnadas do "ar carcerário". Ao olhar da sociedade, as piores pessoas da sociedade estão na prisão, o que não é verdade. O sistema de trabalho do agente é muito complexo.

Com a organização dos presos, as agressões cometidas por ASPs aos presos diminuíram, passou a ser necessário “ter mais cuidado para agredi-los”. Ao se organizarem, os presos adquiriram mais consciência de seus direitos e começaram a lutar por eles, às vezes de modo ilícito e ilegítimo. A população carcerária é heterogênea e tem presos que não fazem parte de nenhuma organização criminosa, esses são mais subjugados pelos demais presos e pelos ASPs.

\subsection{Leitura Horizontal}

São dez as categorias de análise criadas nesta pesquisa ${ }^{288}$. O conteúdo das entrevistas foi enquadrado em tais categorias, de modo que todas elas foram preenchidas com trechos de ao menos cinco entrevistados, sendo que quatro destas categorias foram abordadas por todos os juízes. Isto permitiu uma análise mais abrangente de cada

\footnotetext{
${ }^{288}$ Sobre a metodologia adotada para criar as categorias, vide supra capítulo 3.
} 
categoria, já que a pesquisa não se sustenta em apenas uma entrevista. Passa-se, agora, à apresentação e à análise dos dados pertinentes às categorias.

\subsubsection{Categoria 1: Preparo, papel e formas de atuação do ASP}

Aqui foram incluídas as falas que dizem respeito à formação dos agentes penitenciários, aos requisitos necessários para ser ASP, ao papel do agente na execução penal e na condução do dia a dia carcerário, às funções que exercem e de que forma o fazem. Todos os entrevistados abordaram pelo menos um desses temas ao longo da entrevista.

A metade dos entrevistados focalizou o preparo que os ASPs recebem para exercer a profissão ou falou sobre o preparo que seria necessário que recebessem.

Dois falaram sobre as lacunas na preparação destes profissionais. Um deles disse não saber os requisitos exigidos para ingressar na carreira de agentes penitenciários, mas destacou que no Estado do Rio de Janeiro é necessário que se tenha nível superior. Para ele, falta preparo intelectual aos ASPs para que possam atender aos objetivos da execução penal. Por exemplo, deveriam ser capacitados em primeiros socorros, psicologia, pedagogia e idiomas - importante para atender presos estrangeiros - mas não são.

Para outro entrevistado os ASPs não recebem preparo sociológico, o que considera uma falha.

Dois falaram sobre os aspectos positivos da etapa de preparação. Segundo um deles, a Escola de Formação destinada aos ASPs fornece preparação psicológica. E, de acordo com outro entrevistado, eles realizam um curso preparatório na SAP, depois treinamento com outros ASPs e só depois de cumprirem essas duas etapas são designados para a função.

Vê-se que o tema do preparo intelectual, formal e teórico ganha bastante destaque na percepção do Poder Judiciário. Os juízes reconhecem que existe algum preparo, porém que este é insuficiente para que o ASP possa cumprir com a sua função, considerada importante pelos magistrados. 
Muitos dos entrevistados salientaram que o agente penitenciário é o funcionário público que está em contato direto e permanente com os presos. São a "linha de frente" do sistema prisional e são "o elo de ligação” (sic) entre o Estado e os presos, entre a administração e direção da unidade e os presos. Para um destes entrevistados, os agentes têm a função de exercer um papel que envolve as pessoas que são tidas pela sociedade como as piores, são profissionais que trabalham diretamente com essas pessoas. Outro destacou o fato do agente ser "a primeira trincheira” que o sentenciado tem ao ingressar no sistema prisional.

Três entrevistados destacaram que os ASPs são fundamentais para a execução penal e têm dois objetivos principais: (i) orientação e acompanhamento na ressocialização; (ii) monitoramento da disciplina e das normas. Um dos entrevistados definiu o ASP como o parceiro do Estado no objetivo da recuperação dos presos, sendo que considera esse o objetivo principal da execução penal. Portanto, não são carcereiros e nem guardas de presídios, como antigamente - tais termos, hoje, são considerados impróprios. Simultaneamente, são fiscalizadores. Eles devem fiscalizar, monitorar e auxiliar os presos.

Outro entrevistado destacou que a atuação do ASP é muito importante no dia a dia da vida prisional e que eles têm altíssima relevância para a ressocialização, uma vez que são responsáveis por tal processo e pelo aspecto disciplinar. Cabe ao ASP identificar problemas de disciplina e de grupos.

Outro juiz destacou que garantir que não haja rebeliões é um dos principais objetivos dos ASPs, ao mesmo tempo em que participam da reintegração social dos presos - especialmente no regime semiaberto. No mesmo sentido, outro entrevistado disse que os ASPs ajudam a conter o sistema e são fundamentais para manutenção deste, pois evitam rebeliões conversando com os presos.

Para outro, os agentes são responsáveis por preservar a integridade física - a saúde - e os direitos dos presos, ao passo que eles têm que fazer com que sejam cumpridas as regras da execução penal. Alguns, ainda, são responsáveis por desenvolver tarefas administrativo-burocráticas. De acordo com outra entrevista, os agentes estão em contato com as divergências que surgem no calor do momento.

Um dos entrevistados expressou uma percepção diversa dos demais, afirmando que os ASPs foram doutrinados pelo próprio sistema para ter uma visão e uma filosofia disciplinar. A disciplina é uma das funções do ASP, mas existe um conflito entre a 
disciplina e a visão humanitária, de direitos humanos e ressocialização. Segundo o entrevistado, não se pode ofender direitos em nome da disciplina, mas muitos ASPs entendem que o valor da disciplina deve sobrepor-se aos demais. A disciplina é semelhante à arbitrariedade: ela naturaliza, normaliza e valida pela repetição atos violadores de direitos.

A função principal do agente penitenciário é bastante discutida pelos entrevistados, sendo que eles percebem a função ressocializadora como mais importante e como sendo o objetivo dos ASPs, colocando a função disciplinar como relevante, mas não como principal.

Um dos entrevistados disse que os agentes têm uma boa visão do que acontece no presídio e possuem informações importantes para que o juiz fique a par da realidade da unidade prisional.

Dois entrevistados deram destaque ao fato do ASP ser responsável pelo funcionamento completo do presídio, por serem responsáveis por realizar todas as tarefas: auxiliar técnicos, “tranca”, "banho de sol”, escoltas para audiência e para hospitais. Para outro juiz, os agentes têm uma rotina de trabalho definida, cada um trabalha em um setor e executam procedimentos de segurança.

De maneira geral, os juízes depositam nos agentes penitenciários a responsabilidade pela manutenção da prisão, ou seja, percebem estes profissionais como sendo os principais responsáveis por assegurar que a prisão exista e se mantenha sob a tutela do Estado e não seja "governada” pelos presos.

Quatro juízes citaram como parte rotineira da atividade profissional do agente o testemunho das faltas cometidas pelos presos. "São as principais testemunhas do que ocorre no presídio”, disse um dos quatro juízes. Os outros três disseram que os agentes são testemunhas da posse de drogas e celulares pelos presos.

Dois juízes disseram que os agentes testemunham fugas e tentativas de fuga. Um disse que também são testemunhas de dano ao patrimônio e outro que os ASPs apreendem manuscritos da contabilidade do crime. Um juiz disse que apreender armas é raro.

A tarefa de testemunhar faltas cometidas pelos presos aparece com bastante relevo nas entrevistas. O Poder Judiciário percebe essa função como fundamental e também como rotineira para os ASPs. Como era de se esperar, tal função foi destacada pelos 
entrevistados, uma vez que a faltas testemunhadas por agentes geram procedimentos formais que chegam ao conhecimento do juiz da execução. Eles são os responsáveis legais por dar a última palavra, ou seja, por manter ou cancelar a falta e decidir sobre as consequências daquela falta para o seu autor, por exemplo, a perda dos dias remidos. Sendo assim, os juízes têm muito contato com este tipo de procedimento e é uma das formas de conhecer o que se passa nos presídios e mais sobre o universo profissional do ASP.

Para três entrevistados, a maioria dos ASPs é formada por bons profissionais, sérios e “melhores do que se pode imaginar”. Dois ressaltaram que alguns são vocacionados para a profissão.

Para um dos juízes, o ASP é agente público como qualquer outro, há aqueles que fazem um trabalho excepcional, mas também aqueles que não cumprem o seu papel e agem de maneira arbitrária. Há os excelentes, os médios e os ruins. Existem os bons e os maus profissionais; os maus profissionais são arbitrários, e utilizam-se do grande poder que sabem ter dentro da prisão.

Neste momento, os juízes estão externando seus conceitos e suas pressuposições sobre os agentes penitenciários, mas também deixam transparecer como compreendem a percepção que os outros têm sobre os agentes. Ao afirmar que "são melhores do que se pode imaginar”, o entrevistado acredita que a sociedade imagine que eles são piores do que realmente são. Mas, além disso, os juízes demonstraram que valorizam o agente penitenciário e que os enxergam como sendo bons profissionais e vocacionados. Houve uma divergência neste ponto, quando um dos entrevistados colocou os ASPs no mesmo nível dos demais agentes públicos e ponderou que existem os bons e os maus profissionais.

\subsubsection{Categoria 2: Relacionamento entre os ASPs e o Poder Judiciário}

Esta categoria abordou os elementos que dizem respeito à relação estabelecida entre os agentes penitenciários e o Poder Judiciário, representado pela figura dos juízes.

As oito entrevistas trataram de aspectos relativos a essa categoria de análise.

A maioria dos entrevistados relatou ser reduzido o contato pessoal entre o juiz e o ASP. O contato que o Poder Judiciário estabelece com os ASPs é através dos processos e 
procedimentos judiciais, em especial a partir dos depoimentos que os agentes prestam nestas situações. Nas visitas de inspeção mensais, os juízes travam mais contato com o diretor da unidade e com os presos do que com os agentes. Um dos juízes manifestou posicionamento diverso e afirmou que o contato pessoal é rotineiro e dá-se quando os ASPs levam procedimentos e notícias dos cometimentos de faltas graves para o juiz e também durante as visitas de inspeção.

Dois entrevistados relataram que os agentes penitenciários recebem os juízes muito bem nas visitas de inspeção; um juiz acrescentou que isso se deve ao fato de ser tarefa deste verificar a regularidade do presídio e não fiscalizar a conduta dos agentes.

Para outro juiz, o ASP fica apreensivo nas visitas de inspeção, pois elas alteram a rotina, a dinâmica e a organização. Por exemplo, é necessário trancar os presos nas celas para que o juiz possa inspecionar a unidade.

Para outro entrevistado, a inspeção mensal é muito importante para conhecer a rotina e a pressão vividas pelos ASP.

Outro entrevistado acrescentou que o contato entre o Poder Judiciário e o ASP permite que o juiz tenha uma visão geral do que acontece no presídio, porque ele não está lá todos os dias, ao passo que os ASPs, $\operatorname{sim}^{289}$. Tal contato é importante para que o juiz possa entender as dificuldades do presídio e conhecer o “clima” da unidade.

De acordo com um dos entrevistados, o ASP que trabalha no interior do Estado é mais próximo do Poder Judiciário do que aqueles que trabalham na capital.

Neste ponto vale destacar a convergência da maioria dos posicionamentos sobre o pouco contato pessoal existente entre os agentes penitenciários e os representantes do Poder Judiciário. Esta é, de certo modo, uma surpresa, pois a opção metodológica por entrevistar juízes da execução deu-se justamente por serem os juízes da Vara das Execuções Criminais mais próximos do sistema penitenciário e, supostamente, dos agentes.

O entrevistado que apresentou uma visão divergente neste ponto, considera importante manter relações próximas e de troca de informações com os agentes para que ambos aperfeiçoem o desempenho profissional.

\footnotetext{
${ }^{289}$ Os agentes penitenciários trabalham em regime de plantão: são 12 horas de trabalho e 36 horas de folga. Os agentes que trabalham em funções de direção ou administrativas não seguem esse mesmo regime e adotam o regime de diaristas.
} 
No que se refere, especificamente, à qualidade da relação existente entre os agentes penitenciários e o Poder Judiciário, apareceu nas entrevistas que a relação é muito boa, de respeito e de educação; não de temor hierárquico. Para um dos entrevistados, a relação é permeada por confiança.

Aparentemente, o Poder Judiciário tem uma percepção de que a relação entre os juízes e os agentes é de igualdade, ou seja, não há uma visão hierárquica da relação e nem de superioridade. Cada um exerce um papel, porém não estão no mesmo organograma, não se estabelecendo, portanto, subordinação hierárquica. A posição dos agentes está localizada na esfera administrativa, que não se confunde com a esfera do Judiciário.

De acordo com um dos juízes entrevistados, as faltas graves cometidas por presos sempre chegam ao conhecimento do Judiciário para que o procedimento legal seja seguido. Outro entrevistado afirmou que ele não tem certeza se é comunicado de todas as faltas graves que ocorrem, mas tem que supor que sim, já que o juiz deve ser inerte e só se manifestar sobre os procedimentos que são levados ao seu conhecimento.

Um dos entrevistados afirmou que o juiz deve cancelar as faltas quando a gravidade do xingamento do preso contra o ASP é pequena. Outro fez uma afirmação complementar a essa, ao dizer que as condutas devem ser analisadas com cautela, pois no cotidiano existem divergências e desgastes. Quando os ASPs figuram como testemunhas, as faltas graves são analisadas com cuidado.

Um dos entrevistados afirmou que o Poder Judiciário deve interferir o mínimo possível na parte administrativa das unidades, o papel é de apoiar a atividade disciplinar. Por esta razão, deve julgar com rigor o cometimento das faltas graves - que são atos de indisciplina e desrespeito às normas, em especial àquelas que têm os agentes como vítimas. Por esse motivo, apenas excepcionalmente o juiz deve desconsiderar uma falta grave.

Segundo um dos entrevistados, o Poder Judiciário é o receptor das denúncias e representações feitas pelos ASPs contra a direção da unidade e também daquelas feitas por presos contra os ASPs.

Para outro, o juiz não fica sabendo de tudo o que acontece no presídio. São poucos casos de irregularidade e abusos praticados por agentes que chegam ao conhecimento do juiz. Além disso, para outro entrevistado, ocorrem mais faltas graves em que os ASPs são vítimas de indisciplinas - como ofensa verbal e desacato - do que aquelas que chegam ao 
Judiciário, isso porque o destempero e as verbalizações desrespeitosas acabam não sendo registradas.

Em outra entrevista, apareceu a informação de que chegam poucos fatos mais sérios cometidos por ASPs ao conhecimento do Poder Judiciário. Segundo este juiz, os casos que chegam são de forma anônima, o que dificulta a apuração dos casos e acabam por não levar à autoria. Também é de se salientar que os agentes procuram o Ministério Público para denunciar crimes ou atitudes cometidas por seus colegas, e, assim, o órgão judicializa as questões. Alguns agentes optam por enviar e-mail para a Vara de Execução Criminal e o juiz dá o encaminhamento legal às denúncias e demandas.

Há uma reflexão sobre a fragilidade das denúncias de irregularidades cometidas pelos ASPs. O fato de serem em geral anônimas, ou não indicarem concretamente nomes e datas, impossibilita a apuração dos abusos cometidos e a responsabilização dos culpados.

Há, de certo modo, um reconhecimento da ausência de combate a essas irregularidades cometidas. Provavelmente, os denunciantes têm receios e não realizam as denúncias devido a um movimento de autoproteção e por adotarem uma postura conivente com o ato cometido. Isso enfraquece o papel do Poder Judiciário, que deveria controlar a legalidade dos atos cometidos no interior das unidades prisionais.

No que diz respeito à visão que os agentes penitenciários têm sobre o Poder Judiciário, respostas divergentes surgiram. Para um dos entrevistados, o ASP tem a mesma impressão sobre o Judiciário do que qualquer cidadão, percebe os méritos e as mazelas. Para outro, os ASPs acham que o juiz “pode tudo” e está “acima de tudo”. Já para um terceiro, o ASP vê o Judiciário com desconfiança, vê o juiz como alguém que não conhece a realidade carcerária, estando, por vezes, certo em tal avaliação.

\subsubsection{Categoria 3: Relacionamento entre os ASPs e os presos}

Essa categoria diz respeito ao relacionamento que é estabelecido entre os agentes penitenciários - na unidade prisional em que atuam - e os presos. Apenas uma das entrevistas não abordou tal assunto.

O fato dos agentes serem testemunhas das faltas cometidas pelos presos, além de usualmente serem vítimas destas faltas, apareceu na maioria das entrevistas realizadas. Foi 
destacado que os agentes são testemunhas da posse de celular e drogas, de danos à cela. Além disso, são vítimas de ameaças, agressões, desrespeito, xingamentos, indisciplinas como ofensas verbais, que também ocorrem entre os presos -, desobediência e desacato.

Para um dos entrevistados, não é comum que os ASPs forjem faltas, ou seja, não é comum que deem início ao procedimento de apuração de falta grave em casos em que os fatos não tenham ocorrido. Em muitas unidades, a relação de convivência entre presos e agentes é tranquila. Isto varia, também, em função do estabelecimento prisional e do diretor, mas a relação entre presos e ASP não é de inimigos, o agente faria o possível para ajudar os presos.

Outro entrevistado disse que os ASPs não são inimigos dos presos, que a relação entre eles é “de troca e de confiança”. Para ele, os ASPs ajudam a conseguir benefícios para a população carcerária. Por exemplo, o contrato assinado com o Clube Corinthians, quando presos passaram a trabalhar nas obras do estádio, teve importante participação dos ASPs. Os agentes, além de cuidarem da disciplina e da segurança, também fazem a conscientização dos presos, como na época de saída temporária, em que conversam com eles sobre a necessidade de voltarem para a prisão na data estabelecida e de cumprirem as regras para obterem benefícios mais amplos posteriormente.

A relação entre presos e agentes aparece nas entrevistas realizadas como sendo de parceria e não de inimizade, como se ambos estivessem interessados no mesmo objetivo, que é a ressocialização. Aqui, reforça-se um elemento presente na categoria 1, que é a valorização do ideal ressocializador frente ao ideal disciplinador.

Para que a comunicação flua, para que se façam entender, para serem respeitados e conquistarem a confiança dos presos, os ASPs utilizam linguagem diferenciada, de gírias. Esse elemento foi destacado em duas entrevistas. Os ASPs utilizam um código que só eles e os presos compreendem (ex.: “bonde”, “pote”). Às vezes, o ASP leva essa linguagem para casa.

Para este mesmo entrevistado, atualmente os agentes têm um respeito maior no chamamento do preso, evitam chama-los de “ladrão”. A relação do ASP com o preso é de troca: o ASP capta elementos do preso e vice-versa.

Acrescenta, ainda, que os agentes e os presos são, em geral, da mesma classe social, sendo a prisão um retrato homogêneo dos aspectos de classe e origem social. Segundo ele, a prisão foi feita para miseráveis e são os pobres que trabalham com os miseráveis. 
Os conflitos entre aproximação e distanciamento entre agentes e presos, e os desafios que isso impõe, estão presente nessas afirmações sobre a linguagem utilizada.

A relação de poder do agente sobre o preso dentro da unidade prisional é muito grande. Esse poder pode ser usado de forma positiva ou negativa, sendo que a forma negativa pode levar à corrupção.

\subsubsection{Categoria 4: Relacionamento entre os ASPs e a direção da unidade prisional em que trabalham}

Aqui foram incluídos os elementos que tratam da relação estabelecida entre os agentes penitenciários e a direção da unidade prisional em que estes agentes trabalham. Duas entrevistas não explicitaram conteúdos que se relacionam com este ponto da análise.

Dois juízes disseram que o diretor fiscaliza o trabalho do ASP e que está atento aos desvios que estes possam cometer, como a corrupção. Ambos utilizaram, inclusive, a mesma expressão, “o diretor está de olho no ASP”. Mas um desses juízes afirmou que os agentes são, ao mesmo tempo, parceiros do diretor.

Em outra entrevista apareceu algo similar, foi dito que a relação entre o ASP e o direto da unidade é respeitosa e tranquila. Os ASPs reportam problemas que estão vivenciando no dia a dia com os presos e outras situações específicas para o diretor que, por sua vez, reporta tais informações ao Poder Judiciário.

Contudo, em outra entrevista apareceu exatamente o contrário, que o diretor conhece tudo o que acontece na unidade, mas em geral não faz questão de apurar os abusos cometidos por ASPs, ou seja, faz “vista grossa” às ilegalidades cometidas por agentes no exercício profissional. A conduta da chefia reflete nas ações dos subordinados, sendo esta relação fluida. Não é possível afirmar se o relacionamento é de confiança, pois isso varia de cada agente e de cada diretor. Mas, nos Centros de Ressocialização a realidade é outra, e a relação entre o diretor e os agentes é de proximidade e de confiança.

Outro juiz abordou essa problemática e disse que, às vezes, o diretor silencia sobre atos de corrupção praticados pelos ASPs por medo de sofrer represálias. Ele também é pressionado pelos funcionários quando é um diretor "humanista", fica "mal visto” por estar 
protegendo o “ladrão”. O diretor também está na “corda bamba” e sofre pressão da política da “velha guarda”, que não é nada humanista.

A questão sobre a vigilância exercida pelo diretor da unidade sobre as ilegalidades e abusos praticados por agentes é o ponto principal desta categoria. Os entrevistados valorizam a importância deste papel do diretor, mas discutem a sua aplicação concreta. As entrevistas revelaram discordância entre os juízes se os diretores realmente exercem esse importante papel ou se negligenciam tal atuação.

Para outro juiz entrevistado, no interior do Estado o diretor conhece todos os ASPs, sabe onde moram, ao passo que, na capital, a relação entre eles é mais impessoal.

Um dos entrevistados afirmou que os diretores acabam concedendo muito poder aos ASPs, por exemplo, acabam optando por não cancelar e não apurar uma falta grave reportada por um agente para não desmoralizar o ASP perante o preso. Em nome da manutenção da disciplina, considera melhor manter mesmo sem realizar a apuração, como exigem as normas. Sendo assim, as faltas graves são, em geral, mantidas administrativamente, o que já é suficiente para gerar punições para os presos. Essa postura adotada pelo diretor aumenta o poder que o ASP exerce sobre os presos.

Assim, notou-se que a questão sobre o poder exercido pelos ASPs, no interior das unidades prisionais, apareceu novamente nesta categoria.

\subsubsection{Categoria 5: Probidade dos ASPs}

Esta categoria incluiu os elementos que surgiram nas entrevistas e que se relacionam com a honestidade, com o abuso no exercício profissional, com a corrupção e com a violência praticada por agentes penitenciários. Apenas uma das entrevistas não abordou a questão da probidade.

Todos os entrevistados disseram que existe corrupção e abusos praticados pelos ASPs.

Para um dos entrevistados, existe uma minoria que é corrupta ou que comete desvios no desempenho da função, mas, para ele, não se pode estigmatizar o servidor penitenciário por causa desta minoria. 
Para outro entrevistado, existem agentes corruptos, que são os casos que a própria Corregedoria apura; mas a maioria não é corrupta, pois a estrutura busca retirar os corruptos do sistema.

De acordo com outro entrevistado, a existência de corrupção e a violência dependem da penitenciária, pois a chefia reflete nas ações dos subordinados. Algumas têm maior tolerância à prática de abusos - violência e corrupção - por parte dos ASPs. O entrevistado traçou um paralelo entre a carreira de agentes penitenciário e a carreira do policial civil. Para ele, a carreira do policial civil tem cultura de tolerância a abusos maior do que a carreira de agente penitenciário.

Os agentes seguem o princípio da legalidade, mas ainda têm certa tolerância a abusos, como, por exemplo, o fato de que certamente há ASPs que facilitam a entrada de celulares nos presídios. Ele aponta que está ocorrendo uma mudança de cultura, mas ainda está longe do ideal.

Ademais, raramente os presos denunciam os agentes e, quando o fazem, não identificam nomes ou datas, o que dificulta a apuração dos fatos, já que os próprios colegas não denunciam. Advogados da FUNAP não fazem vista grossa para irregularidades cometidas pelos ASPs: são, ao contrário, bastante combativos na defesa dos direitos dos presos.

Outro entrevistado apontou o mesmo problema, de que o ASP facilita a entrada de celulares e de drogas nas unidades, mas o juiz não fica sabendo qual dos agentes atua dessa forma, assim não se chega à autoria.

Dois outros entrevistados fazem uma análise das razões da existência de corrupção por parte dos agentes. Para um deles, a facção criminosa corrompe o funcionário. Para o outro, a grande maioria dos funcionários é formada por bons ASPs, mas há aqueles que se envolvem com a criminalidade, talvez por estarem em contato direto com os criminosos. Algumas agentes femininas se envolvem amorosamente com os presos. Para todos os casos de corrupção e agressão física, é instaurado procedimento, mas pode ser que alguns casos sejam abafados.

Para o entrevistado que atribui a existência de corrupção às ações das facções criminosas, a violência praticada por agentes são casos isolados. Os presos não reclamam para os juízes nas visitas de inspeção e nem via familiares. A tortura provavelmente não ocorre: haveria um ou outro “destempero”, mas não a prática de tortura. 
Para outro juiz, o poder dentro da prisão é potencializado: o ASP, na relação de poder com o preso, pratica atos arbitrários, como, por exemplo, instaurar procedimentos de faltas graves que não ocorreram para prejudicar o preso, pratica violência sem deixar marcas - mas, se marcas forem deixadas, alegará que foi o preso quem "partiu pra cima". Os outros ASPs não denunciam porque têm medo de sofrer represálias.

Mesmo estando em número inferior aos presos, conseguem exercer o poder ao gerar situações em que estejam em superioridade numérica. Existem ASPs muito bons, que adoram o que fazem e vibram com seu trabalho, atuam sem arbitrariedades e com respeito. O ASP corrupto fica logo conhecido e perde o respeito que os outros agentes nutrem por ele. Alguns agentes desrespeitam os direitos dos presos por “ruindade”. O Estado não entra na prisão, o ASP está escondido da sociedade lá dentro, o que gera uma situação mais favorável à prática de ilegalidades.

Questões como poder, conivência, receio em denunciar e dificuldade de apuração das faltas aparecem com ênfase nas entrevistas quando o tema é probidade do agente penitenciário. Para alguns juízes, o problema de corrupção ou a prática de violência não é comum e está associada a uma minoria de ASPs.

\subsubsection{Categoria 6: Vulnerabilidade e segurança do ASP no exercício da sua} profissão

Este item abordou as questões relativas aos fatores de segurança que envolvem o exercício profissional do agente penitenciário e os fatores que deixam-no em situação de vulnerabilidade. Dois entrevistados não discorreram sobre elementos que se incluíam deste tópico.

Todos os entrevistados que abordaram conteúdos relacionados a esta categoria relataram que o trabalho dos agentes é permeado por inseguranças e fatores que os deixam em situações de vulnerabilidade.

Um dos entrevistados disse que as condições prisionais são negativas para agentes e presos ao mesmo tempo. Os funcionários, porque ficam expostos à violência, e os presos, por conta da superlotação. Falou, também, que há um alto grau de risco para o ASP e para sua família. 
Em outra entrevista, o que se destacou foi o fato do ASP trabalhar com questões muito delicadas em atividade de grande risco. Contudo, de acordo com este juiz, cada unidade é diferente por conta das facções e do perfil dos presos que ali estão custodiados.

Outro juiz disse que o trabalho do ASP é caracterizado pelo risco constante. O clima é muito tenso na penitenciária. Destacou que nas unidades em que o agente não tem contato com os presos, a segurança é maior para eles. A prisão seria um depósito de gente, o que também é negativo para os ASPs, pois a pessoa desocupada tem tempo para pensar “besteira”. É interessante destacar que nesta entrevista foi dito que o ASP corre maior risco em função da presença da facção criminosa.

Outro juiz fez uma análise bastante interessante sobre a correlação existente entre a presença da facção e a insegurança dos agentes. Para ele, a facção impacta para o bem, pois o líder da facção criminosa mantém “tudo em dia”, ou seja, faz com que as regras disciplinares sejam todas cumpridas pelos presos. Porém, por outro lado, é um fator de ameaça, principalmente porque a facção também atua fora do presídio. Então, se por um lado o dia a dia profissional é mais tranquilo, por outro, é mais perigoso.

O fato dos agentes serem vítimas de ameaças, xingamentos e desobediências apareceu em duas entrevistas como fatores que aumentam a vulnerabilidade e a insegurança no trabalho. Para um destes juízes, seria bom para o ASP se houvesse câmeras de vigilância instaladas nos presídios, o que aumentaria a segurança deles.

Outra entrevista destacou o problema dos agentes estarem submetidos ao risco de contaminação por doenças, à situações de violência e de práticas de crime.

Dois entrevistados colocaram-se contrariamente à possibilidade dos agentes penitenciários portarem arma de fogo em serviço no interior das unidades prisionais.

Dentre os principais fatores destacados pelos entrevistados como risco para agentes penitenciários, estão a presença das facções criminosas, as superlotações e as questões decorrentes de tal situação, como maior vulnerabilidade à contaminação por doenças e à violência empregada durante as rebeliões.

A questão das facções criminosas será mais detidamente analisada na categoria 10, que foi dedicada a explorar o impacto do crime organizado no desempenho profissional do ASP. Porém, na presente categoria, a facção aparece como fator que eleva o risco das atividades dos agentes, uma vez que se estabelece uma competição pelo poder e, também, 
em função da organização dos presos, podem ser criadas situações de violência ou de rebeliões, o que atentaria contra a integridade física dos ASPs. As ameaças que os agentes recebem cotidianamente aumenta o medo de que algo seja feito contra eles.

\subsubsection{Categoria 7: Valorização, por parte do Poder Judiciário, do depoimento} do ASP

Aqui foram alocados os trechos das entrevistas que dizem respeito à maneira que o Poder Judiciário valoriza o depoimento prestado pelos agentes penitenciários nos procedimentos disciplinares contra os presos que, em geral, refere-se à apuração do cometimento de falta grave. Em apenas uma das entrevistas não estavam presentes elementos para a composição desta categoria.

Três entrevistados afirmaram que a presunção de veracidade do depoimento do ASP é relativa. Um dos juízes afirmou que não há diferença no valor dado à palavra do ASP, ou de qualquer outro agente público, em relação a qualquer outro depoente.

Outro disse que a fé pública é relativa, de acordo com a jurisprudência do Tribunal de Justiça de São Paulo, onde cada caso deve ser analisado individualmente. Para o terceiro juiz, que também afirmou ser relativa a presunção de veracidade, a fé pública não pode ser absoluta no campo dos direitos fundamentais, não se podendo considerar tudo como verdade, para não correr o risco de se estabelecer um regime totalitário, como foi o nazismo.

Para dois outros entrevistados, o valor da palavra do agente penitenciário em um processo é muito grande. Para um deles, isso se deve ao fato de ser necessário respaldar o ASP, dando apoio a seu trabalho, e por isso é essencial presumir sua boa-fé no processo. Para o outro, a presunção de que o ASP diz é verdade decorre da sua condição de agente público - sendo que essa presunção também é válida para os outros agentes estatais. Há um prestígio com relação à palavra do ASP em detrimento da palavra do preso, cabendo a este provar sua versão.

Dois entrevistados traçaram um paralelo entre a oposição processual que existe entre o agente penitenciário e o preso nos processos em sede de execução penal e os policiais militares e o acusado nos processos criminais de conhecimento. Para um deles, a 
palavra do ASP tem grande valor, mas a confiança não é cega. A atribuição de maior valor à palavra do agente dá-se em função do fato dos ASPs precisarem de respaldo em sua atividade profissional. O respeito ao ASP é fundamental e por isso é importante que o juiz valorize a sua palavra no processo. Para o outro juiz que traçou o paralelo, em regra dá-se crédito à fala do ASP, mas o problema reside nas situações em que o agente não sabe dizer o que realmente aconteceu, o que ocorre em aproximadamente metade dos casos.

No que diz respeito à valorização do depoimento do ASP em processos judiciais, a posição dos entrevistados ficou dividida. Para uns, o valor dado à palavra do agente é grande, em função do seu cargo público. Para outros, a presunção de veracidade é relativa, sendo possível que o preso apresente prova em contrário do alegado.

\subsubsection{Categoria 8: Condições de trabalho do ASP}

Esta categoria abordou as condições de trabalho a que estão submetidos os agentes penitenciários na visão do Poder Judiciário. Os oito entrevistados abordaram elementos relativos a tal categoria de análise.

Todos ressaltaram que as condições de trabalho dos agentes são ruins. Cada um enfatizou aspectos diferentes, mas todos concordaram que as condições de trabalho são precárias. Cinco juízes relacionaram a precariedade das condições de trabalho com a superlotação, com o excesso de demanda, com a falta de recursos humanos e materiais etc.

A quantidade de agentes penitenciários é calculada tendo como base a capacidade máxima prevista para a unidade e, como quase todas as unidades prisionais do Estado de São Paulo estão ao menos 100\% acima da capacidade máxima, o número de servidores é insuficiente, explicou um dos entrevistados. Outro destes juízes afirmou que a superlotação também dificulta o trabalho, pois quanto mais pessoas presas, mais problemas o ASP terá que resolver. Outro destacou que, como o número de profissionais é reduzido, o agente que tira muita licença ou falta muito acaba dando mais trabalho do que os presos.

Um dos entrevistados afirmou que o trabalho do ASP é muito insalubre. Para outro, o ambiente de trabalho é muito "carregado", o que faz com que, às vezes, o ASP acabe levando os valores daquele ambiente com ele quando está fora do serviço. O sistema de trabalho do ASP é muito complexo, completou. 
Por fim, de acordo com um dos entrevistados, não são realizados investimentos suficientes para a capacitação e a remuneração dos agentes. Estes investimentos poderiam, inclusive, afastar tendência à corrupção. Na mesma linha, outro juiz disse que os agentes não têm condições ideais de trabalho, em especial, salariais. Para ele, os ASPs são desvalorizados e, se fossem mais valorizados, seriam melhores profissionais. Ainda de acordo com esse mesmo entrevistado, nos Centros de Detenção Provisória o desrespeito para com os presos é maior do que nas outras unidades. Nos CDPs, a estrutura é mais deficiente, já que o diretor é menos profissional.

Foi unânime a posição de que o ambiente de trabalho do ASP é negativo e insalubre dentre as manifestações dos entrevistados. As principais associações foram com a superlotação e a desvalorização profissional. Ademais, foi destacado o fato de o ambiente ser muito “carregado” e esse peso acompanhar o ASP mesmo quando deixa o seu plantão.

\subsubsection{Categoria 9: Fatores emocionais relacionados ao trabalho do ASP}

Esta categoria tratou dos elementos e dos impactos emocionais, que, de acordo com o Poder Judiciário, estão embutidos no exercício da profissão de agente penitenciário. Todas as entrevistas versaram sobre temas implícitos desta categoria.

Dois entrevistados afirmaram que o trabalho desenvolvido pelos agentes é muito tenso. Um deles disse que alguns agentes já foram, inclusive, reféns de presos em rebeliões ou motins, indicando que os agentes estão muito expostos à violência. Ambos disseram que o trabalho é ainda mais tenso nas penitenciárias de segurança máxima, mas, ao mesmo tempo, a proporção entre presos e ASPs acaba por facilitar o trabalho.

Interessante observar que um dos entrevistados afirmou exatamente o oposto, de que o trabalho não é muito tenso.

Três entrevistados destacaram o sentimento de medo e de temor que os agentes sentem no trabalho. Para um deles, o temor é em função do alto risco envolvido na atividade. Para outro, ser agente penitenciário não é tarefa fácil e nem é estimulante, tem que ter vocação.

Dois juízes afirmaram que trabalhar como agente penitenciário produz impactos psicológicos, tendo em vista que alguns ASPs desenvolvem problemas emocionais. 
O nível de estresse que a profissão gera também foi abordado em duas entrevistas. Para ambos, o estresse é decorrente do contato direto que estabelecem com criminosos; um deles destacou que, quanto mais próximo se está dos presos, maior o nível de estresse. O diretor fica mais afastado, mas, de acordo com ele, o bom diretor é aquele que está frequentemente nos raios.

Um dos entrevistados destacou que os agentes penitenciários passam por um processo de "endurecimento", ou seja, passam a naturalizar os conflitos que vivenciam no trabalho.

Em três entrevistas, o fato de levarem a tensão que vivenciam durante o plantão para casa foi abordado. Um dos juízes disse que o ambiente é muito forte, chega a deixar a pessoa impregnada com "ar carcerário". Aos olhos da sociedade, as piores pessoas estão na prisão, o que, para ele, não é verdade. Para o outro entrevistado que também discorreu sobre tal temática, os ASPs têm que tomar, e efetivamente tomam, cuidado com a linguagem que utilizam em casa, porque no trabalho utilizam-se de gírias próprias do sistema prisional.

Medo, estresse e tensão foram os principais destaques nas entrevistas quando o tema em discussão era o impacto psicológico no desempenho da profissão de agente penitenciário. Apenas um entrevistado discordou dos demais e disse não considerar o exercício da função tenso.

O fato da profissão produzir danos psicológicos também foi levantado nas entrevistas. A questão da naturalização dos conflitos e da violência como um dos efeitos do trabalho no cárcere foi apresentado por um dos entrevistados.

\subsubsection{Categoria 10: Impacto da existência do crime organizado na atuação do} ASP

Aqui foram abordados os elementos, percebidos pelo Poder Judiciário, que dizem respeito à existência de grupos organizados de presos e à influência que esses grupos facções - exercem no desempenho da função do ASP. Cinco entrevistados abordaram este tema no decorrer das entrevistas. 
Para um dos entrevistados, as facções criminosas impactam o trabalho do ASP, a ordem pública e o cotidiano prisional. Elas dificultam a reinserção social. Existe uma oposição entre a liderança dos presos e a atividade disciplinar exercida pela administração. A liderança do preso constitui-se como um poder paralelo, o que é altamente negativo. Ademais, as facções intimidam uns servidores e cooptam outros, oferecendo dinheiro ou impondo temor e fazendo ameaças.

No mesmo sentido, outro juiz disse que a facção corrompe os funcionários e oprime os presos, sendo que o risco na atividade do ASP é ampliado em razão da facção. A polícia militar e os agentes penitenciários lutam contra as facções.

Para outro entrevistado, a facção impacta o trabalho do ASP, em cada unidade de forma diferente, dependendo da facção e do perfil do preso que ali está custodiado.

De acordo com outra entrevista, o impacto das facções é paradoxal: ao mesmo tempo em que impacta o trabalho do ASP para o bem, uma vez que o líder da facção mantém “tudo em dia” e faz com que os presos cumpram as regras disciplinares, também é um fator de ameaça, na medida em que a facção atua também fora do presídio; ou seja, ao passo que o dia a dia é mais tranquilo, a atividade profissional é mais perigosa fora dos muros.

Segundo um dos entrevistados, o impacto se dá em relação às agressões físicas cometidas pelos agentes contra os presos. Com a organização dos presos em facções, as agressões cometidas por ASPs diminuíram, pois seria necessário ter mais cuidado ao agredi-los. Isso porque, ao se organizarem, os presos passaram a ter mais consciência de seus direitos e a lutar por eles, às vezes de modo ilícito e ilegítimo. A população carcerária é heterogênea e existem presos que não fazem parte de nenhuma facção, esses são mais subjugados pelos demais presos e pelos ASPs.

A presença das facções criminosas no sistema prisional foi bastante abordada nas entrevistas como um fator gerador de grande impacto na profissão dos agentes penitenciários. O fortalecimento dos grupos organizados de presos produziu mudanças significativas na forma dos agentes exercerem sua profissão. Tanto pela imposição de maior risco no dia a dia, pelo aumento de ameaças e pelo perigo de se tornarem vítimas de agressões, quanto pela facilidade que a presença das facções trouxe para o desempenho profissional. Esse último ponto foi destacado por apenas um dos entrevistados, mas é um dado muito rico e que merece ser discutido no próximo capítulo. 


\subsection{Súmula analítico-descritiva}

O presente tópico sistematiza os principais elementos perceptuais extraídos dos dados coletados e das análises realizadas sobre eles, em forma de itens.

1 - O preparo intelectual, formal e teórico recebeu destaque na percepção do Poder Judiciário. Os juízes entrevistados reconhecem que existe um preparo formal, mas que é insuficiente para que os ASPs desempenhem sua importante função ressocializadora.

2 - A função principal do agente penitenciário é bastante discutida pelos entrevistados. Há uma discussão sobre a função ressocializadora e a função disciplinar, recebendo maior destaque, por parte dos entrevistados, a primeira função.

3 - Percebeu-se uma tendência dos entrevistados a depositar nos agentes penitenciários a responsabilidade pela manutenção da prisão.

4 - A tarefa de testemunhar faltas cometidas pelos presos apareceu com bastante relevo nas entrevistas. O Poder Judiciário percebe essa função como fundamental e também como rotineira para o ASP.

5 - A maioria dos entrevistados mencionou o pouco contato pessoal existente entre os agentes penitenciários e os representantes do Poder Judiciário. Foi apresentada uma visão divergente de um dos entrevistados que considerou importante manter relações próximas e de troca com estes, assim ambos poderiam aperfeiçoar o desempenho profissional.

6 - A visão apresentada pelo Poder Judiciário foi de que não há uma relação hierárquica entre os juízes e os ASPs.

7 - A discussão sobre o papel do Poder Judiciário na análise das faltas graves aparece de modo relevante nas entrevistas. A maneira pela qual o Judiciário percebe o papel e a figura do ASP influencia o entendimento adotado pelos juízes no julgamento das faltas graves.

8 - As denúncias de irregularidades cometidas pelos ASPs estão presentes nos dados, de modo que os entrevistados realizaram uma reflexão sobre as fragilidades destas. 
9 - A relação entre presos e agentes apareceu nas entrevistas como sendo de parceria e não de inimizade; como se ambos estivessem interessados no mesmo objetivo: a ressocialização.

10 - Os conflitos existente entre a aproximação e o distanciamento entre agentes e presos, além das interpenetrações entre os dois universos, foram elementos presentes nas entrevistas.

11 - O tema do poder exercido pelos agentes também é fundamental para a compreensão do universo profissional e esteve presente em mais de uma categoria de análise, sendo um tema considerado como transversal.

12 - Questões como poder, conivência, receio em denunciar e dificuldade de apuração apareceram com ênfase nas entrevistas quando o tema tratado foi a probidade do agente penitenciário.

13 - Os entrevistados valorizam a importância do papel fiscalizador do diretor da unidade prisional quanto às irregularidades cometidas pelos ASPs. Há uma discussão sobre a sua aplicação concreta.

14 - Dentre os principais fatores destacados pelos entrevistados como de risco para os agentes penitenciários estão: a presença das facções criminosas, as superlotações e as questões relacionadas ao excesso de presos em locais inadequados, com o risco de doenças e de violência, como ocorre durante as rebeliões.

15 - A forma como o Poder Judiciário valora a palavra do agente está presente nos dados coletados. Houve uma divergência de posicionamento quanto a este tema, sendo que para alguns juízes a palavra do agente tem valor absoluto e para outros admite-se prova em contrário. Há ainda a posição de que cabe ao ASP provar o que alegar no processo.

16 - Foi unânime entre os entrevistados o fator da insalubridade do ambiente de trabalho dos ASPs, por razões de superlotação e da desvalorização profissional.

17 - Medo, estresse e tensão foram os principais destaques nas entrevistas quando o tema foi o impacto psicológico no desempenho da profissão do agente penitenciário.

18 - A presença das facções criminosas no sistema prisional foi apresentada como um fator gerador de grande impacto na profissão dos agentes penitenciários. Em sua maioria, os entrevistados afirmaram que a organização dos presos aumenta o risco dos ASPs serem vítimas de agressões. Porém, um dos entrevistados apresentou um elemento 
muito interessante: o fato da facção, segundo ele, ter facilitado a tarefa de manutenção da disciplina interna nas unidades prisionais. 


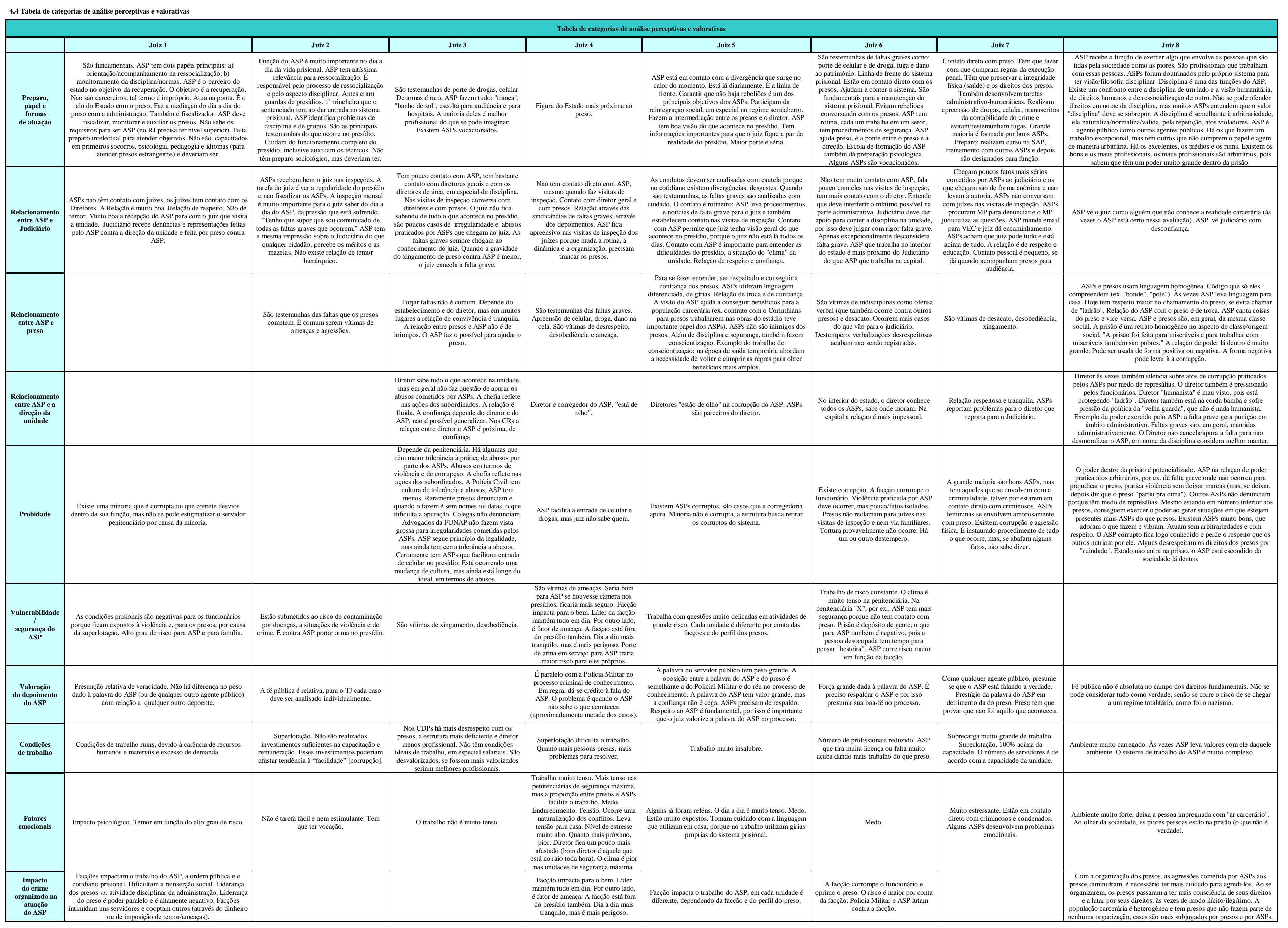


Capítulo 5

\section{OLHARES CONVERGENTES E DIVERGENTES:}

\section{DISCUSSÃO E INTERPRETAÇÃO DOS DADOS}

Este capítulo destina-se a discutir e interpretar os dados produzidos. Será discutida e interpretada cada uma das categorias de análise apresentadas e analisadas no capítulo 4.

Aqui serão cotejados os dados produzidos e organizados em categorias, analisando ainda o que a literatura acadêmica já produziu sobre agentes penitenciários. A literatura acadêmica que será utilizada como base para as discussões já foi explorada e contextualizada no capítulo $2^{290}$.

Neste capítulo, verificar-se-ão as aproximações e distanciamentos entre o que já se produziu sobre os ASPs e a visão que o Poder Judiciário tem sobre essa categoria profissional. Serão traçadas hipóteses e apresentados ensaios sobre a correlação existente entre os dados produzidos a partir das oito entrevistas realizadas e os achados de outros autores sobre os ASPs, levantando-se hipóteses sobre as implicações que a percepção e os aspectos valorativos do Poder Judiciário sobre os agentes penitenciários poderiam produzir. Em alguns casos, não foi encontrada literatura sobre a temática em questão.

A discussão e a interpretação serão realizadas a partir das categorias de análise e, portanto, este capítulo se dividirá em dez itens e se baseará no conteúdo apresentado nos capítulos 2 e 4 .

\footnotetext{
${ }^{290}$ Poder-se-á utilizar como elemento para a discussão bibliografia que não foi apresentada no capítulo 2. Nesses casos os autores e as pesquisas serão contextualizados para que se possa compreender o cenário da produção do material que será utilizado. As obras já apresentadas não serão novamente contextualizadas, podendo o leitor consultar o tópico referente no capítulo 2.
} 


\subsection{Categoria 1: Preparo, papel e formas de atuação do ASP}

Para a discussão e interpretação desta categoria, far-se-á uma subdivisão dentre os três núcleos: o preparo, o papel e as formas de atuação.

\subsubsection{Preparo}

Como apresentado no capítulo anterior, a questão do preparo apareceu de maneira importante nas entrevistas realizadas. Apesar de apenas a metade dos juízes ter se detido especificamente sobre tal tema, a discussão e a interpretação do conteúdo daqueles que o abordaram, em relação com o que diz a bibliografia estudada - que dá bastante ênfase à temática - permitiu uma reflexão muito rica.

Um dos entrevistados ressaltou, como sendo um aspecto positivo da etapa preparatória, o fato de realizarem uma espécie de estágio antes de assumirem o posto propriamente dito. A etapa prática do curso de formação foi apresentada como fundamental pela literatura acadêmica que se debruçou sobre a preparação para o exercício da função de ASP.

O conhecimento adquirido com a prática da profissão é mais valorizado do que o conhecimento teórico e o conhecimento sobre as leis e teorias da execução penal pelos próprios ASPs, de acordo com diversos autores.

BoDÊ assevera que os ASPs sempre estão a demandar maior formação, tanto no momento de ingresso na carreira, quanto como forma de reciclagem. Segundo um dos agentes penitenciários entrevistado por ele, “o bandido está sempre se aperfeiçoando e o agente parado no tempo" 291.

Contudo, essa solicitação é geralmente interpretada pelos responsáveis das escolas de administração penitenciária como demanda por formação formal; e a demanda é, na realidade, por formação com ênfase na prática, para conseguirem desenvolver as atividades no cotidiano prisional. Há uma solicitação para que a formação seja "penitenciarista”, como os sujeitos da pesquisa de BoDÊ a denominaram. Para eles, é preciso investir para

${ }^{291}$ MorAEs, Pedro Rodolfo Bodê de. Op. cit., p. 238. 
que os ASPs não sejam meros carcereiros que têm que lidar apenas com o aspecto disciplinar, é necessário que exerçam funções de caráter pedagógico e sociológico. Porém, a demanda por tal aprendizado específico procura uma ênfase na prática e não apenas na teoria, para possibilitar a aplicação concreta dos conhecimentos no cotidiano ${ }^{292}$.

Como regra, os recém-ingressados na carreira são logo alocados para desempenhar atividades que exigem mais experiência, como uma espécie de ritual de passagem. Em geral, eles não sabem executar aquelas tarefas e se sentem muito assustados ${ }^{293}$. Esse é um dos motivos que leva os ASPs a demandarem cursos mais práticos de formação antes de iniciarem o desempenho das suas funções.

Muito interessante para ilustrar a questão do preparo é a descrição trazida por TAETS sobre o trabalho de Léo ${ }^{294}$. Logo em seu primeiro dia, Léo foi designada para abrir as celas, soltar as presas para que tivessem seu banho de sol e, depois, trancá-las novamente. A dificuldade enfrentada por Léo foi não saber como trancar as celas, pois não conhecia o sistema de duas trancas que era utilizado. Ninguém a havia alertado sobre isso e foi necessário que uma presa lhe auxiliasse a executar a atividade. Léo não teve problema em fazer com que as presas obedecessem a suas ordens, porém ela própria não soube executar sua tarefa. Trancar as celas poderia ser considerado como algo simples, mas como lhe faltava conhecimento sobre esse elemento específico, precisou contar com o auxílio de uma presa ${ }^{295}$.

O primeiro dia de trabalho de Léo e dos demais agentes penitenciários com quem BoDÊ conversou ressaltaram o mesmo ponto.

Adriana TAets também cuidou deste assunto em sua dissertação. Para ela, a crítica realizada pelos ASPs sobre os cursos de formação é de que a formação é demasiadamente teórica e que só é possível aprender sobre o exercício da profissão na prática $^{296}$.

Nos cursos de formação, a preocupação é voltada para o ensino das regras que regem a instituição e também para a necessidade de demarcação das diferenças existentes entre os presos e os agentes, para que os ASPs não se tornem parecidos com os presos ${ }^{297}$.

\footnotetext{
${ }^{292}$ Idem, p. 242.

293 Idem, p. 234-237.

${ }^{294}$ Léo (nome fictício) é uma das agentes penitenciárias entrevistadas por TAETS.

295 TAETS, Adriana Rezende Faria. Op. cit., p. 141.

${ }^{296}$ Idem, p. 141-147.

${ }^{297}$ Esse elemento será mais desenvolvido na categoria 3 deste capítulo, no item 5.3.
} 
Por outro lado, a prática irá ensinar aos ASPs como manter o equilíbrio na tênue fronteira existente entre o cumprir e o descumprir de regras ${ }^{298}$.

Pelo fato do conhecimento prático ser mais valorizado, por ser considerado útil, existe uma rivalidade entre as turmas de agentes mais velhas e mais novas. "Ao voltarmos o olhar para a relação existente entre as diferentes turmas de guarda, marcadas pelo ano de ingresso na profissão, é possível perceber uma tensão calcada no processo de construção de um saber voltado para a vivência no cárcere”, diz TAETS ${ }^{299}$.

FOUCAULT trabalha, em seus escritos, com essa noção de poder-saber de um modo bastante profundo. Segundo ele, toda forma de exercício de poder depende de um simbolismo: quando o simbólico não está presente, a tecnologia do poder não se aplica. E aqui, na relação entre os ASPs mais antigos e os mais novos, há um simbolismo representado pela visão de que apenas a prática ensina a ser um bom agente penitenciário. Neste sentido, os mais antigos na profissão sabem mais e por isso exercem poder em relação aos outros agentes.

O saber e a construção de verdades atuam de modo a criar e a constituir os sujeitos das relações. FOUCAULT aborda a questão da microfísica do poder, ou seja, ele diz que o poder está presente em todas as relações e microrrelações sociais ${ }^{300}$. O fato das turmas mais antigas serem consideradas como detentoras de um saber, que só se aprende na prática, gera uma relação de poder.

CASTRO E Silva observou um semestre ${ }^{301}$ do curso ministrado na Escola de Gestão Penitenciária do Rio de Janeiro. Interessante que, ao menos naquele período, a Escola não contava com docentes em seu quadro e também não tinha verba destinadas a remunerá-los. Portanto, o curso era ministrado por voluntários, que por não perceberem salário não eram cobrados pela direção da Escola, o que fazia com que os atrasos e faltas dos instrutores fossem frequentes ${ }^{302}$.

\footnotetext{
${ }^{298}$ TAETS, Adriana Rezende Faria. Op. cit., p. 143.

299 Idem, p. 145.

${ }^{300}$ Vide FOUCAUlt, Michel. A verdade e as formas jurídicas. Rio de Janeiro: NAU, 2009. FOUCAULT, Michel. Vigiar e punir: nascimento da prisão. Petrópolis: Vozes, 2007. FoUCAULT, Michel. Sobre a prisão. In: _. Microfísica do Poder. 13 ed. Rio de Janeiro: Graal, 1998. p. 129-143.

${ }^{301}$ Segundo semestre de 2004.

302 CASTRO E Silva, Anderson Moraes de. Op. cit., p. 142-169.
} 
Em geral, o curso era ministrado por antigos agentes penitenciários, mas também por policiais civis e militares. Por terem adquirido ao longo de sua "prática cadeeira”, um conhecimento singular, eram vistos como autoridades “nos assuntos” pelos alunos.

Um dos elementos mais comuns observados por CASTRO E SILVA era o instrutor perguntar aos alunos que curiosidades eles tinham sobre o sistema penitenciário. A aula, então, era construída a partir destas respostas. Mas é interessante notar que a observação realizada por ele difere da descrição dada por BODÊ e por TAETS. Ambos destacam exatamente a falta de lições práticas e o excesso de aulas formais sobre normas e teorias. CASTRO E SILVA destaca a completa ausência de referência às normas formais ${ }^{303}$.

Mas, ao mesmo tempo em que as aulas não eram baseadas nas normas oficiais, os agentes eram incentivados a garantirem os direitos dos presos e a cobrar seus deveres, em especial nos temas atinentes à disciplina.

A mensagem passada pelo curso de formação é sobre a insegurança e os riscos gerados pela profissão de agente penitenciário, que jamais pode ter certeza de que sairá com vida da prisão ao final do expediente.

Interessante observar que um dos juízes entrevistados falou da importância de aumentar o preparo intelectual dos ASPs para que os agentes possam ser orientados no exercício da função, buscando alcançar os objetivos da execução penal. Este preparo intelectual estaria relacionado aos conhecimentos em primeiros socorros, psicologia, pedagogia e idiomas. Outro entrevistado falou em preparação sociológica.

Tais juízes estão valorizando conhecimento teórico de diversas áreas do saber para que o agente possa exercer de modo mais satisfatório sua profissão.

Sabe-se que esses elementos, considerados faltantes na formação dos agentes, são especificidades de outras áreas e são exercidas por outros profissionais dentro do sistema penitenciários. Primeiros socorros devem ser exercidos pelos profissionais da Saúde, psicologia pelos psicólogos, pedagogia pelos profissionais da área de Educação e os idiomas pelos intérpretes, para auxiliar os presos estrangeiros. O estudo de Sociologia seria importante para que os ASPs pudessem ter uma maior compreensão do fenômeno prisional, mas isso já é realizado por pesquisadores e estudiosos da temática carcerária.

\footnotetext{
${ }^{303} \mathrm{Um}$ exemplo que ele apresenta refere-se ao chamamento do preso. Um aluno perguntou como deveria chamar os presos e as respostas dadas pelos instrutores foi de que deveria referir-se a eles como "vagabundo", "meu bom interno" ou "preso". Nenhum instrutor fez referência à regra oficial prevista na Lei de Execução Penal de que é a do chamamento nominal.
} 
Mas, como existe uma grande escassez de profissionais no sistema prisional paulista, e por considerarem de extrema importância que os presos recebam tais assistências, os juízes compreendem que os próprios ASPs, por estarem em contato direto com os presos, deveriam suprir essas necessidades e carências do sistema penitenciário.

No que diz respeito à percepção e à valorização do Poder Judiciário com relação aos agentes, vê-se que o Judiciário valoriza a preparação intelectual - e não só prática - do ASP, no sentido de que estaria reconhecendo no ASP não unicamente um profissional de segurança, no sentido estrito, mas um profissional de inteligência, cuja função exige discernimento, conhecimento da execução penal, do penitenciarismo. Seria necessária a compreensão mais ampla dos fenômenos sociais que circunscrevem a prisão e também daqueles presentes em seu interior, por isso consideram importante o conhecimento e a preparação nas disciplinas de Psicologia e Sociologia.

Essa visão do Poder Judiciário é de valoração positiva, o que poderia refletir positivamente na autoimagem do ASP, que se sente desvalorizado, e na imagem que outros profissionais fazem dele.

\subsubsection{Papel}

Muitos dos entrevistados destacaram o fato do agente penitenciário ser o funcionário público que está em contato direto e permanente com os presos, a "linha de frente” do sistema prisional e o "elo de ligação" (sic) entre o Estado e os encarcerados, entre a administração e direção da unidade e os presos.

Em diversas entrevistas, apareceu como fundamental o desempenho da função ressocializadora do trabalho do ASP, somada às funções disciplinares e de garantia do cumprimento das normas do presídio. Interessante notar que o aspecto ressocializador apareceu com maior ênfase nos dados produzidos, sendo que a literatura acadêmica, ao discorrer sobre estas duas funções, conclui que o papel de manutenção da ordem e disciplina é mais presente na rotina dos ASPs do que a função ressocializadora em relação ao preso.

Thompson, por exemplo, afirma que as finalidades declaradas da prisão são incongruentes. O confinamento, a ordem interna, a punição, a intimidação - particular e 
geral - e a regeneração não podem ser realizados pela mesma instituição, e menos ainda, ser atribuição da mesma categoria profissional ${ }^{304}$.

Sendo assim, o objetivo de manter a ordem interna na cadeia e de evitar rebeliões se transforma em prioridade, sendo que os ASPs acabam deixando de se preocupar com a reinserção social do condenado. A preocupação em assegurar a disciplina é legitimada, também, pelas incongruências entre as finalidades da pena e o aparato repressivo. Estas contradições são vivenciadas pelos próprios ASPs, que, por sua vez, se sentem legitimados a adotar as condutas que julgarem necessárias para cumprir os objetivos ${ }^{305}$.

Chauvenet, Orlic e Benguigui avaliam que as alterações legislativas que aumentaram os direitos dos presos resultaram em mais regras a serem cumpridas pelos ASPs, no caso da França. Eles compreendem que este aumento de leis e regulamentos teve um impacto substancial no trabalho dos agentes, não apenas porque eles passaram a ter mais atribuições, mas também porque suas funções ficaram reduzidas à segurança e à disciplina. O aumento dos direitos dos presos levou ao aumento do número de profissionais especializados para desenvolver atividades com eles, como psicólogos, médicos, pedagogos, o que fez com que os ASPs ficassem responsáveis por assegurar o acesso dos presos a esses profissionais e garantir a segurança.

A função do ASP, de acordo com esses pesquisadores, está definida nos regulamentos como uma função meramente instrumental e de execução das normas. Contudo, para executarem seus deveres há que haver um grau de discricionariedade, já que as condutas são decididas levando-se em consideração a oportunidade e a circunstância específica de cada caso. A manutenção da ordem não pode ser definida a priori, a forma como controlam os presos e garantem a segurança e disciplina não são objetos de doutrinas ou teorias, apenas a atuação cotidiana determinará a forma de atuação dos ASPs ${ }^{306}$.

Assim, a função da reinserção social seria uma missão residual e utópica na prática dos agentes penitenciários ${ }^{307}$.

BODÊ discorre sobre a ambiguidade existente entre os papéis ressocializador e disciplinador endereçados ao ASP. Para ele, a importância da ressocialização é bastante enfatizada nos cursos de formação fornecidos aos agentes penitenciários e é também uma

\footnotetext{
304 Thompson, Augusto. Op. cit., p. 22.

${ }^{305}$ Idem, p. 43.

${ }^{306}$ CHAUVENET, Antoinette; ORLIC, Françoises; Benguigui, Georges. Op. cit., p. 17-33.

${ }^{307}$ Idem, p. 35-48.
} 
forma mais valorativa que os ASPs utilizam para se apresentar perante a sociedade: se apresentam orgulhosamente como agentes ressocializadores. Porém, de acordo com os dados que coletou, esta expectativa de ser um agente ressocializador é frustrada tão logo dão início ao desenvolvimento de suas atividades. “(...) quando você chega na cadeia você descobre que o único princípio de ressocialização que existe é a disciplina, é cobrar e exigir disciplina”, disse um agente entrevistado por ele $e^{308}$.

Para KAUfFMAN, os ASPs veem que o objetivo de sua função é evitar fugas e manter a ordem interna. A alta taxa de reincidência - "porta giratória”, como denomina a autora - fez com que os agentes perdessem a ilusão de que seu papel é de atuar para evitar o cometimento de crimes e para a redução da criminalidade. ${ }^{309}$

CASTRO E SiLVA também aborda esse elemento e destaca que na Escola de Gestão Penitenciária a ressocialização não era tema das aulas. Na realidade, o ideal ressocializador nem foi apresentado como um dos objetivos das prisões: o curso ensinava que o objetivo da pena de prisão era apenas a restrição da liberdade do condenado ${ }^{310}$.

SYKES apresenta e discute as contradições das finalidades da pena privativa de liberdade. Para ele, os custodiadores têm clareza de que sua função mais importante é evitar fugas e rebeliões ${ }^{311}$. Neste sentido, além de ter que estar sempre atento para prevenir qualquer ação que possa resultar em fuga, o guarda deve auxiliar a construir barreiras psicológicas que desestimulem tais condutas por parte dos presos.

Além das consideradas funções mais óbvias, como revistar celas em busca de objetos ilícitos, os ASPs devem se preocupar com ações que possam parecer inocentes ${ }^{312}$.

A análise dos autores citados acima aparece de modo semelhante na fala de um dos juízes entrevistados. Segundo ele, os ASPs foram doutrinados pelo próprio sistema para ter visão e filosofia disciplinar. A disciplina é uma das funções do ASP, mas existe um confronto entre a disciplina e a visão humanitária, de direitos humanos e de ressocialização.

\footnotetext{
${ }^{308}$ MoraEs, Pedro Rodolfo Bodê de. Op. cit., p. 240.

${ }^{309}$ KaUfFMAN, Kelsey. Op. cit., p. 46.

${ }^{310}$ Castro e Silva, Anderson Moraes de. Op. cit., p. 155.

${ }^{311}$ SYKES, Gresham M. Op. cit., p. 18.

${ }^{312}$ Idem, p. 21.
} 
O entrevistado discorda da sobrevalorização do ideal disciplinador. Para ele, não se pode ofender direitos em nome da disciplina, mas, segundo ele, muitos ASPs entendem que o valor “disciplina” deve ser sobreposto ao valor ressocialização.

Ele aponta para o perigo que existe em valorizar em demasia a disciplina, já que muitas vezes se assemelha à arbitrariedade, pois naturaliza, normaliza e valida, por meio da repetição, atos violadores de direitos.

Para o Poder Judiciário, de acordo com os dados produzidos, garantir que não haja rebeliões é um dos principais objetivos dos ASPs, ao mesmo tempo em que a ressocialização é fundamental. É, então, muito importante o papel de identificar problemas de disciplina e de controvérsia entre grupos de presos.

Os entrevistados deram destaque ao fato de o ASP ser responsável pelo funcionamento completo do presídio, por serem responsáveis por realizar todas as tarefas: auxiliar técnicos, “tranca”, "banho de sol”, escolta para audiência e para hospitais. Ou seja, são responsáveis, de acordo com a visão do Poder Judiciário, por fazer com que o fluxo programado para o funcionamento da cadeia seja seguido.

Outro entrevistado disse que os agentes têm uma boa visão do que acontece no presídio e possuem informações importantes para que o juiz fique a par da realidade da unidade prisional. Este juiz destacou, portanto, o fato de os ASPs serem aqueles que mais conhecem o que se passa na unidade prisional, o que é fundamental para que o juiz aproveite esse conhecimento do agente, passando a compreender melhor o funcionamento da unidade pela qual é responsável.

Com relação ao aspecto disciplinar, quatro juízes, ou seja, metade dos entrevistados, citaram como parte rotineira da atividade profissional do agente o testemunho das faltas cometidas pelos presos.

O fato dos agentes serem testemunhas do cometimento de faltas por parte dos presos ter aparecido com frequência nas entrevistas demonstra que o aspecto disciplinar está presente na percepção do Poder Judiciário sobre a função dos ASPs, em especial - o que faz todo sentido - naquelas atividades que chegam ao conhecimento dos juízes para que sejam apreciadas e decididas. Como um dos papeis dos juízes de execução é julgar faltas graves, e os ASPs são testemunhas do cometimento das mesmas, é natural que tal elemento tenha aparecido com frequência. 
Para outro entrevistado, os agentes são responsáveis por preservar a integridade física, compreendida como a saúde e os direitos dos presos, ao passo que devem assegurar que os presos cumpram as regras da execução penal. Tal afirmação é interessante de ser interpretada à luz do que apresenta CASTRO E SILVA sobre este ponto. Segundo o autor, assegurar os direitos dos presos não deve ser um objetivo do ASP em razão da importância que a garantia dos direitos dos cidadãos assume em um Estado Democrático de Direito. Não é esse o caso. A importância reside apenas no fato de que garantir o acesso do preso aos seus direitos é uma forma de reduzir conflitos, violência por parte dos presos e até mesmo rebeliões ${ }^{313}{ }^{314}$.

Em outra entrevista foi destacado o fato de que alguns ASPs são responsáveis por desenvolver tarefas administrativo-burocráticas, o que é importante para compreender que do total dos agentes penitenciários contratados pelo Estado, nem todos trabalham nesta função, o que aumenta ainda mais o déficit de funcionários - crítica constante dos ASPs, especialmente considerando-se o grau de superlotação das penitenciárias paulistas.

Percebeu-se que o Poder Judiciário valoriza, e muito, a função ressocializadora em detrimento da função disciplinar dos agentes. A literatura acadêmica demonstra que, na prática, é a função disciplinar que consome o tempo do agente penitenciário e que não há dedicação para a função ressocializadora, tornando-a inviável. Ao valorizar a função ressocializadora e colocar o ASP como sujeito fundamental deste objetivo, o Poder Judiciário está esboçando uma valoração positiva sobre o agente. Retira-o do papel de abrir e fechar cadeados para elevá-lo à posição de apoiador de um processo mais amplo, em que portas e janelas podem ser abertas, descortinando um novo caminho para os presos.

\footnotetext{
${ }^{313}$ Castro e Silva, Anderson Moraes de. Op. cit. p. 151.

${ }^{314}$ A história do surgimento do Primeiro Comando da Capital - PCC - relaciona-se diretamente com este elemento. O PCC teria surgido para opor-se à opressão do sistema carcerário e para lutar pelos direito da população prisional. Para mais informações sobre esse tema, vide BIONDI, Karina. Junto e misturado: uma etnografia do PCC. São Paulo: Terceiro Nome, 2010. (Coleção Antropologia Hoje). TEIXEIRA, Alessandra. Dispositivos de exceção e novas racionalidades do sistema punitivo: o surgimento do PCC e o modelo RDD. Perspectivas. Revista de Ciências Sociais da UNESP, v. 36, p. 175-208, 2009. Disponível em: $<$ http://seer.fclar.unesp.br/perspectivas/search/results>. Acesso em: 25 dez. 2012. DiAs, Camila Caldeira Nunes. Violência, PCC e prevenção do crime. In: Tertúlias Criminológicas, sobre crime, prevenção e violência. Encontro Semanal de 21 ago. 2012. Disponível em: <http://atualidadesdodireito.com.br/tertulias/exposicoes/>. Acesso em: 25 dez. 2012.
} 
A posição de ser um sujeito da ressocialização e um auxiliar do preso neste processo coloca o agente penitenciário em outro patamar, acima do que a realização de tarefas apenas disciplinares o mantém. O Poder Judiciário expressa com esta percepção a grande valorização que tem da carreira de agente penitenciário e demonstra que o caminho para a ressocialização deve, necessariamente, envolver os ASPs.

\subsubsection{Formas de atuação}

Interessante destacar neste item que os juízes entrevistados expressaram as concepções que o Poder Judiciário possui sobre os agentes penitenciários. Os dados que dizem respeito às formas de atuação dos ASPs apresentaram-se carregados de julgamentos e pressuposições. Os entrevistados disseram que a maioria dos ASPs é formada por bons profissionais, sérios e “melhores do que se pode imaginar”. Além disso, afirmaram que alguns são vocacionados para a profissão.

Ao dizer que são “melhores do que se pode imaginar”, há, implicitamente, uma concepção de que outros imaginam que os ASPs sejam piores do que são de fato. Neste sentido, pode-se destacar que a presença de elementos valorativos e as percepções formadas sobre os ASPs estão inseridas em um contexto onde, para esse entrevistado, os agentes são vistos como piores do que são.

Ao ressaltarem que alguns agentes são vocacionados para a profissão, fica implícito que outros não o são. Porém, o fato da colocação feita pelo entrevistado ter ressaltado o aspecto positivo denota - o que também é possível de perceber em muitas outras manifestações destes e de outros entrevistados - que o Poder Judiciário tem uma percepção positiva sobre os agentes.

Outro juiz disse que o ASP é um agente público como qualquer outro. Aqui, percebe-se uma colocação valorativa também, mas que tende a igualar os agentes aos demais funcionários públicos. Para ele, há agentes que fazem um trabalho excepcional, mas outros não cumprem o seu papel e agem de maneira arbitrária. Ou seja, este entrevistado está pontuando que, como em qualquer outra carreira, existem os profissionais que executam suas funções dentro dos conformes e os que cometem abusos. Neste ponto, 
ele está colocando os agentes penitenciários em paralelo com os demais agentes públicos e demonstrando a forma como percebe esta e as demais carreiras públicas.

\subsection{Categoria 2: Relacionamento entre os ASPs e o Poder Judiciário}

Três foram os elementos principais que se apresentaram nesta categoria. A discussão e a interpretação dos dados serão feitas separadamente para cada um deles. São eles: o contato entre o ASP e o Poder Judiciário, as irregularidades cometidas nos presídios - por presos e por agentes - e o julgamento das faltas graves.

\subsubsection{Contato entre o ASP e o Poder Judiciário}

A maioria dos entrevistados relatou ser o contato pessoal entre o juiz e o ASP reduzido, limitando-se aos processos e aos procedimentos judiciais que contêm depoimentos prestados pelos agentes. Extrai-se das entrevistas realizadas que durante as visitas de inspeção mensais, os juízes travam maior contato com o diretor da unidade e com os presos do que com os agentes. Apenas um entrevistado afirmou que o contato pessoal é rotineiro e dá-se quando os ASPs levam procedimentos e notícias de falta grave para o juiz e também durante as visitas de inspeção.

Tal dado chama atenção, uma vez que a opção metodológica do trabalho foi entrevistar juízes de execução para extrair daí as percepções que o Poder Judiciário tem sobre os agentes. Optou-se por entrevistar os juízes da VEC por estarem mais próximos dos presídios e do que lá acontece por atribuição legal. Contudo, o que os dados mostram é que mesmo estes juízes que estão mais próximos deste universo se consideram distantes dos ASPs. O que leva a um questionamento sobre o real envolvimento existente entre estas duas figuras centrais na execução penal: parece que não se relacionam e que cada um exerce seu papel sem se aproximar do outro.

O entrevistado que disse ter relação próxima com os agentes está agregando mais valor à função do ASP e reconhecendo que estabelecer relações de proximidade com os agentes é fundamental para o desempenho da sua profissão como juiz de execução 
criminal. Este entrevistado diz que a inspeção mensal é muito importante para que o magistrado tenha conhecimento sobre o dia a dia do ASP e da pressão que o agente está sofrendo, além de possibilitar que obtenha informações sobre o "clima” da unidade e sobre as demandas dos presos. Neste sentido, o contato entre o Poder Judiciário e o ASP permite que o juiz possa ter uma visão geral do que acontece no presídio, o que é essencial uma vez que o juiz não está lá todos os dias, ao passo que os ASPs estão.

Mas, mesmo sendo pequeno o contato entre juízes e ASPs - para a maioria dos entrevistados -, a qualidade dessa relação foi retratada como positiva, como uma relação de respeito, de educação, de confiança e não de temor hierárquico. Este elemento demonstra uma percepção por parte do Poder Judiciário de que a relação com os agentes é positiva e cordial, mas, para além disso, não há temor hierárquico, o que vale dizer que os juízes não percebem que haja uma relação de hierarquia entre os agentes e o Poder Judiciário.

\subsubsection{Irregularidades cometidas nos presídios}

De acordo com as entrevistas, os juízes consideram que as faltas graves cometidas por presos sempre chegam ao conhecimento do Poder Judiciário para que o procedimento legal seja seguido.

Tal percepção, expressada pelo Judiciário, não considera as importantes observações apresentadas por CASTRO E SILVA, de que existe uma ordem informal permeada de negociações que regem as relações entre presos e agentes penitenciários. Esta ordem informal estabelece que a adoção do procedimento oficial de falta grave é a última das punições aplicadas pelos ASPs aos presos. Em primeiro lugar, optam por negociar a violência física. A abertura do procedimento de apuração de falta grave é considerada, pela "lei da cadeia”, como mais grave do que o castigo físico. Neste sentido, as faltas graves que chegam ao conhecimento do Poder Judiciário seriam apenas uma pequena parcela do universo das faltas realmente cometidas. De acordo com as normas que regem as relações entre presos e agentes, a adoção do procedimento formal "atrasa” a vida do preso, ao passo que aplicar castigo físico "adianta”315.

${ }^{315}$ CASTRO E Silva. Op. cit. 
Sendo assim, se os dados produzidos forem cotejados com as ideias apresentadas por CASTRO E SiLVA, ter-se-á que a análise realizada por este autor não está presente na percepção do Poder Judiciário. A percepção deste Poder é de que os trâmites oficiais são seguidos; em geral, os entrevistados parecem ignorar a existência da ordem informal nas relações no cárcere.

O entrevistado que apresentou uma visão diversa não o fez no mesmo sentido de CAStro E Silva. Para ele, as faltas graves que não chegam ao conhecimento do Poder Judiciário são de menor gravidade. Na sua visão, seriam aquelas em que os ASPs são vítimas de indisciplinas, como ofensa verbal e desacato, sendo que, nestes casos, os próprios agentes optam por não registrá-las.

No que diz respeito às irregularidade cometidas pelos ASPs, os juízes apresentaram a visão de que não são comunicados de todas elas, ao contrário, ficam sabendo apenas de uma pequena parcela.

Neste sentido, para o Poder Judiciário as faltas cometidas pelos presos não são filtradas e chegam ao conhecimento dos juízes, ao passo que as irregularidades cometidas por ASPs passam por tantos filtros que "ficam represadas" e não chegam ao conhecimento do Poder Judiciário.

Deve-se dar destaque ao fato de os juízes colocarem-se em uma postura passiva diante das faltas graves que ocorrem na unidade prisional. Esta postura, apesar de estar respaldada no princípio jurídico da inércia da jurisdição, poderia ser interpretada como uma forma de defesa e de não ingressar em uma seara espinhosa como as irregularidades cometidas por agentes - ao não notificarem todas as faltas que presenciam - e por presos.

Ao juiz não é permitido investigar novas demandas que não lhes foram apresentadas, porém não é defeso que reflitam sobre elas para compreender o complexo contexto em que aquelas que chegam estão inseridas e, desta forma, fazer uma análise mais abrangente de cada caso concreto de modo a poder interferir mais conscientemente e de forma direcionada para o alcance dos objetivos da execução penal.

Importante observar que, de acordo com KAUFFMAN, existe uma percepção por parte dos ASPs de que os "tribunais” não podem solucionar os problemas e conflitos que existem dentro das unidades prisionais entre os agentes e os presos. Com base nesta visão, 
os ASPs passam a depositar sua confiança no sistema interno de sanções que é baseado em uma ordem informal ${ }^{316}$.

De acordo com os agentes penitenciários entrevistados por KAUFFMAN, o ASP que segue com frequência o procedimento formal fica mal visto, pois isso seria um indicativo de que ele não consegue manter o controle da prisão. Nota-se que há não apenas uma descrença nas soluções dadas pelo Poder Judiciário: mais do que isso, há uma visão de que optar por soluções oficiais é desmoralizante, o que significaria que o ASP é fraco e que não consegue alcançar seus objetivos.

\subsubsection{Julgamento das faltas graves}

A percepção que o Poder Judiciário tem acerca dos ASPs e do funcionamento do sistema penitenciário afeta diretamente a forma pela qual julgam os procedimentos de faltas graves que chegam até seu conhecimento.

Ao partir da percepção de que a ordem formal é a responsável por organizar o cotidiano carcerário, os juízes acabam por acatar a grande maioria das faltas graves e não questionar a palavra apresentada pelo ASP nos procedimentos, adotando uma postura pouco crítica.

Apenas um dos entrevistados fez uma ressalva, que dialoga, inclusive, com a reflexão apresentada por KAUfFMAN. Para este juiz, quando os ASPs figuram como testemunhas, as faltas graves são analisadas com cuidado, demonstrando certa ressalva quanto ao único testemunho ser do agente.

Segundo KAUfFMAN, a regra número 5 no código de conduta informal dos agentes penitenciários $^{317}$ é sempre apoie um ASP em uma disputa com um preso ${ }^{318}$. Tal regra estabelece que os ASPs devem dar apoio incondicional aos colegas de profissão, o que

\footnotetext{
${ }^{316}$ KAUfFMAN, Kelsey. Op. cit.

${ }^{317} \mathrm{O}$ código de ética informal apresentado por KAUFFMAN é composto por nove normas, são elas: sempre ir ao auxílio de outro ASP quando esteja em situação de perigo; não levar droga para dentro da unidade para um preso usar; não delatar um ASP para um preso; nunca fazer um colega ASP “ficar mal” na frente de um preso; sempre apoie um ASP em uma disputa com um preso; sempre apoie as sanções impostas por agentes aos presos; não atue como um preso; mantenha a solidariedade entre os ASPs em detrimento dos grupos externos; e demonstre preocupação por um colega agente. KAUFFMAN, Kelsey. Op. cit. Vide infra item 2.5 no capítulo 2.

${ }^{318}$ KAUfFMAN, Kelsey. Op. cit., p. 101.
} 
incluiria o dever dos demais ASPs de testemunhar corroborando a versão apresentada pelo colega, mesmo nas situações em que não tenha presenciado o ocorrido ${ }^{319}$.

Outro entrevistado afirmou que o Poder Judiciário deve adotar a conduta que interfira o mínimo possível na esfera administrativa, já que o papel que os juízes devem desempenhar é o de apoio às atividades de contenção e de disciplina. Por esta razão, devem julgar com rigor as faltas graves, uma vez que são atos de indisciplina e de desrespeito às normas. Para dar apoio às atividades de manutenção da disciplina, as faltas graves, que têm os agentes como vítimas, devem ser julgadas com rigor. Em decorrência, apenas excepcionalmente uma falta grave deve ser desconsiderada.

Aqui se apresenta a visão de que o papel da Vara de Execução Criminal é apoiar a atividade do ASP. Há uma valoração muito positiva do papel do ASP, ao mesmo tempo em que há um reconhecimento da dificuldade em se executar este trabalho, de modo que o apoio do Poder Judiciário faz-se importante. Neste sentido, é considerado fundamental que o ASP possa contar com o respaldo do Poder Judiciário para desempenhar suas funções disciplinares.

Assim, este juiz está revelando sua opção política baseada em sua compreensão do problema. Ao optar por tal postura, de respaldar os agentes e julgar as faltas graves de modo a valorizar seu depoimento e sua profissão, manifesta uma forma consciente e importante de interferir nos rumos da execução penal. Se os agentes sabem que seus depoimentos serão respaldados pelo Poder Judiciário, eles poderão começar a pensar estrategicamente no uso que farão disso e passarão a perceber o acesso ao Poder Judiciário como mais uma das ferramentas que dispõem para auxiliá-los a desempenhar sua função disciplinar $^{320}$.

Aqui cabe um questionamento. Se o Judiciário não respaldasse o ASP, o próprio sistema seria colocado em risco, pois as palavras dos agentes do Estado estariam sendo sempre questionadas e colocadas à prova, retirando-lhes poder ${ }^{321}$. Mas, ao mesmo tempo, o

\footnotetext{
${ }^{319}$ Idem, p. 101-104.

${ }^{320}$ Esse elemento será discutido na categoria 7, item 5.7.

${ }^{321}$ Em sentido semelhante, conclusões da pesquisa "Prisão Provisória e Lei de Drogas: um estudo sobre os flagrantes de drogas na cidade de São Paulo” realizada pelo Núcleo de Estudos da Violência -NEV/USP: "De acordo com os autos, $74 \%$ dos casos contaram apenas com o testemunho dos policiais que realizaram a apreensão do(a) acusado(a), não estando presente nenhuma outra testemunha civil. O medo das pessoas em se expor é o que leva, na opinião de muitos entrevistados, à ausência de testemunhas civis em casos de tráfico de drogas. Tendo em vista esta dificuldade, um promotor destacou a importância da testemunha policial, na qual 'ou você acredita ou você não acredita'. Segundo ele o crime de tráfico prima pela inexistência de testemunha civil e se os policiais forem obrigados a conseguir testemunha civil 'ou eles não vão conseguir
} 
juiz tem o dever de ser imparcial. Este é um elemento que fundamenta todo o sistema jurídico. Tem-se, portanto, uma oposição entre uma postura política (respaldar o ASP) e uma postura constitucional/principiológica (imparcialidade e presunção de inocência).

\subsection{Categoria 3: Relacionamento entre os ASPs e os presos}

Foram extraídos quatro temas centrais que apareceram nesta categoria de análise: faltas, parceria, diferenciação ASP-preso e poder na relação entre ASP e preso.

\subsubsection{Faltas}

Um dos aspectos que apareceu de modo intenso sobre a relação entre o ASP e o preso é o fato dos agentes serem testemunhas das faltas cometidas pelos presos, além do fato de serem eles as vítimas destas faltas. Como já foi realizada uma discussão acerca das faltas graves na categoria 2, aqui faz-se apenas o destaque de que, na percepção do Poder Judiciário, as faltas são centrais para a compreensão do relacionamento que se estabelece entre os ASPs e os presos, sendo, assim, uma das importantes formas de interação entre estas duas personagens.

Nesta forma de interação, o ASP exerce o papel de fiscalizador das condutas dos presos, de censor, estabelecendo os limites entre o permitido e o proibido e gerando um procedimento que pode desembocar em uma punição. Geralmente, o resultado é a punição, como se discutiu na categoria 2. Mas, somam-se aos elementos já discutidos o fato dos diretores das unidades atribuírem este poder aos $\operatorname{ASPs}^{322}$ e o Poder Judiciário adotar a postura de valorizar a palavra do ASP nos processos $^{323}$.

\footnotetext{
fazer nenhuma prisão, ou quando essas testemunhas forem arroladas elas vão ser extraídas do próprio contexto do traficante e ajudarão a encobertá-lo', concluiu o entrevistado. Novamente, aparece para os operadores como algo naturalizado fato do crime de tráfico não apresentar testemunhas que possam de fato contribuir com uma melhor apuração do caso”. JESUS, Maria Gorete Marques de; Oı, Amanda Hildebrand; Rocha, Thiago Thadeu da; LAGATTA, Pedro. Núcleo de Estudos da Violência - NEV/USP. Prisão Provisória e Lei de Drogas: um estudo sobre os flagrantes de drogas na cidade de São Paulo. Sumário Executivo. São Paulo: Open Society Institute. Publicado em: 2011. Disponível em: $<$ http://www.nevusp.org/downloads/down254b.pdf>. Acesso em: 5 jan. 2013.

${ }^{322}$ Esse elemento será discutido na categoria 4, item 5.4.

${ }^{323}$ Esse elemento será discutido na categoria 7, item 5.7.
} 


\subsubsection{Parceria}

O Poder Judiciário tem a percepção de que a relação entre os presos e os ASPs é de parceria. De acordo com diversas entrevistas, a relação de convivência é tranquila e não de inimizade, sendo que o agente faz o possível para ajudar os presos.

Não há, de acordo com o Poder Judiciário, uma oposição entre presos e agentes, uma vez que os ASPs são parceiros dos presos na busca da ressocialização ${ }^{324}$.

O ASP teria, assim, aos olhares do Poder Judiciário, a importante função de conscientizar os presos sobre seus deveres e de assegurar que seus direitos não lhe sejam negados.

SYKES afirma que os agentes realmente devem conscientizar os presos sobre seus deveres, porém, para o autor, essa tarefa não está atrelada à intenção de ajudar os presos, mas sim de assegurar que os próprios ASPs cumpram a função de manter a ordem e a disciplina na unidade e, especialmente, evitar fugas e rebeliões. Para ele, os agentes têm que adotar diversas posturas para garantir o cumprimento das normas e dentre elas está a construção das barreiras psicológicas que funcionem como desincentivo para os presos descumprirem as normas.

Mas, ao mesmo tempo, os ASPs têm a função de transformar “criminosos” em "não criminosos”, o que é bastante complicado para estes, pois não se sabe os meios para alcançar esse objetivo $^{325}$.

KAUFFMAN também faz uma análise que dialoga com o apresentado por SYKES, ao dizer que duas formas de imposição do poder utilizadas pelos ASPs fundamentam-se na utilização de argumentos racionais como forma de convencer os presos a seguirem o que lhes foi dito pelo ASP, a persuasão e a coerção. Em geral, os argumentos mais utilizados fazem referência às sanções. Quando as sanções não podem ser aplicadas pelo agente, temse a persuasão; quando a sanção está no âmbito de domínio do agente, tem-se a coerção ${ }^{326}$.

\footnotetext{
${ }^{324} \mathrm{O}$ aspecto ressocializador já foi discutido na categoria 1, item 5.1.

${ }^{325}$ SYKES, Gresham. Op. cit.

${ }^{326}$ KAUfFMAN, Kelsey. Op. cit.
} 
O Poder Judiciário apresenta a mesma análise da literatura sobre o fato dos ASPs aconselharem os presos a seguirem as regras da unidade prisional e a lei, porém a interpretação dada a este fato é diversa. Para a literatura apresentada, os ASPs lançam mão deste recurso como mais uma ferramenta para a manutenção da ordem na unidade, enquanto que, para o Judiciário paulista, ela se dá no sentido de auxiliar o preso em seu processo de ressocialização.

\subsubsection{Diferenciação ASP-Preso}

A problematização da diferenciação entre os agentes penitenciários e os presos está presente nos dados produzidos e também na literatura estudada.

O elemento fundamental destacado pelo Poder Judiciário com relação a este ponto é a utilização da mesma linguagem, baseada em gírias típicas das cadeias, por presos e por agentes. Um dos entrevistados explica que os agentes utilizam esta linguagem para se fazer entender e conquistar a confiança dos presos. Mas o ponto principal que foi ressaltado é que os agentes acabam utilizando esta linguagem também fora de seu ambiente de trabalho e esforçam-se para não utilizá-la, em especial, quando estão com a família.

Um entrevistado destacou um ponto fundamental para a compreensão dos agentes penitenciários: o fato de serem da mesma classe e origem social dos presos. Esse aspecto é bastante tratado pela literatura.

BoDE $\hat{E}^{327}$ destaca que, por serem os ASPs e os presos oriundos da mesma classe social, os ASPs veem a prisão como “parte possível do seu destino”. Ele chama atenção para a construção da identidade de trabalhador e da importância que isso tem na formação social dos ASP. Com o ingresso no sistema penitenciário, no papel de agente da lei, o indivíduo forma ou reforça sua identidade de trabalhador, que se distancia da identidade dos "bandidos" e "vagabundos", apesar das enormes semelhanças de classe entre eles. É neste sentido que BoDÊ associa a aplicação da violência física contra os presos como uma tentativa de "quebrar o espelho", e reforçar as diferenças entre os dois grupos, como se o ASP estivesse demarcando sua identidade de trabalhador como distante da identidade de preso.

\footnotetext{
${ }^{327}$ MORAES, Pedro Rodolfo Bodê de. Op. cit.
} 
Não se está aqui pretendendo mostrar que uma percepção é mais próxima da realidade do que outra. O objetivo é contrapor visões e dialogar com elas, sem realizar um juízo de valor sobre uma ou outra posição. Ademais, o tempo e o local das afirmações devem ser considerados. Além disso, o papel social e a experiência de seus autores devem ser levados em conta quando da interpretação das falas.

Com relação ao exemplo do aprendizado da linguagem de gírias típicas da cadeia, BODÊ e SABAINI destacam que os agentes precisam aprender como “pensa o preso” para poder assegurar a ordem interna na penitenciária. "Para a maioria dos agentes, a execução

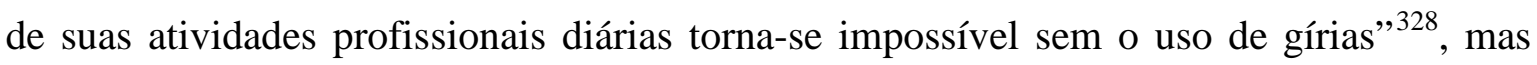
este aprendizado tem um custo alto com relação à identidade do agente, pois existe um perigo de que ocorra um “contágio moral” em razão da aproximação excessiva. A dificuldade reside em saber dosar a aproximação e o distanciamento entre ASP e preso ${ }^{329}$.

TAETS $^{330}$, ao apresentar a história de Solange ${ }^{331}$, também aborda este conflito e a dificuldade dos ASPs em se diferenciarem dos presos. Solange sentia-se muito parecida com as presas que vigiava, já que, inclusive, conhecia algumas delas do bairro em que morava. Solange percebia que eram da mesma classe social e que também tinham certas condutas muito semelhantes, como consumir entorpecentes.

Este foi um conflito vivido por Solange, que além de se identificar com as presas, ainda teve um irmão que foi preso, o que dificultava ainda mais sua tarefa, já difícil, de traçar uma diferenciação clara entre os agentes penitenciários e os presos. A diferenciação acabava dando-se pelo fato das presas possuírem um número de matrícula no sistema prisional e estarem do "lado de lá” das grades.

Depreende-se da entrevista do juiz e da literatura analisada o reconhecimento de uma dificuldade enfrentada pelos ASPs: a diferenciação deles em relação os presos.

\footnotetext{
${ }^{328}$ SABAINI, Raphael. Op. cit., p. 89. A fala de um dos agentes penitenciários entrevistados pelo autor é ilustrativa desta situação: "É outro idioma, e se você não souber você não consegue se comunicar com os caras \{os presos\}. Como é que você vai dar ordens para eles? Lá dentro, por exemplo, não tem essa de 'vai ser servida a refeição’, o que tem é: ‘vamo pagá a bóia’. Se você não sabe que bóia é comida, imagina as outras gírias, então. Se você não sabe essas coisas, tá perdido. Ou então, o preso fez cagada e você fala que ele tem que ir pro pote. Não tem essa de 'você vai para o castigo'”. SABAINI, Raphael. Op. cit., p. 90.

${ }^{329}$ MorAes, Pedro Rodolfo Bodê. Op. cit., 251.

${ }^{330}$ TAETS, Adriana Rezende Faria. Op. cit.

${ }^{331}$ Solange (nome fictício) é uma das agentes penitenciárias entrevistadas por TAETS.
} 


\subsubsection{Poder}

Apenas um dos juízes entrevistados abordou a relação de poder existente entre preso e ASP. Por ser esta uma pesquisa qualitativa e ser este conteúdo apresentado na fala deste entrevistado relevante para a compreensão da percepção do Poder Judiciário sobre os agentes penitenciários, far-se-á uma discussão e interpretação dos elementos colhidos nesta entrevista.

Este juiz destacou que o poder é amplificado dentro da cadeia e que, portanto, os ASPs possuem um grande poder lá dentro. Este poder pode ser usado de forma positiva ou negativa, sendo que a forma negativa pode levar à corrupção.

Foi apresentado por este entrevistado que o poder dos ASPs pode levar à prática de corrupção, mas na realidade os agentes possuem poder suficiente para decidir sobre a vida e a morte dentro da unidade. Isso se dá porque os presos encontram-se privados de sua liberdade e sob total tutela do Estado, sendo o ASP o único representante do Estado dentro das prisões responsável por assegurar seu acesso à saúde, itens de higiene e alimentação.

Este mesmo entrevistado, que ressaltou a importância das relações de poder, salientou que a sociedade não fiscaliza o que se passa no interior das unidades, o que acaba deixando os ASPs em uma situação em que podem praticar irregularidades e não serem denunciados e responsabilizados por isto.

ADRIANA TAETS ${ }^{332}$ desenvolve essa temática e assevera que o exercício do poder que é amplificado no interior das cadeias - gera uma sensação de prazer grande nos agentes penitenciários, sendo essa uma das razões pelas quais os agentes prisionais se mantêm na profissão mesmo identificando-a como insalubre, tensa e perigosa.

Segundo Léo, agente penitenciária personagem das narrativas de TAETS, esse prazer pode levar o agente a contrair a "síndrome do pequeno poder", em que as [os] agentes abusam do poder de disciplina ou do poder de atrapalhar o cumprimento de pena dos presos e dificultar que passem a ter direito à progressão de regime e outros benefícios. Léo chama esse poder de "poder da caneta”.

\footnotetext{
332 TAETS, Adriana Rezende Faria. Op. cit.
} 
KAUFFMAN ${ }^{333}$ dá bastante destaque ao poder exercido pelos agentes penitenciários frente aos presos e afirma que este é utilizado para que os agentes alcancem seus objetivos de manutenção da disciplina. Segundo ela, existem seis maneiras de expressar e impor o poder frente aos presos: autoridade, persuasão, induzimento, manipulação, força e coerção.

Não se pode falar no relacionamento entre presos e agentes e não incluir na análise as relações de poder. Os presos estão privados de liberdade contra sua vontade e os ASPs são os responsáveis por mantê-los nesta condição e, ademais, cumprindo as regras das unidades prisionais. Os ASPs, como destacado pelo Poder Judiciário ${ }^{334}$, representam o elo entre o Estado e o preso e fazem a ponte entre os presos e o Estado. Todas as relações que implicam imposição pressupõem a existência de uma relação de poder, legal ou ilegal.

Os ASPs são detentores de um poder concedido pelo Estado e pelas normas oficiais. Contudo, o que se discutiu neste item foram também aspectos que decorrem de um abuso no exercício do poder.

\subsection{Categoria 4: Relacionamento entre os ASPs e a direção da unidade prisional em que trabalham}

O elemento que mais se destacou nesta Categoria foi a vigilância exercida pelo diretor da unidade sobre as ilegalidades e os abusos cometidos por agentes penitenciários.

O Poder Judiciário conferiu destaque à importância de tal papel do diretor, porém os entrevistados divergiram sobre o fato dele cumprir esse papel ou não.

Para uma parte dos entrevistados, o diretor fiscaliza a atuação do ASP para evitar e punir a prática de abuso, desvio, corrupção e violência. Mas, para outra parcela dos juízes, o diretor tem conhecimento das irregularidades praticadas pelos ASPs, mas não toma nenhuma providência para coibir tais ações ou responsabilizá-los ${ }^{335}$.

Os motivos pelos quais o diretor silencia sobre as irregularidades cometidas pelos agentes também foi objeto de divergência: para uns isto se dá em razão da conivência e para outros por medo de sofrer represálias.

\footnotetext{
${ }^{333}$ KAUfFMAN, Kelsey. Op. cit.

${ }^{334}$ Elemento apresentado na categoria 1, item 5.1.

${ }^{335}$ Esse tema será objeto da discussão da categoria 5, item 5.5.
} 
Na realidade, o diretor é chefe dos agentes penitenciários, porém os ASPs são funcionários públicos concursados que gozam de estabilidade: já o diretor ocupa um cargo por indicação, do qual pode ser deposto a qualquer tempo. O diretor é escolhido pelo Secretário da Administração Penitenciária e com certa frequência são agentes penitenciários de carreira, com diploma de curso superior.

O fato dos ASPs terem uma situação mais confortável, por contarem com a segurança da estabilidade do serviço público, e o diretor ter que se preocupar em manter-se na função, é um fator que pode incentivar este último a esconder o que ocorre de ilegal na unidade sob sua responsabilidade, em uma tentativa de evitar o risco de perder o cargo.

Apenas um dos entrevistados abordou, explicitamente, a questão do poder existente entre o diretor e os ASPs. Porém este elemento merece receber maior destaque em sede de discussão dos dados em uma pesquisa qualitativa como esta.

A literatura coloca os agentes penitenciários em uma posição intermediária e conflitante entre fazer com que as ordens do diretor sejam cumpridas pelos presos e, ao mesmo tempo, levar aos diretores as reinvindicações dos presos. É como se os ASPs fossem os mediadores e negociadores desta relação entre o preso e o diretor ${ }^{336}$.

De acordo com o entrevistado que destacou o elemento de poder, os diretores acabam concedendo muito poder aos agentes para que consigam administrar o dia a dia da unidade. O exemplo dado pelo entrevistado é de que os diretores optam por não cancelar e nem mesmo apurar uma falta grave reportada por um agente para não desmoralizá-lo perante o preso. Deste modo, em nome da manutenção da disciplina, considera melhor manter a falta grave e a punição administrativamente aplicada. Essa postura adotada pelo diretor é um fator que aumenta o poder dos ASPs, uma vez que suas denúncias de faltas graves são chanceladas pelo diretor sem nem mesmo passar por uma apuração ${ }^{337}$.

Neste sentido, os ASPs acabam tendo o poder de criar regras para o funcionamento da unidade, regras, inclusive, que não estão previstas no regulamento. A pesquisa de CASTRO E SILVA ${ }^{338}$ revela que existe uma prática de negociação informal entre os agentes e os presos. Se o diretor aceita tudo o que os ASPs reportam a ele sem maiores questionamentos, este poder de negociação dos ASPs é elevado.

\footnotetext{
${ }^{336}$ GOFFMAN, Erving. Op. cit.; THOMPSON, Augusto. Op. cit.

${ }^{337}$ Este tema dialoga com o discutido na categoria 3, item 5.3.

${ }^{338}$ CASTRO E Silva, Anderson Moraes. Op. cit.
} 
KAUFFMAN aborda o código de ética informal que rege as relações entre ASPs e parece que a conduta do diretor em aceitar o que o ASP fala em detrimento do que foi narrado pelo preso, sem realizar nenhum esforço de apuração, dialoga com duas dessas normas, a quatro e a seis. A norma quatro estabelece a proibição de deixar um colega ASP em uma posição constrangedora na frente de um preso ${ }^{339}$. A razão de ser dessa regra é não deixar o agente em posição vulnerável perante os presos. Um agente não pode ser criticado na frente dos presos, mesmo que esteja agindo de modo incorreto ou que o outro agente discorde. A norma de número seis estabelece que as sanções impostas por um ASP a um preso devem ser sempre apoiadas e respaldadas pelos demais agentes.

Desta forma, parece que o código de conduta identificado por KAUFFMAN também se aplica na relação entre diretor e ASP e não apenas na relação entre ASPs. Pode-se inferir que há uma oposição entre o grupo dos presos de um lado e de outro o diretor e os agentes. Sendo assim, o diretor também não pode romper com as regras de conduta para não fortalecer o grupo de presos e também para não perder o apoio dos agentes, o que é fundamental para que se mantenha no cargo. Esse aspecto está em consonância com o apresentado por alguns juízes entrevistados que disseram perceber uma relação de parceria entre o diretor e os agentes penitenciários.

Com base no discutido acima, torna-se interessante analisar que todos os entrevistados percebem o diretor como sendo o responsável por fiscalizar as condutas dos ASPs, porém não houve unanimidade quanto à percepção se de fato ele cumpre ou não tal papel. Pode-se perceber que houve divergência quanto à frequência da ocorrência de atos considerados irregulares por agentes penitenciários. Como será visto na categoria 5, a maioria dos juízes entende que são poucos os ASPs que cometem atos de improbidade e, mais do que isso, afirmam que são poucos os casos que chegam ao conhecimento do Poder Judiciário.

Ora, se o Judiciário percebe o diretor como principal responsável por fiscalizar as condutas praticadas por agentes e, ao mesmo tempo, entende que são poucos os casos em que os diretores realizam denúncias contra os ASPs, faz sentido os juízes terem expressado percepção divergente quanto ao fato dos diretores estarem, ou não, realizando sua tarefa de fiscalização.

${ }^{339}$ KAUfFMAN, Kelsey. Op. cit. 


\subsection{Categoria 5: Probidade dos ASPs}

Nesta categoria, os temas discutidos serão divididos em cinco itens: improbidade, denúncias, motivação, poder e imagem perante a categoria dos ASPs e perante os presos.

\subsubsection{Improbidade}

A visão apresentada pelo Poder Judiciário é de que atos de corrupção e de violência não são comuns entre agentes penitenciários, sendo restritos à minoria ${ }^{340}$.

Interessante destacar aqui a fala de um dos entrevistados de que a existência da corrupção e da violência está relacionada, diretamente, com a postura adotada pelo diretor da unidade. Esta postura determina a maneira de atuação dos ASPs. A relação entre o diretor e os agentes penitenciários foi discutida na categoria 4 com mais detalhes, porém este aspecto é fundamental para a compreensão da existência dos atos de improbidade.

A percepção do Poder Judiciário de que, dentre os agentes penitenciários, são poucos os que cometem irregularidades, sendo a maioria composta por ASPs que seguem as regras e as leis, destoa radicalmente da literatura, que apresenta as negociações informais - que podem chegar até a aplicação de castigos físicos - e o fato dos ASPs não seguirem os trâmites oficiais em caso de faltas graves cometidas pelos presos como fatores fundamentais do universo do agente penitenciário e estruturante das relações no cárcere ${ }^{341}$.

Kauffman assevera em sua obra que não sabe afirmar se a prisão é de fato uma escola do crime; mas, com certeza, é uma escola da violência e da corrupção moral.

O Poder Judiciário parece discordar desta percepção. Mas cabe uma discussão de conceitos. Os juízes abordaram a existência da corrupção e da violência. A literatura muito se debruça sobre uma grande gama de outras irregularidades e ilegalidades que não se configuram como corrupção e nem como violência.

\footnotetext{
${ }^{340}$ Para um dos entrevistados está ocorrendo uma mudança de cultura na carreira de agente penitenciário no que diz respeito à tolerância a abusos, mas ainda está longe do ideal. Este entrevistado traçou um paralelo entre a carreira de agente penitenciário e a do policial civil, sendo que, para ele, a Polícia Civil tem uma cultura de tolerância a abusos maior do que a carreira do agente penitenciário.

${ }^{341}$ Castro e Silva, Anderson Moraes de. Op. cit. Moraes, Pedro Rodolfo Bodê de. Op. cit. Taets, Adriana Rezende Faria. Op. cit. VARELlA, Drauzio. Carcereiros. São Paulo: Companhia das Letras, 2012.
} 
Corrupção pressupõe o recebimento de vantagem indevida ${ }^{342}$ e a violência referida pelo Poder Judiciário é a física, que envolve infligir agressões corporais aos presos. Negociações informais de outras ordens, segundo a literatura, norteiam o cotidiano prisional, como, por exemplo, dar início a um procedimento de falta grave. O ASP, segundo a literatura acadêmica, opta por não fazê-lo em diversas situações para não “atrasar” a vida do preso, para não ficar mal visto perante os colegas por não ter dado conta de controlar a situação de outra forma etc.

Ademais, com o fortalecimento das facções criminosas, as agressões físicas praticadas por agentes realmente deixaram de fazer parte do cotidiano prisional, de acordo com a literatura específica que estudou o $\mathrm{PCC}^{343}$, mas atos de corrupção passaram a ser mais frequentes. O que não significa dizer que não sejam restrito a uma minoria.

O fato do Poder Judiciário perceber os agentes penitenciários como pouco corruptos e pouco violentos têm implicações na credibilidade que os juízes conferem aos depoimentos prestados pelos ASPs nos procedimentos judiciais. Tenderão os magistrados a crer na lisura das condutas relatadas pelo agente.

Adicionalmente, alguns juízes entrevistados falaram que o sistema busca excluir os corruptos e também que atos de improbidade são apurados pela corregedoria. Poder-se-ia discutir o grau de rigidez que os julgadores adotariam nessas situações em razão da percepção que têm dos agentes penitenciários. Poderiam ser rígidos neste julgamento para contribuir para a expulsão destes do sistema, ou poderiam ser mais ponderados, por considerarem que apenas uma minoria é corrupta, e necessitarem de mais provas para formarem seu convencimento para embasar a condenação.

\footnotetext{
${ }^{342}$ Art. 317 do Código Penal: Corrupção passiva - Solicitar ou receber, para si ou para outrem, direta ou indiretamente, ainda que fora da função ou antes de assumi-la, mas em razão dela, vantagem indevida, ou aceitar promessa de tal vantagem: Pena - reclusão, de 2 (dois) a 12 (doze) anos, e multa. § $1^{\circ}$ - A pena é aumentada de um terço, se, em consequência da vantagem ou promessa, o funcionário retarda ou deixa de praticar qualquer ato de ofício ou o pratica infringindo dever funcional. § $2^{\circ}$ - Se o funcionário pratica, deixa de praticar ou retarda ato de ofício, com infração de dever funcional, cedendo a pedido ou influência de outrem: Pena - detenção, de três meses a um ano, ou multa.

${ }^{343}$ DIAS, Camila Caldeira Nunes. Da guerra à gestão: a trajetória do Primeiro Comando da Capital (PCC) nas prisões de São Paulo. Revista Percurso. Sociedade, Natureza e Cultura. Curitiba, UniCuritiba, ano VIII, n. 10, v. 02, p. 79-96, 2009. TAETS, Adriana Rezende Faria. Op. cit.
} 


\subsubsection{Denúncias}

A imagem que o Poder Judiciário tem é de que são realizadas poucas denúncias sobre irregularidades cometidas por agentes ${ }^{344}$. Os presos e os demais ASPs raramente denunciam, talvez por medo de sofrerem represálias, segundo os entrevistados.

Quando as denúncias são feitas, elas não apresentam elementos suficientes para se chegar à autoria e punir o responsável. Sendo assim, o Poder Judiciário sabe que tem agentes que estão facilitando a entrada de, por exemplo, celulares nas unidades prisionais, mas não sabem quem é o responsável e por isso não podem aplicar a sanção devida ${ }^{345}$.

Um entrevistado disse que os advogados da FUNAP apresentam denúncias de irregularidades cometidas por agentes, já que são bastante combativos na defesa dos direitos dos presos.

Para um dos entrevistados, práticas de tortura ${ }^{346}$ provavelmente não ocorrem, o que chama atenção devido à contradição com a grande quantidade de denúncias de tortura e maus tratos no sistema prisional que são constatadas por órgãos da ONU e por organizações não governamentais ${ }^{347}$. Por exemplo, de acordo com o relatório elaborado pelo Subcomitê de Prevenção à Tortura da ONU, que se baseou na visita realizada em setembro de 2011 ao Brasil, mais especificamente a São Paulo, Rio de Janeiro, Espírito Santo e Goiás, a violência física contra os presos - que pode ser caracterizada como tortura e maus tratos - ainda ocorre com frequência ${ }^{348}$.

\footnotetext{
${ }^{344}$ Esse tema já foi objeto de discussão na categoria 2, item 5.2.

${ }^{345}$ Neste exemplo dado de celular dentro da penitenciária, o procedimento legal de apuração dá-se em âmbito administrativo. Além disso, pode ser aberto inquérito policial e o Poder Judiciário poderia, apenas, requisitar a instauração de um inquérito.

${ }^{346}$ Tortura está sendo utilizada aqui no conceito de infligir grave sofrimento físico e mental por meio de agressões físicas. Não se está trabalhando com o conceito mais amplo de tortura, que inclui condições físicas da unidade que sejam especialmente degradantes e desumanas.

${ }^{347}$ Vide PASTORAL CARCERÁRIA DE SÃO PAULO. Relatório sobre Tortura: uma experiência de monitoramento dos locais de detenção para prevenção da tortura. Publicado em: 2010. Disponível em: <http://carceraria.org.br/wp-content/uploads/2012/10/Relatorio_tortura_revisado1.pdf>. Acesso em: 4 jan. 2012._Instituto Terra, Trabalho e Cidadania e Pastoral Carcerária. Tecer Justiça. Presas e presos provisórios da cidade de São Paulo. Pesquisa publicada em: 2012. Disponível em: $<$ http://www.ittc.org.br/web/rel_tecer_justica_net.pdf>. Acesso em: 17 jul. 2012.

348 Subcomitê de Prevenção da TORTURA e outros Tratamentos ou Penas Cruéis, Desumanos ou DEgRADANTES DA ONU. Relatório sobre a visita ao Brasil do Subcomitê de Prevenção da Tortura e outros Tratamentos ou Penas Cruéis, Desumanos ou Degradantes. Relatório Publicado em: fev. 2012. Disponível em: <www.onu.org.br/img/2012/07/relatorio_SPT_2012.pdf>. Acesso em: 17 jul. 2012. CONECTAS DIREITOS HUMANOS. ONU visita Brasil para avaliar situação de tortura e maus-tratos no país. 21 set. 2011. Disponível em: <http://www.conectas.org/artigo-1/onu-visitabrasil-para-avaliar-situacao-de-tortura-e-maus-tratos-no-pais-2 . Acesso em: 26 dez. 2012.
} 
O fato de os agentes penitenciários não denunciarem seus colegas parece dialogar com o código de ética informal existente para regular as relações entre os ASPs, apresentada por KAUfFMAN. Todas as normas demonstram um sistema de solidariedade entre os agentes, mas a norma número três, não delatar, é específica e aplica-se à categoria em discussão. Esta regra implica não apenas não realizar a denúncia contra um colega, mas também não cooperar em uma investigação e não testemunhar contra um ASP.

\subsubsection{Motivação}

Na visão do Poder Judiciário as principais razões para a existência de corrupção por parte dos agentes é a presença das facções criminosas ${ }^{349}$ e o fato dos ASPs estarem em contato próximo com criminosos. Além, é claro, da dificuldade desses casos serem denunciados e apurados, como discutido no item acima.

Para os entrevistados, a facção criminosa corrompe o funcionário, seja pela imposição do medo, por meio de ameaças ou por ter dinheiro a oferecer. O fato de os ASPs terem salários baixos também é um facilitador, de acordo com a percepção do Poder Judiciário.

A questão da organização dos presos em facções é apresentada na literatura como um fator de aumento da corrupção entre os funcionários, ao mesmo tempo em que estaria associada à redução da prática de agressões físicas. Se por um lado, com o fortalecimento das facções criminosas, os presos conseguiram fazer frente às agressões físicas cometidas pelos agentes penitenciários, eles também conseguiram ter mais força para mobilizar os ASPs para realizarem ações irregulares que possam lhes favorecer, como permitir a entrada de celular e drogas nas unidades ${ }^{350}$, conforme já explorado acima. De acordo com Fernando Salla,

é necessário aprofundar a reflexão sobre o papel da corrupção na dinâmica do sistema penitenciário, uma vez que é graças a ela que os serviços se mantêm ineficazes, ao mesmo tempo em que é por ela que se viabiliza a formação e o empoderamento dos grupos criminosos organizados, ao favorecer as fugas, a

\footnotetext{
${ }^{349} \mathrm{O}$ tema das facções criminosas será mais detidamente analisado na categoria 10, item 5.10.

350 DiAs, Camila Caldeira Nunes. Violência, PCC e prevenção do crime. Op. cit. DiAs, Camila Caldeira Nunes. Da guerra à gestão. Op. cit.
} 
entrada de armas, drogas, celulares e tornando os ambientes prisionais de alto risco para presos e funcionários. ${ }^{351}$

Para TAETS, a presença do PCC ${ }^{352}$ nas unidades prisionais altera o cenário em que os guardas detinham o controle da unidade prisional e que tal cenário passa a ser compartilhado entre os agentes e as facções ${ }^{353}$.

Um juiz entrevistado apresentou uma percepção de que, ainda, alguns ASPs desrespeitam os direitos dos presos por "ruindade".

CASTRO E SiLVA observa que há uma alteração no perfil dos agentes penitenciários, os mais antigos são conhecidos como “cascudos” e são mais “durões” e violentos, ao passo que os mais novos são mais corruptos ${ }^{354}$. Um juiz apresentou percepção semelhante sobre os agentes mais antigos na carreira, segundo ele, os ASPs da "velha guarda” não são nada "humanistas”, o que dá a entender que praticam mais agressões físicas do que os mais novos.

TAETS $^{355}$ também aborda o elemento de diferenciação existente entre os agentes penitenciários mais antigos e mais novos, porém, de acordo com ela, a diferenciação reside no conhecimento acumulado. Como discutido na categoria 1, os ASPs valorizam muito o conhecimento prático, que só é possível de ser adquirido com a experiência na profissão. Segundo a autora, os agentes penitenciários mais antigos são conhecidos como “dinos” alusão a “dinossauro”, e os mais novos são logo advertidos, desde o curso preparatório, a não seguirem o que os “dinos” falam, pois eles “possuem muita experiência e muito 'ranço' de cadeia”’356.

A pesquisadora analisou este aspecto e afirmou que os “dinos” são perigosos para o sistema penitenciário, pois não seguem as ordens que vêm de cima, e sim “decidem sozinhos a rotina e os rumos do cotidiano da instituição ${ }^{357}$. Isso pode ter um impacto na questão da prática dos atos de improbidade.

\footnotetext{
${ }^{351}$ SALLA, Fernando. De Montoro a Lembo: as políticas penitenciárias de São Paulo. Revista Brasileira de Segurança Pública, São Paulo, n. 1, v. 1, p. 72-90, 2007. Disponível em: <http://revista.forumseguranca.org.br/index.php/rbsp/article/view/8/5>. Acesso em: 25 dez. 2012.

${ }^{352}$ Primeiro Comando da Capital.

353 TAETS, Adriana Rezende Faria. Op. cit.

${ }^{354}$ CAStro E Silva, Anderson Moraes de. Op. cit.

355 TAETS, Adriana Rezende Faria. Op. cit.

${ }^{356}$ Idem, p. 145.

${ }^{357}$ Idem, p. 146.
} 
DrAUZio VARELLA, médico voluntário no sistema prisional paulista desde a década de 1980, escreveu um livro em que relata histórias vivenciadas por agentes penitenciários. Segundo ele, os novatos não têm conhecimento do funcionamento da cadeia, sendo que este conhecimento - adquirido somente pela prática - é valorizado:

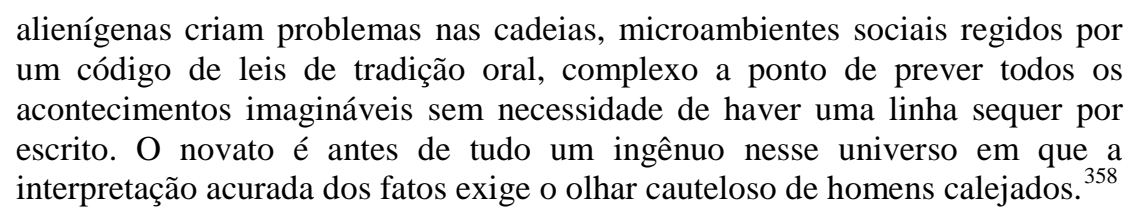

\subsubsection{Poder}

Apenas um dos entrevistados apontou o poder como elemento fundamental para a compreensão da questão da improbidade entre os agentes penitenciários. Para ele, é exatamente nas relações de poder que os agentes praticam atos arbitrários, como registrar faltas graves, que não ocorreram, ou a imposição de violência ${ }^{359}$. Segundo a percepção apresentada, mesmo estando em número reduzido se comparado aos presos, os ASPs conseguem exercer o poder ao gerar situações em que fiquem em superioridade numérica.

A questão do poder é central para a discussão da improbidade. O fato dos agentes expressarem seu poder a partir de práticas irregulares deve fazer parte dessa discussão. KAUFFMAN $^{360}$ apresenta em sua obra seis formas de expressão do poder do ASP perante o preso, e apenas uma delas, a autoridade, não implica práticas irregulares; as demais podem ser interpretadas como formas ilegais de imposição do poder.

\subsubsection{Imagem perante a categoria e perante os presos}

De acordo com o Poder Judiciário, o agente penitenciário corrupto fica logo conhecido e os colegas perdem o respeito que nutriam por ele. TAETS faz uma análise exatamente no mesmo sentido, mas, segundo ela, as agentes penitenciárias corruptas e

\footnotetext{
${ }^{358}$ VARELLA, Drauzio. Op. cit., p. 15.

${ }^{359}$ Elemento discutido na categoria 3, item 5.3.

${ }^{360}$ KAUFFMAN, Kelsey. Op. cit.
} 
violentas ficam mal vistas pelas presas, o que pode acarretar, inclusive, punições por parte da facção atuante na unidade prisional. Segundo ela: “A guarda justa não precisa temer. Quem teme é a guarda violenta e corrupta: aquelas que de alguma maneira abusam do poder, ou então, são consideradas, na visão do coletivo de presas, tão criminosas como as presas e por isso deveriam elas estar reclusas também”361_362.

Um dos entrevistados afirmou que a estrutura busca retirar os ASPs corruptos da carreira, o que está em perfeita consonância com o apresentado neste item. Ser mal visto por colegas e, mais forte do que isso, pelos presos, pode ser entendido como mais um movimento da estrutura rumo à exclusão dos funcionários corruptos.

De tudo acima exposto, extrai-se que a percepção do Poder Judiciário na temática da probidade dos agentes penitenciários é de que apenas uma minoria é corrupta e comete agressões físicas. A literatura que focalizou temas pertinentes a este ponto relata a existência de uma série de outras irregularidades e ilegalidades cometidas pelos ASPs na administração cotidiana da prisão, que não se configuram nem como corrupção e nem como violência física.

As principais motivações para o cometimento destes atos ilegais, de acordo com o Poder Judiciário, são a presença das facções criminosas e a proximidade entre ASPs e criminosos. Ademais, os entrevistados expressaram ter a percepção de que os agentes corruptos são mal vistos por seus colegas.

\subsection{Categoria 6: Vulnerabilidade e segurança do ASP no exercício da sua} profissão

A percepção do Poder Judiciário é de que o trabalho dos agentes é permeado por inseguranças e fatores que aumentam a sua vulnerabilidade. Os principais fatores que

\footnotetext{
361 TAETS, Adriana Rezende Faria. Op. cit., p. 110.

${ }^{362}$ Não se pode deixar de complementar que existem atos de corrupção e violência que são cometidos em acordo entre ASPs e facção. Estes casos provavelmente não geram punições aos ASPs por parte das facções.
} 
compõem tal percepção são a presença das facções criminosas, as superlotações dos presídios e questões daí decorrentes, como maiores chances de contaminação por doenças e risco de violência, como as rebeliões.

O fato de os ASPs serem vítimas de constantes ameaças, de acordo com o Judiciário, aumenta o medo vivenciado por eles no dia a dia ${ }^{363}$, enfatizando o sentimento de insegurança e vulnerabilidade.

Esse elemento ajuda a compreender o apresentado por KAUFFMAN. As regras de condutas informais que regem as relações dos ASPs entre si fundamentam-se na solidariedade entre os membros do grupo. Essas regras de conduta têm como base a percepção dos agentes de que precisam dos colegas para realizar seu trabalho e, mais importante do que isso, precisam de apoio para sobreviver. Todas essas normas têm como pano de fundo o dever de auxiliar os colegas que possam estar em perigo ${ }^{364}$.

No mesmo sentido, VARELLA cita uma fala de um ASP: "no dia a dia a gente podia se desentender, falar mal do outro, não ir com a cara dele, mas na hora do perigo chegávamos junto. Era nós na fita, para o que Deus desse e o diabo mandasse”365.

A facção aparece como fator que eleva o risco da atividade dos agentes, uma vez que se estabelece uma competição pelo poder. Além disso, a organização dos presos facilita que se crie uma situação de violência ou rebelião, que poderia atentar contra a integridade física dos ASPs ${ }^{366}$.

CAmila DiAs, socióloga e pesquisadora de assuntos relacionados ao sistema prisional e ao PCC, afirma que todos os conflitos que ocorrem no cotidiano carcerário, nas cadeias “comandadas” pelo PCC, têm esta facção como instância de regulação e mediação de conflitos - conflitos estes que envolvem a população carcerária, as visitas e os funcionários. Segundo ela, pelo menos 90\% das unidades prisionais do Estado de São Paulo são comandadas por esta facção. Os integrantes do PCC exercem o controle da unidade prisional, solucionando os conflitos e dominando as atividades relativas ao comércio dentro da unidade, o que inclui a entrada e distribuição de entorpecentes ${ }^{367}$.

\footnotetext{
363 Questões relacionadas ao medo serão objeto de discussão na categoria 9, item 5.9.

${ }^{364}$ KAUfFMAN, Kelsey. Op. cit., p. 85-117.

365 VARELLA, Drauzio. Op. cit., p. 103.

366 Questões ligadas ao impacto que as facções criminosas exercem na profissão do agente penitenciário serão objeto de discussão mais detida da categoria 10, item 5.10.

${ }^{367}$ DIAS, Camila Caldeira Nunes. Da guerra à gestão. Op. cit.
} 
Um dos juízes apresentou uma percepção um pouco divergente dos demais magistrados, porém no mesmo sentido da literatura discutida. Para ele, a presença da facção tem um efeito ambíguo sobre os agentes penitenciários ${ }^{368}$ : por um lado, o dia a dia torna-se mais tranquilo e menos tenso, por outro, a atividade profissional torna-se mais perigosa. Isso porque a liderança dos presos faz com que a disciplina seja cumprida e a unidade prisional fique "calma”, o que facilita o trabalho cotidiano do agente. Mas o perigo de sofrer alguma represália aumenta em decorrência da presença das facções fora dos presídios, que realizam constantes ameaças.

No mesmo sentido, TAETS afirma que as decisões tomadas pelos agentes penitenciários não se baseiam apenas na análise do contexto imediato, mas também levam em consideração as ameaças - por vezes endereçadas às suas famílias - que recebem de membros das facções pelo fato das facções estarem presentes também fora dos presídios.

O seguinte trecho extraído da dissertação da pesquisadora demonstra que as agentes penitenciárias alteram sua postura dentro das unidades em razão destes fatores produtores de insegurança, citando especificamente um caso em que dados familiares de uma agente eram conhecidos em detalhes por presas:

\begin{abstract}
Ao tomar conhecimento de que as presas sabiam de detalhes íntimos da rotina de sua família [da ASP] fora do presídio, uma guarda com quem conversei afirmou que mudou de postura dentro do presídio, e passou a ser menos exigente com as presas, menos dura, mesmo que estivesse no seu direito, ou seja, mesmo que estivesse apenas sendo ‘justa', apenas cumprindo as regras. ${ }^{369}$
\end{abstract}

A percepção do Poder Judiciário, no que diz respeito aos fatores de insegurança e vulnerabilidade dos ASPs, está em perfeita consonância com o apresentado pela literatura acadêmica. O fato dos juízes perceberem o trabalho dos ASPs como perigoso e perceberem que estes estão em uma posição de vulnerabilidade impacta diretamente a forma como tomam decisões nos processos que lhes chegam. Este elemento foi discutido na categoria 2, quando se falou do respaldo que o juiz deve dar ao ASP, sendo rígido no julgamento de faltas graves, em especial, naquelas em que os agentes são as vítimas.

\footnotetext{
${ }^{368}$ Os demais entrevistados que abordaram este tema ressaltaram apenas impactos negativos relacionados à presença das facções criminosas nas unidades prisionais para o trabalho do ASP.

${ }^{369}$ TAETS, Adriana Rezende Faria. Op. cit., p. 171.
} 
Ademais, a expressão da percepção dos juízes de que a atividade desempenhada pelos ASPs é de risco, demonstra, mais uma vez, que o Poder Judiciário valoriza positivamente o trabalho desta classe profissional. De acordo com essa interpretação, os juízes percebem que o trabalho do agente é perigoso, e que eles estão arriscando-se para executá-lo.

\subsection{Categoria 7: Valorização, por parte do Poder Judiciário, do depoimento do} ASP

No que diz respeito à valorização do depoimento do ASP em processos judiciais em especial nos procedimento de apuração de falta grave - a posição dos entrevistados ficou dividida ${ }^{370}$. Para uma parcela, é grande o valor atribuído à palavra do agente - posto que funcionário público - enquanto para outra, a presunção de veracidade é relativa, sendo possível que o preso apresente prova contrária ao alegado. Existem ainda aqueles entrevistados que disseram não haver qualquer presunção que fortaleça o depoimento dos ASPs. Para estes, as alegações feitas pelos agentes devem ser provadas.

Interessante observar a divergência de posicionamentos sobre a valorização da palavra do ASP no processo judicial. Saber qual a posição costumeiramente adotada pelo juiz responsável pela unidade prisional em que trabalha deve produzir impactos na postura dos agentes penitenciários.

O fato de saberem se sua palavra será questionada ou se sua versão será aceita como verdadeira pode resultar em efeitos significativos na forma pela qual os agentes recorrem aos procedimentos legais.

A frequência com que optam por adotar procedimentos legais pode ser influenciada pela valorização que o Poder Judiciário dá ao seu depoimento. Além disso, também podem perceber padrões e fazer escolhas baseadas nestas percepções. Assim, podem escolher quais situações lhes são vantajosas para registrar como falta. E, mais do que isso, o conhecimento desses padrões de conduta dos julgadores pode nortear a instrução destes procedimentos para que a sua versão seja chancelada pelo Poder Judiciário.

\footnotetext{
${ }^{370}$ Elementos relativos à valorização da palavra do ASP por parte do Poder Judiciário já foram discutidos nas categorias 2 e 6 .
} 
Como as faltas graves são uma forma de relação intensa e frequente entre o Poder Judiciário e o ASP, de acordo com a percepção dos próprios juízes ${ }^{371}$, a compreensão da maneira pela qual elas são analisadas é importante para se refletir sobre as consequências das percepções do Judiciário acerca do ASP.

Em suma, a forma como o Poder Judiciário valora a palavra do agente pode produzir efeitos substanciais na maneira de agir dos ASPs, impactando na frequência e na forma de acesso ao Judiciário utilizada pelos agentes. Sabendo-se que a sua palavra será tida como verdadeira, se será admitida prova em contrário ou se caberá provar o alegado, o ASP pode optar por lançar mão deste recurso como forma de auxiliá-lo a manter a disciplina na unidade. Pode, assim, pensar estrategicamente o acesso ao Judiciário para alcançar determinados objetivos.

Neste sentido, é extremamente importante que os magistrados tenham a consciência do papel fundamental que desempenham no sistema carcerário e do impacto que suas percepções - especialmente quando influenciam suas decisões - podem produzir na dinâmica carcerária e nas complexas relações que se estabelecem dentro dos muros. Ou seja, mesmo permeando pouco a vida cotidiana carcerária, o Poder Judiciário exerce uma influência direta sobre as relações estabelecidas nos presídios.

\subsection{Categoria 8: Condições de trabalho do ASP}

A visão do Poder Judiciário é unânime no sentido de considerar as condições de trabalho dos agentes penitenciários precárias. Os principais elementos destacados se dividem em dois grupos: o primeiro refere-se às condições da unidade prisional; o segundo, às condições relativas à estrutura da carreira dos agentes penitenciários. A discussão e interpretação dos dados que dizem respeito às condições de trabalho dos ASPs será distribuída nestes dois tópicos.

\footnotetext{
${ }^{371}$ Como discutido no item Contato entre ASP e Judiciário, da categoria 2, item 5.2.1.
} 


\title{
5.8.1 Condições da unidade prisional
}

O Poder Judiciário percebe as condições das unidades prisionais como precárias, sobretudo em função da superlotação, excesso de demanda, falta de estrutura e insalubridade.

Tal visão está em perfeita consonância com o apontado pela literatura. ARLINDO DA SILVA LOURENÇO observou a estafa de agentes penitenciários soterrados em tanta demanda de trabalho que, por vezes, são responsáveis por atender às demandas de dois pavilhões simultaneamente.

\begin{abstract}
Não foram poucas as vezes que os vimos sozinhos [ASPs], impelidos a negociar com os prisioneiros para que o ambiente não se tornasse mais tenso. Os prisioneiros, detidos nos pavilhões, chamam constantemente pelos funcionários que, através do visor do portão de acesso ao pavilhão, os atendem, enquanto possível. Como alguns funcionários têm que atender às solicitações de presos de dois pavilhões, além de abrir e fechar as portas das gaiolas para outros presos ou funcionários, as tarefas nesse setor tornam-se extenuantes em alguns momentos do dia. Alguns funcionários se permitiam fingir que não escutavam as solicitações dos presos nos pavilhões e, assim, conseguiam alguns segundos para descansar. ${ }^{372}$
\end{abstract}

LOURENÇO também descreve uma das penitenciárias em que realizou suas observações participantes - em Guarulhos, na grande São Paulo - como tendo as paredes descascadas em decorrência da umidade; as grades de ferro corroídas pela ferrugem; a luminosidade decrescente conforme se adentra os corredores da prisão e o ar cada vez mais rarefeito. Mas o que mais chama atenção no relato trazido pelo autor é a umidade que afeta a temperatura. Segundo ele, mesmo em dias de verão e de calor, é necessário usar agasalho para lidar com a sensação de frio ${ }^{373}$.

Sobre a insalubridade, também é vasta a literatura que identifica as prisões como locais de aumento da probabilidade de se contrair doenças. A expectativa de vida dos agentes penitenciários é mais baixa do que do restante da população, exatamente por

\footnotetext{
${ }^{372}$ LOURENÇO, Arlindo da Silva. Op. cit., p. 178.

${ }^{373}$ Idem, p. 129 e 136.
} 
passarem horas fechados nestes ambientes fétidos, mal arejados, úmidos e com grande concentração de pessoas por metro quadrado.

A expectativa de vida dos ASPs no Estado de São Paulo é menor do que a população em geral. Um estudo de 1998, realizado por LouRENÇO, concluiu que 73\% dos falecimentos de agentes penitenciários deu-se entre 36 e 55 anos de idade, ao passo que a expectativa de vida da população em geral para o período era calculada em 67 anos. Em 1999, o número de falecimentos de ASPs nesta faixa etária chegou a 78,5\% ${ }^{374}$. Essa diferença brutal é atribuída especialmente às condições deficitárias de infraestrutura das unidades prisionais, às longas jornadas de trabalho e ao estresse advindo do exercício profissional $^{375}$. De acordo com LOURENÇO ${ }^{376}$ e TAETS $^{377}$, as principais doenças contraídas pelos ASPs em razão dos fatores associados às péssimas condições de trabalho são: diabetes, hipertensão, estresse e depressão.

KAUFFMAN também identifica impactos na saúde física dos agentes prisionais decorrentes de sua atividade profissional. Segundo ela, além dos ferimentos provocados por presos, os ASPs relataram terem adquirido problemas de pressão alta, problemas cardíacos, dores de cabeça intensas e vista embaçada ${ }^{378}$.

A falta de recursos humanos e materiais percebida pelo Judiciário também está expressa na literatura. Autores apontam que, para assegurar a realização do mínimo necessário de tarefas, é essencial que a administração da unidade prisional conte com os serviços prestados por presos em diversas áreas, como cozinha, faxina, escola, biblioteca, enfermaria e até em atividades administrativo-burocráticas.

Segundo THOMPSON, este elemento é central para a compreensão da relação que se estabelece entre presos e agentes penitenciários ${ }^{379}{ }^{380}$. Passa-se a criar um relacionamento diferente entre os ASPs e os presos que exercem estas funções, de modo que a literatura identifica uma relação de troca, em especial de informações, entre estes sujeitos.

\footnotetext{
${ }^{374}$ LOURENÇO, Arlindo da Silva. Op. cit., p. 69-73. Vide também AGÊNCIA USP. Estudo aponta que expectativa de vida de agente penitenciário é de 45 anos em SP. Folha de São Paulo, Cotidiano, São Paulo, 22 nov. 2010. Disponível em: <http:/www1.folha.uol.com.br/cotidiano/834606-estudo-aponta-queexpectativa-de-vida-de-agente-penitenciario-e-de-45-anos-em-sp.shtml>. Acesso em: 25 dez. 2012.

${ }^{375}$ AGÊNCIA USP. Op. cit.

${ }^{376}$ Idem.

377 TAETS, Adriana Rezende Faria. Op. cit., p. 64.

${ }^{378}$ KaUfFMAN, Kelsey. Op. cit., p. 212-243.

379 ThOMPSON, Augusto. Op. cit., p. 51.

${ }^{380}$ Outros aspectos atinentes ao relacionamento estabelecido entre presos e ASPs já foi objeto de discussão da categoria 3, item 5.3.
} 
O trabalho do preso é, de acordo com CASTRO E SiLVA, essencial para que a cadeia continue equilibrada e é um fator gerador de cumplicidade, em razão da dependência e da convivência entre ASPs e presos ${ }^{381}$.

Os pesquisadores franceses Chauvenet, ORLiC e Benguigui identificaram a distribuição de trabalho e de tarefas para os presos como uma ferramenta importante de controle e disciplina por permitir que sejam estes postos de trabalho oferecidos como recompensa ou para garantir a cooperação dos presos, e também para evitar a formação de coalizões entre os encarcerados, uma vez que os ASPs podem escolher quem destacar para os postos de trabalho em função de seus objetivos estratégicos ${ }^{382}$.

Os dados oficiais deixam clara a falta de recursos humanos. Apenas a título de exemplo, cita-se a contratação de apenas 349 médicos clínicos gerais para atender os quase 550 mil presos em todo o Brasil ${ }^{383}$, sendo que no Estado de São Paulo, para atender aproximadamente 12 mil mulheres presas, há apenas dois médicos ginecologistas ${ }^{384}$.

Segundo TAETS, a superlotação das unidades prisionais é um fator gerador de ansiedade para os ASPs. Para ela, “o que marca, então, o dia a dia na prisão é o improviso, assim o ASP deve ser capaz de criar soluções provisórias para a falta de estrutura que é típica da instituição na qual trabalha”385.

É uma importante reinvindicação da categoria dos agentes penitenciários a contratação de novos funcionários, em razão da superlotação. De acordo com o Diretor do Sindicato dos Funcionários do Sistema Prisional do Estado de São Paulo - SIFUSPESP Gilberto Machado, “estamos vivendo a precarização do trabalho no sistema prisional, que vem adoecendo a nossa categoria. A necessidade de novas contratações é fundamental e urgente" 386 .

Alguns aspectos emocionais também foram considerados como precarizantes pelo Judiciário. Os entrevistados consideram o fato do ambiente prisional ser muito "carregado" como um intensificador das condições ruins de trabalho dos ASPs. Foi levantado também

\footnotetext{
${ }^{381}$ CASTRO E Silva, Anderson Moraes de. Op. cit.

382 Chauvenet, Antoinette; OrLIC, Françoises; Benguigui, Georges. Op. cit., p. 17-33.

${ }^{383}$ MiNisTÉRIO DA JUSTIÇA. Todas UF’s. Referência 06/2012. Op. cit.

${ }^{384}$ MinistÉRIO DA JUSTIÇA. São Paulo-SP. Referência 06/2012. Op. cit.

385 TAETS, Adriana Rezende Faria. Op. cit., p. 55.

386 SIFUSPESP cobra condições de trabalho e saúde ao secretário da Gestão Pública. SIFUSPESP. 12 dez. 2012. Disponível em: <http://www.sifuspesp.org.br/index.php/materia-4/1661.html>. Acesso em: 25 dez. 2012.
} 
que alguns agentes levam os valores que estão dentro da prisão para fora do ambiente de trabalho.

TAETS considera que as doenças físicas e psicológicas são elementos essenciais a serem considerados para a compreensão dos agentes penitenciários. Segundo ela,

\begin{abstract}
Uma vez dentro do sistema prisional parece ser impossível não adoecer. Por um lado, Léo aponta para os colegas que adoeceram porque não souberam lidar com a dor do preso, agindo sempre de forma muito rígida e, por isso, foram se tornando violentos em suas relações pessoais e desenvolvendo diversos tipos de doenças físicas e mentais. Por outro, os guardas que se identificam de alguma forma com a dor dos presos e presas também adoecem, porque estes precisam enfrentar o sistema prisional. ${ }^{387}$
\end{abstract}

Esses e outro elementos relativos ao psicológico dos ASPs serão discutidos no próximo item, referente à categoria 9.

\title{
5.8.2 Estrutura da carreira do ASP
}

Sobre a estrutura da carreira, foi destacada, pelo Judiciário, a baixa remuneração dos ASPs como sendo um fator negativo no que toca às condições de trabalho.

Para o Judiciário, se os agentes fossem mais valorizados - o que se refletiria em maiores salários - ocorreriam em menor escala atos de corrupção ${ }^{388}$. Além disso, de acordo com a visão apresentada pelos entrevistados, se os ASPs fossem mais valorizados, seriam melhores profissionais ${ }^{389}$.

A literatura identifica que por serem baixos os salários pagos aos ASPs, eles optam por realizar trabalhos informais em seus dias de folga, os chamados "bicos"390_391. A realização de bicos é muito negativa para a saúde física e psicológica dos agentes, já que

\footnotetext{
387 TAETS, Adriana Rezende Faria. Op. cit., p. 140.

${ }^{388}$ Outros aspectos relacionados à improbidade dos agentes penitenciários foram discutido na categoria 5, item 5.5 .

${ }^{389}$ O aumento de salário e a melhor estruturação da carreira são reivindicações constantes da categoria profissional dos ASPs. São realizadas campanhas salariais pelo Sindicato dos Agentes Penitenciários. SIFUSPESP. Op. cit.

${ }^{390}$ LOURENÇO, Arlindo da Silva. Op. cit.

${ }^{391}$ No dia 27 de novembro de 2012 entrou em vigor, no Estado de São Paulo, a Lei Complementar 1.188, que torna legal, para policiais militares, o exercício de atividades remuneradas associadas à gestão de serviços públicos nos dias de folga, se exercidas em convênio com o Estado e municípios.
} 
eles acabam por não utilizar seus dias de descanso para diversão ou repouso. Em geral, os “bicos” realizados são atividades relativas à segurança, ou seja, são tarefas que exigem que os agentes estejam em constante estado de alerta, assim como durante o plantão na unidade prisional. Deste modo, os ASPs alcançam níveis de fadiga muito elevados, o que acaba por influenciar suas condições de saúde físicas e emocionais.

DRAUZIO VARELLA destaca exatamente esse elemento na sua obra sobre os agentes penitenciários. Segundo ele,

\begin{abstract}
viver em estado de alerta cria um clima de estresse generalizado que é inerente à atividade profissional. A necessidade de complementar o salário como segurança de lojas, supermercados, casas lotéricas, cassinos clandestinos e inferninhos aumenta sobremaneira a carga de trabalho, priva-os do sono regular, do lazer dos dias de folga, afasta-os do lar, do convívio com a família, e dá origem aos desacertos que explicam o grande número de casamentos desfeitos. ${ }^{392}$
\end{abstract}

A carreira de agente penitenciário é considerada como de caráter especial, o que justifica a existência do regime de turnos. Os turnos permitem dias completos de afastamento da realidade prisional como forma de cuidado da saúde dos funcionários ${ }^{393}$.

Contudo, ao contrário, TAETS ${ }^{394}$ e KAUFFMAN ${ }^{395}$ apresentam o fator salarial como uma das principais motivações para o ingresso na carreira de agente penitenciário. Segundo as pesquisas realizadas por elas, muitos agentes penitenciários se interessaram pela carreira por serem oferecidos salários maiores do que poderiam obter no mercado de trabalho dada a baixa qualificação. Para a qualificação exigida para prestar o concurso de ingresso na carreira, a média salarial é de um salário mínimo, sendo que o salário inicial do ASP é de aproximadamente R\$2.000,00.

O tema da estrutura da carreira do ASP é um dos temas centrais na pesquisa de SABAINI. De acordo com o autor, o salário de agente penitenciário é um grande atrativo nas cidades do interior do Estado de São Paulo, em que o custo de vida é mais baixo e a oferta de empregos é pequena. Por esse motivo, a família estimula os parentes a prestarem o concurso para obterem esse nível de renda ${ }^{396}$. Tal renda, considerada alta tendo em vista o

\footnotetext{
392 VARELLA, Drauzio. Op. cit., p. 104.

393 TAETS, Adriana Rezende Faria. Op. cit., p. 63.

${ }^{394}$ Idem.

395 KAUfFMAN, Kelsey. Op. cit.

${ }^{396}$ SABAINI, Raphael. Op. cit., p. 53.
} 
padrão dos empregos nas pequenas cidades e a qualificação exigida para ser ASP, tornamse ainda mais atrativa pelo fato dos agentes trabalharem apenas 15 dias por mês, em razão da carga horária de trabalho ser distribuída em turnos ${ }^{397}$.

Além do salário, a carreira de agente penitenciário possui outros atrativos inerentes às atividades públicas. SABAINI retrata esses outros elementos como atrativos para o ingresso e continuidade na carreira na pequena cidade de Itirapina, no interior do Estado de São Paulo. Segundo ele:

Para os padrões de uma cidade como Itirapina, os agentes penitenciários destacam-se socialmente adquirindo um padrão de vida superior ao da média da população itirapinense que não possui um parente trabalhando nas penitenciárias. Esses agentes, por sua vez, possuem acesso mais fácil para a obtenção de crédito no comércio local, além de ter a oportunidade de efetuar empréstimos e de financiar seu automóvel e sua casa própria. Já no único supermercado da cidade (...) os funcionários das cadeias possuem maiores facilidades para efetuar seu cadastro no crediário do estabelecimento, assim como também possuem cerca de cinco dias a mais nas compras a prazo em relação aos demais clientes. ${ }^{398}$

A estabilidade e a aposentadoria, bem como os demais benefícios, constituem incentivo ao ingresso e à manutenção na carreira, em que pese o altíssimo grau de insalubridade.

A estabilidade, conforme desenvolvido por SABAINI, permite que os ASPs obtenham facilidades de crédito junto a instituições financeiras ou estabelecimentos comerciais. O que constitui um fator de alto prestígio social.

Em razão dos impactos na saúde dos agentes penitenciários discutidos acima, é muito frequente que necessitem gozar de licenças de saúde, o que lhes é permitido em razão das garantias do serviço público ${ }^{399}$.

Vê-se que por um lado há uma percepção, por parte do Poder Judiciário e por parcela da literatura, de que os salários dos ASPs são baixos, o que gera diversas implicações, como dito acima. Porém, por outro lado, alguns autores identificam os salários e demais benefícios do serviço público como um atrativo da carreira. O que pode

\footnotetext{
${ }^{397}$ Idem, p. 123-124.

${ }^{398}$ Idem, p. 121-122.

${ }^{399}$ De acordo com LOURENÇO, aproximadamente 10\% dos ASPs afastam-se de suas funções por motivos de saúde. LourençO, Arlindo da Silva. Op. cit. AGÊNCIA USP. Op. cit.
} 
parecer um impasse, a princípio, na realidade pode indicar uma riqueza de elementos que se somam para a composição da realidade do mundo do ASP.

Os salários e os demais benefícios podem, de fato, ser um atrativo para o ingresso na carreira. Tais rendimentos podem ser vistos como altos quando sopesados com a qualificação exigida. Contudo, há pouca progressão no salário que, apesar de ser percebido como alto para o ingressante da carreira, depois se mostra insuficiente para a manutenção da família. Neste sentido, o regime de trabalho em plantões pode, sim, constituir-se em um elemento que incentive a procura por "bicos”.

Ademais, os desgastes emocionais e físicos da profissão do ASP são tão intensos que é difícil explicar porque mantêm-se na carreira mesmo sofrendo tanto. KAUFFMAN aborda este aspecto em sua pesquisa e, para ela, o poder e o prazer que exercer tal posição produz no ASP é uma das explicações, pois dificilmente estes profissionais encontrariam outro emprego em que pudessem dispor de tanto poder. Porém, outra explicação pode ser somada a esta: a das garantias trabalhistas estabelecidas pelas regras que regem o serviço público. A estabilidade pode ser um fator de incentivo à continuidade na carreira.

As percepções do Poder Judiciário apresentadas nos dois subtópicos acima produzem implicações importantes a serem discutidas. Estas visões influenciam a maneira pela qual a análise dos casos concretos, que chegam para serem julgados, é realizada pelo Poder Judiciário.

Os juízes das Varas de Execução Criminal têm o poder-dever de tomar providências para o adequado funcionamento das unidades prisionais, podendo, inclusive, promover ações de apuração de responsabilidade. Além disso, podem interditar as unidades prisionais que não estejam em condições dignas de trabalho para os agentes penitenciários e sem condições de custodiar presos. Estas atribuições lhes são conferidas pela Lei de Execuções Penais.

Ademais, o Judiciário é o órgão responsável por decidir sobre prisões e solturas. Neste sentido, tendo a percepção das condições físicas das unidades, os juízes podem optar por não determinar a prisão, sabendo o que a pessoa enfrentará durante a execução da pena 
ou, ainda mais grave, na fase da prisão provisória, e o impacto que a superlotação tem para os agentes penitenciários ${ }^{400}$.

Outro aspecto relevante diz respeito às decisões ajuizadas por agentes penitenciários em razão das péssimas condições de trabalho que enfrentam. Os julgadores podem ter a dimensão real do problema e considerá-la em suas decisões.

\subsection{Categoria 9: Fatores emocionais relacionados ao trabalho do ASP}

Os aspectos que dizem respeito aos fatores emocionais que apareceram nas entrevistas podem ser divididos em três subtemas: emoções, saúde mental e contaminação psicológica.

\subsubsection{Emoções}

O Poder Judiciário percebe a profissão dos agentes penitenciários como sendo permeada por tensões e medo.

A literatura que se debruçou sobre o tema apresenta a mesma visão. A presença do medo, da tensão e da ansiedade no ambiente prisional são as emoções mais destacadas por diversos pesquisadores ${ }^{401}$.

As pesquisas apresentam o medo como sendo constante no exercício profissional do ASP. Além de terem de ficar em constate estado de alerta, os agentes penitenciários sentem medo durante todo o tempo em que estão de plantão. E, com o advento das facções criminosas, o medo continua mesmo depois que deixam o ultimo portão na saída do trabalho $^{402}$.

\footnotetext{
${ }^{400}$ Apenas o juiz da Vara de Execução Criminal tem o dever de visitar unidades prisionais. Talvez se os demais juízes criminais conhecessem pessoalmente as instalações das prisões, as decisões de soltura ou não da prisão baseadas neste motivo fossem mais frequentes.

${ }^{401}$ Kauffman, Kelsey. Op. cit., p. 221-234. CAStro e Silva, Anderson Moraes de. Op. cit. Lourenço, Arlindo da Silva. Op. cit. MorAES, Pedro Rodolfo Bodê de. Op. cit. TAETS, Adriana Rezende Faria. Op. cit. Varella, Drauzio. Op. cit. ThOMPson, Augusto. Op. cit. ChiEs, Luiz Antônio Bogo et al. Op. cit.

402 TAETS, Adriana Rezende Faria. Op. cit.
} 
Um dos agentes penitenciários entrevistado por KAUFFMAN disse: "Eu tinha medo. Todos os dias eu tinha medo de ir para o trabalho. Eu realmente tinha medo. Eu ficava petrificado" 403 .

Contudo, segundo KAUFFMAN, eles não podem demonstrar que estão com medo, para não se colocarem em uma posição de maior vulnerabilidade frente aos presos. A necessidade de ter que esconder o medo também é um fator gerador de angústia. Para um de seus entrevistados, a única forma de lidar com o medo é bater em alguém. Deste modo se sente valorizado e mais forte, contribuindo para criar a cultura de que os guardas são melhores do que os presos ${ }^{404}$.

De acordo com uma das agentes penitenciárias entrevistadas por TAETS,

O medo (...) é algo constante: no início da carreira tal medo é bastante evidente, aos poucos, no entanto, vai-se aprendendo a lidar com ele e chega um momento em que dele se esquece. A mente esquece, se acostuma, mas o corpo continua alerta. E é então que os problemas físicos começam. ${ }^{405}$

\subsubsection{Saúde mental}

De acordo com a percepção do Poder Judiciário, o nível de estresse é muito alto na carreira de agente penitenciário e os impactos psicológicos decorrentes da profissão são intensos.

O abuso de álcool e de outras drogas como forma de lidar com o sofrimento gerado pela profissão é um dos principais elementos trazidos pela literatura ${ }^{406} 407$.

VARELLA constata, a partir dos anos de trabalho como médico no sistema prisional e de inúmeras conversas com seus amigos agentes penitenciários, que

\footnotetext{
403 Tradução livre da autora, do original: "I was scared. Every day I was scared to go to work. I really was. I was petrified”. KAUFFMAN, Kelsey. Op. cit., p. 217.

404 Idem, p. 231.

${ }^{405}$ TAETS, Adriana Rezende Faria. Op. cit., p. 64.

${ }^{406}$ KaufFman, Kelsey. Op. cit. VArella, Drauzio. Op. cit. LourenÇO, Arlindo da Silva. Op. cit.

${ }^{407}$ Uma pesquisa realizada pelo Instituto de Ciência e Tecnologia da Universidade de Manchester considerou a profissão de agente penitenciário a mais estressante dentre 104 profissões analisadas. Vide MoRAES, Pedro Rodolfo Bodê de. Op. cit., p. 226.
} 
para aliviar as tensões causadas pelo risco de perder a vida no trabalho, pela dificuldade crônica de equilibrar o orçamento doméstico e pelas reclamações da esposa carente de atenção, o agente penitenciário conta com duas válvulas de escape: a mulher e a cachaça. ${ }^{408}$

KAUFFMAN diz ser o trabalho de agente penitenciário muito exaustivo, o que faz com que muitos agentes enxerguem na bebida ou no uso de outras drogas a única saída para esquecer o mundo da prisão quando não estão em serviço.

BODÊ ${ }^{409}$ faz uma análise interessante sobre o aspecto relativo à saúde mental dos agentes penitenciários. Segundo ele, os agentes penitenciários têm dificuldade em falar e perceber as doenças que adquirem em razão do seu exercício profissional. Isso se deve ao fato de que esta forma de sofrimento está associada à fraqueza e à fragilidade, e o ASP precisa se distanciar destas imagens para conseguir manter sua autoridade e sua autoestima $^{410}$. Por esta razão, os agentes que o autor entrevistou falam sobre as doenças físicas e psíquicas que os seus colegas tiverem ou falam sobre esse tema de um modo coletivo, porém têm muita dificuldade em falar dos seus próprios desequilíbrios.

KAUFFMAN também destaca a dificuldade que os agentes penitenciários têm em manter seus relacionamentos e casamentos. Eles passaram a viver com os "nervos à flor da pele” e não conseguem mais realizar tarefas simples, como ir ao supermercado. Alguns viviam tão nervosos que davam socos nas paredes da sua casa até rompê-las e tratavam mal aqueles que mais amavam. Segundo ela, a grande maioria se vê como infeliz.

Em resumo, o trabalho na prisão afeta todas as facetas da vida dos agentes penitenciários: saúde, personalidade e família.

Para LOURENÇO,

\begin{abstract}
Atrás dos muros ou das grades de uma prisão, funcionários adoecem, ou morrem, de forma silenciosa e sem grandes alardes: transtornos de humor e transtornos neuróticos, uso abusivo de substâncias psicoativas, desordens ansiogênicas, dificuldades para dormir ou respirar, frustração profissional, alta insatisfação nas tarefas, dificuldades em manter um relacionamento conjugal
\end{abstract}

\footnotetext{
${ }^{408}$ VARELLA, Drauzio. Op. cit., p. 104.

${ }^{409}$ MORAES, Pedro Rodolfo Bodê de. Op. cit., p. 229.

${ }^{410}$ Uma discussão interessante que pode ser feita neste ponto diz respeito à associação de características identificadas como masculinas para o exercício da profissão de ASP, tais como: coragem e força. Mas, ao mesmo tempo, características identificadas como femininas, como o cuidado, também são necessárias para o bom desempenho da profissão de ASP. Isso pode gerar uma contradição interna nos agentes que querem se afirmar como "machos", mas ao mesmo tempo têm que zelar pela saúde e integridade física dos presos. É comum a reclamação por parte de ASPs de que não querem ser “babá de preso”.
} 
satisfatório e até mesmo suicídios. O espaço de vida do ASP no interior do cárcere é algo que limita as possibilidades de desenvolvimento pessoal e grupal. $^{411}$

\subsubsection{Contaminação psicológica}

De acordo com a percepção do Poder Judiciário, os agentes penitenciários ficam contaminados pelas emoções vivenciadas em seu trabalho e levam para fora do serviço as condutas e sensações pertinentes ao desenvolvimento da atividade, mas que não são adequadas nos espaços fora dos muros. Neste sentido, o Judiciário percebe que ocorre uma naturalização da violência por parte dos ASPs, em razão do que vivenciam durante os plantões.

A literatura sobre este tema é vasta e está em perfeito acordo com a percepção do Judiciário.

SABAINI percebeu, ao observar a dinâmica da cidade de Itirapina, que os familiares e demais moradores da cidade sentem-se excluídos das conversar entre os agentes penitenciários, exatamente por estes últimos utilizarem muitas gírias e dialogarem apenas sobre os acontecimentos do universo prisional. Um comerciante da cidade entrevistado pelo pesquisador disse que:

\footnotetext{
Quem não trabalha nas penitenciárias se sente excluído da conversa, como eu. Eles os \{agentes penitenciários\} só conversam entre eles, só usando gírias. $\mathrm{Na}$ minha opinião, é a cadeia que deixou eles assim, com esse comportamento. (...) Só que tem uma coisa: o salário pode ser bom, mas para mim, o emprego não é. (...) A maioria desses caras \{agentes penitenciário\} não consegue mais separar cadeia e cidade. Eles já estão inseridos num meio que não conseguem escapar. (...) Tem um amigo meu que é dono de bar, e um dia escreveu um cartaz para provocar os caras: "proibido papo de cadeia", porque ele não aguentava mais os guardas falando das penitenciárias o dia inteiro. ${ }^{412}$
}

KAUFFMAN assevera que, ao aprender a agir segundo as regras da prisão, os agentes penitenciários desaprendem a seguir as regras do mundo exterior. Eles têm a percepção de que apenas aqueles que conhecem o mundo de dentro dos muros podem compreender o

${ }^{411}$ LOURENÇO, Arlindo da Silva. Op. cit., p. 203.

412 SABAINI, Raphael. Op. cit., p. 109. 
que lá ocorre, o que faz com que os ASPs afastem-se de suas famílias e amigos próximos. Muitos sentem que perdem a capacidade de se socializar e que não têm assuntos para tratar com pessoas que não conhecem o universo de seu trabalho; utilizam apenas gírias e metáforas que se aplicam ao mundo prisional ${ }^{413}$. Isso aumenta muito o sentimento de solidão.

CASTRO E Silva segue a mesma linha de raciocínio. Ele entrevistou um psicólogo de uma unidade prisional do Rio de Janeiro e o que lhe foi dito vai ao encontro da percepção do Judiciário e dos demais autores que se debruçaram sobre este tema:

Em consequência deste ambiente de trabalho, o psicólogo dizia que muitos guardas vinham lhe procurar com pedidos de ajuda, ocasião em que se queixavam do cansaço da rotina de serviço. Nestas horas, os guardas costumavam lhe dizer que não aguentavam mais conviver na massa e que "não aguentavam mais olhar pra cara de vagabundo". Concluindo sua fala, o entrevistado ressaltou que os guardas descarregavam suas tensões em cima de terceiros como a família, os amigos ou mesmo nos colegas de trabalho. Esse comportamento, para mim, sinaliza que o exercício da função pública custodiadora poderia acabar comprometendo os relacionamentos do mundo privado. $^{414}$

A violência passa a ser naturalizada pelos agentes penitenciários, que perdem o referencial do que é agressivo e do que não é.

DrAUZIO VARELLA constata que

Praticamente todos os guardas de presídio eram pessoas com bons antecedentes, que levavam vida pacata nas ruas dos bairros em que viviam. Nem mesmo os que mais tarde adquiririam fama de "caceteiros” prestaram concurso para agente penitenciário por apresentar alguma psicopatia ou pelo prazer sádico de torturar seres humanos. A convivência diária com a brutalidade da cadeia e com a falta de respeito à vida é que os contamina e transforma. ${ }^{415}$

KAUFFMAN diz que o que era assustador no início passa a ser rotina e os agentes penitenciários começam a aceitar aquelas sensações como um elemento que compõe o seu trabalho.

Tal fenômeno da naturalização da violência e de outras formas de se comportar no ambiente prisional, como as gírias, recebe o nome de assimilação, ou prisionalização. De

\footnotetext{
${ }^{413}$ KaUfFMAn, Kelsey. Op. cit., p. 221-234.

${ }^{414}$ CAstro e Silva, Anderson Moraes de. Op. cit., p. 36.

415 VARELLA, Drauzio. Op. cit., p. 50.
} 
início, a literatura acadêmica associava este processo de aculturação como sendo típico dos presos, mas atualmente é associado também aos agentes penitenciários.

Clemmer foi o primeiro autor a trabalhar com este conceito. Segundo ele, “o termo assimilação descreve um processo lento, gradual, mais ou menos inconsciente, durante o qual a pessoa aprende o bastante sobre a cultura de uma unidade social em que foi alocada para fazer parte característica dela” ${ }^{416}$.

Para o autor, todos que entram nas prisões sofrem o processo de prisionalização por serem submetidos aos seus fatores ${ }^{417}$.

De acordo com THOMPSON, os fatores universais de prisionalização são: aceitação de um papel inferior; acumulação de fatos concernentes à organização da prisão; o desenvolvimento de novos hábitos, no comer, vestir, trabalhar, dormir; adoção do linguajar local; o reconhecimento de que nada é devido ao meio ambiente quanto à satisfação de necessidades; eventual desejo de arranjar uma "boa ocupação" ${ }^{418}$.

CHIES coordenou uma pesquisa que teve por objetivo

\begin{abstract}
identificar e analisar o processo social de inserção e assimilação dos agentes penitenciários na estrutura institucional e organizacional carcerária, mais especificamente em termos de uma hipótese especial e característica forma de socialização daqueles por parte do ambiente e sistema oficial penitenciário. ${ }^{419}$
\end{abstract}

A pesquisa permitiu concluir que os ASPs sofrem com o processo de prisionalização, em decorrência do seu ambiente de trabalho ${ }^{420}$.

De acordo com o relatório final, os processos de prisionalização são, na realidade, dessocializadores dos padrões exteriores à prisão, como KAUFFMAN também observou. Para os pesquisadores,

a prisionalização, resulta em nociva dessocialização, vez que pautado e balizado pela negação de valores sociais superiores, como a liberdade, no conflito

\footnotetext{
${ }^{416}$ Clemmer, Donald. Op. cit., p. 299.

417 Idem, p. 300.

418 THOMPSON. Augusto. Op. cit., p. 24.

${ }^{419}$ CHIES, Luiz Antônio Bogo et al. Op. cit., p. 15.

${ }^{420}$ Idem, p. 108.
} 
irresolvível dos objetivos organizacionais, e no antagonismo das dinâmicas possíveis e dos conteúdos dos papéis atribuídos aos seus participantes. ${ }^{421}$

SABAINI também identifica o processo de prisionalização de modo intenso nos agentes penitenciários de Itirapina. Ele afirma que

\begin{abstract}
o convívio intramuros faz com que o agente penitenciário adquira cada vez mais características do comportamento de um preso, tanto na maneira de falar quanto na maneira de se portar. Toda uma série de expressões corporais acabam se modificando, isto é, sofrendo a influência dos modos de comportamento dos detentos. O agente é contaminado pelo veneno presente na cadeia. $^{422}$
\end{abstract}

No que diz respeito aos três subtemas discutidos acima, tem-se que, na visão do Poder Judiciário, assim como na da literatura, o medo, o estresse e a tensão estão presentes de modo intenso na vida dos agentes penitenciários. Além disso, o Judiciário percebe a profissão de agente como de grande risco no desenvolvimento de doenças de ordem emocional. O processo de prisionalização a que estão submetidos os ASPs também compõe o universo perceptivo do Judiciário sobre esta categoria profissional.

Tais elementos perceptivos e valorativos demonstram que o Judiciário tem empatia pelos agentes e parece acreditar que estes profissionais estão esforçando-se ao máximo, comprometendo, inclusive, sua saúde física e mental para o alcance dos objetivos da execução penal, que na visão do próprio Judiciário - como visto na categoria 1 - é principalmente a busca da ressocialização do preso. Mas, paradoxalmente, os próprios ASPs estão passando por um processo de dessocialização, de acordo com a literatura estudada, o que dificulta a execução da sua missão ressocializadora.

\footnotetext{
${ }^{421}$ Idem, p. 111.

422 SABAINI, Rapahel. Op. cit., p. 94.
} 


\subsection{Categoria 10: Impacto da existência do crime organizado na atuação do}

ASP

A discussão e a interpretação deste tema, que inclui o diálogo com a literatura especializada, serão precedidas de uma breve explanação acerca das facções criminosas no Estado de São Paulo.

\subsubsection{Algumas características sobre as facções criminosas no Estado de São}

\section{Paulo}

As facções criminosas formaram-se nos presídios paulistas na década de 1990. Para compreender o contexto em que tais grupos passaram a se organizar é necessário ter em mente a política humanizadora dos presídios adotada nos anos 1980 e sua ruptura, marcada por um período em que foi adotada uma política no sistema penitenciário de cunho autoritário e violadora de direitos fundamentais ${ }^{423}$.

Existem algumas facções no Estado de São Paulo, mas a maior delas é o Primeiro Comando da Capital - PCC. As demais facções identificadas pela literatura são: Seita Satânica - SS, Comando Democrático da Liberdade - CDL, Terceiro Comando da Capital - TCC e Comando Revolucionário Brasileiro da Criminalidade - CRBC. Esta última é a segunda maior facção do Estado ${ }^{424}$.

A literatura acadêmica debruçou-se mais sobre o estudo do PCC, provavelmente por ser a facção que comanda atualmente mais de $90 \%$ das unidades prisionais do Estado $^{425}$.

\footnotetext{
${ }^{423}$ Vide SHIMIZU, Bruno. Solidariedade e gregarismo nas facções criminosas: um estudo à luz da Psicologia das massas. São Paulo: IBCCRIM, 2011. (Monografias IBCCRIM n. 60).

BIONDI, Karina. Op. cit. TeIXEIRA, Alessandra. Dispositivos de exceção... Op. cit., p. 175-208. TEIXEIRA, Alessandra. Prisões da exceção: Política penal e penitenciária no Brasil contemporâneo. 1 ed. Curitiba: Juruá Editora, 2009.

${ }^{424}$ BIONDI, Karina; MARQUes, Adalton. Memória e historicidade em dois “comandos” prisionais. Revista Lua Nova, São Paulo, p. 39-70, 2010, p. 46. SAllA, Fernando. De Montoro a Lembo. Op. cit. SALlA, Fernando. As rebeliões nas prisões: novos significados a partir da experiência brasileira. Sociologias, Porto Alegre, UFGRS, ano 8, n. 16, p. 274-307, jul./dez. 2006.

${ }^{425}$ DIAS, Camila Caldeira Nunes. Violência, PCC e prevenção do crime. Op. cit.
} 
CAMILA DiAs divide o histórico do PCC em três fases ${ }^{426}$. A primeira delas, compreendida entre $1993^{427}$ e 2001, foi marcada pela constituição e expansão da facção. Esta fase foi marcada por muita violência e rebeliões, uma vez que ocorreu em um período de “conquista de território”, em que “o sistema carcerário estava passando por um processo de reconfiguração das relações de poder" ${ }^{428}$.

A segunda fase, de 2001 a 2006, diz respeito à consolidação de uma nova configuração de poder. Com a megarrebelião de $2001^{429}$, ocorreu a publicização do PCC e a Administração Penitenciária passou a considerar a existência das facções no sistema penitenciário: o PCC transformou-se no inimigo público número 1, passando a ser o foco principal das políticas de segurança. Neste período ocorre a grande expansão desta facção.

Em 2005, após a morte violenta de sete pessoas em uma unidade prisional, decorrente da disputa por poder entre duas facções, a SAP passou a distribuir os presos pelas diferentes unidades prisionais do Estado conforme a afiliação às facções. LOURENÇO narra esse fato em sua tese de doutorado:

\begin{abstract}
Com a mega-rebelião de fevereiro de 2001, ficou claro aos dirigentes da SAP, apesar das negativas governamentais anteriores, da existência de grupos de prisioneiros organizados em facções criminosas no interior das prisões de São Paulo. Junto com o PCC (Primeiro Comando da Capital), outras organizações criminosas, principalmente o CDL (Comando Democrático da Liberdade) e o CRBC (Comando Revolucionário Brasileiro da Criminalidade) lutavam para obter o controle da instituição prisional e, quiçá, da grande massa carcerária que habitava os presídios paulistas. Depois de um evento ocorrido numa penitenciária localizada em Guarulhos, na Grande São Paulo, em 2005 quando, uma disputa pelo poder entre duas facções rivais, resultou em sete mortes violentas, uma decisão dos dirigentes da Secretaria de Estado recomendava aos órgãos subordinados a distribuição de prisioneiros segundo sua vinculação ou afiliação a uma ou outra facção criminosa, em estabelecimentos diversos. Com essa ação, estabelecimentos prisionais específicos receberam prisioneiros identificados ou associados com uma das organizações criminosas existentes. ${ }^{430}$
\end{abstract}

\footnotetext{
${ }^{426}$ No mesmo sentido, SHIMIZU, Bruno. Op. cit., p. 131-144.

${ }^{427}$ Existem diversas versões sobre o surgimento do PCC, a mais citada diz que ele se formou em 1993. Vide BIONDI, Karina. Junto e misturado. Op. cit.

${ }_{428}$ DIAS, Camila Caldeira Nunes. Da guerra à gestão. Op. cit., p. 80.

${ }^{429} 29$ unidades prisionais do Estado de São Paulo se rebelaram simultaneamente. Vide DiAs, Camila Caldeira Nunes. Violência, PCC e prevenção do crime. Op. cit. Vide BIONDI, Karina. Junto e misturado. Op. cit. EM 2001, megarrebelião comandada pelo PCC atingiu 29 penitenciárias. Folha de São Paulo online. 13 maio 2006. Disponível em: <http://www1.folha.uol.com.br/folha/cotidiano/ult95u121415.shtml>. Acesso em: 12 jan. 2013. MiLliKEN, Mary. Cadeias do país continuam fervendo um ano após megarrebelião. UOL. Disponível em: <http://noticias.uol.com.br/inter/reuters/2002/02/14/ult27u19304.jhtm>. Acesso em: 12 jan. 2013.
}

${ }^{430}$ LOURENÇO, Arlindo da Silva. Op. cit., p. 108-109. 
Os eventos de maio de 2006 demonstraram publicamente o poder do PCC. Neste período, 84 unidades prisionais - das quais dez fora do Estado de São Paulo - rebelaram-se simultaneamente e diversos ataques às forças de segurança ocorreram do lado de fora das cadeias: “229 ataques a órgãos públicos, 82 ônibus incendiados, 17 agências bancárias alvejadas a bombas, 42 policiais e agentes de segurança mortos e 38 feridos" ${ }^{431}$. A reação do aparato policial também foi extremamente violenta: registraram-se aproximadamente 500 mortes durante o curto período do dia 12 até 21 de maio, a maioria com indícios de execução. Esse período ficou conhecido como "semana sangrenta"432.

\begin{abstract}
todas estas ações foram desencadeadas por grupos criminosos de dentro do sistema penitenciário. Pela primeira vez uma crise no sistema penitenciário transbordava os muros das prisões e atingia direta e amplamente o cotidiano da população. A cidade de São Paulo paralisou suas atividades por alguns dias em maio e julho de 2006, e sua população foi tomada pelo pânico. ${ }^{433}$
\end{abstract}

A terceira fase começa em 2006 e vai até os dias atuais e corresponde ao momento em que o PCC detém a hegemonia do mundo criminal em SP. Não só dentro das unidades, mas também no controle das atividades ilícitas, estando enraizado nas periferias de São Paulo.

A literatura identifica um período de calmaria nas prisões paulistas, em razão da drástica redução de rebeliões e mortes. De acordo com SHIMIZU,

Desde o fim dos ataques, o PCC não tem, com muita frequência, sido acusado de ações que tenham causado grande repercussão midiática. Acredita-se que as lideranças da facção e as instâncias oficiais tenham chegado a um estável arranjo simbiótico de poder (...). No mesmo sentido, as relações simbióticas de poder tem-se demonstrado extramuros, nos ambientes diversos do cárcere, onde a facção já exerce sua influência de forma notória. ${ }^{434}$

\footnotetext{
431 BIONDI, Karina. Junto e misturado. Op. cit., p. 75.

432 Conectas Direitos Humanos e Laboratório de AnÁlise da ViolênCia (LAV-UERJ). Análise dos impactos dos ataques do PCC em São Paulo em maio de 2006. São Paulo. Publicado em: 2008. Disponível em: <http://www.conectas.org/documentos/Art1_relatorio_crimesdemaio2006_09.05.11.pdf>. Acesso em: 21

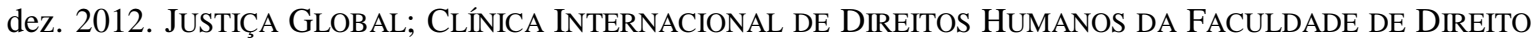
DE HAVARD. São Paulo sob achaque: corrupção, crime organizado e violência institucional em maio de 2006. São Paulo: Fundação Ford, Fundação Heinrich Boll, Open Society Institute. Publicado em: 2011. Disponível em: <http://global.org.br/wp-content/uploads/2011/05/SaoPaulosobAchaque_JusticaGlobal_2011.pdf>. Acesso em: 2 jan. 2012.

433 SALLA, Fernando. De Montoro a Lembo. Op. Cit. p. 73.

${ }^{434}$ SHIMIZU, Bruno. Op.cit., p. 143-144.
} 
Contudo, em 2012 houve um novo momento de ruptura, que provavelmente marcará o início de uma nova fase da história do PCC, mas ainda não há distanciamento seguro para ensaiar sua análise. Pode-se pressupor que houve uma ruptura nos acordos estabelecidos em 2006. No segundo semestre de 2012, diversos ataques às forças de segurança ocorreram e ao menos 100 policiais foram mortos ${ }^{435}{ }_{-}^{436}$.

O PCC reduziu de modo substancial a violência física dentro das unidades prisionais, ao mesmo tempo em que despojou os indivíduos de solucionarem seus conflitos a seu próprio modo, de maneira individual, ao criar e impor regras de convivência ${ }^{437}$. De acordo com BIONDI,

a criação do PCC é vista por muitos presos como o fim de um tempo no qual imperava uma guerra de todos contra todos, onde a ordem vigente era "cada um por si” e “o mais forte vence”. Até então, as agressões físicas [entre os presos] eram bastante comuns, "qualquer banalidade era motivo para ir para a decisão na faca”. ${ }^{438}$

Atualmente, a organização do PCC é altamente capilarizada e baseada no princípio da igualdade entre os membros da facção. Existem os “disciplinas”, que são responsáveis pela manutenção da ordem em determinado setor da unidade prisional. Há o responsável pela cobrança de dívidas - em geral de drogas. Há os “sintonias”, que são responsáveis pelo fluxo de informação e circulação de informação na cadeia. Há os responsáveis por cada raio da unidade e o "piloto geral”, posto mais alto na penitenciária. Além disso, os integrantes do PCC - chamado de "irmãos" - são distribuídos de forma a ficar pelo menos um em cada cela ${ }^{439}$.

As formas de decisão dos impasses e conflitos se dá com a formação de uma espécie de “tribunal” em que são travados debates entre todos os irmãos e só após este debate a decisão é tomada. Esta forma de resolução dos conflitos se estabelece no sentido de democratizar o PCC e fazer com que todos se sintam parte importante da facção. O peso

\footnotetext{
${ }^{435}$ Benites, Afonso. Pelo quarto mês seguido, violência aumenta em SP. Folha de São Paulo, Cotidiano, 22 dez. 2012.

${ }^{436}$ Vale ressaltar que as entrevistas desta pesquisa foram realizas ao longo do ano de 2012, porém a última entrevista foi realizada antes da deflagração deste período de violência mais intensa.

${ }^{437}$ DiAs, Camila Caldeira Nunes. Da guerra à gestão. Op. cit., p. 93.

438 BIONDI, Karina. Junto e misturado. Op. cit., p. 71.

${ }^{439}$ DIAS, Camila Caldeira Nunes. Da guerra à gestão. Op. cit., p. 85.
} 
dado aos argumentos apresentados varia em função do cargo exercido, porém todos são igualmente ouvidos. ${ }^{440}$

De acordo com DiAs,

\begin{abstract}
Nas duas últimas décadas assistimos a um agravamento das condições físicas das prisões que decorre, em grande medida, do aumento vertiginoso da população carcerária sem a correspondente melhora na infra-estrutura e na formação de funcionários, cujo número também não acompanha o ritmo frenético de crescimento de presos. Neste cenário, a corrupção e o arbítrio tornam-se a tônica dominante no relacionamento entre funcionários e presos e a violência se constitui como base deste sistema social. Na esteira deste processo de agravamento das condições materiais e morais das prisões, vimos a emergência - em São Paulo, onde estes processos ocorreram de forma mais contundente - de uma organização de presos, o Primeiro Comando da Capital (PCC) que, ao longo deste período alcançou uma capacidade de estruturação e de articulação jamais vista antes. ${ }^{441}$
\end{abstract}

Feita esta breve explanação sobre as facções criminosas, o próximo item dedicarse-á à discussão e interpretação dos dados.

\title{
5.10.2 Discussão e interpretação
}

Na percepção do Poder Judiciário, a existência de facções criminosas exerce impactos sensíveis na atuação dos agentes penitenciários. A visão apresentada pelo Poder Judiciário é de que o fortalecimento dos grupos organizados de presos produziu mudanças significativas nas formas pelas quais os ASPs exercem sua profissão. Isso deu-se tanto pela imposição de maior risco no dia a dia e aumento de ameaças, quanto pela conveniência que a presença das facções trouxe para o desempenho profissional, uma vez que as facções auxiliam na manutenção da ordem interna da unidade. Este último ponto foi destacado por apenas um dos entrevistados, mas é um dado rico que merece ser discutido em uma pesquisa qualitativa como esta.

A literatura caminha no mesmo sentido e concorda que a presença das facções nos presídios paulistas provocou mudanças significativas no exercício profissional do ASP.

\footnotetext{
${ }^{440}$ Idem, p. 88.

${ }^{441}$ Idem, p. 79.
} 
Com o fortalecimento das facções, o equilíbrio do poder dentro das unidades prisionais foi profundamente alterado.

CAMILA Dias afirma que

Hoje o PCC detém um amplo controle sobre toda a dinâmica da administração do cotidiano prisional. Em "parceria” com os funcionários públicos nos processos em que a participação destes é inevitável, como na seleção de presos para postos de trabalho, ou de forma completamente autônoma em relação à direção do estabelecimento, nos casos em que esta abre mão, deliberadamente, em exercer o seu papel de instância responsável pela administração e gestão dos presídios, o fato é que nada ocorre dentro das unidades prisionais sem o aval ou, no mínimo, o conhecimento das lideranças da facção. ${ }^{442}$

Por serem as facções instâncias negociadoras dos conflitos que ocorrem na unidade prisional e, também, possuírem suas regras de conduta próprias, o “clima” e a forma de funcionamento de cada unidade alteram-se conforme a facção que predomina em determinado momento. Há uma relação de troca entre o Estado e a facção, estabelecendose, segundo SHIMIZU, uma relação simbiótica:

Não se contesta o fato de que as facções sejam pólos de produção de regras diversos do Estado, mas a relação entre as facções e os órgãos oficiais encontra pontos de convergência e de divergência, sendo, por vezes, simbiótica. Desse modo, não se pode afirmar categoricamente que haja uma relação de paralelismo entre os dois entes, uma vez que as facções e as instâncias oficiais, ainda que, por diversas vezes, entrem em conflito, por outras vezes, apresentam uma relação pautada em um arranjo ou equilíbrio de poder. ${ }^{443}$

BIONDI apresenta a noção de que, com a existência do PCC como negociador nas unidades prisionais, não se estabeleceu mais a lógica da "troca de favores"; o que se tem são negociações que resultam em acordos, que podem ser revistos e desfeitos.

\footnotetext{
Em vez de trocas de favores, interesses de aliança ou expectativas de ajuda mútua, o que existe é uma disputa por recursos entre as duas partes da negociação, ou melhor, a tentativa constante de refreamento do poder alheio, que podem ser dissolvidos a qualquer momento. Os acordos decorrentes das negociações travadas não podem ser confundidos com troca de favores, pois estão inseridos num campo de lutas. Eles são firmados como solução de uma crise sem que envolvam obrigações futuras, podendo ser desfeitos com o surgimento de uma nova crise, o que denota seu caráter provisório e a
}

\footnotetext{
${ }^{442}$ Idem, p. 90.

443 SHIMIZU, Bruno. Op. cit., p. 88.
} 
necessidade de serem não só alimentados, mas constantemente refeitos ou remodelados. $^{444}$

Este equilíbrio - frágil - de poder entre ASPs e PCC só existe em função dos funcionários deterem o controle do fornecimento de água, comida e do acesso à assistência médica; enquanto os presos possuem o poder de romper a ordem desejada pelos funcionários, dando início a rebeliões e revoltas ${ }^{445}$. Ademais, o estresse da profissão é maior, já que a situação na unidade prisional pode ser alterada a qualquer instante. Estes frágeis acordos deixam o ASP em estado de maior alerta e insegurança sobre como será o dia a dia de seu trabalho.

Contudo, TAETS identifica que os ASPs que trabalham em unidades do PCC possuem uma percepção um pouco diversa - eles identificam uma perda de poder, “essa é a maneira que os guardas encontram para falar do PCC; para eles, a organização tirou o poder dos ASPs" ${ }^{446}$.

Outro aspecto apresentado pelos entrevistados foi a percepção de que as agressões físicas aos presos praticadas por agentes tornaram-se mais raras em razão do fortalecimento e estabelecimento das facções. A literatura concorda, conforme apresentado no tópico acima.

Os juízes destacaram o fato de cada unidade ter um “ritmo” em função da facção lá custodiada. A literatura apresenta elementos que vão ao encontro dessa percepção.

BIONDI e MARQUES relatam que o CRBC adota uma postura negociadora com a administração da unidade prisional, o que inclui os agentes penitenciários, ao passo que o PCC adota uma postura combativa ${ }^{447}$. Os agentes penitenciários que trabalhavam em uma das penitenciárias em que LOURENÇO realizou sua pesquisa - unidade “comandada” pelo CRBC - alertaram-no de que o trabalho em unidades identificadas com o PCC era "mais perigoso e insalubre" ${ }^{448}$.

BIODI acrescenta que alguns presos ensinam as regras vigentes aos funcionários novos na unidade ${ }^{449}$.

\footnotetext{
${ }^{444}$ BIONDI, Karina. Junto e Misturado. Op. cit., p. 129.

445 Ibidem.

${ }^{446}$ TAETS, Adriana. Op. cit., p. 172.

447 Biondi, Karina; MARQUES, Adalton. Op. cit.

${ }^{448}$ LOURENÇO, Arlindo. Op. cit., p. 109.

${ }^{449}$ BIONDI, Karina. Junto e Misturado. Op. cit., p. 85.
} 
O PCC promove uma inversão no jogo identitário que existia entre ASPs e presos, em que os agentes circulavam entre os dois mundos - dentro e fora das unidades. Com a presença do PCC fora das unidades, esse jogo alterou-se e isso faz com que o medo sentido pelos ASPs aumente ${ }^{450}$. Agora, os presos podem promover ações contra eles fora do presídio, e podem, inclusive, fazer algo contra as famílias dos agentes.

TAETS observa que os agentes passam a ter medo de ser atacados, de morrer e de emboscada: "No entanto, esse medo não é sentido dentro do presídio, local onde as guardas ainda se sentem donas do pedaço - espaço conhecido, delimitado. O perigo vem da rua, esse lugar confuso, indefinido, desconhecido" ${ }^{451}$.

Percebe-se que o agente passa a sentir medo na rua e a sentir-se mais seguro no presídio, “o PCC, de certa forma, prende os guardas no presídio, enquanto controla a dinâmica da cidade" ${ }^{452}$.

O PCC, ao sedimentar-se e ocupar o espaço fora dos presídios, passou a realizar ameaças constantes contra os familiares dos agentes e demonstrou possuir informações específicas sobre a rotina da família dos $\operatorname{ASPs}^{453}$. O fato de ocorrerem, ocasionalmente, execuções de agentes penitenciários fora de serviço fez com que as ameaças se tornassem realmente amedrontadoras ${ }^{454}$.

Isso eleva sobremaneira o risco da atividade profissional e o medo sentido pelos ASPs. Um juiz entrevistado destacou tal elemento, ao dizer que o impacto das facções é paradoxal: ao mesmo tempo em que facilita o trabalho dos ASPs, uma vez que os presos cumprem as regras disciplinares, também é um fator de ameaça, à medida que a facção tem capilaridade fora do presídio. Ou seja, o dia a dia é mais tranquilo, mas a atividade profissional torna-se mais perigosa.

Aqui, como elemento de discussão e interpretação dos dados, é necessário refletir um pouco mais sobre esta distribuição de poder dentro da unidade. Se as facções são tão poderosas e detêm o controle da penitenciária, por que todos os presos não fogem?

Na verdade, se por um lado a condição de carência em recursos humanos e materiais deixa os ASPs em completa situação de vulnerabilidade, fazendo com que

\footnotetext{
${ }^{450} \mathrm{O}$ medo foi discutido na categoria 9, item 5.9.1.

451 TAETS, Adriana Rezende Faria. Op. cit., p. 110.

452 Ibidem.

${ }^{453}$ Idem, p. 111.

${ }^{454}$ Idem, p. 171.
} 
dependam dos presos para a realização de tarefas básicas e indispensáveis, como distribuição das refeições, por outro lado, contam com um apoio simbólico, virtual, mas ao mesmo tempo real, de outros aparatos do Estado para a manutenção da ordem e do poder na unidade.

O fato dos funcionários que cuidam da vigilância da muralha - Agente de Escolta e Vigilância Penitenciária (AEVP) - trabalharem armados e terem autorização para atirar, para evitar fugas, é um dos elementos que auxiliam o ASP a manter-se ainda com poder para negociar com as facções. O apoio da Polícia Militar, que pode ser requisitado a qualquer momento, é outro elemento que ajuda a equilibrar essa balança de poder.

Há ainda outro elemento neste jogo que é pouco trabalhado pela literatura e não apareceu nas entrevistas, mas que é essencial para a compreensão deste complexo universo: o GIR, Grupo de Intervenção Rápida. O GIR compõe a estrutura da Secretaria de Administração Penitenciária e suas bases estão espalhadas por todo o Estado.

É a "tropa de elite” da SAP, que tem a função de realizar intervenções nas unidades prisionais. Foi criado em 2011, mas instituído oficialmente pela Portaria 69, da SAP, em 2004. Essas intervenções podem ocorrer em momentos de crise, quando os ASPs que trabalham na unidade acionam o GIR. Ou podem ser "rotineiras” para a realização de blitzes nas unidades ${ }^{455}$. De acordo com o sítio do próprio Governo do Estado,

\begin{abstract}
O GIR atua nas unidades prisionais de São Paulo, na contenção de detentos ou em apoio aos demais agentes que trabalham no interior dos presídios, durante uma operação de revista, por exemplo. O grupo utiliza armamento não letal e usa equipamentos de proteção balística, bombas de efeito moral, entre outros aparatos de contenção, que o tornam um verdadeiro pelotão de elite dentro da Secretaria. $^{456}$
\end{abstract}

O GIR é conhecido por suas intervenções extremamente violentas e agressivas. Existem muitos relatos da prática de tortura, imposição de graves humilhações e destruição dos pertences dos presos durante intervenções. Com alguma frequência, todas as unidades prisionais são submetidas a revistas realizadas pelo GIR em busca de objetos ilícitos, como

\footnotetext{
455 Venceslau, Paulo Marcelo. Grupo de Intervenção Rápida (GIR) do Sistema Penitenciário São Paulo. Praia Grande. 28 abr. 2009. Disponível em: <http://www2.forumseguranca.org.br/node/22592>. Acesso em: 28 dez. 2012.

${ }^{456}$ GOVERNO DO ESTADO DE SÃo PAUlO. SP inaugura $1^{\text {a }}$ Base Operacional do Grupo de Intervenção Rápida. 29 dez. 2010.2012 Disponível <http://www.saopaulo.sp.gov.br/spnoticias/lenoticia.php?id=213351\&c=5000>. Acesso em: 28 dez. 2012.
} 
celulares, drogas e armas brancas. Estas revistas são verdadeiras demonstrações de poder e força do Estado, por meio da SAP - e, consequentemente, do ASP.

Tais ações, como são oficialmente denominadas, são tão violentas que os membros do GIR utilizam capuz para esconder suas identidades, com medo de serem reconhecidos posteriormente por algum preso e sofrerem represálias. De acordo com SABAINI,

\begin{abstract}
É necessário frisar que o uso de capuzes pelos componentes do GIR é de fundamental importância, pois quando não estão exercendo suas atividades neste grupo, trabalham normalmente como ASPs. Esta estratégia, além de arriscada, coloca estes agentes penitenciários numa situação delicada, pois se for reconhecido por um detento, isto é entendido como sentença de morte, pois o mesmo agente que convive dentro do raio, nas gaiola ou por entre os corredores da prisão pode ser o mesmo que bate com o escudo, utiliza projéteis de borracha ou explode bombas de gás lacrimogêneo ou de efeito moral dentro de uma cela ou raio. Estas práticas podem gerar situações de revolta e vingança por parte dos prisioneiros contra estes tais agentes. ${ }^{457}$
\end{abstract}

O Estado tem o monopólio da força e realiza demonstrações rotineiras deste poder perante a população carcerária.

Os ASPs também podem indicar presos para serem colocados em celas solitárias de castigo - punição para faltas graves - ou transferência para outras unidades. Estas outras unidades podem ser distantes do local de moradia da família do preso, o que impossibilita visitas, ou podem ser unidades em que o regime de segurança é maior, chegando até ao RDD, em que o preso fica em cela solitária, em isolamento total, com apenas 2 horas de banho de sol ao dia.

Por outro lado, as facções, em especial o PCC, têm realizado demonstrações de força fora dos presídios, ao cometer homicídios de policiais, agentes penitenciários, incendiar ônibus e impor “toques de recolher” em bairros da periferia ${ }^{458}$.

Para compor este mosaico de interrelação de forças, tem-se, ainda, que os ASPs recebem ordens do diretor da unidade, inclusive com relação aos acordos firmados entre a direção e o líder da facção - ou o “piloto”. Existem também ordens que são repassadas aos

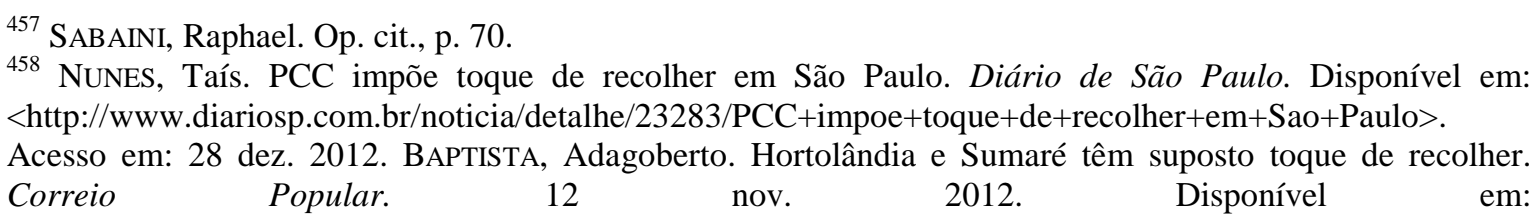
<http://correio.rac.com.br/_conteudo/2012/11/capa/campinas_e_rmc/9974-hortolandia-e-sumare-temsuposto-toque-de-recolher.html>. Acesso em: $28 \mathrm{dez} .2012$. 
ASPs pelo diretor da unidade, mas que emanaram do secretário de Administração Penitenciária ou até mesmo do governador do Estado. Os acordos e negociações com as facções ocorrem em todos os graus, no baixo escalão - diretamente com os ASPs no cotidiano prisional - até o mais alto escalão, chegando ao governador do Estado. Não se conhece publicamente o teor da negociação realizada em 2006, mas, certamente, foi uma negociação que envolveu a alta cúpula do governo e do PCC.

Por outro lado, poder-se-ia acrescentar a esta discussão o fato de que o PCC necessita do sistema penitenciário para existir e para fortalecer-se - uma vez que são as pessoas presas que passaram a integrar a facção e o acréscimo de integrantes aumenta sua força. Neste sentido, a questão que se coloca é se o PCC seria defensor de uma postura abolicionista em Direito Penal, em que não existisse mais pena de prisão? Difícil responder a essa questão, mas é mais um elemento que é colocado nesta intrincada dinâmica.

A presença das facções criminosas no sistema prisional foi bastante abordada nas entrevistas como um fator gerador de grande impacto na atuação profissional e na própria vida dos agentes penitenciários ${ }^{459}$.

A percepção, por parte do Poder Judiciário, de que a presença das facções altera o jogo de forças e as regras que regem as unidades prisionais é importante para que os magistrados possam compreender o contexto em que os conflitos estão inseridos. Deste modo, os juízes podem proferir decisões conscientes de seus impactos. Isto relaciona-se com o apresentado nas categorias 2 e 6, de que os juízes acreditam que precisam respaldar o trabalho do agente penitenciário e por isso julgam com rigor as faltas graves. Deste modo, o Judiciário está expressando sua percepção de que o ASP é o lado mais fraco no instável equilíbrio de poder e que há necessidade de apoio institucional do Poder Judiciário para auxiliá-lo a manter-se em sua posição.

Mas não apenas processos que envolvam agentes penitenciários podem ser julgados de forma mais consciente pelo Judiciário. Os impactos destas decisões podem ser melhor avaliados quando se tem uma visão de conjunto. Decisões sobre condenações de réus

\footnotetext{
${ }^{459}$ Alguns outros elementos foram abordados na discussão das categorias 5, 6 e 9, itens 5.5, 5.6 e 5.9.
} 
primários, por exemplo, podem ser repensadas, já que essas prisões provavelmente alimentariam os quadros de alguma facção criminosa.

Outros casos em sede de execução penal, que não tenham ASPs envolvidos, também podem ser melhor avaliados, uma vez que há a compreensão do impacto que a facção criminosa exerce sobre a unidade prisional e sobre o sistema penitenciário, não apenas no exercício profissional do ASP.

Nota-se que a presença das facções criminosas também produz impactos sobre o Judiciário, o que poderia ser objeto de outras pesquisas. 
Este capítulo destina-se a fazer um encerramento de todo o trabalho, ao apresentar as conclusões da pesquisa, que, mesmo estando circunscrita a margens bem delimitadas, permite inferências e reflexões baseadas nos dados colhidos, na literatura estudada e na experiência da pesquisadora ${ }^{460}$. Adicionalmente, ao final, serão lançadas sugestões para novas pesquisas. O capítulo dividir-se-á em três partes: (i) linhas perceptivas; (ii) reflexões a partir dos resultados da pesquisa; e (iii) sugestões de futuras pesquisas.

Foram realizadas oito entrevistas com juízes das Varas de Execução Criminais do Estado de São Paulo acerca da percepção do Poder Judiciário sobre os agentes penitenciários. A partir destas entrevistas foram criadas dez categorias de análise com base nas quais foram desenvolvidas análises, discussões e interpretações dos dados. Tais elementos norteiam este último capítulo.

\subsection{Linhas perceptivas}

A partir do exposto nos capítulos 4 e 5, foram extraídas cinco grandes linhas perceptivas que transpassam todas as dez categorias de análise e oferecem uma visão de conjunto dos principais achados da pesquisa. Essas cinco grandes linhas são o extrato da percepção do Poder Judiciário sobre os agentes penitenciários, captada por meio das entrevistas sobre as quais se alicerça esta dissertação.

As cinco linhas perceptivas são:

- $\quad$ Função do ASP: ressocializadora vs. disciplinar;

- $\quad$ Poder do ASP;

${ }^{460}$ Vide supra Apresentação. 
- $\quad$ Influência da facção criminosa no trabalho do ASP;

- Impactos psicossociais do trabalho do ASP; e

- $\quad$ Contexto de atuação do ASP.

A seguir, cada uma destas linhas perceptivas será objeto de breve exame.

\subsubsection{Função do ASP: ressocializadora vs. disciplinar}

O Poder Judiciário valoriza a função ressocializadora em detrimento da função disciplinar do ASP. Ao valorizar mais a função ressocializadora e colocar o ASP como peça fundamental na busca deste objetivo, o Poder Judiciário demonstra a valoração positiva que tem sobre os agentes. Neste sentido, o Judiciário considera importante a formação teórica e intelectual dos ASPs, para que possam desempenhar melhor tal importante função. O Judiciário tem a percepção de que a relação entre os presos e os ASPs é de parceria, que caminham juntos na busca da ressocialização.

O Judiciário não deixa de considerar, em seus depoimentos, a função disciplinar e a importância desta. Para os juízes, os ASPs são responsáveis por manter a disciplina na unidade e fazer com que a prisão continue a ser uma prisão.

Deste modo, o Judiciário entende que as funções, disciplinar e ressocializadora são executadas pelos ASPs, porém os mesmos deixam a desejar no que diz respeito à ressocialização, já que falta-lhes preparo para que possam atuar em prol de tal ideal a contento.

A literatura apresenta uma visão um pouco divergente da percepção dos fatos apresentada pelo Judiciário quanto à realidade, entendendo que a função disciplinar é predominante no dia a dia do ASP, ao passo que a execução, pelos agentes, da tarefa de ressocialização, é considerada utópica.

Com efeito, a manutenção da ordem interna só é possível em função dos acordos firmados entre agentes e presos, sendo estes últimos, no Estado de São Paulo, representados por facções criminosas. As condições do sistema carcerário dificultam, e muitas vezes impedem, o desenvolvimento de trabalhos que busquem a ressocialização. 


\subsubsection{Poder do ASP}

Nas entrevistas realizadas, o Judiciário focalizou aspectos distintos. Enquanto alguns juízes destacaram expressamente o grande poder exercido pelos ASPs sobre os presos, outros buscam atuar no sentido de um franco respaldo à atuação dos ASPs por meio da valorização de seus depoimentos nos processos que julgam, e há ainda os que ressaltam o papel do diretor da unidade no fortalecimento do poder dos agentes. Chegam, inclusive, a relacionar o exercício do poder a atos de improbidade.

Ficou clara, pela pesquisa, a percepção do Judiciário no sentido de que, com o fortalecimento das facções, o equilíbrio de poder dentro das unidades prisionais ficou profundamente alterado.

A literatura enfatiza os acordos informais e a constituição de um regramento que não está respaldado pela ordem jurídica. Além disso, dá destaque para a influência das facções criminosas na definição do papel no ASP. Por fim, realçam o poder que as turmas de agentes penitenciários veteranos impõem sobre os novatos por terem maior conhecimento prático do funcionamento da cadeia.

\subsubsection{Influência da facção criminosa no trabalho do ASP}

O Judiciário, de modo geral, atribui à influência das facções criminosas os atos de corrupção cometidos por ASPs; a elevação do risco desta atividade profissional - seja pela ocorrência efetiva ou latente de rebeliões, seja pelas ameaças a que submetem os ASPs -, sobretudo as decorrentes da atuação das facções fora das prisões. Além disso, identificam a influência positiva exercida pelas facções na manutenção da ordem interna da unidade, embora com um aumento do medo, tensão e estresse vivido pelos ASPs em seu cotidiano.

A literatura posiciona-se de modo concorde com essa visão do Judiciário. 


\subsubsection{Impactos psicossociais do trabalho do ASP}

O Judiciário posicionou-se de modo consistente ${ }^{461}$, e em concordância com a literatura, sobre os impactos sociais, psicológicos e emocionais que o trabalho do ASP produzem sobre os mesmos. Em primeiro lugar, citaram os fatores sociais, e sua decorrência psicológica, da identificação entre os agentes e os presos. Ademais, identificam a alteração de comportamento dos ASPs mimetizando, fora do ambiente prisional, aqueles lá adquiridos, que inclui a naturalização da violência. A literatura denomina esse processo de prisionalização.

Além disso, o adoecimento decorrente da prática profissional em ambientes insalubres e permeados por violência foi ressaltado pelos entrevistados e estudiosos do tema. A situação de constante ameaça e risco - agravada pela presença das facções debilita a saúde psíquica e consequentemente orgânica dos ASPs.

\subsubsection{Contexto de atuação do ASP}

Segundo o Judiciário, os principais fatores que configuram o cenário de trabalho dos ASPs são a precariedade das condições prediais, materiais e de recursos humanos, amplificada pela grande e crescente superlotação das unidades, com seu corolário de grave insalubridade. A questão da carreira do ASP também está presente na discussão sobre o contexto da sua atuação, notadamente em função dos salários (e da estabilidade conferida pela legislação que rege o serviço público).

Observa-se uma concordância entre as manifestações do Judiciário e da literatura no que diz respeito ao contexto de atuação dos ASPs.

\footnotetext{
${ }^{461}$ Apenas um dos entrevistados disse que o trabalho dos ASPs não é muito tenso. Vide Capítulo 4.1.3.
} 


\subsection{Reflexões a partir dos resultados da pesquisa}

As reflexões críticas que se seguem decorrem, à guisa de conclusões, dos resultados da presente pesquisa, da análise da literatura estudada e dialogam, necessariamente, com a experiência da militância profissional da pesquisadora.

\section{1}

Em primeiro lugar, cumpre destacar que as entrevistas revelaram a grande importância que o Poder Judiciário atribui ao agente penitenciário, valorizando-o por seu papel no âmbito da execução penal. Este dado contrapõe-se à percepção que os ASPs têm sobre o valor a eles atribuído pelo Judiciário, conforme estudo de CHIES, cuja pesquisa demonstrou que os ASPs não se sentem muito valorizados pelo Judiciário. É claro que ressalvas de tempo e espaço devem ser feitas, bem como de metodologia. Mas a contraposição destas percepções, a partir de estudos diferentes, permite formular a hipótese de que esta valorização expressa pelo Judiciário não chega até os ASPs, ou seja, eles não percebem essa valorização.

De acordo com a pesquisa coordenada por $\mathrm{CHIES}^{462}$, a percepção do grau de valorização que os agentes penitenciários sentem que outros grupos profissionais atribuem a eles, se reduz na medida em que o grupo está mais distante do cotidiano vivido pelos ASPs. Na visão dos agentes, os magistrados constituem um grupo de figuras distantes.

$\mathrm{Na}$ pesquisa de CHIES, cabia ao agente penitenciário dizer como ele próprio percebia o grau de valorização que os juízes lhe atribuíam. Os ASPs tinham que responder se sentiam-se valorizados pelos juízes: 10\% dos ASPs responderam que os juízes valorizam muito os agentes penitenciários; 26,67\% dos ASPs disseram que os juízes valorizam os ASPs; $50 \%$ dos agentes responderam que os juízes não valorizam, nem desvalorizam os ASPs; segundo 13,33\% dos ASPs, os juízes desvalorizam os agentes; e nenhum ASP considerou que os juízes desvalorizam muito os agentes ${ }^{463}$.

\footnotetext{
${ }^{462}$ CHIES, Luis Bogo et al. Op. cit.
}

${ }^{463}$ Idem, p. 61. 
Talvez uma das explicações para este resultado decorra do pouco contato estabelecido entre juízes e agentes. Sendo assim, essa alta valorização externada durante a presente pesquisa não pode chegar aos agentes.

Com efeito, os juízes entrevistados nesta pesquisa, em geral, revelaram terem pouco contato com os agentes penitenciários (vide categoria 2 e súmula analíticodescritiva n. $5^{464}$ ). Note-se que é dever legal do juiz de execução visitar mensalmente as unidades prisionais sob sua jurisdição. Entretanto, o que se observa é que essa obrigação vem sendo cumprida apenas em seu aspecto formal, mas não no espírito da lei, pois estas visitas - que deveriam ter um caráter de inspeção - acabam, muitas vezes, tornando-se meras visitas de cortesia aos diretores da unidade.

Cumpre destacar que, apesar dos juízes serem os corregedores das unidades prisionais, eles não se percebem como hierarquicamente superiores aos ASPs (vide categoria 2 e súmula analítico-descritiva n. $6^{465}$ ). Neste sentido, os magistrados necessitam assumir suas responsabilidades como juízes da execução e assumir as responsabilidades decorrentes deste papel. Isso não significa assumir uma posição hierarquicamente superior aos agentes penitenciários; ao contrário, os juízes poderiam aproveitar o conhecimento haurido pelos ASPs a partir da experiência cotidiana no cárcere. Assim, poderiam desempenhar de modo mais efetivo o seu papel de juízes da execução e corregedores das unidades prisionais.

O ASP é figura central para a compreensão do complexo universo carcerário em todas as suas implicações. Mas os juízes, apesar de terem afirmado valorizar muito os agentes penitenciários, não demonstraram esforço para ter contato com eles. Salvo poucas exceções, que apareceram nas entrevistas, o contato entre juiz e ASP revelou-se muito restrito. É fundamental que esta troca de informações e este fluxo de ideias entre ASPs e Judiciário existam para que o Judiciário possa realizar um trabalho com efetivo potencial para alterar a realidade.

\footnotetext{
${ }^{464}$ Vide itens 4.2.2, 5.2 e 4.3.

${ }^{465}$ Vide itens 4.2.2, 5.2 e 4.3.
} 
Pode-se concluir que o Judiciário valoriza a função ressocializadora em detrimento da função disciplinar do ASP. O Judiciário tem a percepção de que a relação entre os presos e os ASPs é de parceria, na busca da ressocialização (vide categoria 3 e súmula analítico-descritiva n. $9^{466}$ ). Os entrevistados consideram importante a função disciplinar: para eles, os ASPs são responsáveis por manter a disciplina na unidade e fazer com que a prisão continue a ser efetivamente uma prisão (vide categoria 1 e súmulas analíticodescritivas n. 2 e $3^{467}$ ).

Contudo, a literatura acadêmica ${ }^{468}$, bem como o trabalho e a militância relacionada ao tema prisional mostram uma realidade diversa. Não há espaço para qualquer função ressocializadora no cotidiano carcerário. As vagas de trabalho e educação para os presos são muito limitadas. No Estado de São Paulo, apenas 22\% dos presos estão desenvolvendo alguma atividade laborativa e 7\% estão inseridos em atividades educacionais ${ }^{469}$.

O número diminuto de agentes penitenciários frente à população prisional também não permite que um trabalho individualizado de conscientização seja desenvolvido. Assistência social $^{470}$, assistência psicológica ${ }^{471}$, assistência médica ${ }^{472}$, assistência odontológica $^{473}$ e assistência jurídica ${ }^{474}$ são tão escassas que não é possível implantar nenhuma política, apenas atender casos individuais, isolados e, em geral, emergenciais.

O Judiciário percebe uma carência de formação dos ASPs para desempenhar a importante função ressocializadora, contudo, é necessário que muito mais seja feito para que os ASPs possam atuar em prol da ressocialização (vide categoria 1 e súmula analítico-

\footnotetext{
${ }^{466}$ Vide itens 4.2.3, 5.3 e 4.3.

${ }^{467}$ Vide itens 4.2.1, 5.1 e 4.3.

${ }^{468}$ Vide supra capítulo 2.

${ }^{469}$ MinisTÉRIO DA JUSTIÇA. São Paulo-SP. Op. cit.

${ }^{470}$ São 360 assistentes sociais em todo o Estado de São Paulo. Idem.

${ }^{471}$ São 374 psicólogos em todo o Estado de São Paulo. Idem.

472 São 86 clínicos gerais, 2 ginecologistas e 51 psiquiatras em todo o Estado de São Paulo. Idem.

473 São 159 dentistas em todo o Estado. Idem.

${ }^{474}$ São 500 defensores públicos para atender toda a população vulnerável do Estado de São Paulo em todas as áreas, não apenas em execução penal e na área criminal. Em 2012, foi aprovada a criação de mais 400 cargos de Defensores Públicos. DPESP. Governador do Estado sanciona projeto de lei que cria 400 novos cargos de Defensor Público do Estado. 13 dez. 2012. Disponível em: $<$ http://www.defensoria.sp.gov.br/dpesp/Conteudos/Noticias/NoticiaConsulta.aspx?idItem=45013\&idPagina $=1>$. Acesso em: 29 dez. 2012.
} 
descritiva n. $1^{475}$ ). Não basta a realização de cursos se a estrutura é tão carente e negligenciada pelo Poder Público que impede a realização de políticas sérias.

Ademais, como percebido pelo Judiciário e apontado pela literatura ${ }^{476}$, os ASPs sofrem os efeitos da prisionalização e, de acordo com CHIES, passam por um processo de dessocialização ${ }^{477}$ (vide categorias 3, e 9 e súmula analítico-descritiva n. $10^{478}$ ). Como podem, então, ser responsáveis por implementar o ideal ressocializador? Essa exigência é cruel, pois coloca os ASPs na condição de responsáveis por realizar algo irrealizável, ou seja, estão em uma posição em que a única opção é o fracasso.

A estrutura física e básica das unidades prisionais é tão precária que chegam a ser desumanas. Tais estruturas desumanas não afetam negativamente apenas os presos. $\mathrm{O}$ impacto sobre os ASPs é gigantesco; não é sem razão que os agentes costumam dizer que cumprem pena em regime semiaberto invertido - trabalham na prisão e dormem em casa.

Os impactos psicológicos sobre os ASPs e as doenças por eles adquiridas em decorrência do exercício profissional são seríssimas e não podem ser negligenciadas. O Judiciário, de modo geral, percebe a gravidade dos impactos psicológicos que o trabalho em prisões exerce sobre os ASPs (vide categorias 6, 8 e 9 e súmula analítico-descritiva n. $\left.17^{479}\right)$.

O Judiciário tem poder de interdição de unidades prisionais. É uma das únicas atividades jurisdicionais que independem de provocação, mas é pouco utilizada pelos juízes. Se os juízes corregedores de presídio têm poder de interditar a unidade, eles também têm o poder de exigir reformas que alterem suas condições ou de promover interdições parciais. Mas tal recurso é pouco utilizado. Provavelmente, o efeito simbólico de uma única interdição já irradiaria efeitos benéficos por todo o sistema prisional, sobretudo no âmbito de sua região.

\footnotetext{
${ }^{475}$ Vide itens 4.2.1, 5.1 e 4.3.

${ }^{476}$ Vide supra capítulo 2.

${ }^{477}$ CHIES, Luiz Bogo et al. Op. cit.

${ }^{478}$ Vide itens 4.2.3, 4.2.9, 5.3, 5.9 e 4.3.

${ }^{479}$ Vide itens 4.2.6, 4.2.8, 4.2.9, 5.6, 5.8, 5.9 e 4.3.
} 
O Judiciário, nas entrevistas realizadas, mostrou conferir grande importância à função ressocializadora do ASP (vide categoria 1 e súmula analítico-descritiva n. $2^{480}$ ).

Ocorre que o presídio, como um todo, deve estar voltado para a ressocialização, já que este é o ideal presente na Lei de Execução Penal ${ }^{481}$. Em outros termos, a dinâmica da unidade prisional deve voltar-se para a individualização da pena. Neste contexto, os ASPs, a partir de seu locus privilegiado, que é o zelo pela segurança e disciplina, devem ter seu olhar voltado, também, para a individualização, mesmo sua função principal não sendo a ressocialização.

A equipe responsável, no presídio, por liderar a busca da individualização é a Comissão Técnica de Classificação (C.T.C.), que é integrada por diretores de serviço, o que inclui o diretor de segurança ${ }^{482}$. O Diretor do presídio - presidente da C.T.C. - deveria zelar para que houvesse comunicação e entrosamento constantes entre os integrantes da C.T.C. e os ASPs.

O Judiciário reconhece que é função do ASPs participar do trabalho de ressocialização, o que leva à reflexão de que o Judiciário deveria valorizar esse entrosamento entre equipe de segurança e equipe técnica. Como decorrência, o Judiciário, ao solicitar uma avaliação técnica para fins de concessão de benefícios, deveria valorizar a avaliação feita pela C.T.C., ou seja, o parecer da C.T.C. e não o exame criminológico.

Até a reforma da Lei de Execuções Penais sofrida em 2003, era exigência legal o parecer da C.T.C. para a concessão de progressão de regime e outros benefícios ${ }^{483}$. Com a

\footnotetext{
${ }^{480}$ Vide itens 4.2.1, 5.1 e 4.3.

${ }^{481}$ Lei 7.210/84 - Lei de Execução Penal - Art. 1º: A execução penal tem por objetivo efetivar as disposições de sentença ou decisão criminal e proporcionar condições para a harmônica integração social do condenado e do internado. (grifo nosso)

${ }^{482}$ Lei 7.210/84 - Lei de Execução Penal - Art. 6º: A classificação será feita por Comissão Técnica de Classificação que elaborará o programa individualizador da pena privativa de liberdade adequada ao condenado ou preso provisório.

483 Lei 7.210/84 - Lei de Execução Penal: Art. 112 - (redação vigente até 2003) A pena privativa de liberdade será executada em forma progressiva, com a transferência para regime menos rigoroso, a ser determinada pelo Juiz, quando o preso tiver cumprido ao menos 1/6 (um sexto) da pena no regime anterior e seu mérito indicar a progressão. Parágrafo único. (redação vigente até 2003): A decisão será motivada e precedida de parecer da Comissão Técnica de Classificação e do exame criminológico, quando necessário. (grifo nosso)
} 
alteração legislativa (decorrente da Lei 10.792/2003) ${ }^{484}$, o parecer da C.T.C. deixou de ser exigido e muitos magistrados passaram a requisitar a realização de exame criminológico para fundamentar e subsidiar suas decisões. Até 2003, corriqueiramente o parecer da C.T.C era realizado na forma do exame criminológico. Com a alteração legislativa, a avaliação técnica deixou de ser exigida, mas muitos magistrados continuaram a requisitar o exame criminológico.

Ocorre que as C.T.C.’s são órgãos multiprofissionais, cuja composição é estabelecida pela LEP e inclui dois chefes de serviço, um psiquiatra, um psicólogo e um

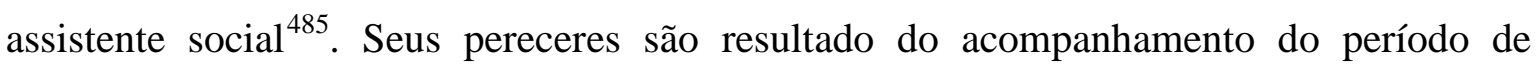
cumprimento da pena feito pela equipe técnica e servem como base para a adequação do plano individualizador traçado para cada preso.

Não são perícias e tampouco laudos conclusivos; constituem, na verdade, documentos destinados primordialmente a cada preso, entendido como ser humano total, e não apenas criminoso ou pessoa aprisionada. São realizados, primordialmente, no interesse deste próprio preso e devem subsidiar decisões judiciais em sede da execução penal.

O exame criminológico, por sua vez, é uma perícia criminológica que se debruça sobre o estudo da dinâmica do ato criminoso considerado isoladamente, relacionando-o a traços da personalidade do sujeito criminalizado. Busca oferecer um diagnóstico criminológico e um consequente prognóstico de reincidência bem como, por fim, uma indicação de conduta.

O Código Penal brasileiro prevê a obrigatoriedade de realização do exame criminológico, no início da execução da pena, para todos os condenados à pena privativa de liberdade em regime inicial fechado ${ }^{486}$. Este exame criminológico inicial de classificação não é realizado sob o pretexto de carência de recursos e profissionais, sendo quando muito - substituído por meros informes.

\footnotetext{
${ }^{484}$ Lei 7.210/84 - Lei de Execução Penal: (Redação dada pela Lei 10.792, de 2003) Art. 112: A pena privativa de liberdade será executada em forma progressiva com a transferência para regime menos rigoroso, a ser determinada pelo juiz, quando o preso tiver cumprido ao menos um sexto da pena no regime anterior e ostentar bom comportamento carcerário, comprovado pelo diretor do estabelecimento, respeitadas as normas que vedam a progressão.

${ }^{485}$ Lei 7.210/84 - Lei de Execução Penal: Art. $7^{\circ}$ : A Comissão Técnica de Classificação, existente em cada estabelecimento, será presidida pelo diretor e composta, no mínimo, por 2 (dois) chefes de serviço, 1 (um) psiquiatra, 1 (um) psicólogo e 1 (um) assistente social, quando se tratar de condenado à pena privativa de liberdade. Parágrafo único. Nos demais casos a Comissão atuará junto ao Juízo da Execução e será integrada por fiscais do serviço social.

${ }^{486}$ Decreto-lei 2.848/40 - Código Penal: Art. 34, O condenado será submetido, no início do cumprimento da pena, a exame criminológico de classificação para individualização da execução.
} 
A Lei de Execução Penal estabelece que o condenado à pena privativa de liberdade será submetido a exame criminológico com o objetivo de colher elementos necessários para a classificação dos presos, com o fito de se realizar a individualização da execução da pena $^{487}$. Também o artigo 112 da Lei de Execução Penal previa a realização do exame criminológico, quando necessário, previamente à decisão judicial sobre progressão de regime, o que foi abolido em 2003.

Isso não impediu, no entanto, que os juízes continuassem determinando sistematicamente a realização do exame criminológico a fim de decidir sobre a progressão, ou mesmo para decidir sobre outros direitos do preso no curso da execução da pena.

Portanto, ao valorizar a função ressocializadora da pena e a importância do ASP na consecução desta, o Judiciário deveria, também, assumir seu papel e responsabilidade, adotando as providências que estão ao seu alcance e previstas em Lei.

O Judiciário, ao valorizar o comprometimento do ASP com todo o trabalho de individualização da execução, deveria, por coerência, preocupar-se com toda a dinâmica prisional e com todo o histórico do preso. Isso porque o ASP, enquanto agente de segurança penitenciária, não lidera e nunca liderará trabalhos de ressocialização, contudo, sob a liderança da equipe técnica, poderia realizar seu trabalho sempre de forma a harmonizá-lo com as metas da ressocialização.

Como se espera que o juiz de execução tenha uma visão de conjunto da dinâmica prisional e valorize essa visão, então, por coerência, os magistrados também deveriam exigir um trabalho conjunto entre ASPs e integrantes da C.T.C. dentro das unidades prisionais. Consequentemente, no momento em que requisitar a realização de uma avaliação técnica, deverá solicitar uma avaliação de conjunto, e não apenas o exame criminológico $^{488}$.

\footnotetext{
487 Lei 7.210/84 - Lei de Execução Penal: Art. 8º O condenado ao cumprimento de pena privativa de liberdade, em regime fechado, será submetido a exame criminológico para a obtenção dos elementos necessários a uma adequada classificação e com vistas à individualização da execução. Parágrafo único. Ao exame de que trata este artigo poderá ser submetido o condenado ao cumprimento da pena privativa de liberdade em regime semi-aberto.

${ }^{488}$ SÁ, Alvino Augusto de. Op. cit.
} 


\section{4}

Cumpre destacar que a percepção do Judiciário captada por esta pesquisa é de que as condições das unidades prisionais são precárias e insalubres (vide categoria 8 e súmula analítico-descritiva n.16 ${ }^{489}$ ). Se o Judiciário tem essa percepção, que corresponde à realidade, por que não adotar posturas para tentar romper com tanta desumanidade, que afeta agentes penitenciários e presos?

Deve-se realçar, neste sentido, que cabe aos juízes corregedores dos presídios a tarefa de criar e manter Conselhos da Comunidade em suas Comarcas, mas não são todas as Comarcas que possuem os Conselhos instalados. A implantação e o efetivo funcionamento de Conselhos da Comunidade, abrangendo todas as atribuições previstas em lei, poderia constituir um importante instrumento a serviço da melhoria deste cenário.

O Conselho da Comunidade é formado por representantes da sociedade civil nomeados pelo próprio juiz corregedor. O Conselho tem o dever de visitar mensalmente as unidades prisionais, produzir relatórios sobre a situação encontrada e sugerir medidas em prol da solução dos problemas identificados. O relatório é encaminhado para o juiz corregedor, para que sejam tomadas as providências necessárias.

De acordo com dados do Ministério da Justiça, de 2008, a situação dos Conselhos de Comunidade no Estado de São Paulo é a seguinte:

\footnotetext{
53 comarcas possuem Conselhos de Comunidade operantes, mas que não enviam relatórios ao Juízo de Execução; 14 comarcas possuem Conselhos de Comunidade que enviaram relatórios ao Juízo de Execução no ano de 2006; 22 comarcas possuem Conselhos de Comunidade, mas que não são operantes; 58 comarcas não possuem Conselhos de Comunidade. ${ }^{490}$
}

\footnotetext{
${ }^{489}$ Vide itens 4.2.8, 5.8 e 4.3.

490 MinisTÉRIO DA JUSTIÇA. Relatório da Situação Atual do Sistema Carcerário - Conselhos de Comunidade. Maio 2008. Disponível em:

$<$ http://www.google.com.br/url?sa=t\&rct=j\&q=\&esrc=s\&source=web\&cd=1\&cad=rja\&ved=0CDAQFjAA\& url=http\%3A\%2F\%2Fportal.mj.gov.br\%2Fservices\%2FDocumentManagement\%2FFileDownload.EZTSvc.a sp\%3FDocumentID\%3D\%257BEA439690-3BB8-41E0-A6BF95D030A403EC\%257D\%26ServiceInstUID\%3D\%257B4AB01622-7C49-420B-9F7615A4137F1CCD\%257D\&ei=9FT1ULCmBoSy9gTD14GgDQ\&usg=AFQjCNFXfWPGdHhkiAKIHRziJBL G3Pfxjg\&sig2=ROC0uHvpZkC7JaRF_5b97w>. Acesso em: 23 dez. 2012. p. 23.
} 
Assim, o grande potencial que estes Conselhos têm não é aproveitado, já que, em geral, o juiz corregedor não dá encaminhamento às recomendações dos conselheiros. Essa foi elencada, pelo Ministério da Justiça, como uma das principais dificuldades enfrentas pelos Conselhos de Comunidade do Estado de São Paulo ${ }^{491}$.

\section{5}

O Judiciário expressou a percepção de que a presença das facções criminosas e o fortalecimento do PCC exercem profundos impactos sobre a profissão dos agentes (vide categorias 5, 6 e 10 e súmula analítico-descritiva n. $18^{492}$ ). E de que, em consequência, o exercício do poder pelos ASPs, inerente à função custodiadora, sofre grandes alterações e torna as relações que se desenvolvem no interior do cárcere ainda mais tensas (vide categoria 10 e súmula analítico-descritiva n. $11^{493}$ ). Porém, apesar dos juízes terem expressado tal percepção, parece que ela não se reflete em suas decisões. O brutal aumento da população carcerária ${ }^{494}$ é fruto de uma política de Estado, que inclui o Poder Judiciário como um dos principais atores.

O próprio Judiciário percebe como principais fatores de risco para o ASP a presença das facções, a superlotação das unidades, a possibilidade de contraírem doenças e de serem vítimas de violência (vide categorias 6, 8, 9 e 10 e súmulas analítico-descritivas n.14, 16 e $17^{495}$.

\footnotetext{
${ }^{491}$ Idem, p. 24.

${ }^{492}$ Vide itens 4.2.5, 4.2.6, 4.2.10, 5.5, 5.6, 5.10 e 4.3.

${ }^{493}$ Vide itens 4.2.10, 5.10 e 4.3.

${ }^{494}$ No Brasil a população carcerária em junho de 2012 era de 549.577. Em junho de 2011, era de 513.802. Ou seja, a população carcerária aumentou de 35.775 pessoas em apenas um ano, o que corresponde a um aumento de quase 3.000 pessoas a mais presas por mês no país. Em junho de 2006 o total da população carcerária era de 183.728. Vale dizer que em apenas seis anos a população carcerária brasileira amentou 365.849. No Estado de São Paulo, em junho de 2012 a população carcerária era de 190.818, ao passo que um ano antes, em junho de 2011, era de 177.767. O aumento foi de 13.051 pessoas presas, ou seja, por mês a população prisional do Estado aumentou em 1.000 pessoas. Já em junho de 2006, a população prisional paulista era de 102.831, o que significa que em seis anos o aumento foi de 87.987 pessoas a mais no sistema penitenciário. Disponível em: <http://portal.mj.gov.br/main.asp?View=\%7BD574E9CE-3C7D-437A-A5B622166AD2E896\%7D\&Team=\&params=itemID=\%7BC37B2AE9-4C68-4006-8B1624D28407509C\%7D;\&UIPartUID=\%7B2868BA3C-1C72-4347-BE11-A26F70F4CB26\%7D $\geq$. Acesso em: 11 jan. 2013.

${ }^{495}$ Vide itens 4.2.6, 4.2.8, 4.2.9, 4.2.10, 5.6, 5.8, 5.9, 5.10 e 4.3.
} 
O aumento da população carcerária sem o simultâneo aumento de funcionários e de condições materiais na prisão tornou a situação do Estado de São Paulo calamitosa. O Poder Judiciário é, em grande medida, responsável pela superlotação.

Sabe-se que a quantidade de pessoas presas ilegalmente, com penas vencidas ou com direito a algum benefício não concedido é alarmante ${ }^{496}$. Além disso, a decisão pela soltura dos presos - em razão da progressão de regime e demais benefícios - também cabe ao Judiciário. Cabe a ele, sobretudo, decidir se mais pessoas irão para a cadeia, já que é responsável por impor, ou não, a pena de prisão.

Ou seja, o Judiciário é o responsável pela porta de entrada e de saída do sistema prisional; e não tem atuado no sentido de reduzir ou extinguir a superlotação.

\section{6}

De acordo com a percepção expressada pelo Judiciário, o escasso número de agentes penitenciários por plantão também dificulta, e muito, que o Estado cumpra seu papel de efetivo responsável pelo funcionamento cotidiano dos presídios. Esse é um elemento que coloca os ASPs em uma posição vulnerável frente aos presos (vide categorias 3, 5, 6, 8 e 10 e súmulas analítico-descritivas n.10, 14 e $18^{497}$ ).

Não resta outra saída, no atual contexto de precariedade, senão contar com os presos para a realização de tarefas que caberiam ao Estado cumprir. Apenas mediante acordos firmados entre agentes - representantes do Estado - e presos, é possível que um sistema penitenciário, gigantesco como o paulista, subsista com tão poucos funcionários. Verifica-se que, deste modo, as cadeias só podem ser geridas por conta dos acordos e da divisão de tarefas entre ASPs e presos. Contudo, estes acordos são de natureza frágil e podem ser rompidos a qualquer instante, notadamente em decorrência do fato de que, no

496 Em dois anos de Mutirão Carcerário realizado pelo Conselho Nacional de Justiça, foram beneficiados 48.308 presos dentre o total de 310.079 processos analisados. Estes benefícios consistem em direito à liberdade, alvarás de soltura, progressão de regime, direito a trabalho externo, entre outros. ConSELHO NACIONAL DE JustiçA. Mutirão Carcerário: raio-x do sistema penitenciário brasileiro. 2012. Disponível em:<http://www.cnj.jus.br/images/pesquisas-judiciarias/Publicacoes/mutirao_carcerario.pdf $>$ Acesso em: 10 dez. 2012. <http://www.cnj.jus.br/index.php $\geq$. Acesso em: 10 dez. 2012.

${ }^{497}$ Vide itens 4.2.3, 4.2.5, 4.2.6, 4.2.8, 4.2.10, 5.3, 5.5, 5.6, 5.8, 5.10 e 4.3. 
Estado de São Paulo, trata-se de pacto celebrado com facções criminosas, ensejando, consequentemente, o fortalecimento delas. Esta situação gera nos ASPs tensão e estresse muito grandes em razão da instabilidade permanente em que vivem.

\section{7}

De acordo com um entrevistado e com a literatura apresentada, o fortalecimento das facções criminosas levou a uma redução da violência física cometida pelos ASPs. Ao mesmo tempo, a negociação entre agentes penitenciários e presos passou a ser o modo predominante de solução dos conflitos e do estabelecimento de regras de convivência no presídio (vide categorias 3, 5 e 10 e súmulas analítico-descritivas n. 11, 12 e $18^{498}$ ).

As negociações informais sempre estiveram presentes no dia a dia carcerário e na relação entre presos e ASPs - a literatura utilizada, neste trabalho, fez esta demonstração 499 -, porém o teor e a natureza dessas negociações foram alteradas com a organização dos presos em facções.

O Judiciário percebe que apenas uma minoria dos ASPs é corrupta e violenta e que cabe ao Diretor a fiscalização das atitudes dos ASPs. Ressalve-se, porém, que neste ponto os entrevistados divergem, pois alguns consideram que há, e outros que não há, efetivamente, esta fiscalização por parte da direção da unidade (vide categorias 4 e 5 e súmula analítico-descritiva n. $13^{500}$ ).

Ademais, foi destacada a fragilidade das poucas denúncias de irregularidades cometidas pelos ASPs que chegam ao conhecimento do Judiciário (vide categorias 2 e 5 e súmulas analítico-descritivas n. 8 e $12^{501}$ ), pois, em geral, são realizadas de forma anônima e sem indicação específica de autoria e data, o que dificulta a responsabilização dos autores das irregularidades.

O papel do diretor da unidade neste cenário também é complexo e foi objeto deste trabalho. Mas o diretor, bem como os Secretários de Administração Penitenciária e de Segurança Pública e o Governador do Estado, também fazem parte do jogo de negociação entre Poder Público - mais especificamente o sistema penitenciário - e facções. Os

\footnotetext{
${ }^{498}$ Vide itens 4.2.3, 4.2.5, 4.2.10, 5.3, 5.5 e 5.10 e 4.3.

${ }^{499}$ Vide supra capítulo 2.

${ }^{500}$ Vide itens 4.2.4, 4.2.5, 5.4, 5.5 e 4.3.

${ }^{501}$ Vide itens 4.2.2, 4.2.5, 5.2, 5.5 e 4.3.
} 
acontecimentos ocorridos em maio de 2006 e seu desfecho deixam claro que as negociações entre Estado e facções é uma realidade que vai além do agente penitenciário, envolvendo outros atores de altos escalões do Governo.

\section{8}

Os entrevistados divergiram sobre o valor que deve ser dado à palavra do agente penitenciário nos processos: se deve ser aceita de modo incondicional ou com reservas (vide categorias 2 e 7 e súmulas analítico-descritivas n. 7 e $15^{502}$ ).

A forma como o Judiciário valora a palavra do agente pode produzir efeitos substanciais na maneira de agir dos ASPs, impactando a frequência e a forma de acesso ao Judiciário por eles utilizada, pois essencialmente é deles a iniciativa de abertura de procedimento de falta grave. Como são muito frequentes os casos em que participam destes procedimentos, e sempre perante o mesmo juízo, ao ASP é dado “aprender” a maneira de decidir dos juízes, passando, assim, a pensar estrategicamente o acesso ao Judiciário para alcançar seus objetivos.

Isso é particularmente importante em se considerando que o Judiciário entende a função de testemunhar faltas graves como essencial à tarefa disciplinar (vide categorias 1 , 3 e 7 e súmulas analítico-descritivas n.4 e $7^{503}$ ).

\section{9}

É notável a falta de olhar crítico apresentada em diversas falas das entrevistas realizadas. Muitas vezes os juízes exprimiram percepções que refletem muito mais, não os fatos que observam, mas o dever ser estabelecido pela lei ${ }^{504}$.

\footnotetext{
${ }^{502}$ Vide itens 4.2.2, 4.2.7, 5.2, 5.7 e 4.3.

${ }^{503}$ Vide itens 4.2.1, 4.2.3, 4.2.7, 5.1, 5.3, 5.7 e 4.3.

${ }^{504}$ Podem ser citadas, como exemplo, as afirmações dos entrevistados que compuseram a categoria 3 Relacionamento entre os ASP e os presos (vide itens 4.2.3 e 5.3). As afirmações giram em torno de aspectos legais, em especial o fato dos ASPs serem responsáveis por testemunhar o cometimento das faltas graves. Também citam as percepções dos entrevistados que foram incluídas na categoria 1- Preparo, papel e formas de atuação do ASP (vide itens 4.2.1 e 5.3), onde foi dado grande destaque ao papel ressocializador do ASP e à relação existente entre presos e agentes.
} 
Este dado pode ser interpretado de diferentes maneiras: o Judiciário pode ter receio de expor seus posicionamentos publicamente, especialmente se levado em conta o contexto da Segurança Pública que o Estado de São Paulo viveu em 2012. Outra interpretação possível também é de que o Judiciário não assume a sua parcela de responsabilidade no cenário extremo vivido por agentes penitenciários e presos.

Pode-se, também, concluir que falta conhecimento mais específico sobre o sistema penitenciário a tais juízes, por não terem nenhuma formação sobre sistema prisional e não realizarem as visitas de inspeção mensal a contento. A Disciplina de Execução Penal, por exemplo, nas Faculdades de Direito, é negligenciada e muitas nem contam com aulas sobre o tema. Ademais, após o ingresso na carreira da magistratura, é realizada apenas uma visita - quase que como cortesia - a uma única unidade prisional.

O pouco contato entre Judiciário e ASPs (vide categoria 2 e súmula analíticodescritiva $n .5^{505}$ ) compõe a justificativa para o desconhecimento revelado pelos juízes sobre o universo que permeia a profissão do agente penitenciário.

A isso soma-se um eventual desinteresse por questões relacionadas ao cárcere.

Neste sentido, um dos juízes entrevistados relatou que a percepção que os ASPs têm do Judiciário é exatamente esta: de que o juiz não conhece o sistema prisional. Por vezes os ASPs estão corretos nesta avaliação, complementou este mesmo entrevistado (vide categoria $7^{506}$ ).

Ao mesmo tempo, diversas respostas dadas às perguntas nas entrevistas foram críticas e parecem corresponder a uma compreensão da realidade ${ }^{507}$, o que demonstra a existência de diferença de posicionamento e de postura entre os entrevistados.

\footnotetext{
${ }^{505}$ Vide itens 4.2.2, 5.2 e 4.3.

${ }^{506}$ Vide itens 4.1.8, 4.2.7 e 5.7.

${ }^{507}$ Citam-se, a título de exemplo, as percepções externadas pelo Poder Judiciário e incluídas na categoria 8 Condições de trabalho do ASP, em que os juízes destacaram a precariedade das condições de trabalho a que estão submetidos os agentes (vide itens 4.2 .8 e 5.8). Podem ser citadas, ainda, as afirmações incluídas na categoria 10 - Impacto da existência do crime organizado na atuação do ASP, quando os juízes destacaram as grandes alterações que a presença das facções criminosas tiveram sobre o trabalho dos agentes. Ademais, as percepções externadas pelo Juiz 8, alocadas na categoria 3- Relacionamento entre os ASPs e os presos e na categoria 5 -Probidade dos ASPs, no que diz respeito ao poder e à origem social de ASPs e presos, revelaram o olhar crítico deste magistrado (vide itens 4.1.8, 4.2.3, 4.2 .5 e 5.3, 5.5). Outros exemplos, que também revelam o olhar crítico lançado ao sistema penitenciário, são as percepções do Juiz 3, alocadas na categoria 4 - relacionamento entre os ASPs e a direção da unidade prisional em que trabalham; e na categoria 5 Probidade dos ASPs, sobre os abusos cometidos por agentes e o papel do diretor na apuração destes (vide itens 4.1.3, 4.2.4, 4.2.5 e 5.4, 5.5).
} 
É fundamental que o Poder Judiciário tenha uma visão crítica do complexo sistema prisional, e tome consciência da intensidade das interferências que suas ações e decisões provocam.

A situação é muito negativa no mundo prisional, para todos os atores envolvidos. A sua complexidade exige uma união de forças entre todos os Poderes, mais informações, mais transparência e maior vontade política para reverter o quadro atual. É necessário que sejam somados esforços, inclusive com o Judiciário, que tem papel fundamental neste cenário. Tal Poder não pode adotar uma postura neutra, pois a suposta neutralidade está auxiliando a reprodução - se não aumentando - das mazelas do sistema penitenciário.

\section{0}

O sistema penitenciário e o Poder Judiciário são extremamente fechados. As dificuldades encontradas para a consecução desta pesquisa são um exemplo dessa realidade $^{508}$. A necessidade de alterar o projeto de pesquisa e de ter entrevistado menos juízes do que o previsto inicialmente são elementos que apenas realçam a obscuridade e o grau de fechamento destas instituições.

Os desafios enfrentados não dizem respeito apenas a esta pesquisa, mas revelam um quadro de produção ativa da obscuridade. A dificuldade de obtenção de dados sobre o sistema penitenciário e sobre o Poder Judiciário também está inserida na lógica do fechamento. A Lei de Acesso à Informação Pública, que entrou em vigor em maio de 2012, permitiu uma possibilidade para que dados e informações venham a público. É fundamental que o sistema prisional e o Poder Judiciário abram-se para novas pesquisas e sejam regidos pelos princípios republicanos. Afinal, não é possível pensar em Políticas Públicas na ausência de dados e de informações.

Esta pesquisa, apesar de bastante restrita e limitada por sua metodologia, é uma pequena fresta que permitiu um suspiro de transparência em meio a tanta obscuridade.

${ }^{508}$ Vide supra capítulos 1 e 3. 


\subsection{Propostas para complementação e aprofundamento da pesquisa realizada}

A definição da temática desta Dissertação partiu de uma ampla pesquisa bibliográfica prévia por meio da qual não foram encontradas, entretanto, obras que tratassem diretamente da temática especificamente aqui abordada: a percepção do Judiciário acerca do ASP. A escassez de trabalhos indica, desde logo, a necessidade de novos estudos que, transcendendo os umbrais da presente dissertação, venham a aprofundar e complementar a pesquisa desenvolvida.

Ademais, os estudos que serão sugeridos abaixo teriam o condão de ampliar a compreensão sobre o universo profissional dos ASPs e, como consequência, do sistema prisional. Uma maior compreensão possibilitaria o incremento de reflexões sobre a prática carcerária, que poderiam levar a propostas concretas para aplicação prática neste universo, a depender dos resultados alcançados.

A importância de se investigar especificamente aspectos perceptivos do Poder Judiciário acerca dos ASPs reside, dentre outros, no fato do Poder Judiciário desempenhar um papel fundamental na vida prisional e, ao mesmo tempo, estar distante desta - ao decidir quem ficará preso, ao solucionar demandas e conflitos que ocorrem no interior das penitenciárias e ao julgar faltas graves. Soma-se a tais elementos o fato do Poder Judiciário ter o dever de exercer o controle externo das prisões.

Outro elemento a se destacar é que o Judiciário não está sujeito à contaminação pelo cotidiano carcerário, apesar de exercer impactos diretos sobre a dinâmica intramuros, ou seja, captar sua percepção é conhecer uma visão externa, porém próxima do cotidiano dos ASPs e que a influencia de modo substancial.

As pesquisas que serão abaixo explicitadas permitiriam aprofundar o papel desempenhado pelo agente no contexto carcerário, já que acaba por impactar diretamente o desempenho de suas funções profissionais: a percepção que o Poder Judiciário tem do ASP produz efeitos na autoimagem destes; o grau de valorização conferido aos ASPs pelo Judiciário influencia as decisões judiciais; os ASPs passam a incorporar no seu exercício profissional a valorização do Judiciário etc.

Seguem-se, pois, três sugestões para futuras pesquisas, respaldadas pelas justificativas acima, além das justificativas específicas abaixo explicitadas. 
Estas três sugestões decorreram das hipóteses formuladas a partir das cinco linhas perceptivas extraídas da percepção do Judiciário apreendida nesta pesquisa (vide item 6.1 deste capítulo):

1) Problema de pesquisa: os juízes têm uma percepção valorativa positiva acerca do ASP e de sua função?

Essa percepção valorativa positiva consubstanciar-se-ia em aspectos concretos a serem pesquisados e identificados: problematizações acerca da valorização, por parte dos juízes, da participação do ASP no amplo trabalho de ressocialização, das dimensões intelectual, cultural e técnica do trabalho do ASP, além do reconhecimento, por parte dos juízes, da importância de uma profunda formação técnico-profissional do ASP.

Somada às justificativas apresentadas acima, que se aplicam às três pesquisas sugeridas, esta teria uma relevância especial, uma vez que a percepção que o Poder Judiciário tem sobre esses aspectos relacionados ao universo dos ASPs impacta na forma de atuação dos próprios juízes. Um dos resultados da presente dissertação é o achado de que os juízes buscam atuar no sentido de um franco respaldo à atuação dos ASPs por meio da valorização de seus depoimentos nos processos que julgam. A investigação mais aprofundada deste achado também poderia estar contida na pesquisa aqui sugerida.

2) Problema de pesquisa: Na percepção do Poder Judiciário, qual a influência das facções criminosas sobre a função do ASP?

Uma investigação sobre a percepção do Judiciário acerca da interação entre as facções criminosas e os ASPs se sustentaria, não apenas nas justificativas apresentadas acima, mas também no fato das facções criminosas, no Estado de São Paulo, apresentarem uma configuração peculiar se comparada às organizações de presos em outros Estados.

O impacto que as facções, em especial o PCC, exercem no sistema prisional (e no sistema de Segurança Pública) é muito grande e necessita ser objeto de mais investigações acadêmicas. A compreensão da percepção dos juízes sobre a relação que é estabelecida entre a facção e os ASPs é um ângulo que poderia ser explorado. 
Alguns achados desta dissertação poderiam ser incluídos na problematização, tais como: a alteração profunda no equilíbrio de poder dentro das unidades prisionais em decorrência do fortalecimento das facções criminosas, percebida pelos juízes; a percepção dos juízes de que as facções criminosas exercem influência nos atos de corrupção cometidos por ASPs; a identificação, por parte dos juízes, de influência positiva exercida pelas facções na manutenção da ordem interna da unidade; e, ainda, a identificação, por parte dos magistrados, da elevação do medo, da tensão e do estresse vivido pelos ASPs em seu cotidiano em razão da presença das facções criminosas também fora das unidades prisionais.

\section{3) Problema de pesquisa: qual a percepção do Judiciário acerca das condições} de trabalho do ASP?

A realização de uma pesquisa que se aprofundasse na temática relativa à percepção dos magistrados sobre as condições que envolvem o trabalho de agente penitenciário é justificada - além das justificativas já apresentadas acima - pelo fato de ser o juiz de execução um dos atores responsáveis por influir concretamente na realidade, como um indutor de mudanças positivas, da manutenção do status quo ou, até mesmo, de agravamento do quadro precário que contextualiza a atividade profissional dos ASPs.

Conhecer mais profundamente a forma como os juízes percebem os impactos sociais, psicológicos e emocionais decorrentes do trabalho dos ASPs, em razão das condições das unidades prisionais, faz-se essencial. Isto porque os juízes são órgãos da execução penal e são responsáveis pela realização do controle externo do sistema prisional, tendo, além disso, poder de determinar a interdição de unidades, recomendar e exigir providências em prol da melhoria das condições carcerárias.

Outros achados desta dissertação que poderiam ser objeto da pesquisa ora proposta são a identificação, por parte dos juízes, do processo de prisionalização experimentado pelos ASPs e, também, a percepção dos juízes de que são baixos os salários dos ASPs.

Devem ser feitas, ainda, duas sugestões metodológicas, que podem ser aplicadas nas pesquisas propostas acima: 


\section{- Ampliação da amostra}

A ampliação do tamanho da amostra - aumento do número de entrevistados - traria maior confiabilidade e segurança aos resultados.

\section{- Aumento da abrangência territorial}

As pesquisas propostas acima poderiam ser expandidas para outros Estados, propiciando, assim, um estudo comparado entre as diferentes realidades vivenciadas pelos juízes da execução e por agentes penitenciários, ou seja, abarcaria diferentes realidades penitenciárias nacionais.

\subsection{Propostas de interação}

Deve se, desde logo, ressalvar que quaisquer caminhos agora propostos revestem-se de um caráter preliminar. Isso porque a presente pesquisa aponta para algumas direções que precisam ser ainda confirmadas por estudos como os acima sugeridos.

Seguem-se agora propostas de interação que possibilitem maior intercâmbio de experiências entre o Poder Judiciário e os agentes penitenciários.

\section{1) Seminário}

Uma das formas de interação poderia se dar em seminários, congressos, colóquios e conclaves do gênero que promovessem amplas discussões, troca de ideias, apresentação de propostas e de aperfeiçoamentos, pontos de vista sobre temáticas de interesse comum entre o Judiciário - representado por juízes da execução - e o sistema prisional - representado pelos ASPs. Deve-se destacar que a presença dos técnicos seria de grande valia para o enriquecimento das discussões, uma vez que exercem papel de grande importância dentro da dinâmica prisional. 


\section{2) Audiência pública}

O Conselho Nacional de Justiça - CNJ - poderia promover uma audiência pública voltada à escuta das demandas dos agentes penitenciários com relação ao Poder Judiciário e ao sistema prisional de modo geral.

\section{3) Encontro de especialistas}

A realização de um encontro entre especialistas, envolvendo acadêmicos e outros profissionais que atuam com as temáticas relativas aos assuntos do sistema prisional; tendo, de um lado, o Poder Judiciário e os juízes, com diferentes perspectivas e, de outro, os agentes penitenciários, em diversos aspectos. A presença de técnicos do sistema prisional ou de especialistas que atuam com temáticas relativas ao papel do corpo técnico na dinâmica prisional engrandeceria o encontro. Um debate entre tais especialistas poderia ser muito enriquecedor para a temática da pesquisa ora apresentada.

\section{4) Grupo de diálogo}

Poderia ser constituído um grupo de diálogo em que fosse criado um ambiente confortável e seguro para que os juízes da execução, os agentes penitenciários, os presos e os técnicos pudessem formar um círculo de troca de experiências relacionadas ao cárcere. Nestes encontros, cada um dos participantes poderia expor livremente as questões com que se defrontam em seu cotidiano, a fim de que os demais pudessem melhor compreender determinados pontos de vista, cada um se colocando no lugar do outro e dialogando sobre as questões suscitadas. Para o bom êxito desta iniciativa, seria desejável a participação de especialistas em mediação nos encontros sugeridos, de modo a obter uma mais proveitosa condução da dinâmica de grupo estabelecida. Esta proposta, se bem realizada, poderia ter efeitos realmente transformadores em todo o sistema.

Esta pesquisa que agora se encerra buscou cumprir o relevante papel de produzir hipóteses e traçar relações que possam subsidiar novos estudos. Pretendeu-se, desta forma, 
penetrar na névoa dos territórios pouco conhecidos, abrindo frestas e clareiras. Buscou-se, assim, puxar fios que desatem importantes nós que carregam consigo densas lágrimas de sofrimento humano.

Está lançada uma semente... 
AGÊNCIA USP. Estudo aponta que expectativa de vida de agente penitenciário é de 45 anos em SP. Folha de São Paulo, Cotidiano, São Paulo, 22 nov. 2010. Disponível em: $<$ http://www1.folha.uol.com.br/cotidiano/834606-estudo-aponta-que-expectativa-de-vidade-agente-penitenciario-e-de-45-anos-em-sp.shtml>. Acesso em: 25 dez. 2012.

Alvarez, Marcos César; Salla, Fernando; Gauto, Maitê. A contribuição de David Garland: a sociologia da punição. Tempo Social, São Paulo, FFLCH/USP, v. 18, n. 1, p. 329-350, jun. 2006. Disponível em: <http://www.fflch.usp.br/sociologia/temposocial/edicoes.php>. Acesso em: 22 set. 2010.

AngotTI, Bruna. Entre as leis da ciência, do Estado e de Deus: o surgimento dos presídios femininos no Brasil.,São Paulo: IBCCrim, 2012. (Monografias IBCCRIM n. 62).

AnituA, Gabriel Ignacio. Histórias dos pensamentos criminológicos. Rio de Janeiro: Revan, 2008. (Coleção Pensamento Criminológico v. 15).

BAptista, Adagoberto. Hortolândia e Sumaré têm suposto toque de recolher. Correio Popular. 12 nov. 2012. Disponível em: <http://correio.rac.com.br/_conteudo/2012/11/capa/campinas_e_rmc/9974-hortolandia-esumare-tem-suposto-toque-de-recolher.html>. Acesso em: $28 \mathrm{dez} .2012$.

BARAtTA, Alessandro. Criminologia crítica e crítica do direito penal: introdução à sociologia do direito penal. 3 ed. Rio de Janeiro: Revan, 2002. (Coleção Pensamento Criminológico v. 1).

. Por un Concepto Crítico de Reintegración Social del Condenado. In: Oliveira, E. (Coord.) Criminologia Crítica (Forum Internacional de Criminologia Crítica). Belém: CEJUP, 1990.

$\begin{array}{ccc}\text { social” } & \text { Ressocialização ou controle social: Uma abordagem crítica da "reintegração } \\ \text { do } & \text { sentenciado. } & \text { Disponível }\end{array}$ em: <http://www.juareztavares.com/textos/baratta_ressocializacao.pdf $>$. Acesso em: 15 jan. 2012.

Bauer, Martin W; Gaskell, George. Pesquisa qualitativa com texto, imagem e som. Petrópolis: Vozes, 2002.

BECKER, Howard S. Outsiders: studies in the sociology of deviance. New York: The Free Press, 1991.

Benites, Afonso. Pelo quarto mês seguido, violência aumenta em SP. Folha de São Paulo, Cotidiano, 22 dez. 2012.

BIONDI, Karina. Junto e misturado: uma etnografia do PCC. São Paulo: Terceiro Nome, 2010. (Coleção Antropologia Hoje).

; Marques, Adalton. Memória e historicidade em dois “comandos” prisionais.

Revista Lua Nova, p. 39-70, São Paulo, 2010. 
BragA, Ana Gabriela Mendes; Bretan, Maria Emília. Teoria e prática da reintegração social: o relato de um trabalho crítico no âmbito da execução penal. In: SÁ, Alvino Augusto de; SHECAIRA, Sérgio Salomão. (Org.). Criminologia Aplicada aos Problemas da Atualidade. São Paulo: Atlas, 2008. p. 255-275.

BRASIL. Decreto-lei 2.848, de 07 de setembro de 1940. Institui o Código Penal. Disponível em: <http://www.planalto.gov.br/ccivil_03/decreto-lei/del2848.htm>. Acesso em: $21 \mathrm{dez}$. 2012.

BRASIL. Lei 7.210, de 11 de julho de 1984. Institui a Lei de Execução Penal. Disponível em: <http://www.planalto.gov.br/ccivil_03/leis/L7210.htm>. Acesso em: 21 dez. 2012.

BrASIL. Constituição da República Federativa do Brasil, de 05 de outubro de 1988. Disponível em: <http://www.planalto.gov.br/ccivil_03/constituicao/constituicao.htm>. Acesso em: 21 dez. 2012.

CARvalho, Salo. Como (não) se faz um trabalho de conclusão: provocações úteis para orientadores e estudantes de direito (Especialmente das ciências criminais). Rio de Janeiro: Lumen Juris, 2011.

Castro e Silva, Anderson Moraes de. Nos braços da lei: o uso da violência negociada no interior das prisões. Rio de Janeiro: e+a, 2008.

Centro de Apoio aos Direitos Humanos "Valdício Barbosa dos Santos"; Centro DE Defesa dos Direitos Humanos da SerRa; Conectas Direitos Humanos; JustiçA GlobAl. Violações de Direitos Humanos no Sistema Prisional do Espírito Santo: atuação da sociedade civil. Publicação em: maio 2011. Disponível em: $<$ http://www.conectas.org/documentos/SistemaPrisional_ES_final.pdf $>$. Acesso em: 25 dez. 2012.

Chauvenet, Antoinette; Benguigui, Georges; Orlic, Françoises. Le monde des surveillantes de prison. Paris: Presses Universitaires de France, 1994.

CHIEs, Luiz Antônio Bogo et al. A prisionalização do agente penitenciário: um estudo sobre encarcerados sem pena. Pelotas: Educat, 2001.

Clemmer, Donald. The prison community. 2 ed. New York: Holt, Rinehart \& Winston, 1958.

Coelho, Edmundo Campos. A oficina do diabo e outros estudos sobre criminalidade. Rio de Janeiro/São Paulo: Record, 2005.

COM 4 HOMICÍDIOS por dia, SP sofre com banalização da 'cultura do confronto'. Conectas Direitos Humanos, 26 out. 2012. Disponível em: <http://www.conectas.org/artigo-1/com4-homicidios-por-dia-sp-sofre-com-banalizacao-da-cultura-do-confronto?pg=4 $\geq$. Acesso em: 15 dez. 2012.

CONSTRUTORA vai empregar detentos em obras do estádio do Corinthians. Globo Esporte, São Paulo, 30 jan. 2012. Disponível em: <http://globoesporte.globo.com/futebol/copa-domundo/noticia/2012/01/construtora-vai-empregar-detentos-em-obras-do-estadio-docorinthians.html>. Acesso em: 9 dez. 2012.

Conectas Direitos Humanos. Disponível em: <www.conectas.org>. Acesso em: 21 dez. 2011.

CONECTAS DIREITOS HUMANOS. ONU visita Brasil para avaliar situação de tortura e maustratos no país. 21 set. 2011. Disponível em: <http://www.conectas.org/artigo-1/onu-visita-

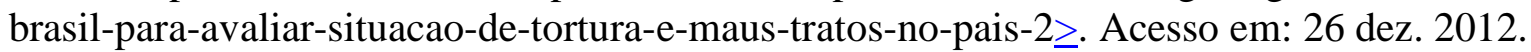


Conectas Direitos Humanos e LaboratóRio de ANÁlise da ViolÊnCia (LAV-UERJ). Análise dos impactos dos ataques do PCC em São Paulo em maio de 2006. São Paulo. Publicado em: 2008. Disponível em: <http://www.conectas.org/documentos/Art1_relatorio_crimesdemaio2006_09.05.11.pdf>. Acesso em: 21 dez. 2012.

Conselho Nacional de Justiça. Disponível em: <www.cnj.jus.br>. Acesso em: 21 dez. 2011.

. Mutirão Carcerário: raio-x do sistema penitenciário brasileiro. 2012. Disponível
emttp://www.cnj.jus.br/images/pesquisas-
judiciarias/Publicacoes/mutirao_carcerario.pdf>. Acesso em: 10 dez. 2012.

Conselho Nacional de Política Criminal Penitenciária. Relatório sobre inspeção nos estabelecimentos penais do Estado de São Paulo. 2011. Disponível em: <http://portal.mj.gov.br> Acesso em: 21 nov. 2012.

CorrêA Junior, Alceu; SHecAIRA, Sérgio Salomão. Teoria da pena: finalidades, direito positivo, jurisprudência e outros estudos de ciência criminal. São Paulo: RT, 2002.

CRAWLEY, Elaine. Doing prison work: the public and private lives of prison officers. Portland: Willan Publishing, 2006.

DE Giongi, Alessandro. A miséria governada através do sistema penal. Rio de Janeiro: Revan, 2008. (Coleção Pensamento Criminológico v. 12).

DiAs, Camila Caldeira Nunes. Efeitos simbólicos e práticos do regime disciplinar diferenciado (RDD) na dinâmica prisional. Revista Brasileira de Segurança Pública, São Paulo, n. 5, ano 3, ago./set. 2009. Disponível em: <http://revista.forumseguranca.org.br/index.php/rbsp/index>. Acesso em: 31 jan. 2012.

. Violência, PCC e prevenção do crime. In: Tertúlias Criminológicas, sobre crime, prevenção e violência. Encontro Semanal de 21 ago. 2012. Disponível em: <http://atualidadesdodireito.com.br/tertulias/exposicoes/>. Acesso em: 25 dez. 2012.

. Da guerra à gestão: a trajetória do Primeiro Comando da Capital (PCC) nas prisões de São Paulo. Revista Percurso. Sociedade, Natureza e Cultura. Curitiba, UniCuritiba, ano VIII, n. 10, v. 02, p. 79-96, 2009.

DonATo, Veruska. Onda de violência interrompe longo período de queda nos índices de SP. Jornal Hoje. Edição de: 27 nov. 2012. Disponível em: <http://g1.globo.com/jornalhoje/noticia/2012/11/onda-de-violencia-interrompe-longo-periodo-de-queda-nos-indicesde-sp.html $\geq$. Acesso em: 15 dez. 2012.

DPESP. Governador do Estado sanciona projeto de lei que cria 400 novos cargos de Defensor Público do Estado. 13 dez. 2012. Disponível em: $<$ http://www.defensoria.sp.gov.br/dpesp/Conteudos/Noticias/NoticiaConsulta.aspx?idItem $=45013 \&$ idPagina=1>. Acesso em: $29 \mathrm{dez} .2012$.

EM 2001, megarrebelião comandada pelo PCC atingiu 29 penitenciárias. Folha de São Paulo online. 132006.2 maio 2 em: <http://www1.folha.uol.com.br/folha/cotidiano/ult95u121415.shtml>. Acesso em: 12 jan. 2013.

EX-Detentos erguerão o estádio do Itaquerão. Folha de São Paulo, São Paulo, 5 ago. 2011. Disponível em: <http://www1.folha.uol.com.br/esporte/954932-ex-detentoserguerao-o-estadio-do-itaquerao.shtml>. Acesso em: 9 dez. 2012. 
EXPECTATIVA de vida aumenta 25 anos em cinco décadas, diz IBGE. Folha de São Paulo, São Paulo, 292 jun. 2012. Disponível em: $<$ http://www1.folha.uol.com.br/cotidiano/1112518-expectativa-de-vida-aumenta-25-anosem-cinco-decadas-diz-ibge.shtml>. Acesso em: 25 dez. 2012.

Figueiredo, Antônio Macena de; SouzA, Soraia Riva Goudinho. Projetos, monografias, dissertações e teses: da redação científica à apresentação do texto final. Rio de Janeiro: Lumen Juris, 2008.

FigueIRedo, Nébia Maria Almeida de. Método e metodologia na pesquisa científica. 3 ed. São Caetano do Sul: Yendis Editora, 2008.

FouCAUlt, Michel. A verdade e as formas jurídicas. Rio de Janeiro: NAU, 2009.

. Vigiar e punir: nascimento da prisão. Petrópolis: Vozes, 2007.

. Il faut tout repenser, la lois et la prison: Contre les peines de substitution: Punir est la chose la plus difficile qui soit. In: DEFERT, Daniel; EWALD, François (coords.). Dits et écrits II. 1976-1988. Paris: Gallimard, 2001.

O sujeito e o poder. In: DREYfus, Hubert; RABINOw, Paul (coords.). Michel Foucault: uma trajetória filosófica: para além do estruturalismo e da hermenêutica. Trad. Vera Porto Carrero. Rio de Janeiro: Forense Universitária, 1995.

Graal,1998.

Microfísica do poder. Trad. e org. Roberto Machado. 13 ed. Rio de Janeiro:

. Sobre a prisão. In: . Microfísica do Poder. 13 ed. Rio de Janeiro: Graal, 1998. p. 129-143.

. Table ronde du 20 mai 1978. In: Perrot, Michelle (coord.). L’impossible prison. Paris: Éditions du seuil, 1980.

Fundação Prof. Dr. Manoel Pedro Pimentel. Disponível em: $<$ http://www.funap.sp.gov.br/sobre.html>. Acesso em: 21 dez. 2011.

Garland, David. Punishment in modern society: a study in social theory. Oxford: The University of Chicago Press, 1993.

. The culture of control: rime and social order in contemporary society. Chicago: The University of Chicago Press, 2001.

GoffMAn, Erving. Manicômios, prisões e conventos. 7 ed. São Paulo: Perspectiva, 2005.

Governo do Estado DE SÃo PAulo. SP inaugura $1^{\text {a }}$ Base Operacional do Grupo de Intervenção Rápida. 29 dez. 2010. Disponível em: $<$ http://www.saopaulo.sp.gov.br/spnoticias/lenoticia.php?id=213351\&c=5000>. Acesso em: 28 dez. 2012.

Hirschbiegel, Oliver. A Experiência. Direção de Oliver Hirschbiegel. Europa filmes. Alemanha, 2001. 119 min.

Instituto Terra, Trabalho e Cidadania e Pastoral Carcerária. Tecer Justiça. Presas e presos provisórios da cidade de São Paulo. Pesquisa publicada em: 2012. Disponível em: <http://www.ittc.org.br/web/rel_tecer_justica_net.pdf>. Acesso em: 17 jul. 2012. 
Jesus, Maria Gorete Marques de. O crime de tortura e a justiça criminal: um estudo dos processos de tortura na cidade de São Paulo. São Paulo: IBCCRIM, 2010. (Monografias IBCCRIM n. 55).

; OI, Amanda Hildebrand; Rocha, Thiago Thadeu da; LAGATTA, Pedro. Núcleo de Estudos da Violência - NEV/USP. Prisão Provisória e Lei de Drogas: um estudo sobre os flagrantes de drogas na cidade de São Paulo. Sumário Executivo. São Paulo: Open Society Institute. Publicado em: 2011. Disponível em: <http://www.nevusp.org/downloads/down254b.pdf>. Acesso em: 5 jan. 2013.

Justiça Global; Clínica Internacional de Direitos Humanos da Faculdade de DiREITO DE HAVARD. São Paulo sob achaque: corrupção, crime organizado e violência institucional em maio de 2006. São Paulo: Fundação Ford, Fundação Heinrich Boll, Open Society Institute. Publicado em: 2011. Disponível em: <http://global.org.br/wpcontent/uploads/2011/05/SaoPaulosobAchaque_JusticaGlobal_2011.pdf >. Acesso em: 2 jan. 2012.

Kauffman, Kelsey. Prison officers and their world. Massachusetts: Harvard University Press, 1988.

KirchHeimer, Otto; Rusche, Georg. Punição e estrutura social. 2. ed. Rio de Janeiro: Revan, 2004. (Coleção Pensamento Criminológico v. 3).

LAKATOs, Eva Maria; MARCONI, Marina de Andrade. Metodologia do trabalho científico: procedimento básicos, pesquisa bibliográfica projetos e relatório, publicações e trabalhos científicos. 7 ed. São Paulo: Atlas, 2008.

Lemgruber, Julita; Paiva, Anabela. A dona das chaves: uma mulher no comando das prisões do Rio de Janeiro. Rio de Janeiro/São Paulo: Record, 2010.

LOURENÇO, Arlindo da Silva. O espaço de vida do agente de segurança penitenciária no cárcere: entre gaiolas, ratoeiras e aquários. 2010. Tese (Doutorado em Psicologia) Instituto de Psicologia, Universidade de São Paulo, São Paulo. 2010.

MarConi, Marina de Andrade; LAKATOS, Eva Maria. Metodologia do trabalho científico: procedimentos básicos, pesquisa bibliográfica projetos e relatório, publicações e trabalhos científicos. 7 ed. São Paulo: Atlas, 2008.

Mattos, Virgilio de. De uniforme diferente: o livro das agentes. Belo Horizonte: Fundação MDC, 2010.

MiLliken, Mary. Cadeias do país continuam fervendo um ano após megarrebelião. UOL. Disponível em: <http://noticias.uol.com.br/inter/reuters/2002/02/14/ult27u19304.jhtm>. Acesso em: 12 jan. 2013.

MinistéRIO DA JusTiÇA. Relatório da Situação Atual do Sistema Carcerário - Conselhos de Comunidade. Maio 2008.2 Disponível em: $<$ http://www.google.com.br/url?sa=t\&rct=j\&q=\&esrc=s\&source=web\&cd=1\&cad=rja\&ve d=0CDAQFjAA\&url=http\%3A\%2F\%2Fportal.mj.gov.br\%2Fservices\%2FDocumentMana gement\%2FFileDownload.EZTSvc.asp\%3FDocumentID\%3D\%257BEA439690-3BB841E0-A6BF-95D030A403EC\%257D\%26ServiceInstUID\%3D\%257B4AB01622-7C49420B-9F76-

15A4137F1CCD\%257D\&ei=9FT1ULCmBoSy9gTD14GgDQ\&usg=AFQjCNFXfWPGdH hkiAKIHRziJBLG3Pfxjg\&sig2=ROC0uHvpZkC7JaRF_5b97w>. Acesso em: 23 dez. 2012. 
Departamento Penitenciário Nacional. Sistema integrado de informações penitenciárias - InfoPen. Todas UF’s. Referência 06/2012. Disponível em: $<$ http://portal.mj.gov.br/main.asp?View=\%7BD574E9CE-3C7D-437A-A5B622166AD2E896\%7D\&Team=\&params=itemID=\%7BC37B2AE9-4C68-4006-8B1624D28407509C\%7D;\&UIPartUID=\%7B2868BA3C-1C72-4347-BE11A26F70F4CB26\%7D>. Acesso em: 23 dez. 2012.

Departamento Penitenciário Nacional. Sistema integrado de informações penitenciárias - InfoPen. São Paulo/SP. Referência 06/2012. Disponível em: <http://portal.mj.gov.br/main.asp?View=\%7BD574E9CE-3C7D-437A-A5B622166AD2E896\%7D\&Team=\&params=itemID=\%7BC37B2AE9-4C68-4006-8B1624D28407509C\%7D;\&UIPartUID=\%7B2868BA3C-1C72-4347-BE11A26F70F4CB26\%7D>. Acesso em: 23 dez. 2012.

Moraes, Pedro Rodolfo Bodê de. Punição, encarceramento e construção de identidade profissional entre agentes penitenciários. São Paulo: IBCCRIM, 2005. (Monografias IBCCRIM n. 33).

NunEs, Taís. PCC impõe toque de recolher em São Paulo. Diário de São Paulo. Disponível em: $<$ http://www.diariosp.com.br/noticia/detalhe/23283/PCC+impoe+toque+de+recolher+em+ Sao+Paulo>. Acesso em: $28 \mathrm{dez} .2012$

PAstoral CARCERÁRIA DE SÃo PAulo. Relatório sobre Tortura: uma experiência de monitoramento dos locais de detenção para prevenção da tortura. Publicado em: 2010. Disponível em: <http://carceraria.org.br/wpcontent/uploads/2012/10/Relatorio_tortura_revisado1.pdf>. Acesso em: 4 jan. 2012.

PORTAL DA TRANSPARÊNCIA EstAdUAL. Disponível em: <http://www.transparencia.sp.gov.br/>. Acesso em: 21 dez. 2011.

PRESOS vão ser contratados para trabalhar no Corinthians. G1. 2 abr. 2012. Disponível em: $<$ http://g1.globo.com/sao-paulo/noticia/2012/04/presos-vao-ser-contratados-para-trabalharno-corinthians.html>. Acesso em: 09 dez. 2012.

REDE DE PEsquisa EMPÍRICA EM DiReito. Disponível em: <http://reedpesquisa.org/>. Acesso em: 21 dez. 2011.

Rodrigues, Artur, et al. Violência em SP. Notícias, fotos e vídeos sobre "violência em SP”. Estado de S. Paulo, 3 dez. 2012, 4 dez. 2012, 9 dez. 2012, 12 dez. 2012, 17 dez. 2012, 22 dez. 2012. Disponível em: <http://topicos.estadao.com.br/violencia-em-sp>. Acesso em: 15 dez. 2012.

SÁ, Alvino Augusto de. Criminologia clínica e execução penal: proposta de um modelo de terceira geração. São Paulo: RT, 2011.

. Direitos humanos e execução penal. In: BiTTAR, Eduardo C. B. (org.). Educação e metodologia para os direitos humanos. São Paulo: Quartier Latin, 2008.

. Criminologia clínica e psicologia criminal. São Paulo: RT, 2007.

. GDUCC Grupo de Diálogo Universidade, Cárcere, Comunidade - experiência que está dando certo. Boletim IBCCRIM, v. 198, p. 11-12, 2009.

SABAINI, Raphael. Uma cidade entre presídios: ser agente penitenciário em Itirapina - SP. 2012. Dissertação (Mestrado em Antropologia Social) - Faculdade de Filosofia, Letras e Ciências Humanas, Universidade de São Paulo, São Paulo. 2012. 
SALLA, Fernando. De Montoro a Lembo: as políticas penitenciárias de São Paulo. Revista Brasileira de Segurança Pública, São Paulo, n. 1, v. 1, p. 72-90, 2007. Disponível em: $<$ http://revista.forumseguranca.org.br/index.php/rbsp/article/view/8/5>. Acesso em: 25 dez. 2012.

. As rebeliões nas prisões: novos significados a partir da experiência brasileira. Sociologias, Porto Alegre, UFGRS, ano 8, n. 16, p. 274-307, jul./dez. 2006.

SANTOS, Juarez Cirino dos. A criminologia radical. 3 ed. Curitiba: ICPC/Lumen Juris, 2008.

SchritzMeyer, Ana Lúcia Pastore. Sortilégios de saberes: curandeiros e juízes nos tribunais brasileiros (1900-1990). São Paulo: IBCCrim, 2004. (Monografias IBCCRIM n. 29).

Secretaria de Administração Penitenciária do Estado de SÃo Paulo. Disponível em: <http://www.sap.sp.gov.br>. Acesso em: 21 dez. 2011.

SeCretário de Segurança Pública de São Paulo deixa o cargo. G1. 21 nov. 2012. Disponível em: <http://g1.globo.com/sao-paulo/noticia/2012/11/secretario-de-segurancade-sao-paulo-deixa-o-cargo.html>. Acesso em: $15 \mathrm{dez} .2012$.

SHECAIRA, Sérgio Salomão. Criminologia. São Paulo: RT, 2004.

SHIMIZU, Bruno. Solidariedade e gregarismo nas facções criminosas: um estudo à luz da Psicologia das massas. São Paulo: IBCCRIM, 2011. (Monografias IBCCRIM n. 60).

SIFUSPESP cobra condições de trabalho e saúde ao secretário da Gestão Pública. SIFUSPESP. 12 dez. 2012. Disponível em: <http://www.sifuspesp.org.br/index.php/materia-4/1661.html>. Acesso em: 25 dez. 2012.

Subcomitê de Prevenção da Tortura e outros Tratamentos ou Penas Cruéis, DESUMANOS OU DEgRADANTES DA ONU. Relatório sobre a visita ao Brasil do Subcomitê de Prevenção da Tortura e outros Tratamentos ou Penas Cruéis, Desumanos ou Degradantes. Relatório Publicado em: fev. 2012. Disponível em: <www.onu.org.br/img/2012/07/relatorio_SPT_2012.pdf>. Acesso em: 17 jul. 2012.

SYKES, Gresham. The society of captives: a study of a maximum security prison. New Jersey: Princeton University Press, 1974.

TAETS, Adriana Rezende Faria. Abrindo e fechando celas: narrativas, experiências, e identidades de agentes de segurança penitenciária femininas. 2012. Dissertação (Mestrado em Antropologia Social) - Faculdade de Filosofia, Letras e Ciências Humanas, Universidade de São Paulo, São Paulo. 2012.

TEIXEIRA, Alessandra. Dispositivos de exceção e novas racionalidades do sistema punitivo: o surgimento do PCC e o modelo RDD. Perspectivas. Revista de Ciências Sociais da UNESP, v. 36, p. 175-208, 2009. Disponível em: <http://seer.fclar.unesp.br/perspectivas/search/results>. Acesso em: 25 dez. 2012.

. Prisões da exceção: Política penal e penitenciária no Brasil contemporâneo. 1 ed. Curitiba: Juruá Editora, 2009.

Thompson, Augusto. A questão penitenciária. 5 ed. Rio de Janeiro: Forense, 2002.

UniversidADE FEDERAL DE GoIÁs. Faculdade de Direito. Disponível em: <http://www.direito.ufg.br/pages/37266>. Acesso em: 21 dez. 2011.

VARELla, Drauzio. Carcereiros. 1 ed. São Paulo: Companhia das Letras, 2012. 
Venceslau, Paulo Marcelo. Grupo de Intervenção Rápida (GIR) do Sistema Penitenciário São Paulo. Praia Grande. 28 abr. 2009. Disponível em: <http://www2.forumseguranca.org.br/node/22592>. Acesso em: 28 dez. 2012.

YounG, Jock. A sociedade excludente. Rio de Janeiro: Revan, 2002. (Coleção Pensamento Criminológico v. 7). 


\section{CORREGEDORES PERMANENTES - 04.12.2012}

\section{VARAS DAS EXECUCCÕES CRIMINAIS - CAPITAL E INTERIOR}

\section{CAPITAL}

VARAS DAS EXECUCCÕES CRIMINAIS - CENTRAL (entrância final)

$1^{\text {a }}$ VARA DAS EXECUCÕ̃ES CRIMINAIS - CENTRAL (Res. 340/07) (final)

$\underline{2^{\mathrm{a}} \text { VARA DAS EXECUCÕES CRIMINAIS - CENTRAL (Res. 340/07) (final) }}$

3 $3^{\text {a } V A R A ~ D A S ~ E X E C U C C O ̃ E S ~ C R I M I N A I S ~-~ C E N T R A L ~(R e s . ~ 340 / 07) ~(f i n a l) ~}$

4 4 VARA DAS EXECUCÕ̃ES CRIMINAIS - CENTRAL (Res. 340/07) (final)

5a VARA DAS EXECUCÕ̃ES CRIMINAIS - CENTRAL (Res. 340/07) (final)

\section{INTERIOR}

\section{ARARAQUARA}

Vara do Júri e Execuções Criminais - (final 13ª CJ)

\section{OSASCO}

Vara do Júri e Execuções Criminais - ( final $\left.-4^{\mathrm{a}} \mathrm{CJ}\right)$

PIRACICABA

Vara do Júri e Execuções Criminais - (final $34^{\mathrm{a}} \mathrm{CJ}$ )

\section{RIBEIRÃO PRETO (}

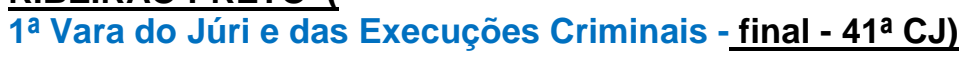

$2^{\mathrm{a}}$ Vara do Júri e das Execuções Criminais (Res. 298/07)(final - 41 ${ }^{\mathrm{a}} \mathrm{CJ}$ )

\section{SANTO ANDRÉ}

Vara do Júri e Execuções Criminais - (final $-3^{\mathrm{a}} \mathrm{CJ}$ )

SANTOS

Vara do Júri e Execuções Criminais - (final - $\mathbf{1}^{\mathrm{a}} \mathrm{CJ}$ ) 


\section{SÃO BERNARDO DO CAMPO)}

Vara do Júri e Execuções Criminais - $\underline{\left(\text { final }-2^{\mathrm{a}} \mathrm{CJ}\right.}$

\section{SÃO JOSÉ DOS CAMPOS}

Vara do Júri e Execuções Criminais - (final $-46^{\mathrm{a}} \mathrm{CJ}$ )

SOROCABA

Vara do Júri e Execuções Criminais - (final $-19^{\mathrm{a}} \mathrm{CJ}$ )

\section{AMERICANA}

Vara do Júri, Execuções Criminais e da Infância e da Juventude - (final - $53^{\mathrm{a}} \mathrm{CJ}$ )

BRAGANCA PAULISTA

Vara do Júri, Execuções Criminais e da Infância e da Juventude (Intermediária - $6^{\mathrm{a}} \mathrm{CJ}$ )

\section{FRANCA}

Vara do Júri, Execuções Criminais e da Infância e da Juventude (final - $\mathbf{3 8 ^ { \mathrm { a } } \mathrm { CJ } )}$

\section{FRANCO DA ROCHA}

Vara do Júri, Execuções Criminais e da Infância e da Juventude (intermediária - $5^{a} C J$ )

\section{JUNDIAÍ}

Vara do Júri, Execuções Criminais e da Infância e da Juventude (final - $5^{\mathrm{a}} \mathrm{CJ}$ )

\section{RIO CLARO}

Vara do Júri, das Execuções Criminais e da Infância e da Juventude (final - 9

\section{DIADEMA}

Vara do Júri, das Execuções Criminais, da Infância e da Juventude e do Idoso (final - $\mathbf{2}^{\mathrm{a}} \mathrm{CJ}$ )

\section{ARACATUBA}

$1^{\text {a }}$ Vara das Execuções Criminais(final $-36^{\mathrm{a}} \mathrm{CJ}$ )

$2^{\mathrm{a}}$ Vara das Execuções Criminais (Res. 266/06) (final - 36 $\mathrm{CJ}$ )

\section{BAURU}

$1^{a}$ Vara das Execuções Criminais (final $-32^{\mathrm{a}} \mathrm{CJ}$ )

$2^{\mathrm{a}}$ Vara das Execuções Criminais (Res. 264/06) (final - 32 ${ }^{\mathrm{a}} \mathrm{CJ}$ )

\section{CAMPINAS}

$1^{a}$ Vara das Execuções Criminais (final $-8^{\text {a }} \mathrm{CJ}$ )

$2^{\mathrm{a}}$ Vara das Execuções Criminais - Res. 263/06) (final - $8^{\mathrm{a}} \mathrm{CJ}$ )

\section{GUARULHOS}

Vara das Execuções Criminais (final $-44^{\mathrm{a}} \mathrm{CJ}$ )

\section{ITAPETININGA}

Vara das Execuções Criminais (final $-\mathbf{2 2}^{\mathrm{a}} \mathrm{CJ}$ )

\section{MARÍLIA}

Vara das Execuções Criminais (final $-3^{\mathrm{a}} \mathrm{CJ}$ )

\section{PRESIDENTE PRUDENTE}

$1^{a}$ Vara das Execuções Criminais (final $-27^{\mathrm{a}} \mathrm{CJ}$ )

$2^{\mathrm{a}}$ Vara das Execuções Criminais - Res. 265/06) (final - 27 ${ }^{\mathrm{a}} \mathrm{CJ}$ )

\section{SÃO JOSÉ DO RIO PRETO}

Vara das Execuções Criminais (final $-16^{\mathrm{a}} \mathrm{CJ}$ )

SÃO VICENTE

Vara das Execuções Criminais (final - $\mathbf{1}^{\mathrm{a}} \mathrm{CJ}$ ) 


\title{
TAUBATÉ
}

$1^{a}$ Vara das Execuções Criminais - (final $-47^{\mathrm{a}} \mathrm{CJ}$ )

$2^{\mathrm{a}}$ Vara das Execuções Criminais - (final $-47^{\mathrm{a}} \mathrm{CJ}$ )

TUPÃ

Vara das Execuções Criminais (Intermediária - 30 ${ }^{\mathrm{a}} \mathrm{CJ}$ )

$\underline{\text { INTERIOR (execuções - cumulativas) }}$

\section{ADAMANTINA \\ $1^{\text {a }}$ Vara \\ Execuções Criminais}

\author{
AMPARO \\ $1^{\text {a }}$ Vara \\ Execuções Criminais
}

\section{ANDRADINA}

$1^{\text {a }}$ Vara

Execuções Criminais

\section{APARECIDA}

$1^{\text {a }}$ Vara

Execuções Criminais

\section{Foro Distrital de Roseira}

Execuções Criminais

\section{Foro Distrital de Américo Brasiliense $\mathbf{1}^{\mathrm{a}}$ Vara \\ Execuções Criminais}

\section{ARARAS}

Vara Criminal

Execuções Criminais

\section{ASSIS}

\section{$1^{\text {a }}$ Vara Criminal}

Execuções Criminais

\section{ATIBAIA}

$\mathbf{3}^{\mathrm{a}}$ Vara Criminal

Execuções Criminais (inclusive, competência para conhecer e processar as Execuções Criminais com relação aos condenados provisórios e com condenação definitiva da Cadeia Pública de Bom Jesus dos Perdões)

\section{Foro Distrital de Jarinu}

Execuções Criminais

\section{AVARÉ}

$2^{\mathrm{a}}$ Vara Criminal

Execuções Criminais

Foro Distrital de Paranapanema

Execuções Criminais 


\section{BARRA BONITA}

$1^{\text {a }}$ Vara

Execuções Criminais

Polícia Judiciária e Presídios

(Cadeia Pública de Barra Bonita)

\section{BARRETOS}

\section{$1^{\text {a }}$ Vara Criminal}

Execuções Criminais

Polícia Judiciária e Presídios

(Cadeia Pública de Barretos)

\section{BARUERI}

$1^{\text {a }}$ Vara Criminal

Execuções Criminais

Polícia Judiciária e Presídio

\section{Foro Distrital de Jandira}

\section{$1^{\text {a }}$ Vara}

Execuções Criminais

Polícia Judiciária e Presídio

(Cadeia Pública de Jandira)

\section{BATATAIS}

Vara Criminal

Execuções Criminais

Polícia Judiciária e Presídios

(Cadeia Pública de Batatais)

\section{BEBEDOURO}

\section{$1^{a}$ Vara}

Execuções Criminais

Polícia Judiciária e Presídios

\section{BIRIGUI}

$1^{\text {a } \text { Vara Criminal }}$

Execuções Criminais

Polícia Judiciária e Presídios

(Centro de Ressocialização de Birigui)

\section{BOITUVA}

$1^{\text {a }}$ Vara

Execuções Criminais

Polícia Judiciária e Presídio

\section{BOTUCATU}

\section{$2^{\mathrm{a}}$ Vara Criminal}

Execuções Criminais

Polícia Judiciária e Presídios

Cadeia Pública de Botucatu

\section{Foro Distrital de Itatinga}

Execuções Criminais

Polícia Judiciária e Presídio 


\section{Foro Distrital de Pinhalzinho}

\section{Execuções Criminais}

\section{CACAPAVA}

$\mathbf{1}^{\text {a }}$ Vara

Execuções Criminais

Polícia Judiciária e Presídios

(Cadeia Pública Feminina de Caçapava)

\section{Foro Distrital de Paulínia}

$1^{a}$ Vara

Execuções Criminais

Polícia Judiciária e Presídio

\section{CAMPOS DO JORDÃO}

\section{$1^{a}$ Vara}

Execuções Criminais

Polícia Judiciária e Presídios

\section{CÂNDIDO MOTA}

$1^{\text {a }}$ Vara

Execuções Criminais

Cartório de Armas

Polícia Judiciária e Presídios

\section{CAPÃO BONITO}

\section{$1^{\text {a }}$ Vara}

Execuções Criminais

Polícia Judiciária e Presídios

(Cadeia Pública de Capão Bonito)

\section{CAPIVARI}

\section{$1^{\text {a }}$ Vara}

Execuções Criminais

Polícia Judiciária e Presídios

\section{CARAGUATATUBA}

\section{Vara Criminal}

Execuções Criminais

Polícia Judiciária e Presídios

(Centro de Detenção Provisória de Caraguatatuba, "Dr. José Eduardo Mariz de Oliveira")

\section{CARAPICUÍBA}

$2^{\text {a }}$ Vara Criminal

Execuções Criminais e Presídios

(Cadeia Pública de Carapicuíba)

Guarda de Armas

\section{CASA BRANCA}

\section{$1^{a}$ Vara}

Execuções Criminais

Polícia Judiciária e Presídios

(Penitenciária "Joaquim de Sylos Cintra" e Ala de Progressão) 
$1^{\text {a }}$ Vara Criminal

Execuções Criminais

Polícia Judiciária e Presídios

(Cadeia Pública de Catanduva)

\section{Foro Distrital de Tabapuã}

Execuções Criminais

Polícia Judiciária e Presidios

\section{CONCHAS}

$\mathbf{1}^{\mathrm{a}}$ Vara

Execuções Criminais

Polícia Judiciária e Presídios

(Cadeia Pública de Conchas)

\section{COTIA}

\section{Vara Criminal}

Execuções Criminais

Polícia Judiciária e Presídios

Foro Distrital de Vargem Grande Paulista

Execuções Criminais

Polícia Judiciária e Presídio

\section{CRAVINHOS}

$1^{\text {a }}$ Vara

Execuções Criminais

Polícia Judiciária e Presídios

\section{CRUZEIRO}

$\mathbf{2}^{\mathrm{a}}$ Vara

Execuções Criminais

Polícia Judiciária e Presídios

(Cadeia Pública de Cruzeiro)

\section{CUBATÃO}

\section{$\mathbf{1}^{\mathrm{a}}$ Vara}

Execuções Criminais

Polícia Judiciária e Presídios

\section{DESCALVADO}

$1^{\mathrm{a}}$ Vara

Execuções Criminais

Polícia Judiciária e Presídios

\section{DRACENA}

$\mathbf{1}^{\mathrm{a}}$ Vara

Execuções Criminais

Polícia Judiciária e Presídios (Penitenciária de Dracena)

(Cadeia Pública de Dracena)

\section{EMBU DAS ARTES}

$1^{a}$ Vara

Execuções Criminais

Polícia Judiciária e Presídio 
$1^{\text {a }}$ Vara

Execuções Criminais

Polícia Judiciária e Presídios

\section{FERNANDÓPOLIS}

$2^{\text {a }}$ Vara Criminal

Execuções Criminais

Polícia Judiciária e Presídios (inclusive Cadeias Públicas de Indiaporã, Guarani D’Oeste e Meridiano)

\section{FRANCISCO MORATO}

$1^{\mathrm{a}}$ Vara

Execuções Criminais

Polícia Judiciária e Presídio

\section{Foro Distrital de Caieiras}

$1^{\text {a }}$ Vara

Execução Criminal e Polícia Judiciária

\section{GARÇA}

$1^{\text {a }}$ Vara

Execuções Criminais

Polícia Judiciária e Presídios

(Cadeia Pública de Garça)

\section{GUARARAPES}

$1^{a}$ Vara

Execuções Criminais

Polícia Judiciária e Presídios

\section{GUARATINGUETÁ}

$\mathbf{2}^{\mathrm{a}}$ Vara

Execuções Criminais

Polícia Judiciária e Presídios

(Cadeia Pública de Guaratinguetá)

\section{GUARUJÁ}

$1^{\text {a }}$ Vara Criminal

Execuções Criminais

Polícia Judiciária e Presídios

)

\section{IBITINGA}

Vara Criminal

Execuções Criminais

Polícia Judiciária e Presídios

\section{IBIÚNA}

$\mathbf{1}^{\mathrm{a}}$ Vara

Execuções Criminais

Polícia Judiciária e Presídios

\section{IGARAPAVA}

$1^{a}$ Vara

Execuções Criminais

Polícia Judiciária e Presídios 
Cadeia Pública de Igarapava

\section{IGUAPE}

$1^{\text {a }}$ Vara

Júri

Execuções Criminais

Polícia Judiciária e Presídios

\section{INDAIATUBA}

$2^{\mathrm{a}}$ Vara Criminal

Execuções Criminais

Polícia Judiciária e Presídios

\section{ITANHAÉM}

\section{$2^{\mathbf{a}}$ Vara}

Execuções Criminais

Polícia Judiciária e Presídio

(Centro de Progressão Penitenciário "Dr. Rubens Aleixo Sendin”, de Mongaguá)

\section{Foro Distrital de Itariri}

Execuções Criminais

Polícia Judiciária de Pedro de Toledo e de Itariri

\section{ITAPECERICA DA SERRA}

\section{$4^{\mathrm{a}}$ Vara}

Execuções Criminais

Polícia Judiciária e Presídios

(Centro de Detenção Provisória de Itapecerica da Serra, "Asp. Nilton Celestino")

\section{Foro Distrital de Embu-Guaçu}

Execuções Criminais

Polícia Judiciária e Presídio

\section{ITAPEVA}

\section{$1^{a}$ Vara}

Execuções Criminais (inclusive, competência para conhecer e processar as Execuções Criminais com relação aos condenados provisórios e com condenação definitiva da Cadeia Pública de Buri)

Polícia Judiciária e Presídios

(Cadeia Pública de Itapeva)

\section{Foro Distrital de Itaberá}

Execuções Criminais

Polícia Judiciária e Presídio

\section{ITAPEVI}

\section{Vara Criminal}

Execuções Criminais

Polícia Judiciária e dos Presídios

\section{ITAPIRA}




\section{$1^{\text {a }}$ Vara}

Execuções Criminais

Polícia Judiciária e Presídios

(Unidade de Detenção, Triagem e Encaminhamento - UDTE, de Itapira)

\section{ITÁPOLIS}

\section{$1^{\text {a }}$ Vara}

Execuções Criminais

Polícia Judiciária e Presídios

\section{ITAQUAQUECETUBA}

$1^{a}$ Vara Criminal

Execuções Criminais

Polícia Judiciária e Presídios

(Cadeia Pública de Itaquaquecetuba)

\section{ITARARÉ}

\section{$1^{a}$ Vara}

Execuções Criminais

Polícia Judiciária e Presídios

(Cadeia Pública de Itararé)

\section{ITATIBA}

\section{Vara Criminal}

Execuções Criminais

Polícia Judiciária e Presídios

\section{ITU}

\section{$\mathbf{2}^{\mathrm{a}}$ Vara Criminal}

Execuções Criminais

Polícia Judiciária e Presídios

\section{ITUVERAVA}

$1^{\text {a }}$ Vara

Execuções Criminais

Polícia Judiciária e Presídios

\section{JABOTICABAL}

$2^{a}$ Vara

Execuções Criminais

Polícia Judiciária e Presídios

(Cadeia Pública de Jaboticabal)

\section{JACAREÍ}

\section{$\mathbf{1}^{\text {a }}$ Vara Criminal}

Execuções Criminais

Polícia Judiciária e Presídios

(Cadeia Pública de Jacareí)

\section{JACUPIRANGA}

$\mathbf{1}^{\mathrm{a}}$ Vara

Execuções Criminais

Polícia Judiciária e Presídios 


\section{Foro Distrital de Pariquera-Açu}

Execuções Criminais

Polícia Judiciária e Presídio

(Cadeia Pública Feminina de Pariquera-Açu)

\section{JAGUARIÚNA}

$1^{a}$ Vara

Execuções Criminais

Polícia Judiciária e dos Presídios de Jaguariúna

\section{JALES}

$2^{\text {a }}$ Vara

Execuções Criminais

Polícia Judiciária e Presídios

(Cadeia Pública de Jales)

\section{JARDINÓPOLIS}

$1^{a}$ Vara

Execuções Criminais

\section{JAÚ}

$1^{a}$ Vara Criminal

Execuções Criminais

Polícia Judiciária e Presídios

(Centro de Ressocialização de Jaú)

\section{JOSÉ BONIFÁCIO \\ $1^{a}$ Vara \\ Execuções Criminais \\ Polícia Judiciária e Presídios}

\section{Foro Distrital de Cajamar}

Execuções Criminais

Polícia Judiciária e Presídio

\section{Foro Distrital de Campo Limpo Paulista}

\section{$1^{\text {a }}$ Vara}

Execuções Criminais

Polícia Judiciária e Presídio

\section{LEME}

$1^{\text {a }}$ Vara

Execuções Criminais

Polícia Judiciária e Presídios

(Cadeia Pública de Leme)

\section{LENCÓIS PAULISTA}

\section{$1^{a}$ Vara}

Execuções Criminais

Polícia Judiciária e Presídios

Setor das Execuções Fiscais

\section{LIMEIRA}




\section{$2^{\text {a }}$ Vara Criminal}

Execuções Criminais

Polícia Judiciária e Presídios

(Centro de Ressocialização de Limeira)

\section{LINS}

$1^{\text {a }}$ Vara Criminal

Execuções Criminais

Polícia Judiciária e Presídios

(Centro de Ressocialização de Lins, "Dr. Manoel Carlos Muniz")

\section{LORENA}

$1^{\text {a }}$ Vara

Execuções Criminais

Polícia Judiciária e Presídios

\section{Foro Distrital de Piquete}

Execuções Criminais

Polícia Judiciária e Presídio

\section{MAIRIPORÃ}

\section{$1^{\text {a }}$ Vara}

Execuções Criminais

Polícia Judiciária e Presídios

(Cadeia Pública Feminina de Mairiporã)

\section{MATÃO}

\section{Vara Criminal}

Execuções Criminais

Polícia Judiciária e Presídios

\section{MAUÁ}

\section{$\mathbf{1}^{\mathrm{a}}$ Vara Criminal}

Infância e Juventude

(CASA - Centro de Atendimento Socioeducativo ao Adolescente de Mauá - CASA Mauá)

\section{$2^{\mathrm{a}}$ Vara Criminal}

Execuções Criminais

Polícia Judiciária e Presídios

(Centro de Detenção Provisória de Mauá)

\section{MIRACATU}

$1^{a}$ Vara

Execuções Criminais

Polícia Judiciária e Presídios

(Cadeia Pública de Miracatu)

\section{MIRANDÓPOLIS}

\section{$1^{a}$ Vara}

Execuções Criminais

Polícia Judiciária e Presídios

\section{MIRASSOL}

\section{$1^{a}$ Vara}

Execuções Criminais 
Polícia Judiciária e Presídios

\section{Foro Distrital de Neves Paulista}

Execuções Criminais

Polícia Judiciária e Presídio

\section{MOCOCA}

$1^{\text {a }}$ Vara

Execuções Criminais

Polícia Judiciária e Presídios

(Centro de Ressocialização de Mococa)

\section{MOGI DAS CRUZES}

$1^{a}$ Vara Criminal

Execuções Criminais

Polícia Judiciária e Presídios

(Cadeia Pública de Mogi das Cruzes)

(Centro de Detenção Provisória de Mogi das Cruzes)

\section{Foro Distrital de Brás Cubas}

\section{$1^{\text {a }}$ Vara}

Execuções Criminais

Polícia Judiciária e Presídio

\section{Foro Distrital de Guararema}

Execuções Criminais

Polícia Judiciária e Presídio

Criminal

\section{MOGI GUACU}

Vara Criminal

Execuções Criminais

Polícia Judiciária e Presídios

\section{MOJI MIRIM}

$2^{\text {a }}$ Vara

Execuções Criminais

Polícia Judiciária e Presídios

(Centro de Resssocialização de Moji Mirim, "Prof. João Missaglia")

MONGAGUÁ

$1^{\text {a }}$ Vara

Execuções Criminais

Polícia Judiciária e Presídio

\section{MONTE ALTO}

$3^{\text {a }}$ Vara

Execuções Criminais

\section{MONTE APRAZÍVEL}

\section{$1^{\text {a }}$ Vara}

Execuções Criminais

Polícia Judiciária e Presídios 
Foro Distrital de Macaubal

Polícia Judiciária e Presídio

\section{MONTE MOR}

$\mathbf{1}^{\mathrm{a}}$ Vara

Execuções Criminais

Polícia Judiciária e Presídios

\section{NOVO HORIZONTE}

\section{$1^{\text {a }}$ Vara}

Execuções Criminais

Polícia Judiciária e Presídios

(Cadeia Pública de Novo Horizonte)

\section{Foro Distrital de Itajobi}

Execuções Criminais

Polícia Judiciária e Presídio

\section{OLÍMPIA}

$\mathbf{1}^{\mathrm{a}}$ Vara

Execuções Criminais

Polícia Judiciária e Presídios

(Cadeia Pública de Altair)

\section{ORLÂNDIA}

$\mathbf{1}^{\mathrm{a}}$ Vara

Execuções Criminais

Polícia Judiciária e Presídios

\section{OSVALDO CRUZ}

\section{$\mathbf{1}^{\mathrm{a}}$ Vara}

Execuções Criminais

Polícia Judiciária e Presídios

\section{OURINHOS}

$1^{a}$ Vara Criminal

Execuções Criminais

Polícia Judiciária e Presídios

(Centro de Ressocialização de Ourinhos)

PALMITAL

\section{$\mathbf{1}^{\mathrm{a}}$ Vara}

Execuções Criminais

Polícia Judiciária e Presídios

\section{PARAGUACU PAULISTA}

$\mathbf{1}^{\mathrm{a}}$ Vara

Execuções Criminais

Polícia Judiciária e Presídios

(Cadeia Pública Feminina de Lutécia)

\section{PEDERNEIRAS}

\section{$1^{\text {a }}$ Vara}

Execuções Criminais 
Polícia Judiciária e Presídios

\section{PEDREIRA}

\section{$1^{a}$ Vara}

Execuções Criminais

Polícia Judiciária e Presídio

\section{PENÁPOLIS}

\section{$3^{\text {a }}$ Vara}

Execuções Criminais

Polícia Judiciária e Presídios

(Cadeia Pública de Penápolis)

\section{PEREIRA BARRETO}

\section{$1^{a}$ Vara}

Execuções Criminais

Polícia Judiciária e Presídios

\section{PERUÍBE}

\section{$1^{a}$ Vara}

Execuções Criminais

Polícia Judiciária e Presídio

(Cadeia Pública de Peruíbe)

\section{PIEDADE}

$1^{a}$ Vara

Execuções Criminais

Polícia Judiciária e Presídios

\section{PINDAMONHANGABA}

\section{Vara Criminal}

Execuções Criminais

Polícia Judiciária e Presídios

(Cadeia Pública de Pindamonhangaba)

\section{PIRACAIA}

$1^{\text {a }}$ Vara

Execuções Criminais

Polícia Judiciária e Presídio

(Cadeia Pública de Piracaia)

\section{Foro Distrital de Rio das Pedras}

Execuções Criminais

Polícia Judiciária e Presídio

\section{PIRAJÚ}

$1^{\text {a }}$ Vara

Execuções Criminais

Polícia Judiciária e Presídios

(Cadeia Pública de Manduri)

(Cadeia Pública de Piraju)

(Cadeia Pública de Sarutaiá)

(Cadeia Pública de Tejupá)

\section{PIRAJUÍ}

$1^{\mathrm{a}}$ Vara 
Execuções Criminais

Polícia Judiciária e Presídios

\section{PIRASSUNUNGA}

\section{$1^{a}$ Vara}

Execuções Criminais

Polícia Judiciária e Presídios

(Cadeia Pública de Pirassununga)

\section{POÁ}

$1^{a}$ Vara Criminal

Execuções Criminais

Polícia Judiciária e Presídios

(Cadeia Pública Feminina de Poá)

\section{Foro Distrital de Ferraz de Vasconcelos}

\section{$1^{a}$ Vara}

Execuções Criminais

Polícia Judiciária e Presídios

(Cadeia Pública de Ferraz de Vasconcelos)

\section{PORTO FELIZ}

\section{$1^{a}$ Vara}

Execuções Criminais

Polícia Judiciária e Presídios

\section{PORTO FERREIRA}

\section{$1^{\text {a }}$ Vara}

Execuções Criminais

Polícia Judiciária e Presídios

\section{PRAIA GRANDE}

$2^{a}$ Vara Criminal

Execuções Criminais

Polícia Judiciária e Presídios

(Centro de Detenção Provisória de Praia Grande)

\section{PRESIDENTE EPITÁCIO}

\section{$1^{\text {a }}$ Vara}

Execuções Criminais

Polícia Judiciária e Presídio

\section{PRESIDENTE VENCESLAU}

\section{$2^{\text {a }}$ Vara}

Execuções Criminais

Polícia Judiciária e Presídios

\section{PROMISSÃO}

\section{$1^{a}$ Vara}

Execuções Criminais

Polícia Judiciária e Presídio 


\section{RANCHARIA}

$\mathbf{1}^{\mathrm{a}}$ Vara

Execuções Criminais

Polícia Judiciária e Presídios

\section{Foro Distrital de lepê}

Execuções Criminais

Polícia Judiciária e Presídio

\section{REGISTRO}

$\mathbf{1}^{\text {a } \text { Vara }}$

Execuções Criminais

Polícia Judiciária e Presídios

(Cadeia Pública de Sete Barras)

(Cadeia Pública de Registro)

\section{RIBEIRÃO PIRES}

\section{$2^{\mathrm{a}}$ Vara}

Execuções Criminais

Polícia Judiciária e Presídios

\section{Foro Distrital de Rio Grande da Serra}

Execuções Criminais

Polícia Judiciária e Presídio

Foro Distrital de Itirapina

Execuções Criminais

Polícia Judiciária e Presídio

\section{SALTO}

$3^{\text {a }}$ Vara

Execuções Criminais

Polícia Judiciária e Presídios

\section{SANTA BÁRBARA D'OESTE}

\section{$1^{a}$ Vara Criminal}

Execuções Criminais

Polícia Judiciária e Presídio

\section{SANTA BRANCA (VARA ÚNICA)}

\section{Sede}

Execuções Criminais

Polícia Judiciária e Presídios

(Cadeia Pública de Santa Branca)

\section{Foro Distrital de Salesópolis}

Execuções Criminais

Polícia Judiciária e Presídio

\section{SANTA CRUZ DO RIO PARDO}

\section{$3^{a}$ Vara}

Execuções Criminais

Polícia Judiciária e Presídios

\section{SANTA FÉ DO SUL}


SANTA ISABEL

$2^{a}$ Vara

Execuções Criminais

Polícia Judiciária e Presídios

\section{Foro Distrital de Arujá}

$2^{a}$ Vara

Execuções Criminais

Polícia Judiciária e Presídio

\section{Foro Distrital de Bertioga}

$\mathbf{1}^{\mathrm{a}}$ Vara

Execuções Criminais

Polícia Judiciária e Presídios

\section{SÃO CAETANO DO SUL}

$2^{a}$ Vara Criminal e de Crimes contra a Vida

Execuções Criminais

Polícia Judiciária e Presídios

(Cadeia Pública de São Caetano do Sul)

\section{SÃO CARLOS}

$3^{a}$ Vara Criminal

Execuções Criminais

Polícia Judiciária e Presídios

(Cadeia Pública de São Carlos)

\section{Foro Distrital de lbaté}

Execuções Criminais

Polícia Judiciária e Presídio

\section{SÃO JOÃO DA BOA VISTA}

Vara Criminal

Execuções Criminais

Polícia Judiciária e Presídios

(Cadeia Pública de Águas da Prata)

(Cadeia Pública de São João da Boa Vista)

\section{SÃO JOAQUIM DA BARRA}

\section{$1^{a}$ Vara}

Execuções Criminais

Polícia Judiciária e Presídios

(Cadeia Pública de São Joaquim da Barra)

\section{SÃO JOSÉ DO RIO PARDO}

\section{$1^{a}$ Vara}

Execuções Criminais

Polícia Judiciária e Presídios

\section{Foro Distrital de São Sebastião da Grama}

Execuções Criminais

Polícia Judiciária e Presídio

\section{SÃO MANUEL}

\section{$\mathbf{1}^{\mathrm{a}}$ Vara}

Execuções Criminais

Polícia Judiciária e Presídios 
(Cadeia Pública de São Manuel)

\author{
SÃO ROQUE \\ $\mathbf{1}^{\text {a } \text { Vara }}$ \\ Execuções Criminais \\ Polícia Judiciária e Presídios \\ (Cadeia Pública de São Roque)
}

\title{
SÃO SEBASTIÃO
}

Vara Criminal

Execuções Criminais

Polícia Judiciária e Presídios

\section{Foro Distrital de llhabela}

Execuções Criminais

Polícia Judiciária e Presídios

\section{SERRA NEGRA}

$1^{a}$ Vara

Execuções Criminais

Polícia Judiciária e Presídios

(Cadeia Pública de Serra Negra)

\section{SERTÃOZINHO}

\section{Vara Criminal}

Execuções Criminais

Polícia Judiciária e Presídios

\section{SOCORRO}

\section{$1^{a}$ Vara}

Execuções Criminais

Polícia Judiciária e Presídios

(Delegacia de Polícia Judiciária de Socorro)

\section{Foro Distrital de Salto de Pirapora}

Execuções Criminais e Polícia Judiciária

Polícia Judiciária e Presídio

\section{SUMARÉ}

$1^{a}$ Vara Criminal

Execuções Criminais

Polícia Judiciária e Cadeias Públicas

\section{SUZANO}

$2^{\mathrm{a}}$ Vara Criminal

Execuções Criminais

Polícia Judiciária e Presídios

Centro de Detenção Provisória

\section{TABOÃO DA SERRA}

Vara Criminal

Polícia Judiciária e Presídios

(Cadeia Pública do $1^{\circ}$ Distrito Policial de Taboão da Serra)

Setor de Armas e Objetos

Execuções Criminais 


\section{$1^{a}$ Vara}

Execuções Criminais

Polícia Judiciária e Presídio

\section{TAQUARITINGA}

$2^{\text {a }}$ Vara

Execuções Criminais

Polícia Judiciária e Presídios

(Cadeia Pública Feminina de Fernando Prestes)

(Cadeia Pública Feminina de Santa Ernestina)

\section{TATUÍ}

$\mathbf{1}^{\mathrm{a}}$ Vara Criminal

Execuções Criminais

(processamento e julgamento dos crimes comuns e do Júri)

Cartório de Armas

Polícia Judiciária (Rodízio Bienal instituído pelo Provimento CSM nº 1816/2010 - de 20/10/2012 até 20/10/2014)

Presídios

\section{TIETÊ}

\section{$1^{a}$ Vara}

Execuções Criminais

Polícia Judiciária e Presídios

\section{TREMEMBÉ}

\section{$1^{\text {a }}$ Vara}

Execuções Criminais

Polícia Judiciária

\section{Foro Distrital de Bastos}

Execuções Criminais

Polícia Judiciária e Presídio

\section{TUPI PAULISTA}

\section{$\mathbf{1}^{\mathrm{a}}$ Vara}

Execuções Criminais

Polícia Judiciária e Presídios

\section{UBATUBA}

$2^{\text {a }}$ Vara

Execuções Criminais

Polícia Judiciária e Presídios

(Cadeia Pública de Ubatuba)

\section{VALINHOS}

\section{$\mathbf{1}^{\mathrm{a}}$ Vara}

Execuções Criminais

Polícia Judiciária e Presídio

\section{VARGEM GRANDE DO SUL}

\section{$1^{a}$ Vara}

Execuções Criminais

Polícia Judiciária e Presídios

(Cadeia Pública de Vargem Grande do Sul)

\section{VÁRZEA PAULISTA}

$1^{a}$ Vara 
Execuções Criminais

Polícia Judiciária e Presídio

\section{VINHEDO}

$1^{\mathrm{a}}$ Vara

Execuções Criminais

Polícia Judiciária e Presídio

\section{VOTORANTIM}

Vara Criminal

Execuções Criminais

Polícia Judiciária e Presídio

(Cadeia Pública de Votorantim)

\section{VOTUPORANGA}

$4^{\mathrm{a}}$ Vara

Execuções Criminais

Polícia Judiciária e Presídios

(Cadeia Pública de Votuporanga) 
Prezado(a) Sr(a) Vivian Calderoni

A sua solicitação de acesso a documentos, dados e informações, de protocolo 40334122172, data 05/11/2012, FOI ATENDIDA.

Secretaria: Secretaria Estadual Da Administração Penitenciária

Órgão: Secretaria Estadual Da Administração Penitenciária

Forma do recebimento da resposta: Correspondência eletrônica (e-mail)

Solicitação:

Quantos Agentes de Segurança Penitenciária (ASPs) estão lotados em cada uma das 149 unidades prisionais do estado de São Paulo?

Resposta:

Abaixo demonstramos o padrão de lotação de Agentes de Segurança Penitenciária das 155 Unidades Prisionais desta Secretaria da Administração Penitenciária:

Unidade Prisional

(68)Penitenciária Masculino

(09)Penitenciária Feminino

(37)Centro de Detenção Provisória Masculino 165

(01)Centro de Detenção Provisória

Feminino

(11)Centro de Progressão Penitenciária

Masculino

180

(02)Centro de Progressão Penitenciária Feminino

180

(16)Centro de Ressocialização Masculino

024

(06)Centro deRessocializaçãoFeminino

024

(02) Hospital de Custódia e Tratamento

Psiquiátrico Masculino 
(03) Hospital de Custodia e Tratamento

Psiquiátrico Feminino

Total de ASPs : 23.559 